\title{
CLINICAL INVESTIGATIONS OF NOISE AUDIOMETRY
}

\author{
MINAMI NAKANO, M.D. \\ Department of Otorhinolaryngology, Faculty of Medicine, \\ University of Nagoya (Director: S. Goto, M.D.)
}

The purpose of this investigation is to research changes of pure tone threshold resulting from white noise exposure in order to differentiate the pathological lesion of perceptive deafness and to evaluate the clinical value of noise audiometry.

\section{Materials :}

Normal hearing subjects and conductive and perceptive deaf person; that is (1) conductive deafness with chronic otitis media, (2) inner ear deafness by acoustic trauma with positive recruitment phenomenon with loudness balance test, (3) presbycusis, and (4) socalled perceptive deafness.

Results :

The change of the pure tone threshold by white noise exposure was recorded as noise audiogram, which enabled us to differentiate two types. The first type was to represent changes of pure tone threshold by white noise exposure of $10,20,30,40,50$, and $60 \mathrm{~dB}$ above threshold of white noise and the second type was not to represent change of pure tone threshold until white noise intensity increases to a certain intensity.

As to the type of noise audiogram and the difference limen value which carried out at $20 \mathrm{~dB}$ and $30 \mathrm{~dB}$ above the threshold, no decrease of the difference limen was found in all cases of normal subject and conductive deaf person with chronic otitis media which showed the first type of noise audiogram. and of presbycusis which showed the first and the second type of noise audiogram. A maked decrease who evidence in almost cases of acoustic trauma which showed the second type of noise audiogram.

That is, in almost cases of the first type of noise audiogram, no decrease of the difference limen was found. In cases of the second type of noise audiogram, both decrease and no change of the difference limen was found.

As mentioned above, normal hearing and conductive deafness with chronic otitis media showed the first type of noise audiogram, and inner ear deafness by acoustic trauma shows the second type, presbycusis showed both types of noise audiogram. It is supposed that the first type of noise audiogram results from a lesion of retrolabyrinthine disorders and the second type results from a lesion of Corti's organ.

Furthermore, the second type of noise audiogram is occasionally found out in some cases of normal hearing subjects or no hearing loss frequencies which are adjacent to remarkable hearing loss frequencies.

This result is supposed to indicate to find out some of the latent hearing disorders which is perphaps appeared to manifest in future.

Finally, it is possible to conclude that noise audiometry is clinically applied to differential diagnosis of possible localization of lesion in perceptive deafness to a certain extent. 


\title{
NOISE AUDIOMETRY の臨床的研究
}

\author{
名古屋大学医学部耳鼻咽喉科学教室 (指尊 ; 後藤修二教授) \\ 中 野陽量
}

第 1 篇 雑音下聴力検查の検討

目次

第 1 章 緒

第 2 章 研究対象绖び怡查方法

第 1 筑 矿笵刘象

第 2 節 椮查方法

第3 章 研究成算

第 1 節 正常耳の成繦

第1項 White noise に上る純音䦚值の変化

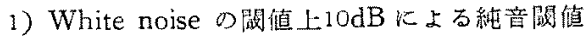
の然化

2) White noise $20 \mathrm{~dB}$ によ閔値の变化

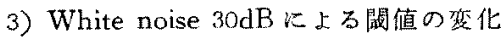

4) White noise $40 \mathrm{~dB}$ にる䦚值の变化

5) White noise $50 \mathrm{~dB}$ にる閶值の变化

6) White noise $60 \mathrm{~dB} \kappa 5 る$ 閶值の变化 小括

第 2 項 DL値

1) $1 \mathrm{KC} の \mathrm{DL}$ 值

2) $4 \mathrm{KC} の \mathrm{DL}$ 值

3) $\mathrm{DL}$ 值の左右耳の差

小括

第 2 節 伝音系難㯖耳の成紽

第 1 愐 White noise に上る純音闒値の疾化

第 2 項 DL 值

1) $1 \mathrm{KC}$ のL 值

2) $4 \mathrm{KC}$ のL 值

小括

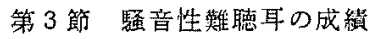

第、項 White noise に上る純音闘值の变化

第 2 項 最大間值周波数 ( $4 \mathrm{KC}$ ) 附近の周波数に 括けるWhite noise比よる閵优の变化

第 3 項 DI值

1) $1 \mathrm{KC} \odot \mathrm{DL}$ 值

2) $4 \mathrm{KC} の \mathrm{DL}$ 值
小括

第 4 節 老人性難德耳の成絰

第 1 項 White noise $心$ 万純音闒值の变化

第 2 項 闖值上年が高度の周波数附近の周波数に 和けるWhite noise による闘值の变化

第 3 項 DL 值

1) $1 \mathrm{KC} \sigma \mathrm{DL}$ 值

2) $4 \mathrm{KC}$ の DL 值

小括

第 4 章 総括並びに考按

第 5 章 結 語

泭 表

第 1 章 緒言

雑音を聴力検查に用いて純音閶值の変化を検查し，臨 休上種々の難聴の懢別診断に洒值があることを見出した のは Langenbeck"゙であ。

現在，雑音を用いる聴力検查法として，主に欧州で行 わ机ている方法は Langenbeck の “Geräusch Audiometrie" が代表的な検査法である.

Langenbeck は感覚レ心゙ルを用いるオージオメーター では “Geräuuch Audiometrie” の本質が失われるとして 各周波数で音圧を同じに出来るオージオメーターを使用 Lた.

しかしこの種の聴力梚查法を臨床上に用いるため に，私は今日臨床的に使用されているオージオメーター で，杂堷による純音間值の変化を検查し，その臨床的価 值について検討せんとした。

一方，感音雑聴耳の鑑別診断法の代表的方ものは Fowler の Balance Test であるが，この検查法は厳密 には一側耳の聴力が正常でなければならず，両側性の雑 聴には適用出来ず，この検查法が適用出来る範囲は可成 り限られている。この点を解決せんとして，一側の耳た けでも検查し得る方法が種々考按されてきた. DL Test もその一つである.この方法には Lüscher u. Zwislocki ${ }^{19)}$ 
のように閥值上の一点における DL 值を問題にする方法 と. Denes u. Naunton ${ }^{25)}$ のように關值上の二点におけ るDL 值を問題とする方法，あるいは Jerger'6) のよう に闒值上の二点における DL 值の差を問題にする方法等 があるが，いずれの方法におけるも測定方法が翼なる と，その值が異なるのは当然であるが，臨床上最も重要 である正常と病的との判定については, 必らずしも意見 は一致していない。

ここで，私は純音闒值上 $10 \mathrm{~dB}$ から60dB までの強さの White noiseによる純音閔値の変化と, 間值上10dB歹ら $60 \mathrm{~dB}$ における DL 值を検査して，乙の成績から，それ らの結果の判定法について考察を加え, White noiseに

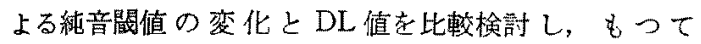
Noise Audiometry の臨床的価值とその限界を知らんと して検討を加えた。

\section{第 2 章 研究対象並びに研究方法}

\section{第 1 節 研究対象}

正常耳としては，耳鏡検查で外耳道及び战膜に異常所 見を認めず，純音オージオメーターによる気尊閶值が夫 々 $10 \mathrm{~dB}$ 以内の範围にあるもの25耳を対象とした。

病的耳としての第 1 群は，一般外来を訪れた難聴を訴 える患者のうち，既往厢，耳鏡所見及び純音オージオメ ーターによる聴力検查で, 慢性中耳炎と思われる20名21 耳の伝音系障害耳で, その年命, 性別, 経過期間及び純 音閶値は第 4 表 $(1 \sim 4)$ に示文ら万である。

第 2 群としては名古屋市内某金属工場の帡票員の中か ら Fowler 氏法による Binaural Loudness Balance Test 又は Reger 氏法に準ずる Monaural Loudness Balance Test で，Recruitment現象が陽性を示した18名32耳の騒 音性難㯖耳で, その年命, 性別, 経過期間及び純音闒值 は第 5 表 $(1 \sim 4)$ に示すよ5である.

第3群よしては古屋市内某老人ホームの老人で, 耳疾 患の既往歴のない14名28耳の老人性難聴耳で，その年 令, 性別, 経過期間及び純音閶值は第6表 $(1 \sim 3)$ に 亦すようである。

第 2 節 检查方法

検查住名古屋大学医学部耳鼻咽喉科学教室の防音室と

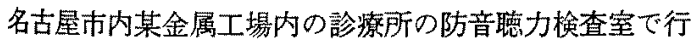
つた.

Noise Audiometryには小林理研製の 1013A (1002D) 型オージオメーター起使用した，検査方法は次の如くで ある

すなわち White noise による純音閥值の変化の検查
には，先づ各周波数の純音最小閔值庄上开法で求める。 次に White noise の出力ダイアルを OdB から $5 \mathrm{~dB}$ 宛移 動してWhite noise の強ささ增し, 初めてWhite noise の音を聴取し得た時のダイアル目盛 (dB数)を読み，こ の值を White noise の閶值とした.

次いで, White noise による純音間值の変化を求める ため，White noise の強さをその閵值上 $10 \mathrm{~dB}, 20 \mathrm{~dB}, 30$ $\mathrm{dB}, 40 \mathrm{~dB}, 50 \mathrm{~dB}, 60 \mathrm{~dB}$ とL, こ机らの各強さの White noise について，同一レシーバーに White noise と純音 を mix した状態で，純音の強さを最小間值から5dB宛 増し, White noise 中に初めて純音圭持続的に聴取し得 た時の純音の強さ ( $\mathrm{dB}$ 数) を各周波数について求めた。

しかして, White noise mix して変化した純音閔

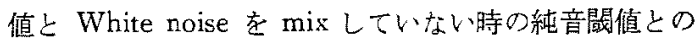
差が，White noiseによる純音閶值の変化の值である.

DL (Difference Limen for Loudness) Test 1 1KC, $4 \mathrm{KC}$ といて閶倠上 $10 \mathrm{~dB} .20 \mathrm{~dB}$. $30 \mathrm{~dB} .40 \mathrm{~dB} .50 \mathrm{~dB} .60$ $\mathrm{dB}$ (病的耳では測定可能範囲内) で行つた，脉音は每

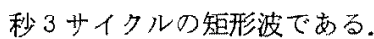

\section{第 3 章 研究 成 績}

第 1 節 正常耳の成績

第 1 項 White noise による純音闌值の变化

正常25耳について White noise $の$ 閥值上 $10 \mathrm{~dB}, 20$ $\mathrm{dB}, 30 \mathrm{~dB}, 40 \mathrm{~dB}, 50 \mathrm{~dB}, 60 \mathrm{~dB}$ の強さによ吕各周波数の 䦪傎の変化を検索した結果は，第1表 $(1 \sim 3)$ に示す 如くである。

1) White noise $\sigma$ 間值上 $10 \mathrm{~dB}$ (以下 White noise 何 $\mathrm{dB}$ と称す) による純音閧値の変化（以下闒值の変化 と記す)

$125 \mathrm{cps}$ では変化がなかつたもの17耳. $5 \mathrm{~dB}$ 変化したも の7耳. $10 \mathrm{~dB}$ 変化したもの1耳で，平均值は1.80dBで ある. 250cpsでは変化がなかつたもの10耳. $5 \mathrm{~dB}$ 変化し たもの15耳で，平均値は3.00dBである，500cpsでは变 化がなかつたもの11耳，5dB 変化したもの14耳で，平均 值は2.80 dBである.1000cps では変化がなかつたもの14 耳，5dB変化したもの9耳，10dB変化したもの2耳で, 平均值は2.60dBである、2000cpsでは变化がなかつたも の3耳，5dB変化したもの17耳，10dB変化したもの5耳 で，平均值は5.40dBである. 3000cps では5dB 変化した もの9耳, 10dB变化したもの11耳, $15 \mathrm{~dB}$ 変化したもの 5 耳で，平均值は9.20dBである。4000cpsで変化がな かつたもの2耳， $5 \mathrm{~dB}$ 変化したもの12耳， $10 \mathrm{~dB}$ 変化し たもの 7 耳, $15 \mathrm{~dB}$ 変化したもの 4 耳で, 平均值は7.60 
dBである。6000cpsでは变化がなかつたもの6耳，5dB 変化したもの8耳, $10 \mathrm{~dB}$ 变化したもの9耳, $15 \mathrm{~dB}$ 変化 したもの1耳，20dB变化したもの1耳で，平均值は6.60 dBである. $8000 \mathrm{cps}$ では変化がなかつたもの6耳，5dB 変化したむの13耳, $10 \mathrm{~dB}$ 変化したもの3耳, $15 \mathrm{~dB}$ 変化 したもの3耳で，平均值は5.60dBである。

2) White noise $20 \mathrm{~dB}$ にるる間值の変化

125cpsでは变化がなかつたもの13耳，5dB変化したも の10耳, $10 \mathrm{~dB}$ 変化したもの1耳, $15 \mathrm{~dB}$ 変化したもの1 耳で，平均值は3.00dBである，250cps では変化がなか つたもの11耳で, $5 \mathrm{~dB}$ 変化したもの13耳，10dB変化し たもの 1 耳で, 平均值は3.00dBである. $500 \mathrm{cps}$ では変 化がなかつたの12耳， $5 \mathrm{~dB}$ 変化したもの12耳，10dB 変化したもの1耳，平均值は $2.80 \mathrm{~dB}$ である，1000 cpsで は変化がなかつたもの3耳, $5 \mathrm{~dB}$ 変化したもの10耳，10 dB変化したもの10耳, 15dB変化したもの1耳, $20 \mathrm{~dB}$ 変 化したもの1耳で, 平均值は7.40dBである.2000cpsで は変化がなかつたもの1耳，5dB変化したもの3耳，10 $\mathrm{dB}$ 変化したもの12耳，15dB変化したもの8耳，20dB変 化したもの1耳で, 平均值は $11.00 \mathrm{~dB}$ である。 $3000 \mathrm{cps}$ では10dB変化したもの 7 耳， $15 \mathrm{~dB}$ 変化したもの9耳, $20 \mathrm{~dB}$ 変化したもの9耳で，平均值は15.40dBである。 $4000 \mathrm{cps}$ では $5 \mathrm{~dB}$ 変化したもの3耳, $10 \mathrm{~dB}$ 変化したもの $11 耳, 15 \mathrm{~dB}$ 変化したもの6耳，20dB変化したもの3耳 $25 \mathrm{~dB}$ 変化したもの1耳，30dB变化した8の1耳で，平 均倠は 13. $20 \mathrm{~dB}$ で西る。 $6000 \mathrm{cps}$ では $5 \mathrm{~dB}$ 変化したもの 2 耳, $10 \mathrm{~dB}$ 変化したもの10耳, $15 \mathrm{~dB}$ 変化したもの 8 耳, $20 \mathrm{~dB}$ 変化したもの 4 耳, $35 \mathrm{~dB}$ 変化したすの 1 耳で, 平 均值は $13.80 \mathrm{~dB}$ である，8000cpsでは変化がなかつたも の 4 耳, $5 \mathrm{~dB}$ 変化したもの 7 耳, $10 \mathrm{~dB}$ 変化したもの8耳 $15 \mathrm{~dB}$ 変化したもの 4 耳, $20 \mathrm{~dB}$ 変化したもの1耳, $25 \mathrm{~dB}$ 変化したもの1耳で, 平均値仿8. $80 \mathrm{~dB}$ である.

3) White noise $30 \mathrm{~dB}$ による閥值の変化

$125 \mathrm{cps}$ では変化がなかつたもの9耳，5dB変化したも の7耳, $10 \mathrm{~dB}$ 变化したもの7耳, $15 \mathrm{~dB}$ 変化したもの 1 耳，20dB变化したもの1耳で，平均値は5.60dBである。 $250 \mathrm{cps}$ では変化がなかつたの 10 耳， $5 \mathrm{~dB}$ 変化したもの

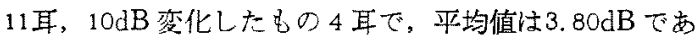
る. $500 \mathrm{cps}$ で5dB変化したもの10耳， $10 \mathrm{~dB}$ 変化した もの8耳，15dB変化したもの7耳で，平均值は9. $40 \mathrm{~dB}$ である. $1000 \mathrm{cps}$ で士5dB変化したもの1耳，10dB変化 したもの7耳, $15 \mathrm{~dB}$ 変化したもの12耳, $20 \mathrm{~dB}$ 変化した むの 4 耳，30dB変化したもの1耳で，平均值は14.60dB
である. $2000 \mathrm{cps}$ したもの 2 耳, $15 \mathrm{~dB}$ 変化したもの3耳, $20 \mathrm{~dB}$ 変化した むの14耳, $25 \mathrm{~dB}$ 变化したもの3耳, $30 \mathrm{~dB}$ 変化したもの 1 耳で，平均值讷 $18.40 \mathrm{~dB}$ である. $3000 \mathrm{cps}$ では15dB変 化したもの3耳，20dB変化したもの6耳，25dB変化し たもの9耳，30dB変化したもの7耳で，平均值は24.00 $\mathrm{dB}$ である，4000 cps では $5 \mathrm{~dB}$ 変化したもの 1 耳, $10 \mathrm{~dB}$ 変化したもの2耳，15dB変化したもの1耳，20dB変化 したもの12耳, $25 \mathrm{~dB}$ 変化したもの3耳, $30 \mathrm{~dB}$ 変化した もの 3 耳, $35 \mathrm{~dB}$ 変化したもの 3 耳で, 平均值は $23.00 \mathrm{~dB}$ である、6000cpsでは10dB变化したもの1耳，15dB変化 したもの6耳, $20 \mathrm{~dB}$ 変化したもの10耳, 25dB 変化した もの 5 耳, $30 \mathrm{~dB}$ 変化したもの 2 耳, $35 \mathrm{~dB}$ 変化したもの 1 耳で, 平均值は20.80dBである。 $8000 \mathrm{cps}$ では $5 \mathrm{~dB}$ 変 化したもの 2 耳, $10 \mathrm{~dB}$ 変化したもの 5 耳, $15 \mathrm{~dB}$ 変化し たもの11耳, $20 \mathrm{~dB}$ 変化したもの 4 耳, $25 \mathrm{~dB}$ 変化したも の2耳, $30 \mathrm{~dB}$ 変化したもの1耳で, 平均值は $15.40 \mathrm{~dB}$ である。

4) White noise $40 \mathrm{~dB}$ による闌值の変化

$125 \mathrm{cps}$ では変化がなかつたもの 4 耳，5dB変化したも の 5 耳, $10 \mathrm{~dB}$ 変化したもの10耳, $15 \mathrm{~dB}$ 変化したもの3 耳，20dB変化したもの 2 耳，25dB変化したもの1耳で, 平均值は9. $40 \mathrm{~dB}$ である. $250 \mathrm{cps}$ で注変化がなかつたも の 3 耳, $5 \mathrm{~dB}$ 変化したもの 7 耳, $10 \mathrm{~dB}$ 変化したもの14耳, $15 \mathrm{~dB}$ 変化したもの1耳で，平均值は7.60dBである。 500 cpsでは5dB変化したものI耳, $10 \mathrm{~dB}$ 変化したもの3耳, $15 \mathrm{~dB}$ 変化したもの6耳, $20 \mathrm{~dB}$ 変化したもの 7 耳, $25 \mathrm{~dB}$ 変化したもの8 耳で, 平均值は18.60dBである.1000 cps では15dB変化したもの4耳，20dB変化したもの3耳， $25 \mathrm{~dB}$ 変化したもの12耳, $30 \mathrm{~dB}$ 変化したもの 5 耳, $35 \mathrm{~dB}$ 変化したもの 1 耳で, 平均值は24.20dBである。2000 cps では $15 \mathrm{~dB}$ 変化したもの1耳，20dB変化したもの1耳， $25 \mathrm{~dB}$ 変化したもの10耳, 30dB変化したもの7耳, $35 \mathrm{~dB}$ 変化したもの 5 耳， $40 \mathrm{~dB}$ 変化したもの1耳で，平均值 は28.40dBである。3000cpsでは25dB変化したもの2耳， 30dB変化したもの9耳, $35 \mathrm{~dB}$ 変化したもの10耳, $40 \mathrm{~dB}$ 変化したもの 4 耳で，平均值は33.20dBである.4000cps では20dB変化したもの 1 耳，25dB変化したもの3耳， $30 \mathrm{~dB}$ 変化したもの11耳, $35 \mathrm{~dB}$ 変化したもの5耳，40dB 変化したもの3耳， $45 \mathrm{~dB}$ 変化したもの2耳で，平均值 は32.40dBである。6000cpsでは25dB変化したもの4耳， $30 \mathrm{~dB}$ 変化したもの10耳, $35 \mathrm{~dB}$ 栾化したもの5耳, $40 \mathrm{~dB}$ 変化したもの4耳，45dB 変化したもの1耳，50dB変化 
したもの1耳で，平均值は33.20dBである。 $8000 \mathrm{cps}$ 估15dB 変化したもの1耳, $20 \mathrm{~dB}$ 变化したもの6耳, 25 $\mathrm{dB}$ 変化したもの6耳, $30 \mathrm{~dB}$ 变化したもの 7 耳, $35 \mathrm{~dB}$ 変 化したもの3耳，45dB変化したもの2耳で，平均值は 27. $20 \mathrm{~dB}$ である.

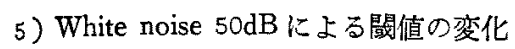

$125 \mathrm{cps}$ で $5 \mathrm{~dB}$ 変化したもの6耳, 10dB変化したもの 8 耳, $15 \mathrm{~dB}$ 変化したもの7耳, $20 \mathrm{~dB}$ 変化したもの2耳, $25 \mathrm{~dB}$ 変化したもの2耳で, 平均值は12.20dBである. 250cpsでは5dB変化したもの1耳, 10dB変化したもの9 耳, $15 \mathrm{~dB}$ 変化したもの11耳, $20 \mathrm{~dB}$ 変化したもの 3 耳, $25 \mathrm{~dB}$ 变化したもの1耳で，平均値は13.80dBである。 $500 \mathrm{cps}$ では15dB 変化したもの1耳, $20 \mathrm{~dB}$ 変化したもの 4 耳, 25dB変化したもの 4 耳, 30dB変化したもの8耳, $35 \mathrm{~dB}$ 変化したもの8耳で, 平均值は $28.00 \mathrm{~dB}$ である。 $1000 \mathrm{cps}$ では25dB 変化したもの3耳，30dB変化したも の6耳, 35dB変化したもの9耳, 40dB変化したもの6 耳, $45 \mathrm{~dB}$ 変化したもの 1 耳で, 平均值は34. $20 \mathrm{~dB}$ であ ろ. $2000 \mathrm{cps}$ では25dB変化したもの1耳, 30dB変化した もの1耳, $35 \mathrm{~dB}$ 変化したもの5耳, $40 \mathrm{~dB}$ 変化したもの 11 耳, $45 \mathrm{~dB}$ 変化したもの 5 耳, $50 \mathrm{~dB}$ 変化したもの 2 耳 で, 平均值は39.80dBである。 $3000 \mathrm{cps}$ では $35 \mathrm{~dB}$ 変化し たもの 5 耳, $40 \mathrm{~dB}$ 変化したもの 5 耳, $45 \mathrm{~dB}$ 変化したも の7耳, 50dB変化したもの8耳で, 平均值は43,60dBで ある，4000cpsでは35dB変化したもの6耳，40dB変化し たもの8耳，45dB変化したもの3耳，50dB変化したも 96耳, $55 \mathrm{~dB}$ 変化したもの 2 耳で, 平均值は43.00dBで ある. $6000 \mathrm{cps}$ たもの2耳, $40 \mathrm{~dB}$ 変化したもの13耳, $45 \mathrm{~dB}$ 変化したも の耳, $50 \mathrm{~dB}$ 変化したもの3耳, $55 \mathrm{~dB}$ 変化したもの 2 耳で，平均值は43.40dBである. $8000 \mathrm{cps}$ では $20 \mathrm{~dB}$ 変化 したもの1耳, $30 \mathrm{~dB}$ 変化したもの 4 耳, $35 \mathrm{~dB}$ 変化した 6の6耳, $40 \mathrm{~dB}$ 変化したもの7耳，45dB 変化したもの 7 耳で，平均値は37. $80 \mathrm{~dB}$ である。

6) White noise $60 \mathrm{~dB}$ にる閏値の変化

$125 \mathrm{cps}$ では $5 \mathrm{~dB}$ 変化したもの1耳, $10 \mathrm{~dB}$ 変化したもの 8耳, $15 \mathrm{~dB}$ 変化したもの11耳, 20dB变化したもの1耳, 25dB変化したもの3耳, $40 \mathrm{~dB}$ 変化したもの1耳で，平 均值は15.40dBである. $250 \mathrm{cps}$ では15dB変化したもの 4 耳, $20 \mathrm{~dB}$ 変化したもの11耳, $25 \mathrm{~dB}$ 変化したもの8耳, $30 \mathrm{~dB}$ 変化したもの1耳，35dB 変化したもの1耳で，平 均稹は21.80dBである. $500 \mathrm{cps} ゙$ は25dB変化したもの1 耳, $30 \mathrm{~dB}$ 変化したもの3耳, $35 \mathrm{~dB}$ 変化したもの3耳,
$40 \mathrm{~dB}$ 変化したもの13耳，45dB変化したもの5耳で，平 均值は $38.60 \mathrm{~dB}$ でる。 $1000 \mathrm{cps}$ で壮 $35 \mathrm{~dB}$ 変化したもの 3耳，40dB変化したもの2耳，45dB変化したもの11耳， $50 \mathrm{~dB}$ 変化したもの7 F, $55 \mathrm{~dB}$ 変化したもの 2 耳で, 平 均值は45.60dBでする。. $2000 \mathrm{cps}$ では25dB変化したもの 1 耳, $40 \mathrm{~dB}$ 変化したもの 2 耳, $45 \mathrm{~dB}$ 変化したもの 4 耳, $50 \mathrm{~dB}$ 変化した日の6耳, $55 \mathrm{~dB}$ 変化した日の10耳, $60 \mathrm{~dB}$ 変化したもの1耳，65dB変化したもの1耳で，平均值 は50.40dBである。3000 cpsでは45dB変化したもの4耳, $50 \mathrm{~dB}$ 変化したもの2耳, $55 \mathrm{~dB}$ 変化したもの9耳, $60 \mathrm{~dB}$ 変化したもの9耳, $65 \mathrm{~dB}$ 変化したもの1耳で, 平均值 は55.20dBである.4000cpsでは40dB变化したもの1耳, $45 \mathrm{~dB}$ 変化したもの1耳, $50 \mathrm{~dB}$ 変化したもの5耳, $55 \mathrm{~dB}$ 変化したもの9耳, $60 \mathrm{~dB}$ 変化したもの4耳，65dB変化 したもの 4 耳， $70 \mathrm{~dB}$ 変化したもの1耳で，平均值は 56. $00 \mathrm{~dB}$ である。 $6000 \mathrm{cps}$ では45dB 変化したもの 4 耳, $50 \mathrm{~dB}$ 変化した8の5耳, $55 \mathrm{~dB}$ 変化したもの9耳, $60 \mathrm{~dB}$ 変化したもの5耳，65dB変化したもの1耳; $70 \mathrm{~dB}$ 変化 したもの1耳で，平均值は54.40dBである. $8000 \mathrm{cps}$ は30dB変化したもの1耳, $40 \mathrm{~dB}$ 変化したもの 2 耳, 45 $\mathrm{dB}$ 変化したもの5耳，50dB変化したもの9耳，55dB変 化したもの8耳で，平均值は49.00dBである;

小 括

正常耳に White noise の種々の強さを与をた㭙の純留 間值の平均を曲稳で示すと第 1 困のよらである。すなわ ち一般的には White noiseが大になると絈音閾值も大き くなつて，ほぼ平行線たどり，特に，中，高晋域でそ れが明らかである。

第1図正常耳の平均值

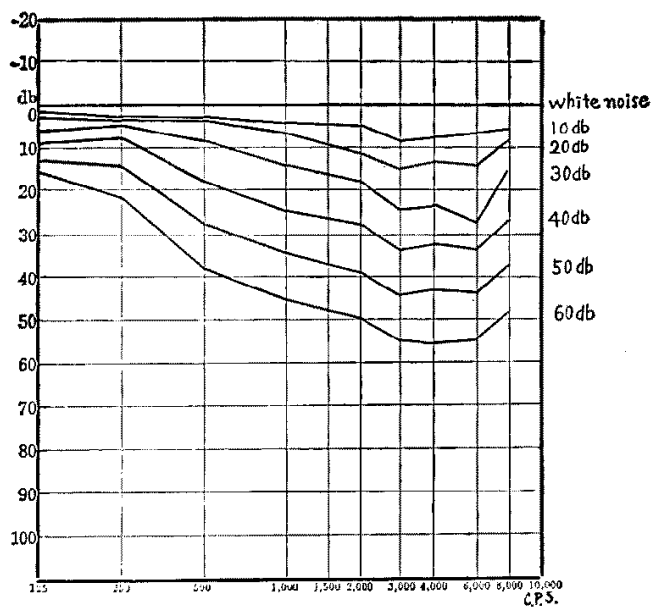


しかして，White noise 10dBでは0.5KCまでは5dB 以上変化したものはないが，1KC，2KCでは $10 \mathrm{~dB}$ 変化 したものがあり，3KC，4KC，8KCでは15dB変化した ものがあり，6KCでは $20 \mathrm{~dB}$ 衤化したものがある。しか して大きな変化走すものは1つの周波数のみのことは なく，2，3の周波数に及んでいる。

又, White noise $20 \mathrm{~dB}$ では0.5KC までは10dB 以上変 化したものはないが，1 $\mathrm{KC}, 2 \mathrm{KC}, 3 \mathrm{KC}$ では $20 \mathrm{~dB}$ 変化 したものがあり，4KC，8KCでは25dB変化したものがあ り，6KCでは $35 \mathrm{~dB}$ 変化したものがあり，しかして大き な変化を示すものは1つの周波数のみのことはなく，2 3の周波数に扔いて大きい，従つて，White noise 奂荷 による闒值の変化には個人差があり，個体に特性がある といらことになる。

White noise $30 \mathrm{~dB}$ では $1 \mathrm{KC}$ 以上の周波数では純音間 值は30dB〜35dBのものがあり, White noise $40 \mathrm{~dB} に な$ ると $2 \mathrm{KC}$ 以上の周波数では純音閶值は $40 \mathrm{~dB} \sim 50 \mathrm{~dB}$ にな るものが小なくない.

又, 一方 White noise 10dBによる純音閶値は White noise を加える前の純音間值しの閒に差のない周波数が 多いので,この White noise の強さは用い難い.これ に反して White noise $20 \mathrm{~dB} に よ る$ 純音閶值は $1 \mathrm{KC}$ 以 上の周波数では差のあるものが大部分である.

しかして，本研究の主目的である病的耳ではWhite noise 老負荷してない場合でも純音閥值なとなつてい るので，加え得る White noise の大きさには限度があ る.

徉つて，感音難聴耳をこの方法で検索するにはWhite noise としては30dBが許される最大であるといらことに なる。

第 2 項 DL 值

正常耳40耳の1KCと $4 \mathrm{KC} に$ 和ける閶值上 $10 \mathrm{~dB}$ 加 560 dBにおけるDL值を検查した成績は第 2 表に示す如くで ある。

1) $1 \mathrm{KC} の \mathrm{DL}$ 值

閧值上10dBでは0. $8 \mathrm{~dB} の も の$ 耳, $1.0 \mathrm{~dB} の も の 9$ 耳,

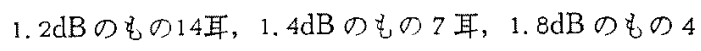
耳, $2.0 \mathrm{~dB} の$ ○耳である。

閾值上 $20 \mathrm{~dB}$ では0. $6 \mathrm{~dB} の も 3 耳, 0.8 \mathrm{~dB} の も \sigma$

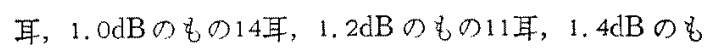

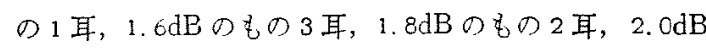
のもの1耳である。

閔值上 $30 \mathrm{~dB}$ では0. $4 \mathrm{~dB} の も の 1$ 耳, $0.6 \mathrm{~dB} の も の 6$
耳, $0.8 \mathrm{~dB} の も 014$ 耳, $1.0 \mathrm{~dB} の も 013 耳, 1.2 \mathrm{~dB} の$ の3耳, $1.4 \mathrm{~dB} の$ の耳, $1.6 \mathrm{~dB}$ のも 1 耳である.

䦨值上 $40 \mathrm{~dB}$ では0. $4 \mathrm{~dB} の も の 3 耳, 0.6 \mathrm{~dB}$ のもの13 耳, $0.8 \mathrm{~dB} \sigma$ \& 19 耳, $1.0 \mathrm{~dB} \sigma 803$ 耳, $1.2 \mathrm{~dB} \sigma$ \& の 2 耳である.

閶值上 $50 \mathrm{~dB}$ では0. $4 \mathrm{~dB} の \& の 7 耳, 0.6 \mathrm{~dB} の も 21$ 耳, $0.8 \mathrm{~dB} の も の 7$ 耳, $1.0 \mathrm{~dB}$ のの 4 耳, $1.2 \mathrm{~dB}, \sigma も$ の 1 耳である:

闇值上 $60 \mathrm{~dB}$ で注0. $4 \mathrm{~dB}$ の $012 耳, 0.6 \mathrm{~dB}$ のもの22 耳, $0.8 \mathrm{~dB}$ のも3耳, $1.0 \mathrm{~dB} の も の$ 耳である.

\section{第 2 図}

症例番号 No. 23

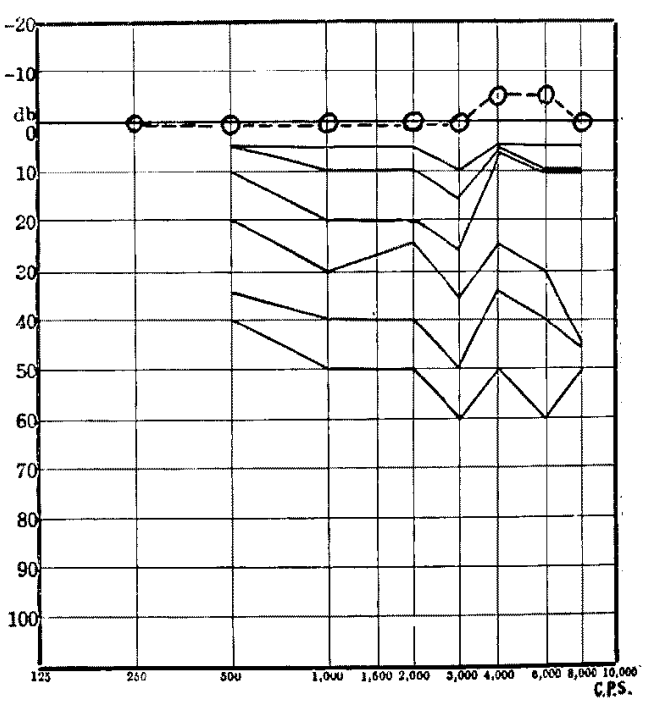

2) $4 \mathrm{KC}$ の DL 值

閶值上 $10 \mathrm{~dB}$ では $0.6 \mathrm{~dB} の も の 3$ 耳, $0.8 \mathrm{~dB}$ のの 11 耳, $1.0 \mathrm{~dB} の \& 014$ 耳, $1.2 \mathrm{~dB} \sigma も 010 耳, 1.4 \mathrm{~dB} \sigma$. の 2 耳である。

間值上 $20 \mathrm{~dB}$ では0. $6 \mathrm{~dB} の も の 6 耳 ， 0.8 \mathrm{~dB} の も の 19$ 耳, $1.0 \mathrm{~dB} \sigma も 011$ 耳, $1.2 \mathrm{~dB} \sigma も 03$ 耳, $1.4 \mathrm{~dB} \sigma$. の 1 耳である.

闒值上 $30 \mathrm{~dB}$ では $0.4 \mathrm{~dB}$ のの3耳, $0.6 \mathrm{~dB} の も の 15$ 耳, $0.8 \mathrm{~dB}$ もの18耳, $1.0 \mathrm{~dB} の も の$ 耳, $1.2 \mathrm{~dB} の も$. の 1 耳である.

閶值上 $40 \mathrm{~dB}$ では0. $4 \mathrm{~dB}$ のの11耳, $0.6 \mathrm{~dB} の も の 21$ 耳, $0.8 \mathrm{~dB}$ のの7耳, $1.0 \mathrm{~dB} の も 1$ 耳である。

闇值上 $50 \mathrm{~dB}$ では0. $4 \mathrm{~dB} の も の 22 耳 ， 0.6 \mathrm{~dB} の も の 1 ?$ 耳, $0.8 \mathrm{~dB}$ のも 1 耳である。 
闒值上60dBでは0. $4 \mathrm{~dB} の も 27$ 耳，0.6dBのもの13耳 である.

\section{3) DL 値の左右耳の差}

DL 值の左右耳の差は第 3 表に示寸如くである.

$1 \mathrm{KC}$ に括いて闒値上 $10 \mathrm{~dB}$ では差のないもの6 例, 差 が0. $2 \mathrm{~dB}$ のもの10例，差が0. $4 \mathrm{~dB} の も の 2$ 例，差が0.6 dBのもの1 例, 差が1.OdBのもの1例である.

閵上20dBでは差のないもの6例，差が0.2dBのもの 5 例, 差が0. $4 \mathrm{~dB}$ のも 7 例, 差が0. $6 \mathrm{~dB}$ のの1例, 差が0. $8 \mathrm{~dB}$ のもの1例である.

閶値上30dBでは差のないもの8例，差が0. $2 \mathrm{~dB} の も の$ 6例, 差が0. $4 \mathrm{~dB}$ のも 3 例, 差が0. $6 \mathrm{~dB}$ のも 3 例で ある。

閶值上40dBでは差のないもの7例，差が0.2dBのもの 11例, 差が0. $4 \mathrm{~dB}$ のもの 1 例, 差が0. $6 \mathrm{~dB} の も の 1$ 例で 苏る。

閔值上50dBでは差のないもの 8 例, 差が0.2dBのもの 11 例，差が0.8dBのもの1例である。

閔值上60dBでは差のないもの9 例, 差が0.2dBのもの 10例, 差が0.6dBのもの1例である.

$4 \mathrm{KC}$ において關值上10dBでは差のないもの8例, 差 が0.2dBのもの11例, 差が0. $4 \mathrm{~dB} の も の 1$ 例である.

闒值上20dBでは差のないもの9例, 差が0.2dBのもの 10例, 差が0. $4 \mathrm{~dB}$ のもの例である.

闒值上 $30 \mathrm{~dB}$ では差のないもの 7 例，差が0. $2 \mathrm{~dB}$ のも の10例，差が0. $4 \mathrm{~dB} の も の 3$ 例である.

閶值上40dBでは差のないもの13例, 差が0.2dBのもの .6例, 差が0. $4 \mathrm{~dB}$ のも 1 例である。

閔值上50dBで注差のないるの13例, 差が0.2dBのもの 7例である.

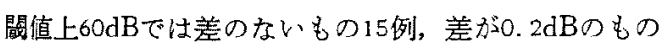
5 例である。

小括

以上の成績を小括すると， $1 \mathrm{KC}$ の閾値上 $20 \mathrm{~dB}$ と $30 \mathrm{~dB}$ 抄ける DL 值の最小值は夫々 $0.6 \mathrm{~dB}, 0.4 \mathrm{~dB}$, 最大值 は夫々 $2.0 \mathrm{~dB}, 1.6 \mathrm{~dB}$ である。 $4 \mathrm{KC}$ の䦭值上 $20 \mathrm{~dB}$ と 30 $\mathrm{dB}$ に抢ける $\mathrm{DL}$ 值の最小值は夫々 $0.6 \mathrm{~dB}, 0.4 \mathrm{~dB}$, 最大 值法々 $1.4 \mathrm{~dB}, 1.2 \mathrm{~dB}$ である

す柿わち，1KC，4KCで閔值上 $20 \mathrm{~dB}$ と $30 \mathrm{~dB}$ における DL值が夫々0.6dB，0. $4 \mathrm{~dB}$ 上り小のものはなく，又夫々 $2.0 \mathrm{~dB} ， 1.6 \mathrm{~dB}$ よ大きいものもない.

この結果加ら $1 \mathrm{KC}$ 又は $4 \mathrm{KC}$ 閶值上 $20 \mathrm{~dB}$ 乞 $30 \mathrm{~dB}$ 亿打 けるDL值が夫々0. $4 \mathrm{~dB}, 0.4 \mathrm{~dB}$ 以下のもの索小と主るこ
とが出来る。

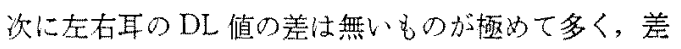
が0.2dBのものを含めると $1 \mathrm{KC}$ で注 $80 \%$ 以上を占め， $4 \mathrm{KC}$ で $95 \%$ \%占めている。

そして，各個人の左右耳の DL 值の相関をみると第 3

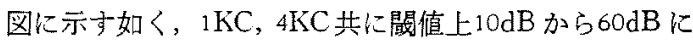
おいて耐耳の DL 值何机も正の相関を示している.

しかして各個人の左右耳の $\mathrm{DL}$ 值の差が゚. $4 \mathrm{~dB}$ 以上で あるのは，1KCでは120回中23回であり，4KCでも6回 に過ぎない，しかして1KCでかかる値を示したのは20例 中10例であるが，4KCでは 4 例に過ぎない．

第 2 節 伝音系難聴耳の成續

第 1 項 White noise による紌音闘值の変化

伝音系難聴耳として慢性中耳炎の20名21耳を対象に選 んだ.

これら21耳の成績は第 4 表（1～4）に示す如くであ る:

純音聴力の損失住 1 周波数に限らず，各周波数に及び 加えて各周波数の間に大差がない，それ故，闇值上昇が 高度な周波数として1，2の周波数だけ索対象とするこ とが出来ないので，純音闇值が最大純音閶值と $10 \mathrm{~dB}$ 以 内の範囲にある周波数を闘值上昇が高度な周波数として 記載した。

これらを noise audiogramによつて型に分けて記す 上次の如くである。

第1の型この闌值の変化は正常耳の多くに認めら礼 たもので, White noise を強くする每に純音閾値む上年 するものであつて，この群では全例がこの変化を示して いる.

第 2 の型 この型の閗値の変化は White noise 走強 くしても純音閵值は上昇しないものである。この群で

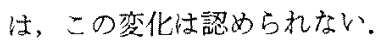

第 2 項 DL 值

この成績は第 4 表 $(1 \sim 4)$ に示す通りで, 關值上20 $\mathrm{dB}$ と30dBにおける $\mathrm{DL}$ 值は次の如くである.

1) $1 \mathrm{KC} \infty \mathrm{DL}$ 值

$0.8 \mathrm{~dB}$ と0.6dBのものは 1 耳で, 純音值間は $40 \mathrm{~dB}$ で ある。

$1.0 \mathrm{~dB}$ と0.8dBのものは 3 耳で, 純音閾值は $30 \mathrm{~dB} の$ もの1耳, $35 \mathrm{~dB} の も の 1 耳, 40 \mathrm{~dB}$ のも1耳でちる.

$1.2 \mathrm{~dB}$ と0.8dBのものは1耳で純音閵值は $45 \mathrm{~dB}$ であ

る.

1. $2 \mathrm{~dB}$ と $1.0 \mathrm{~dB}$ のもは8耳で，純音閂值仗 $35 \mathrm{~dB}$ の 
第 3 图 (1)

$1000 \mathrm{cps}$
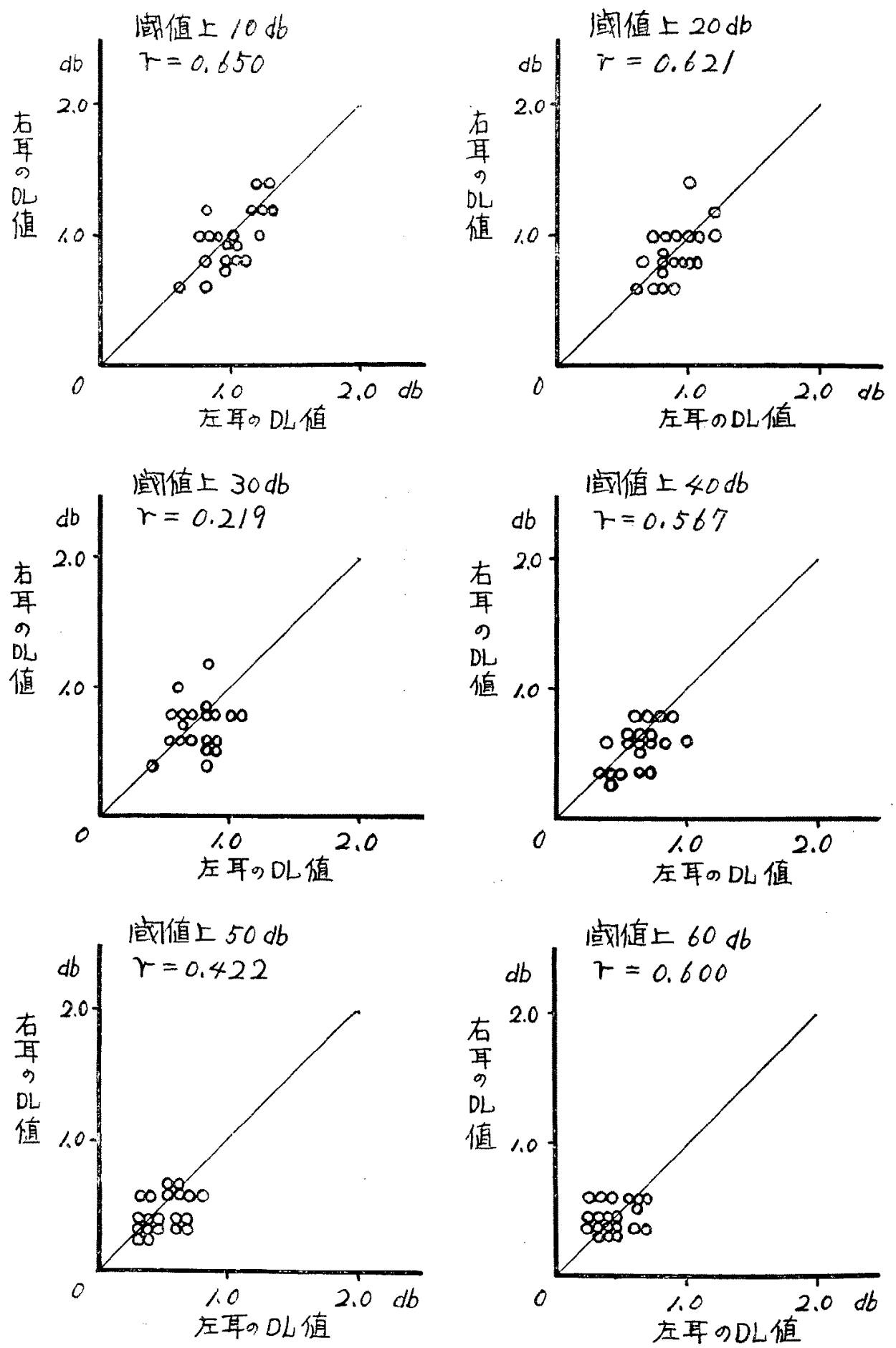

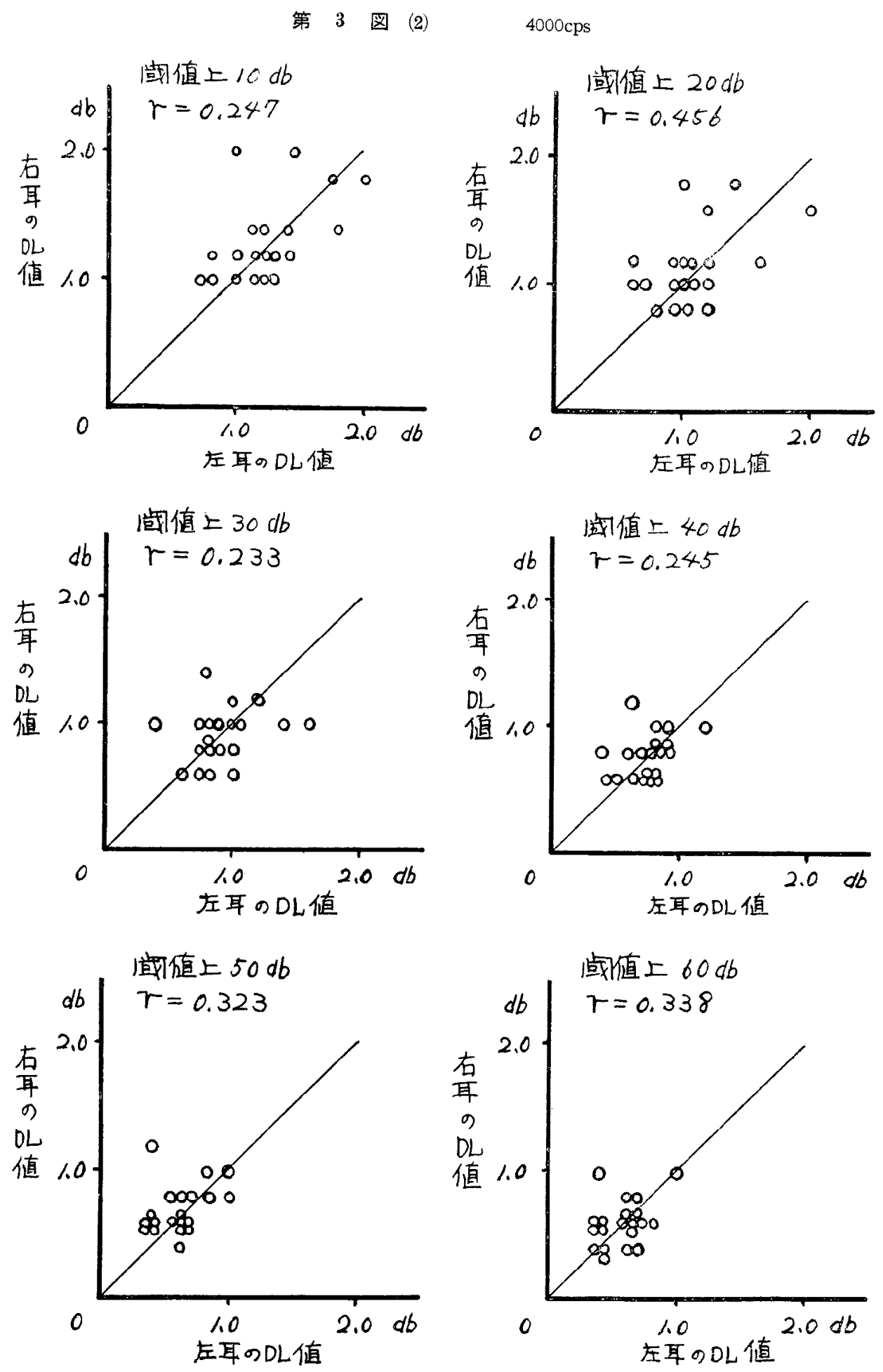
もの 3 耳, $40 \mathrm{~dB} の も の$ 耳, $45 \mathrm{~dB}$ のの1耳である.

1. $2 \mathrm{~dB}$ と1. $2 \mathrm{~dB}$ ものは 2 耳で, 純音闘值は 2 耳とも $45 \mathrm{~dB}$ である.

1. $4 \mathrm{~dB}$ と 1.2dBのものは 3 耳で, 純音闒值は35dBのも の 1 耳, $45 \mathrm{~dB}$ のの 2 耳である.

$1.6 \mathrm{~dB}$ と $1,4 \mathrm{~dB}$ ののは 3 耳で, 純音閶值は $40 \mathrm{~dB} の$

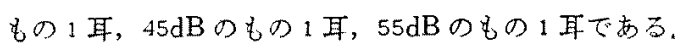

2) $4 \mathrm{KC} \sigma \mathrm{DL}$ 值

$0.8 \mathrm{~dB}$ と0.8dBのものは 2 耳で, 純音間值は $35 \mathrm{~dB} の$ もの 1 耳, $45 \mathrm{~dB} の も の$ 耳である。

$1.0 \mathrm{~dB}$ と $0.8 \mathrm{~dB}$ のものは 10 耳で，純音闒值は $35 \mathrm{~dB} の$ もの 3 耳, $40 \mathrm{~dB}$ のの 5 耳, $45 \mathrm{~dB}$ のも 2 耳である.

$1.0 \mathrm{~dB}$ と $1.0 \mathrm{~dB} の$ ものは 4 耳で, 純音閖は $35 \mathrm{~dB} の$

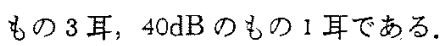

$1.2 \mathrm{~dB}$ と0.8dB のものは 1 耳で, 純音闒值は $45 \mathrm{~dB}$ で ある。

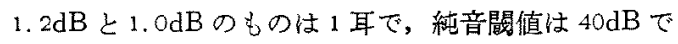
ある。

1. $2 \mathrm{~dB}$ と $1.2 \mathrm{~dB}$ のものは 1 耳で，純音關值は $40 \mathrm{~dB}$ で ある。

1. $4 \mathrm{~dB}$ と $1.4 \mathrm{~dB}$ のもの位 1 耳で, 純音闒值は $45 \mathrm{~dB}$ で ある。

$1.6 \mathrm{~dB}$ と $1.4 \mathrm{~dB}$ の の传 1 耳で, 純音闒值は $40 \mathrm{~dB}$ で ある。

小 括

伝音系難聴耳での White noise による閾値の変化は 次の如くである。

すなわち䦪值上昇の周波数に扔ける White noise に よる閔值の変化沈何れも White noise が強くなる毎に 閶值も上萛する第1の型の变化を示しており，White noise を強くしても閶值が上昇しない第 2 の型の変化を 示すものは認められない。

次にこの群の $1 \mathrm{KC} と 4 \mathrm{KC}$ 關值上 $20 \mathrm{~dB}$ と30dBにおけ るDL 值は次の如くである。

$1 \mathrm{KC}$ では閔值上 $20 \mathrm{~dB}$ と $30 \mathrm{~dB}$ における $\mathrm{DL}$ 值は夫々 $0.8 \mathrm{~dB} ， 0.6 \mathrm{~dB}$ から $1.6 \mathrm{~dB} ， 1.4 \mathrm{~dB}$ の閒にあり，正常者 に掞汀る DL 值と比較して中等値の範囲内にある.

$4 \mathrm{KC}$ では䦭值上 $20 \mathrm{~dB}$ 上 $30 \mathrm{~dB}$ における DL 值は夫々 $0.8 \mathrm{~dB} ， 0.8 \mathrm{~dB}$ から1.6dB，1.4dBの閒にあり，これを正 常者における DL 值上比較すると, 何れも中等值の範囲 内にある。

すなわち、この群の $1 \mathrm{KC} 上 4 \mathrm{KC} の$ 闒值上 $20 \mathrm{~dB} 々 30 \mathrm{~dB}$ に㧍ける DL 值は正常者と比較して何れも中等值の範囲
内にあるといえる。

第 3 節 騒音性難聴耳の成績

第 1 項 White noise に上る純音闇値の変化

名古屋市内某金属工場の従業員18名，32耳の成績は第 5 表 (1〜4) に示す如くである. 尚, この群において は最大間值注全例 $4 \mathrm{KC}$ に認められる dip 型である。

之を noise audiogram によつて $4 \mathrm{KC}$ を中心として型 に分けて示すと次の如くである。

第 1 の型 この型の間值の変化は正常耳の多くに認め られたもので, White noise を強くする毎に純音閔值も 上昇するものであるが，この群ではこの型の変化は認め られない。

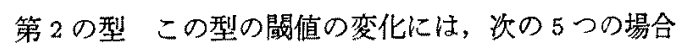
がある。

$\mathrm{A}$ ：第 4 図に示す如く，White noise $10 \mathrm{~dB}$ の時だけ閔 值が上昇せず White noise $20 \mathrm{~dB}$ 以上で閾值が上昇す るむの (2L. 3L. 9L. 10L, 16R)

$\mathrm{B}$ : 第 5 図に示方如く, White noise $10 \mathrm{~dB}, 20 \mathrm{~dB}$, の特 だけ閔值が変化せず, White noise $30 \mathrm{~dB}$ 以上で閔值 が上昇するもの（1L，2R，11R，12L，13R，15L，16L) $\mathrm{C}$ : 第6 図に示卞如 $<$, White noise $10 \mathrm{~dB}, 20 \mathrm{~dB}, 30 \mathrm{~dB}$ の時には闇值の変化がなく, White noise $40 \mathrm{~dB}$ で闒 值の変化がある の $(1 \mathrm{R}, 4 \mathrm{R}, 4 \mathrm{~L}, 5 \mathrm{R}, 5 \mathrm{~L}, 6 \mathrm{R}, 7 \mathrm{R}$, $7 \mathrm{~L}, 9 \mathrm{R}, 10 \mathrm{R}, 11 \mathrm{~L}, 14 \mathrm{R}, 17 \mathrm{~L}, 18 \mathrm{~L})$

$\mathrm{D}$ : 第 7 図に示寸如く White noise $10 \mathrm{~dB}, 20 \mathrm{~dB}, 30 \mathrm{~dB}$, 40dBで閾值が変化しないもの (17R, 18R)

$\mathrm{E}$ : 第 8, 9 図に示す如く, White noise $10 \mathrm{~dB}$ で閶值 が僅かに変化するが, White noise $10 \mathrm{~dB}$ と20dB, 時 には $30 \mathrm{~dB}$ でも閾值の変化が同じもの $(3 \mathrm{R}, 6 \mathrm{~L}, 8 \mathrm{R}$, 8L)となる.

第 2 項 最大間値周波数 $(4 \mathrm{KC})$ 附近の周波数に扝 ける White noise による閵值の変化

最大閶值周波数の附近の周波数の閾值が White noise によってどのように変化しているかを第1 項で記載した 種々の閶値の変化の型で記すと次の如くである.

第1の型のもの，すなわち $4 \mathrm{KC}$ 以外で White noise を強くするに従い純音間值の上昇するものは，2L，3L, $4 \mathrm{~L}, 5 \mathrm{~L}, 6 \mathrm{R}, 7 \mathrm{R}, 7 \mathrm{~L}, 8 \mathrm{R}, 8 \mathrm{~L}, 9 \mathrm{~L}, 10 \mathrm{R}, 10 \mathrm{~L}$ 12耳であ 3.

第 2 の型のAのむの,すなわち $4 \mathrm{KC}$ 以外で White noise $10 \mathrm{~dB}$ 時は純音閶値の変化なく, White noise $20 \mathrm{~dB}$ 以 上では純音閾値は次第に上昇するものは $1 \mathrm{R} の 0.5 \mathrm{KC}, 1 \mathrm{~L}$ の. 5KC, 2Rの0,5KC, 6KC, 3Rの6KC, 4Rの8KC, 6L 
第 4 图症洌潘步 $2 \mathrm{~L}$

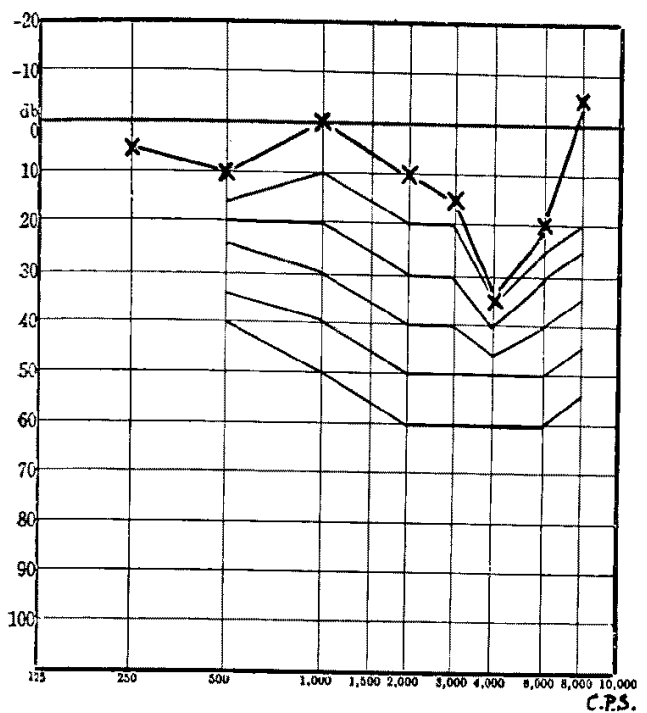

墱 5 図症例番号 1 L

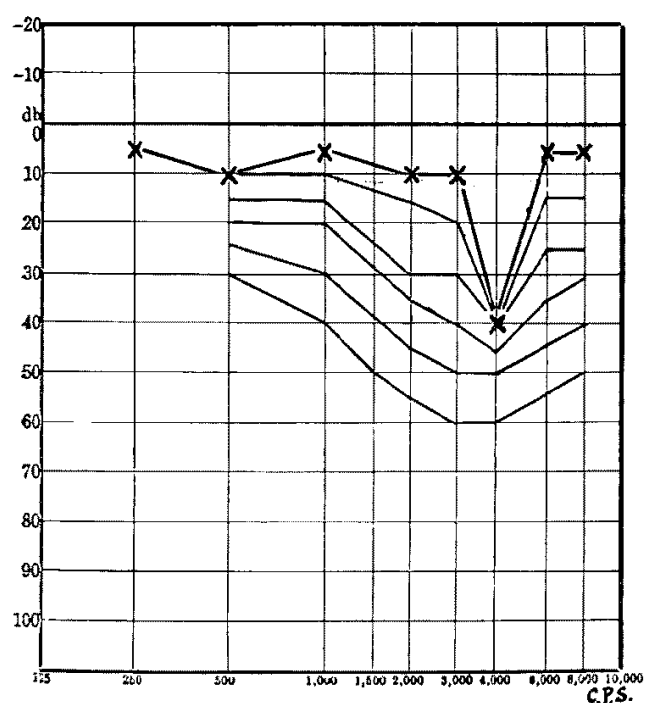

の8KC, 9Rの8KC, $11 \mathrm{~L} の 0.5 \mathrm{KC}, 12 \mathrm{~L} の 2 \mathrm{KC}, 3 \mathrm{KC}, 13 \mathrm{R}$ の $\mathrm{KC}, 3 \mathrm{KC}, 15 \mathrm{~L} の 2 \mathrm{KC}, 3 \mathrm{KC}, 16 \mathrm{~L} の 3 \mathrm{KC}, 12 \mathrm{~L} 02 \mathrm{KC}$, 3KCの12耳である。

しかして1Rの0.5KCの純音䦪值は $5 \mathrm{~dB}$ であり，1Lの $0.5 \mathrm{KC} 10 \mathrm{~dB}, 2 \mathrm{R} の 0.5 \mathrm{KC}$ 沬10dB，6KCは15dB，3Rの $6 \mathrm{KC}$ は10dB，4Rの8KCは15dB，6Lの8KCは15dB，9Rの $8 \mathrm{KC}$ は $10 \mathrm{~dB}, 11 \mathrm{~L} 00.5 \mathrm{KC}$ は10dB, $12 \mathrm{~L}$ の2 KC, 3KC は 夫ヶ $5 \mathrm{~dB}, 13 \mathrm{R} の 2 \mathrm{KC}, 3 \mathrm{KC} 夫 \nLeftarrow 0 \mathrm{~dB}, 5 \mathrm{~dB}$
第 6 图症例舀㗉 1 R

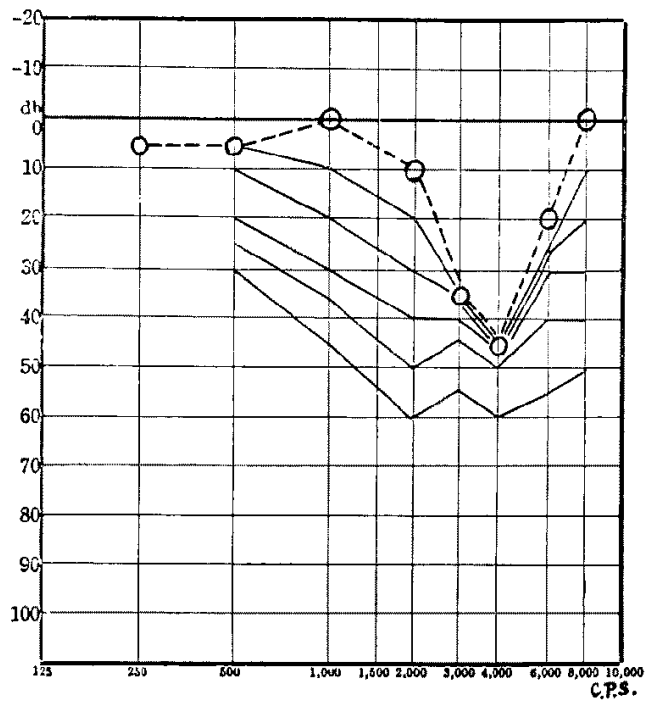

第 7 图䇥洌萿号 $17 \mathrm{R}$

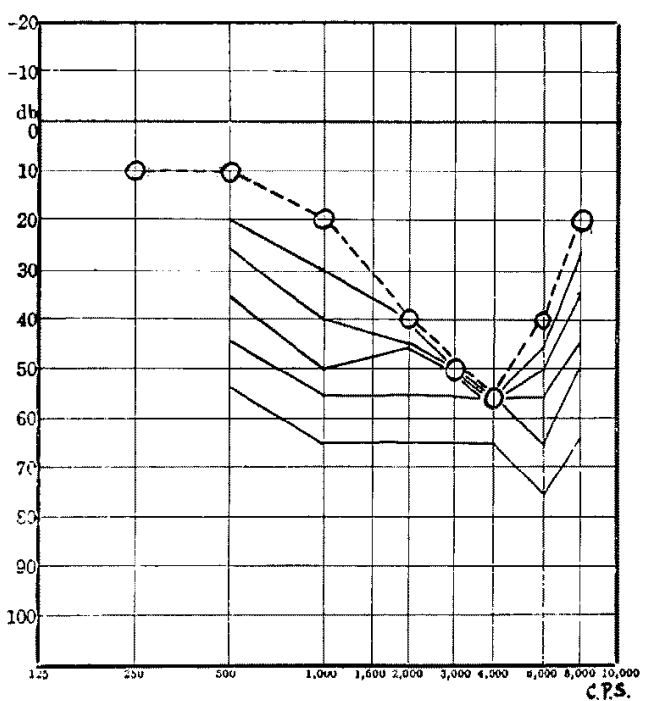

の2KC, 3KC は夫々 $5 \mathrm{~dB}, 15 \mathrm{~dB}, 16 \mathrm{~L} の 3 \mathrm{KC}$ は20dB, 17 LO2KC, 3KCは夫々 $20 \mathrm{~dB}$ である。

第 2 型のAとBの合併したもの，すなわち $4 \mathrm{KC}$ 以外 で White noise 10dBの時は純音閝值は変化しないが, White noise $20 \mathrm{~dB}$ 以上では順次増大する周波数々， White noise $10 \mathrm{~dB}$ と20dBでは純音䦪值の変化はないが, White noise $30 \mathrm{~dB}$ 以上では順次増大する周波数のある ものは11Rの3KC巳6KC, 14Rの2KCと3KC, 16Rの2KC, 
第 8 图症例番号 $8 \mathrm{R}$

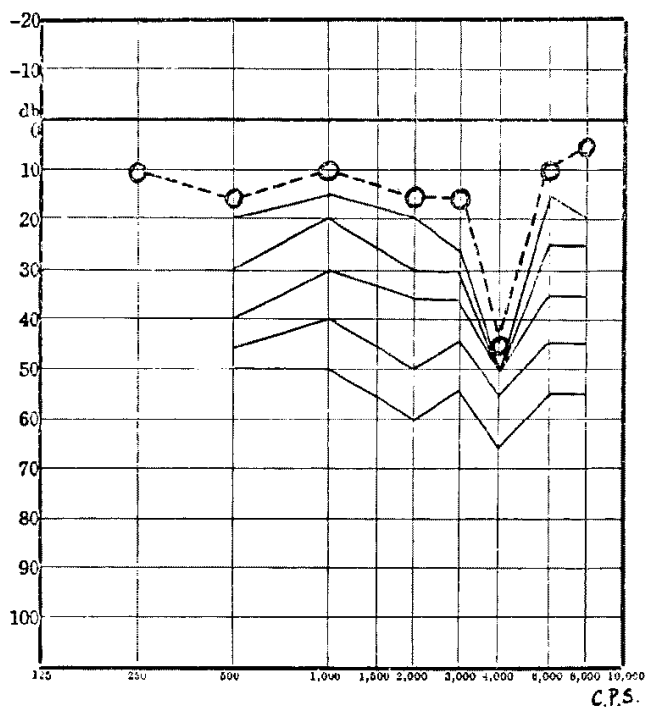

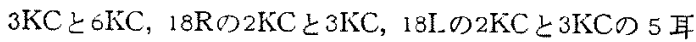
である。

しかして，11Rの $3 \mathrm{KC} ， 6 \mathrm{KC}$ の純音閔值は夫々 $30 \mathrm{~dB}$, $15 \mathrm{~dB}, 14 \mathrm{R} の 2 \mathrm{KC}, 3 \mathrm{KC}$ は夫 $10 \mathrm{~dB}, 25 \mathrm{~dB}$ であり，16R の $2 \mathrm{KC}, 3 \mathrm{KC}, 6 \mathrm{KC}$ はネ $20 \mathrm{~dB}, 25 \mathrm{~dB}, 25 \mathrm{~dB}$ であり，18 $\mathrm{R}$ の $2 \mathrm{KC}, 3 \mathrm{KC}$ は夫々 $30 \mathrm{~dB}, 4 \mathrm{OdB}$ であり, $18 \mathrm{~L}$ の $2 \mathrm{KC}$, $3 \mathrm{KC}$ は夫々 $15 \mathrm{~dB}, 25 \mathrm{~dB}$ である。

第 2 の型のAとCの合併したもの，寸なわち4KC以外 で White noise $10 \mathrm{~dB} の$ 時は純音闇值の変化はないが, White noise $20 \mathrm{~dB}$ 以上では順次增大寸る周波数とWhite noise $10 \mathrm{~dB}, 20 \mathrm{~dB}, 30 \mathrm{~dB}$ では純音䦏值の変化はないが, White noise $40 \mathrm{~dB}$ 以上では順次增大する周波数のある むのは17R の2KCと3KCである。

しかして17R の2 KC，3KCの純音間值は夫々 $40 \mathrm{~dB}, 50$ dBである。

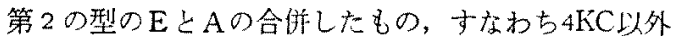
で White noise $10 \mathrm{~dB}$ の時には純音闘值が変化するが， White noise $10 \mathrm{~dB}$ と $20 \mathrm{~dB} の$ 時の純音閏值の変化吕等し く, White noise $30 \mathrm{~dB}$ 以上では順次增大する周波数と， White noise $10 \mathrm{~dB}$ の時に法絈音間值は変化しないが, White noise $20 \mathrm{~dB}$ 以上では順次增大する周波数のある むのは5R の6KCと8KCである。

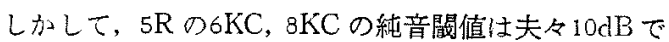
ある。

第 2 の型の $\mathrm{E}$ と $\mathrm{B}$ 合併したもの，すなわら $4 \mathrm{KC}$ 外
第 9 图症例霜号 $3 \mathrm{R}$

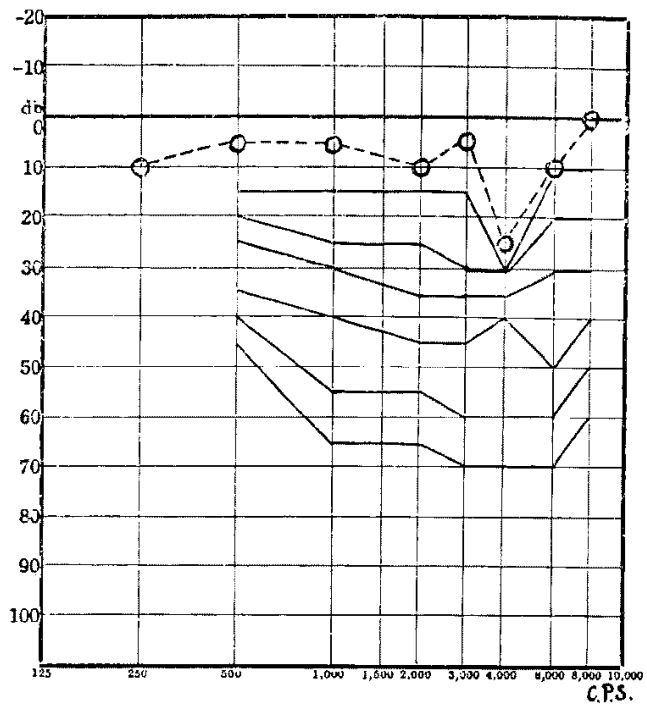

て White noise $\operatorname{lodB}$ の時には純音简值が変化するが, White noise $10 \mathrm{~dB}$ と20dBの時の絈音閾值の変化は等し いが, White noise $30 \mathrm{~dB}$ 以上では順次堌大する周波数 と. White noise $10 \mathrm{~dB}$ と20dB の時に注純音閶值は変化 しないが，White noise 30dB 以上では順次増大する周 波数があるものは1Rの3KC と6KCである。

しかして $1 \mathrm{R} の 3 \mathrm{KC} と 6 \mathrm{KC}$ の純音閦値は夫ヶ $35 \mathrm{~dB}$ 上 20 dBである。

以上からして，第 2 の型を示すものは純音閔值が上昇 しているのであるが, $12 \mathrm{~L} の 2 \mathrm{KC}$ と $3 \mathrm{KC}, 13 \mathrm{R}$ の2KC と $3 \mathrm{KC}, 15 \mathrm{~L}$ 2 $\mathrm{KC}$ では純音閾值は正常值範囲内にあるが， 第 2 の型を示している。

一方純音間值の上昇が明らかであつてを第 2 の型を示 さないるのがある。

すなわち $2 \mathrm{~L}$ の $3 \mathrm{KC}$ と $6 \mathrm{KC}, 4 \mathrm{R} の 2 \mathrm{KC}$ と $3 \mathrm{KC}, 4 \mathrm{~L} の 2$ $\mathrm{KC}, 3 \mathrm{KC}\llcorner 6 \mathrm{KC}, 5 \mathrm{~L}$ $03 \mathrm{KC}, 6 \mathrm{R} 06 \mathrm{KC}, 6 \mathrm{~L} \oplus 6 \mathrm{KC}$ <8 $\mathrm{KC}, 7 \mathrm{R} 06 \mathrm{KC}, 7 \mathrm{~L} 06 \mathrm{KC}, 8 \mathrm{R} 03 \mathrm{KC}, 9 \mathrm{R}$ $03 \mathrm{KC}, 9 \mathrm{~L}$ の $3 \mathrm{KC} \succeq 6 \mathrm{KC}, 10 \mathrm{R} 02 \mathrm{KC}, 3 \mathrm{KC}, 6 \mathrm{KC} \_8 \mathrm{KC}, 12 \mathrm{~L} 06 \mathrm{KC}$, $14 \mathrm{R} \sigma 6 \mathrm{KC}, 17 \mathrm{R} \sigma 1 \mathrm{KC}, 6 \mathrm{KC} \_8 \mathrm{KC}, 17 \mathrm{~L} 06 \mathrm{KC}\llcorner 8 \mathrm{KC}$, $18 \mathrm{R} \sigma 6 \mathrm{KC}$ と $8 \mathrm{KC}, 18 \mathrm{~L} の 6 \mathrm{KC}$ と $8 \mathrm{KC}$ である.

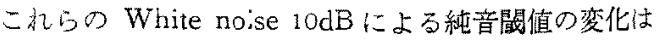
$5 \mathrm{~dB}$ もの19, $10 \mathrm{~dB} の も 1,15 \mathrm{~dB}$ もの1である.

第 3 項 DL 值

この成績第 5 表 $(1 \sim 4)$ に示す通りで, 閔值上20 $\mathrm{dB}$ と3OdBにおける DL 值は次の如くである。 


\section{1) $1 \mathrm{KC} の \mathrm{DL}$ 值}

$0.6 \mathrm{~dB}$ と0.6dBのbのは 1 耳で純音闒值は0dBである. $0.8 \mathrm{~dB}$ と0. $6 \mathrm{~dB}$ のもは 4 耳で純音閾值は一 $5 \mathrm{~dB} の も$ の 1 耳, $5 \mathrm{~dB} の も 2 耳, 20 \mathrm{~dB}$ あの 1 耳である.

$0.8 \mathrm{~dB}$ と0. $8 \mathrm{~dB}$ ののは 21 耳で, 純音閶値は一 $5 \mathrm{~dB} の$ もの 2 耳, $0 \mathrm{~dB} の も の 耳, 5 \mathrm{~dB}$ の の5耳, $10 \mathrm{~dB} の も$ の6耳である。

$1.0 \mathrm{~dB}$ と0. $8 \mathrm{~dB} の も の は 5$ 耳で，純音閧值は0dBのも の3耳, $5 \mathrm{~dB} の も の 耳, 10 \mathrm{~dB} の$ 母の 1 耳である.

$0.8 \mathrm{~dB}$ と1. $0 \mathrm{~dB} の$ ものは 1 耳で, 純音閶值は $0 \mathrm{~dB}$ であ 万.

\section{2) $4 \mathrm{KC} の \mathrm{DL}$ 值}

$0.4 \mathrm{~dB}$ と0.2dBのものは 1 耳で, 純音闒值は $45 \mathrm{~dB}$ であ Ђ.

$0.4 \mathrm{~dB}$ と0. $4 \mathrm{~dB}$ ものは24耳で, 純音䦪值は25dBのも の 3耳, $30 \mathrm{~dB} の も の$ 耳, $35 \mathrm{~dB}$ のの 4 耳, $40 \mathrm{~dB} の$ も の9耳, $45 \mathrm{~dB} の も の 4$ 耳, $50 \mathrm{~dB} の も の 1$ 耳である、

$0.6 \mathrm{~dB} と 0.4 \mathrm{~dB}$ ののは 2 耳で, 純音䦪值は $35 \mathrm{~dB}$ と 50 $\mathrm{dB}$ である。

$0.6 \mathrm{~dB}$ と0. $6 \mathrm{~dB}$ ののは 3 耳で，純音閵值は $25 \mathrm{~dB}, 40$ $\mathrm{dB}$ 及び45dBである。

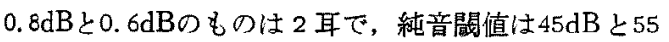
$\mathrm{dB}$ である。

以上からして $1 \mathrm{KC}$ の閶值上 $20 \mathrm{~dB}$ と $30 \mathrm{~dB}$ における $\mathrm{DL}$ 值は寸心゙て0.6dBと0. $4 \mathrm{~dB}$ 以上, $2.0 \mathrm{~dB} と 1.6 \mathrm{~dB}$ 以下で あり, 純音闃值は20dBである17R以外はすべてー $5 \mathrm{~dB}$ ら10dBの間にある。

4KCでは純音間值はすべて上昇しているが，䦪值上 $20 \mathrm{~dB}$ と $30 \mathrm{~dB}$ におりるDL值は0. $4 \mathrm{~dB}$ と0. $4 \mathrm{~dB}$ 以下のもの 25 耳, 0.6dBと0. 4dB以上のものが15L, 16R, 16L, 17R, 17L, 18R, 18Lの7耳る.

小括

騒音性難聴耳の闒值上昇が高度の周波数に掠いては

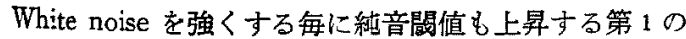
型の変化を示すものはなく, White noise の強さを增し ても純音閖值の変化しないものが多い，

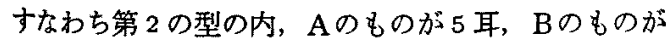

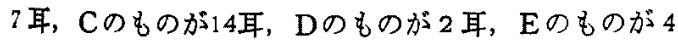
耳である。

このように純音闇值が変化しないものは White noise $10 \mathrm{~dB}$ では1〜3周波数にみられるが, White noise が $20 \mathrm{~dB}, 30 \mathrm{~dB}$ となると純音閵值の変化しない周波数は限 定され，純音閣値が最も変化し難いのは關值上昇が高度
な周波数，すなわら $4 \mathrm{KCKおいてである。}$

しかして䦪值上昇が高度な周波数の純音闎值とWhite noise による閔值の変化の型を螕めると次の如くである. すなわら White noise $10 \mathrm{~dB}$ の時だけ闒值が変化しな 、第 2 の型のA を示す症例の純音䦪值は $25 \mathrm{~dB}, 30 \mathrm{~dB}, 35$ $\mathrm{dB}, 40 \mathrm{~dB}$ である. White noise $10 \mathrm{~dB}, 20 \mathrm{~dB}$ で間值が 変化しない第 2 の型のB示症例では25dB, $30 \mathrm{~dB}, 35$ $\mathrm{dB}, 40 \mathrm{~dB}$ である. White noise $10 \mathrm{~dB}, 20 \mathrm{~dB}$ 及び30dBで 閖值が変化しない第 2 の型の Cを示症例では $35 \mathrm{~dB}, 40$ $\mathrm{dB}, 45 \mathrm{~dB}, 50 \mathrm{~dB}$ である. White noise $10 \mathrm{~dB}, 20 \mathrm{~dB}, 30$ $\mathrm{dB}$ 及び $40 \mathrm{~dB}$ で間值が変化しない第 2 の型のDを示す症 例では50dB，55dBである。

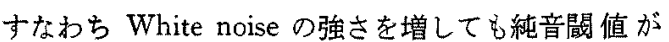
変化しない症例ではその周波数 $(4 \mathrm{KC})$ の純音閾值の上 昇が高度なるのがやや多い。

次に䦪值上昇が高度な周波数附近の周波数における White noise による闒值の変化は第 1 の型を示すものと 第 2 の型を示すものがある。

第 1 の型を示すものの純音闒值は $5 \mathrm{~dB}$ から $25 \mathrm{~dB}$ の閒 にある、

第2の型を示すものの純音闒值は OdB から50dBの間 にある、しかして純音閶值が0dBから10dBの正常範囲内 にあつて第 2 の型のA変化をするのは3R の6KC, 5Rの8 $\mathrm{KC}, 9 \mathrm{R}$ の $\mathrm{KC}, 12 \mathrm{~L}$ の $2 \mathrm{KC} と 3 \mathrm{KC}, 13 \mathrm{R}$ の $2 \mathrm{KC}$ と $3 \mathrm{KC}$, $14 \mathrm{R}$ 2 $2 \mathrm{KC}, 15 \mathrm{~L}$ 2KC であり， Eの変化をするのは 5R の6KCであつて少ない.

次に騒音性難聴耳の $1 \mathrm{KC}$ と $4 \mathrm{KC}$ の誾值上 $20 \mathrm{~dB} と 30 \mathrm{~dB}$ における DL 值は次の如くである.

$1 \mathrm{KC}$ では闘值上 $20 \mathrm{~dB}$ と $30 \mathrm{~dB}$ の DL 值は夫々0. $8 \mathrm{~dB}$ と $0.6 \mathrm{~dB}$ から1.0dB と0.8dBの間にあり，正常者における DL 值からみて中等值の範囲内に入つている。

$4 \mathrm{KC}$ では閶值上 $20 \mathrm{~dB}$ と $30 \mathrm{~dB}$ の DL 值は夫々0. $4 \mathrm{~dB}$ と $0.2 \mathrm{~dB}$ から0.8dB と0. $6 \mathrm{~dB}$ の閒にある。これを正常者に おける DL 值と比較すると0. $4 \mathrm{~dB}$ と0. $4 \mathrm{~dB}$ 以下の異常に 小さい值のものが25耳で, $0.6 \mathrm{~dB}$ と0. $4 \mathrm{~dB}$ 以上で中等值 の範囲内のむのが 7 耳ある。

しかして閶值上昇が高度な周波数（この群では $4 \mathrm{KC}$ )

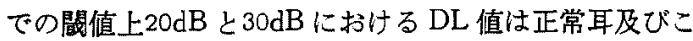
の群の1KCにおける值より明らかに小いものが多い，

第 4 節 老人性難聴耳成績

第 1 項 White noise による純音䦥值の変化

名古屋市内某老人ホームの老人 14 名 28 耳の成績は第 6 表 (1〜3) に示す如くである. 
第 10 図症例番号 $30 \mathrm{~L}$

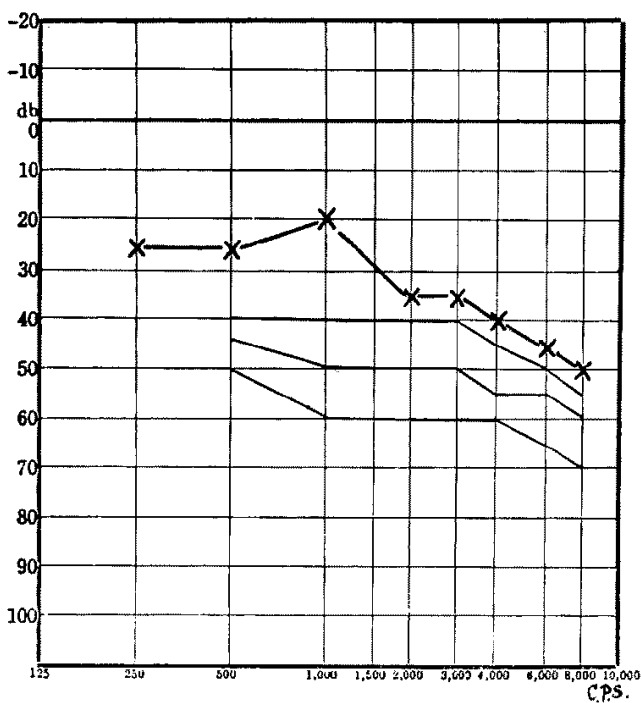

第 11 図症例番号 $30 \mathrm{R}$

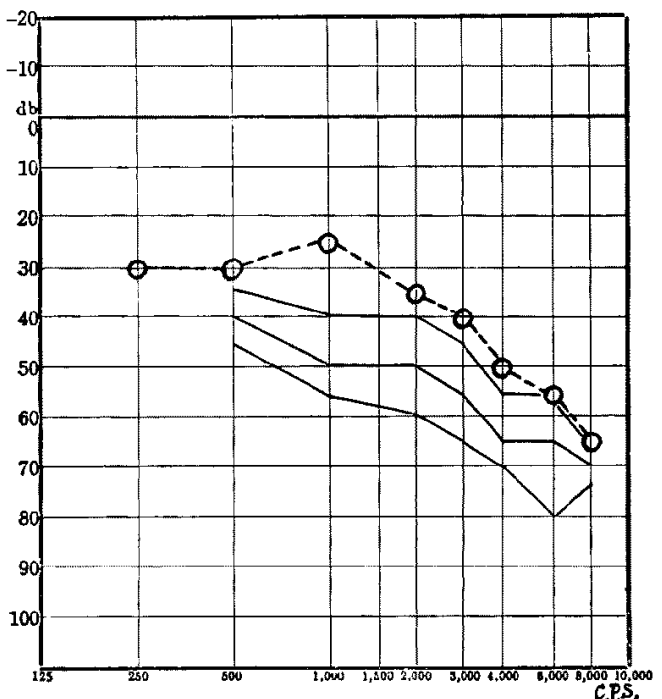

この群においては閶值上昇が高度な周波数が に限られる場合はむしろ少ない，乙れ故閶值上昇が高度 な周波教としては最大閶值を示す周波数と最大闒值と $10 \mathrm{~dB}$ 以内の閾値にある周波数を対象とした.

これらを noise audiogramによつで型に分けて記す と次の如くである。

第1の型 第10図に示す如くWhite noise 強くす る毎に純音閶值も上昇するもの（19Rの $1 \mathrm{KC}, 2 \mathrm{KC}, 3$
第 12 图㱏例番号 $26 \mathrm{~L}$

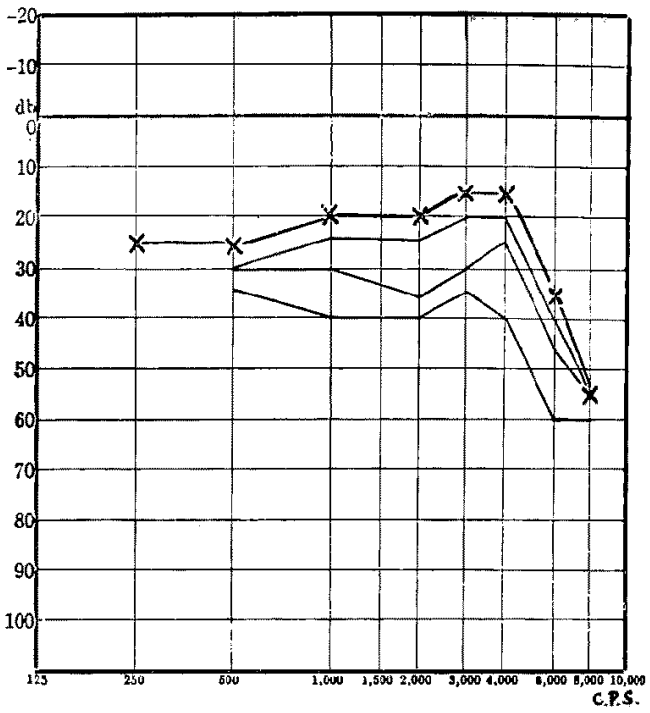

第 13 図症例番号 $24 \mathrm{R}$

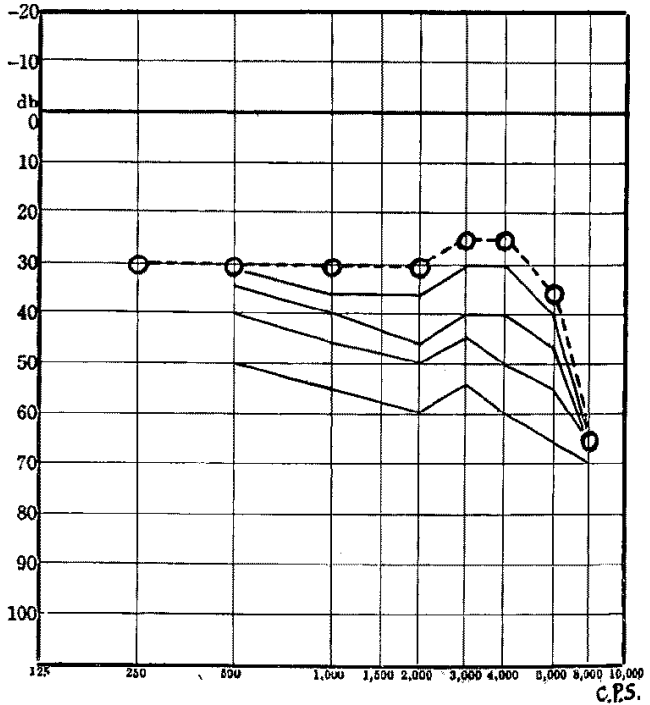

$\mathrm{KC}, 4 \mathrm{KC}, 6 \mathrm{KC}, 22 \mathrm{~L}$ $6 \mathrm{KC}$ と $8 \mathrm{KC}, 26 \mathrm{R}$ $08 \mathrm{KC}, 30 \mathrm{~L} の$ $4 \mathrm{KC}, 6 \mathrm{KC} と 8 \mathrm{KC}, 32 \mathrm{R} の 6 \mathrm{KC}$ と $8 \mathrm{KC}, 32 \mathrm{~L} の 6 \mathrm{KC}$ と $8 \mathrm{KC})$ 第 2 の型この闒值の変化には第 2 節第 1 項に記した 如く，次の 5 つの場合がある.

A : 第11図に示す如くWhite noise 10dBの時だけ閖值 が変化せず, White noise $20 \mathrm{~dB}$ 以上で間值が上昇す るむの (30R の6KC と $8 \mathrm{KC}, 31 \mathrm{R} の 8 \mathrm{KC})$

B：第12図に示守如く White noise $10 \mathrm{~dB}, 20 \mathrm{~dB} の$ 時だ 
第 14 图症例番号 $22 \mathrm{R}$

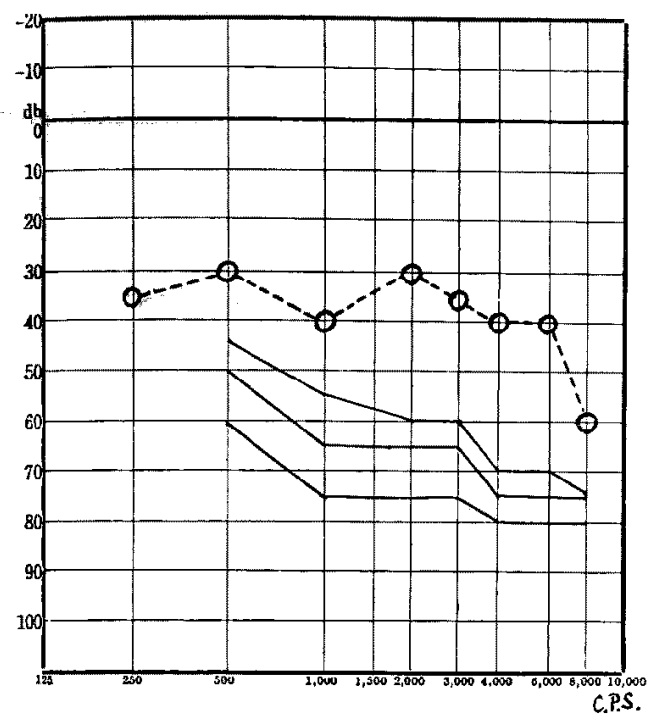

け闌值が変化せず，White noise 3odB 以上で間值が 上昇するもの $(26 \mathrm{~L} の 8 \mathrm{KC})$

C: 第13図に示寸如く White noise $10 \mathrm{~dB}, 20 \mathrm{~dB}, 30 \mathrm{~dB}$ の時には䦪值の変化がなく, White noise $40 \mathrm{~dB}$ で閔 值の変化があるもの $(24 \mathrm{R} の 8 \mathrm{KC})$

D：第 7 図に示す如 $<$ White noise $10 \mathrm{~dB}, 20 \mathrm{~dB}, 30 \mathrm{~dB}$, 40dB で闒值が変化しないものであるが，この群には ない。

E：第14図に示す如くWhite noise $10 \mathrm{~dB}$ の時には純音 䦪值が変化するが，White noise $20 \mathrm{~dB}$ の時又は $30 \mathrm{~dB}$ の時も閔值の変化が White noise $10 \mathrm{~dB}$ の時と同じで White noise 30dB又は40bB 以上では順次増大寸るも の (22Rの8KC, 25Rの8KC, 27Rの $4 \mathrm{KC}, 6 \mathrm{KC} と 8 \mathrm{KC}$, $29 \mathrm{R} の 8 \mathrm{KC})$ となる.

以上の 5 つの型の他に 2 つの型が合併しているものが ある。

AとEの合併したもの，すなわち White noise $10 \mathrm{~dB}$ の時汇注閶值の変化がなく, White noise $20 \mathrm{~dB}$ と $30 \mathrm{~dB}$

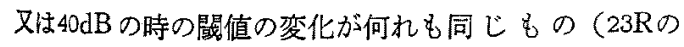
$4 \mathrm{KC}, 6 \mathrm{KC}$ と $8 \mathrm{KC}, 24 \mathrm{~L}$ のKC, $27 \mathrm{~L}$ の $8 \mathrm{KC}, 28 \mathrm{R} の 4 \mathrm{KC}$, $6 \mathrm{KC}$ と $8 \mathrm{KC})$

$\mathrm{B} と \mathrm{E}$ の合併したもの，すなわち White noise $10 \mathrm{~dB}$ と20dBの時には闒値は変化しないが，White noise 30 $\mathrm{dB}$ 以上で注順次增大寸る周波数と，White noise $10 \mathrm{~dB}$ と20dBの時の閔値の変化汢等しく, White noise $30 \mathrm{~dB}$
以上では順次增大するもの（21Lの $2 \mathrm{KC}, 3 \mathrm{KC}, 4 \mathrm{KC}, 6$ $\mathrm{KC}, \mathrm{BKC})$

以上の他に閔值上㫒が高度な周波教において，第 10 型々第 2 の型が合併している場合がある。

すかわち第 1 の型と第 2 の型のAとが合併しているも の $(20 \mathrm{~L}$ の $6 \mathrm{KC}, 8 \mathrm{KC}, 21 \mathrm{R}$ の $1 \mathrm{KC}, 2 \mathrm{KC}, 3 \mathrm{KC}, 4 \mathrm{KC}, 6$ $\mathrm{KC}, 8 \mathrm{KC}, 29 \mathrm{~L} の 1 \mathrm{KC}, 2 \mathrm{KC}, 3 \mathrm{KC}, 4 \mathrm{KC}, 6 \mathrm{KC}, 8 \mathrm{KC}$ )

第 1 の型と第 2 の型の $\mathrm{E}$ とが合併しているもの（19L の $\mathrm{KC}, 2 \mathrm{KC}, 3 \mathrm{KC}, 4 \mathrm{KC}, 20 \mathrm{~L} の 4 \mathrm{KC}, 6 \mathrm{KC}, 8 \mathrm{KC}, 25 \mathrm{~L}$ の $6 \mathrm{KC}, 8 \mathrm{KC}, 31 \mathrm{~L} \omega 6 \mathrm{KC}, 8 \mathrm{KC})$

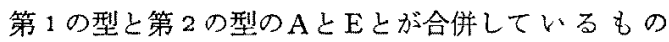
(28L $4 \mathrm{KC}, 6 \mathrm{KC}, 8 \mathrm{KC})$

第 1 の型上第 2 の型の B と C とが合併しているもの $(23 \mathrm{~L}$ $4 \mathrm{KC}, 6 \mathrm{KC}, 8 \mathrm{KC})$ となる.

第 2 項 闒值上昇が高度の周波数附近の周波数にお ける White noise による閏值の変化

閔值上昇が高度な周波教では White noise によつて, どのように閔值変化しているかを第1項で記載した種々 の䦪值の変化の型で記すと次の如くである.

第 1 の型, すなわち閵値上昇が高度の周波数附近で White noise を強くするに従い純音閾値の上界するもの は19Rの8KC, $19 \mathrm{~L} の 6 \mathrm{KC}$ と $8 \mathrm{KC}, 20 \mathrm{R} の 3 \mathrm{KC}$ と $4 \mathrm{KC}, 22 \mathrm{R}$ の $4 \mathrm{KC}$ と $6 \mathrm{KC}, 22 \mathrm{~L} の 3 \mathrm{KC} と 4 \mathrm{KC}, 23 \mathrm{~L}$ の $2 \mathrm{KC}$ と $3 \mathrm{KC}, 24$ $\mathrm{R}$ $4 \mathrm{KC}$ と $6 \mathrm{KC}, 25 \mathrm{~L}$ の $3 \mathrm{KC} と 4 \mathrm{KC}, 26 \mathrm{R}$ の $4 \mathrm{KC}$ と $6 \mathrm{KC}$, $26 \mathrm{~L} の 4 \mathrm{KC} と 6 \mathrm{KC}, 27 \mathrm{R}$ 2 $\mathrm{KC}$ と $3 \mathrm{KC}, 28 \mathrm{R}$ 2 $\mathrm{KC}$ と $3 \mathrm{KC}$, $29 \mathrm{R} の 4 \mathrm{KC} と 6 \mathrm{KC}, 30 \mathrm{R}$ 3 $\mathrm{KC} と 4 \mathrm{KC}, 30 \mathrm{~L}$ $2 \mathrm{KC} と 3 \mathrm{KC}$, $31 \mathrm{~L}$ の $3 \mathrm{KC}$ と $4 \mathrm{KC}, 32 \mathrm{R}$ の $3 \mathrm{KC}$ と $4 \mathrm{KC}, 32 \mathrm{~L}$ の $3 \mathrm{KC}$ と $4 \mathrm{KC}$ の18耳である。

第 2 の型のAのもの，すなわち闖值上昇が高度の周波 数附近の周波数で, White noise $\operatorname{10dB}$ の時は純音闒值 の変化なく, White noise $20 \mathrm{~dB}$ 以上で純音闒值は次 第に上昇するもの汒 $23 \mathrm{R} の 2 \mathrm{KC}$ と $3 \mathrm{KC}, 25 \mathrm{R}$ の $4 \mathrm{KC}$ と6 $\mathrm{KC}, 28 \mathrm{~L} の 2 \mathrm{KC}, 31 \mathrm{R} の 4 \mathrm{KC}$ 飞 $6 \mathrm{KC} 4$ 耳である.

第 2 の型のBのもの，Cのもの，Dのものはない．

第 2 の型の $\mathrm{E} の も の は 20 \mathrm{~L} の 2 \mathrm{KC}$ と $3 \mathrm{KC}, 24 \mathrm{~L}$ の $6 \mathrm{KC}$, 27Lの6KCの 3 耳である。

第 3 項 DL 值

この成績法第6表 $(1 \sim 3)$ に示寸通りで, 闒値上 20 $\mathrm{dB} と 30 \mathrm{~dB}$ におけるDL值は次の如くである.

1) $1 \mathrm{KC} の \mathrm{DL}$ 值

$0.8 \mathrm{~dB}$ と0. $6 \mathrm{~dB}$ のものは 1 耳で純音閶值は $30 \mathrm{~dB}$ であ る.

$0.8 \mathrm{~dB}$ と0.8dBのものは 3 耳で純音闘値は $25 \mathrm{~dB}$ のも 
の1耳, 30dBのもの2耳である。

$0.6 \mathrm{~dB}$ と0.8dBのものは 2 耳で純音閵值は $20 \mathrm{~dB}$ と 30 dBである.

$1.0 \mathrm{~dB}$ と $0.6 \mathrm{~dB}$ ののは 2 耳で，純音閾值は夫々 30 $\mathrm{dB}$ である.

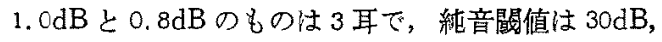
$35 \mathrm{~dB}, 55 \mathrm{~dB}$ である。

$1.0 \mathrm{~dB}$ と $1.0 \mathrm{~dB}$ ののは 3 耳で, 純音䦪值は $25 \mathrm{~dB}$ の

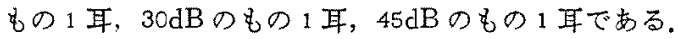

1. $2 \mathrm{~dB}$ と $1.0 \mathrm{~dB}$ のものは 2 耳で，純音閶值は $30 \mathrm{~dB}$ と $40 \mathrm{~dB}$ である.

$1.4 \mathrm{~dB}$ と0. $8 \mathrm{~dB}$ のものは 1 耳で, 純音䦪值は $20 \mathrm{~dB}$ ある。

$1.4 \mathrm{~dB}$ と $1.2 \mathrm{~dB}$ のものは 5 耳で，䊼音閶値は $30 \mathrm{~dB} の$ もの 2 耳, $35 \mathrm{~dB}, 40 \mathrm{~dB}, 50 \mathrm{~dB}$ ももの夫 1 耳宛である. $1.0 \mathrm{~dB}$ と1. $4 \mathrm{~dB}$ のものは1耳で, 純音斛值は $45 \mathrm{~dB}$ で ある。

1. $4 \mathrm{~dB}$ と1. $4 \mathrm{~dB}$ のものは1耳で，純音閵值は $30 \mathrm{~dB}$ ある。

1. $6 \mathrm{~dB}$ と $1.2 \mathrm{~dB}$ のものは1耳で, 純音閶值は $35 \mathrm{~dB}$ ある。

$1.6 \mathrm{~dB}$ と $1.4 \mathrm{~dB}$ ののは 1 耳で，純音闇值は $30 \mathrm{~dB}$ で ある。

$1.8 \mathrm{~dB}$ と $1.2 \mathrm{~dB}$ のものは 1 耳で，純音䦔值は $35 \mathrm{~dB}$ で ある。

閏值上 $30 \mathrm{~dB}$ で測定不能で䦯值上 $20 \mathrm{~dB}$ における DL 值 が0.8dBのもの1耳の純音喝値は60dBである。

2) $4 \mathrm{KC} の \mathrm{DL}$ 值

$0.6 \mathrm{~dB}$ と $0.6 \mathrm{~dB}$ のものは 2 耳で，純音䦪值は $25 \mathrm{~dB}$ と 30dBである。

$0.8 \mathrm{~dB}$ と0.6dB のものは 3 耳で，純音闒值は夫ヶ 45 $\mathrm{dB}, 50 \mathrm{~dB}, 55 \mathrm{~dB}$ ぐある

$0.8 \mathrm{~dB}$ と $0.8 \mathrm{~dB}$ のもの 3 耳で，純音關值は夫々 35 $\mathrm{dB}, 40 \mathrm{~dB}, 50 \mathrm{~dB}$ である。

$1.0 \mathrm{~dB}$ と0.8dBのものは 4 耳で，純简閶值は夫ヶ 30 $\mathrm{dB}, 35 \mathrm{~dB}, 40 \mathrm{~dB}, 50 \mathrm{~dB}$ あ゙あ.

$1.0 \mathrm{~dB}$ と $1.0 \mathrm{~dB} の も の は 4$ 耳で，純音閔值は夫々 15 $\mathrm{dB}, 30 \mathrm{~dB}, 35 \mathrm{~dB}, 40 \mathrm{~dB}$ である。

$1.2 \mathrm{~dB}$ と0.8dBのものは 1 耳で，純音䦪值は $35 \mathrm{~dB}$ で ある。

$1.2 \mathrm{~dB}$ と1.0dBのものは1耳で，純音闒值は $40 \mathrm{~dB}$ で 市。

1. $2 \mathrm{~dB}$ と $1.2 \mathrm{~dB}$ ののは 1 耳で，純音闒值は $45 \mathrm{~dB} て ゙$
ある。

1. $4 \mathrm{~dB}$ と $1.0 \mathrm{~dB} の 8$ の 2 耳で，純音閝值は $30 \mathrm{~dB}$ と $50 \mathrm{~dB}$ である。

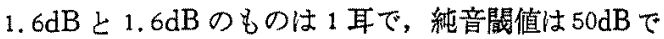
ある。

1. $6 \mathrm{~dB}$ と 1. $2 \mathrm{~dB}$ ののは 1 耳で, 純音閶值は $45 \mathrm{~dB} て ゙$ ある。

1. $6 \mathrm{~dB}$ と $1,6 \mathrm{~dB}$ ののは 1 耳で，純音䦪值は $35 \mathrm{~dB} て ゙$ 离。

1. $8 \mathrm{~dB}$ と1. $4 \mathrm{~dB}$ ののは 1 耳で, 純音䦔值は $50 \mathrm{~dB}$ ある。

次に閶值上 $30 \mathrm{~dB}$ で DL 值が測定できないものが 3 耳 ある.これらの䦭值上 $20 \mathrm{~dB} の \mathrm{DL}$ 值は $0.4 \mathrm{~dB} の も の 1$ 耳で純音閾值は6.5dB，0.8dBのもの1耳で，純音閶值は $70 \mathrm{~dB}, 1.0 \mathrm{~dB} の も 1$ 耳で純音閾值は65dBである。

以上からしで $1 \mathrm{KC}$ の閏值上 $20 \mathrm{~dB}$ と $30 \mathrm{~dB}$ における DL 值はす心゙て0.6dB と0. $6 \mathrm{~dB}$ 以上， $1.8 \mathrm{~dB} と 1.4 \mathrm{~dB}$ 以下で ある。

$4 \mathrm{KC}$ では純音閔值はすぶて上昇しており，閶值上 20 $\mathrm{dB}$ と30dBにおける DL 值はすべて0.6 $\mathrm{dB}$ と0.6 dB 以上 $1.8 \mathrm{~dB}$ と $1.6 \mathrm{~dB}$ 以下である。

小 括

老人性難恥耳では闑值上昇が高度の周波数は 1 つの周 波数に限らず，2〜3の周波数，あるいは，それ以上に 及ぶことが多い，そこで最大閖值の周波数と，最大關值

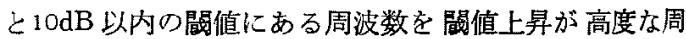
波数とした. しかして 2 周波数以上の場合で河れの周 波数に括いても White noise の強さを増すと純音閶值 が変化する場合と変化しない場合，あるいはある周波数 では変化して名他の周波数では変化しても他の周波数で は変化しない場合とがある。

すなわち, White noise を強くする毎に純音閵值が上 界する第1の型のもの6耳, White noise を強くしても 純音闘值が上界しない第 2 の型のむの13耳，この他に或 る周波数では第 1 の型で他の周波数では第 2 の型のもの ९耳である。

第 2 型を示す13耳の内, $\mathrm{A}$ 変化を示すものが 2 耳 Bの変化を示すものが 1 耳，Cの変化を示すものが 1 耳 $\mathrm{D}$ の変化を示すものはなくて，Eの変化を示すものが 4 耳である。

この他に $\mathrm{A}$ との変化が合併しているものが4耳，B と Eの変化が合併しているものが 1 耳である。

次に第 1 の型上第 2 の型が合併しているのは9耳であ 
る.この第 2 の型はAの変化を示すもの3，Eの変化を 示すもの 4, BとCの変化が合併しているもの1，Aと Eの変化が合併しているもの1である。

次に閏值上荠が高度の周波数附近の周波数に京ける White noise に上る闇值の变化をみるに，21R，21L，29 Lの3耳では純音閶值が各周波数で10dB以上の差暴がな いので対象となる周波数がない。

他の25耳では第 1 の型を示すもの18耳，第 2 型を示 すもの7耳である．第 2 の型ではAの変化のものが 4 耳 $\mathrm{B} の$ 変化, $\mathrm{C}$ 変化， $\mathrm{D} の$ 変化のものはなく，Eの变化 のものが 3 耳である。

次に老人性難聴耳の $1 \mathrm{KC} と 4 \mathrm{KC}$ の閣值上 $20 \mathrm{~dB}$ 己 $30 \mathrm{~dB}$ に衫ける DL 倠は次の如くである。

$1 \mathrm{KC}$ では閔值上 $20 \mathrm{~dB}$ と $30 \mathrm{~dB}$ における DL 值は夫々 $0.6 \mathrm{~dB}, 0.6 \mathrm{~dB}$ 加 $1.8 \mathrm{~dB}, 1.4 \mathrm{~dB} の$ 間にあり, 正常者 に括ける DL 值からみて中等傎の筙囲内にある。

$4 \mathrm{KC}$ で閶倠上 $20 \mathrm{~dB}$ と $30 \mathrm{~dB}$ における DL 值は夫々 $0.6 \mathrm{~dB}, 0.6 \mathrm{~dB}$ から $1.8 \mathrm{~dB}, 1.6 \mathrm{~dB}$ の間にありむこれを 正常者における DL 值と比較すると25耳が中等值の範囲 内にある。他の 3 耳 $(23 \mathrm{R}, 23 \mathrm{~L}, 28 \mathrm{R})$ では闇值上 $30 \mathrm{~dB}$

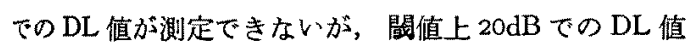
は夫ヶ $0.6 \mathrm{~dB}, 0.8 \mathrm{~dB}, 1.0 \mathrm{~dB}$ て，小の傾向はない。

しかして，DL值はすべて中等值であり，noise audiogram が第 1 の型のものは19R, 22L, 26R, 30L, 32R, 32 Lの6耳で, これらの4KCの noise audiogram も何れも 第1の型である。

次に noise audiogram が第 2 の型のむのは13耳であ る.これらのらち $4 \mathrm{KC} の$ noise audiogram が第 1 の型 のものは, 21L, 22R, 24R, 24L, 26L, 27R, 27L, 29R, $30 \mathrm{R} の 9 耳$ 耳゙あ，第 2 の型のものは 23R, 25R, 28R, 31Rの 4 耳である.

noise audiogram が第 1 の型と第2 の型を合併してい るものは 9 耳である、これらのうち $4 \mathrm{KC} の$ noise audiogram が第1の型のものは19L, 20R, 23L, 25L,29L, 31 Lの6耳であり，第 2 の型のものは $20 \mathrm{~L}, 21 \mathrm{R}, 28 \mathrm{~L} の 3$ 耳である。

これらの成績から DL 值はすべて中等值であり，4KC の noise audiogram が第1の型を示すものが 21 耳で, 第2の型を示子るのが 7 耳である。この7耳のDL 值は 中等値であるが，そのDL 值を仔細に検討すると，小さ 傾向にあるものは 1 耳のみで，大きい傾向のものが 2 耳である。

\section{第 4 章 総括並びに考按}

以上の成績を総括し，本検查法の蹦床的価值及び意義 について考察すると次のようである。

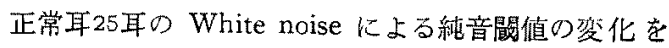
みるに, White noise 10dBから60dBまでの強さによる 各周波数の閾值の变化の平均值は第 1 図に示した如く で，各周波数の閶值の变化には多少の差異がみられる. すなわち125cps, 250cpsでは間值の変化は極めて少なく， White noise $60 \mathrm{~dB}$ の強さでも $15 \mathrm{~dB}$ から $20 \mathrm{~dB}$ の変化に 過ぎない.これに対して0.5KC，1KCでは $40 \mathrm{~dB} か ら 50$ $\mathrm{dB}$ 変化であり, $2 \mathrm{KC}, 3 \mathrm{KC}, 4 \mathrm{KC}, 6 \mathrm{KC}, 8 \mathrm{KC}$ では 50 $\mathrm{dB}$ から55dBの変化で，中音域から高音域においては閔 值の変化は大となつている。

この結果から White noise による闇値の変化を問題 とする本梌查法では闒值の変化が明らかで, White noise の強さを $10 \mathrm{~dB}$ 增寸每に闘值が明らかに変化してくる $1 \mathrm{KC}$ 以上の中，高音域に抬ける閏值の変化を検査するの が妥当であると考えられる。

そこで $1 \mathrm{KC}$ 以上の周波数に㧍ける閶值の変化を総括 するに, White noise $\operatorname{lodB}$ の強さでは純音闒值が変化 しない周波数が、つ以上あるのは19例であり，変化して いるのは6例に過ぎない。この結果からして, White noise $10 \mathrm{~dB}$ の強さ壮純音闒值の変化を検查する目的か らは適当であるとはいえない.

これに対して White noise $20 \mathrm{~dB}$ の強さではNo. 3， No. 4, No. 11, No. 13, No. 14, No. 17, No. 24 の 7 例 を除く18例に晾いて $1 \mathrm{KC}$ 以上の周波数で閶值は変化し ている.ささらに White noise $30 \mathrm{~dB}$ ではす心゙ての例にお いて $1 \mathrm{KC}$ 以上の周波数で閶值は変化している.

正常耳に㧍りる White noise による純音䦪值の変化 についての Langenbeck ${ }^{1)}$, Kietz ${ }^{(6)}$, Zangemeister ${ }^{3)}$, 立 木 $^{101}$ ，菊井 ${ }^{12)}$ らによる検查では White noiseの強さと純 音閶値の変化とは略比例的関係があるとされている.

私の成續では $1 \mathrm{KC}$ 以上の音域において White noise $10 \mathrm{~dB}$ では純音閾値が変化しない周波数のある例が25例 中19例あるが, White noise 20dB以上ではかかる例は 減少し 7 例に過ぎない，そして White noise $20 \mathrm{~dB}$ 以上 では 150 周波数中 127 周波数において White noiseの强 さを増す毎に純音閾值む変化し上昇しているので，本検 查法によつても両者の閏には比例的な關係があるとして もよいであろう。

しかし White noise 20dB以上に扔いて White noise の強さを増しても閏值が変化しない周波数のある症例は No. 2, No. 5 , No.6, No. 9 , No. 17, No. 18, No. 20, 
No.23の9例である。 その1例(No.23)の noise audiogram は第 2 図に示したが， $4 \mathrm{KC} ， 6 \mathrm{KC}, 8 \mathrm{KC}$ において 闒值の変化のない場合がみられる。

$こ の$ noise audiogram t平均值が示す noise audiogram 上比較するとWhite noise を強くしても閧值が必 らす上䒜してくるとはいえない、この上うに純音才ージ オグラムが正常值のときに White noiseの強さを増して も鼠值が上昇しない場合，又はWhite noise 負荷して も純音闌值が変化しない場合については，将来何らかの 型で曊われてくるであろら聴力異常を示晙する変化であ ると推察し，加る noise audiogram 老認めることによ つて内耳病変の準俑状態を知りうるのではなからうかと 若えられる。

次に検查する周波数について検討してみるに Langenbeck $^{15)}$ は $2 \mathrm{KC}$ 以下の音域では雑音の強さが強いと伝音 障書が発生し5る可能性があるから病的耳の考察の対象 としないこと述べている，私の行つた検査法による研究 成績から $0.5 \mathrm{KC}$ 以下の各周波数では $1 \mathrm{KC}$ 以上の音域の 周波数に比して純音閶值の変化が少ないので，純音閶值 の変化を検索するには $0.5 \mathrm{KC}$ 以下の低音域は適当でな いと考えられる。この事恃高音域に聴力障害の多い感音 難聴耳夌検查対象とする本検查法の臨床的応用から考え ると当然といえるであろう.

次に本検査法に上る成續の臨休診断的価傎を検討する ために片耳で行える閥傎上検查法の一つで, すでにある 程度の局所鑑別診断的価值の知られている DL Test に つレて. 判定基準を得るため閶值上10dBから60dBの強 さにおけるDL 值について検討した。

検查した周波数は中音域の代表として $1 \mathrm{KC}$ ，高音域の 代表しして $4 \mathrm{KCO} 2$ 周波数を選んだ。この2 周波数の閾 值上10dBから $60 \mathrm{~dB}$ における DL 值をみると，1KCでは

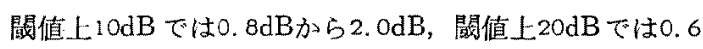
$\mathrm{dB}$ から 2.0dB，閔值上 $30 \mathrm{~dB}$ では。. $4 \mathrm{~dB}$ から $1.6 \mathrm{~dB}$, 閶 值上 $40 \mathrm{~dB}$ では0. $4 \mathrm{~dB}$ から $1.2 \mathrm{~dB}$, 䦔值上 $50 \mathrm{~dB}$ では 0.4 $\mathrm{dB}$ から1.2dB，䦪值上 $60 \mathrm{~dB}$ では0. $4 \mathrm{~dB}$ から1.0dBであ る。 $4 \mathrm{KC}$ では閾值上 $10 \mathrm{~dB}$ では $0.6 \mathrm{~dB}$ から $1.4 \mathrm{~dB}$ ，闒值

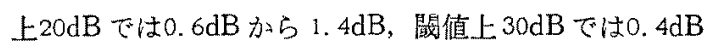
から $1.2 \mathrm{~dB}$, 闒值上 $40 \mathrm{~dB}$ では0. $4 \mathrm{~dB}$ から $1.0 \mathrm{~dB}$, 閾值上 $50 \mathrm{~dB}$ では0. $4 \mathrm{~dB}$ から0.8dB，閳值上60dB では0. $4 \mathrm{~dB}$ か ら0.6dBの間に夫々あり，DL 值は一定していない.

又測定する音の強さも閔值上何 $\mathrm{dB}$ のところで行うの が良いかといらことについても，一般には䦪值上10dB と30dB，あるいは $10 \mathrm{~dB}$ と $40 \mathrm{~dB}$ の強さで行われている
ものが多い．Lüscher ${ }^{18)}$ は閔值上 $40 \mathrm{~dB}$ を選んだ理由の 一つとして周波数による影響が殆んどないことと，容易 に脉音を判別し得ること挙げているが，もしこの強さ で測定できない場合には，この強さより10dB 又は $15 \mathrm{~dB}$ 弱い閾值上 $25 \mathrm{~dB}$ か $30 \mathrm{~dB}$ で行なつても根本的には変り ないとしている。

私の成績では閚值上10dB の DL 值に“ばらつき”が多 いことから脉音が判別し難いのであろらと思われ，又病 的耳では閶值上昇があり，閶值上 $40 \mathrm{~dB}$ で検查できない ことが少なくないと思われるので，Lüscher ${ }^{18)}$ のい5閶 值上 $25 \mathrm{~dB}$ と $30 \mathrm{~dB}$ では根本的に変化ないということ索 考にして，閝值上20dB と30dBの強さを選んだ。

一方得られた DL 值については，正常耳では研究者が 暴るとその方法も異なり，DL值も一定していないこと は, すでに知られているが，Lüscher ${ }^{18)}$ は䦪値上20dBで はおよそ1. $1 \mathrm{~dB}$ から1.6dB，閶值上 $40 \mathrm{~dB}$ ではおよそ0.9 $\mathrm{dB}$ から1.5dBとしており，立术 ${ }^{19}$ 柱最值上30dBで（1.5 土1.02) dBとしている. Liden, Nilson 22) らは䦪值上40 $\mathrm{dB}$ ではおよそ0. $5 \mathrm{~dB}$ から0.7dBの平均值を示している が，周波数により異なり，その限界值として最小值は $0.2 \mathrm{~dB}$ 加 $50.4 \mathrm{~dB}$, 最大值として1.1dB加ら $1.4 \mathrm{~dB}$ を示 している.

私の成績から, 簡值上 $20 \mathrm{~dB}$ と $30 \mathrm{~dB} の \mathrm{DL}$ 值をみると

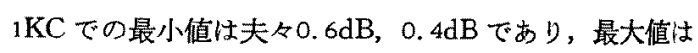
夫々 $2.0 \mathrm{~dB}, 1.6 \mathrm{~dB}$ である. $4 \mathrm{KC}$ での最小值は夫々0.6 $\mathrm{dB}, 0.4 \mathrm{~dB}$ であり，最大值は夫々 $1.4 \mathrm{~dB}, 1.2 \mathrm{~dB}$ あ゙る. この結果から，䦪值上20dBと $30 \mathrm{~dB} の \mathrm{DL}$ 值は夫々0.4 $\mathrm{dB}, 0.4 \mathrm{~dB}$ 以下のものを小とし, 夫ね $2.0 \mathrm{~dB}, 1.6 \mathrm{~dB}$ 以 上大とし、この両者の間の值を中等值としてもよいよ らに思われる。

しかし，両耳の DL 值の閒には差のないものが多く， $0.2 \mathrm{~dB}$ 差のものを含めると $\mathrm{KKC}$ では $80 \%$ 以上あり，4 $\mathrm{KC}$ では95\%もあることから，DL值の大小判断する には，個人差といらむのも考虑することが必要な場合も あるであろら。

论に病的耳について総括，考察してみる.

Langenbeck" は雑音による聴力の低下は伝音系の障 害によるむのではなく，中枢側の障害によるものである とした. そして雑音中の㯖力は絶対的なものではなく雑 音と純音を聞き判ける聴力の弁別能であるとし, 多くの 感音難㯖耳ではこの弁別能が障害されるため雃音中の聴 力が低下するとして雑音中の純音閶值を計る裕查法の診 断的意義を述べている。 
Huizing $^{3 !}$ は $1 \mathrm{KC}$ 純音の強さと大きさとの関係から感 音難聴耳では音の強さを増すと聴力が正常と同じように なることを知り、この現象を音が強さを增すと聴力が正 常と同じようになることを知り，この現象を音が强いと 難聴の程度が減少するとして，これを Regressicn と呼 び,この考えを Maskierungsaudiogramm に取り入れ， rein Rezeptionsschwerhörigkeit では Regression のた め音の強さを増すと正常耳の Maskierungsaudiogramm と同じよらになるが, Leitungsschwerhörigkit では正常 耳の Maskierungsaudiogramm と同じようにならないと 述バた。

1950年に至り Langenbeck ${ }^{4) 51}$ は内耳毛細胞の障害で は雑音中で検查した純音閶值は雑音のない時の純音關值 と変りないとした. すなわち弱い雑音の時だけ純音閶值 が変化しない場合と，雑音の強さがある程度の強さにな つても純音闇值が变化しない場合とがあるとし，更に聴 力損失の著明な高音域の周波数では雑音による純音琞值 の変化が全くなく，雑音のない時の繾音閣值と一致して いる場合もあるとした． Langenbeck は解剖学的な根拠 から，かかる変化は内耳毛細胞障害を示寸変化であると している、これに対して伍音系の障害では正常者と同じ 結果が得られるとしこれは内耳に達する雑音と純音の 関係が正常者と異ならないためであるとしている。

私の成績についてみると，慢性中耳炎による難㯖耳の White noise による䦙值の変化は, White noise の強さ を增す毎に閾值も変化する第 1 の型の変化を示してお り，純音閾值が上昇していても正常者の多くが示した変 化と同じで, White noise の強さが増して子䦪值が変化 しないものはなかつた。

次に騒音性難聴耳では，これに反し，White noise $の$ 強さが增しても闘值が変化しないことが常に認められ， 第2の型を示寸。

騒音性難聴耳の $4 \mathrm{KC}$ における第 2 の 型を分けると, 32耳中Aの変化のもの 5 耳, $\mathrm{B}$ 変化のもの7耳, $\mathrm{C} の$ 変化のもの14耳, Dの変化のもの2耳, Eの变化のもの 4耷しなる。

これら第 2 の型の変化とい5のは, Langenbeck ${ }^{5}$ が 内耳毛細胞の障害では，雑音中で検查した純音闒值は喖 音を負荷してない時の純音闘值と変らないというのと類 似した結果と思われる。そこで，第 2 の型の変化が内耳 毛細胞の障害と関連性を有するかを更に確めるために， DL值などから検討してみた。

これによると，間值上昇の明らかな $4 \mathrm{KC} の \mathrm{DL}$ 值は多
くのものが小である.しかして DL 值が小のものは内耳 毛細胞障害と考えられているので，これらの成績からも 第 2 の型のものは内耳毛細胞障害のものと考えられる。

しかし，No.15，16，17，1804例7耳では DL 值は 中等值を示している.この5ち No.15 では Fowler の Binaural Loudness Balance Test 代陽性を示しているこ とから内耳毛細胞障害と考光られるので, noise audiogram の型から推察される病変部位とDL 値などから推 察される病変部位の合致しないのは3例 6 耳のみとな b.

さらに，騒音による難聴耳では Corti 氏器に障害のあ ることは文献的にも明らかであり，Fowler $の$ Balance Test, DL 值共にまず妥当な成績を示しており, noise audiogram がすべて第 2 の型の変化を示すことから，第 2 の型の変化は Corti 氏器の障害を示唆する閣值の変化 であると考えられる。

次に騒音性難㯖耳と比較検討するのに病変部位が後迷 路にむむるとされている老人性難聴耳について考按する と，本症の闇值上昇が高度な周波数における White noise による閔值の変化を絋めると，第 10 型のもの6 耳, 第 20 型のもの13耳, 第1の型と第 20 型が合併し ているもの9耳である。

すなわ方老人性難㯖耳では闒值上昨が高度な周波数に おける White noise による橍值の変化には第 1 の型と 第2の型がみられる。

$\mathrm{DL}$ 値は $1 \mathrm{KC}, 4 \mathrm{KC}$ 共に閏值上 $20 \mathrm{~dB}, 30 \mathrm{cB}$ において, 正常耳の DL 值範囲内にある。

ここで老人性難聴耳の障害部位について文献的に考察 してみると Alexander は病変が Corti 氏器に原発し， 上行性に進展するとし, Habermann, Brühl は変性萎䁇 がCorti 氏器と神経線維に同時に現われるとし，Manasse は変性が㯖神経の中枢側から末稍へ進展するとい5. Saxen u. Fieandt は螺旋神経節細胞に変化を生ずる場合 とCorti 氏器に退行変性が蓄明である場合があるとい 5. Sporleder は迷路及び聴神経に病的変化を認め得な かつたことから病变は更に中枢にあるといら。

Saxen ${ }^{3+1}$ (1952) は螺旋神経節D老人性萎縮は単独で おこるが. Corti 氏器のみの疾患は稀で殆んどが螺旋神 経節細胞の萎縮走伴つているとした。

Fleischer ${ }^{351}$ は神経節細胞の消失は個人差はあるが， 年令と共に堌加し，明らかな生理的老化現象亡して認め られ，Corti 氏器の変化は年令や明らかな局在性がない ので，一部には死後の変化であり，一部には疾患による 
もので老人性の変化ではないとしている。

G. Pestalozza u. I. Shore ${ }^{\text {10) }}$ は組織学的に螺旋神経節 細胞と神経線維とが老人性難聴の最も一般的な障害部位 であるとしている。

Maurice, Saltzmann ${ }^{38)}$ は老人性難僡の主な病変は螺 旋神経節細胞の萎縮であり, 毛細胞の病变恃神経節細胞 の病変と平行しているという。

しかして老人性難聴の病変部位は後迷路性変化が主で あるが，多くの場合内耳毛細胞の障害も伴つていると考 えられる。

老人性難㯖の聴力については諸説があるが, Langenbeck $^{51}$ によると初期の老人性難㯖では雑音による䦪値の 変化はみられないが，可成り焦行した老人性難德では高 音域で閔值上昇が高度な周波数に扔いて雑音による關值 の変化がみられるとしている。

Fleischer ${ }^{351}$ は Langenbeck $の$ Geräuschaudiometrie を行い，後迷路型を示すのは病的遮蔽現象のた放，雑音 による純音閖值の変化が明らをにおこり，特に高令者に 多いとしている，しかし少数例では雑音による純音閔值 の変化がない毛細胞型のものがあり，時に両者の混合型 があつたと述べている。

私の成績では老人性難聴耳の White noise に上る純 音閣値の変化には第 1 の型のものと第 2 の型のものがあ り，更に第 1 の型と第 2 の型が合併している例があり, 先述した諸家の成績の如く一定していない。

老人性難聴耳で第 2 の型を示して Corti 氏器病変の疑 われる症例について考察するに，かかる症例では Kurt， Jatho u. K. Heinz $z^{42)}$ らのいう如く老人性難聴は長い間 に受けた音の刺戟による生理的な結果であるといらこと む考えられるし, Fleischer ${ }^{35 j}$ や Pestalozza ${ }^{401}$ らのいう 如く病変が Corti 氏器に波及した結果であるらとも考え られる。

DL Test そついては Maurice. Saltzmann ${ }^{38 !}$ は老人 性難聴耳の DL 值は著明な減少はしないとしている。 Fleischer ${ }^{35}$ )は DL 值が0.5dB以下のものはないとした。 G. Pestalozza u. I. Shore ${ }^{+0)}$ はDL Test だけでは病的

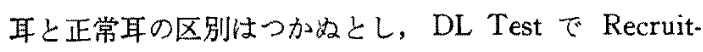
ment 現象を示した少数例の老人性難聴については病変 が中枢側から Corti 氏器の毛細胞に波及したもので，老 化現象の一過程によるものとした。

私の DL Test の成績で注老人性難㯖耳の全例が闎值 上 $20 \mathrm{~dB}, 30 \mathrm{~dB}$ での $\mathrm{DL}$ 值は $1 \mathrm{KC}, 4 \mathrm{KC}$ 共に正常耳の範 囲内で著明な減少はみられない。
しかし騒音性難聴耳で DL 值が中等値の 7 例がある如 く，又 Hirsh ${ }^{23)}$ P Pestalozza ${ }^{401}$ のいら如く，DL 值だけ でその病変部位を推定するのは困難な場合がある，従つ て noise audiometry の方が DL Testよりは病変部位 を一層明確に示してくれるものと思われる。

従つて老人性難㯖に括いて第二の型を示す場合柱騒音 性難聴耳の成積から，その病変部位は Corti 氏器である らと推考され，第 1 の型の場合は Corti 氏器以外で，层 音系老除くその他の部位に病変があるものと推考され る. 又第 1 の型と第 2 の型が合併している例では Fleis. cher ${ }^{35)}$ のいう混合型を考えるのが妥当と思われる。

次に闒值上昇が高度な周波数付近の周波数において， White noise による閶値の変化で問題となるのは小括で 記した如く，純音關值が正常籍囲内にあるにも拘らず， 第 2 の型を示す $5 \mathrm{R} の 6 \mathrm{KC}$ の如き場合である，

第 2 の型注通常 閶值上昇が高度な周波数沈おいてみ られる事が多いのに，5Rの6KCでは純音闇值が正常䈥 囲内にあるのに第2の型を示したことに対し次のような 考察が行なえる.

すなわち，4KCでは第 2 の型を示しているので障害 が $4 \mathrm{KC}$ から $6 \mathrm{KC}$ にまで進みつつあることが疑われる。

この6KCの閥值の変化は，以ずれ聴力障害が顕われ るであろうことを示唆し，現在その準備状態にあるもの と思放れる。

このような変化は正常耳においてもみられたもので， 本検查法が，かかる潜在的な聴力異常をみ出しらる可能 性を有しているものと考えられる.

\section{第 5 章 結 語}

正常耳25耳, 慢性中耳炎による伝音系難㯖耳 21 耳, 騒 音性難聴耳 32 耳, 老人性難聴耳28耳について, White noise による閖值の変化と DL 值を検査し, 次の結果を 得た。

1）正常耳に扔いて本検查法による White noise によ る閔値の変化は0.5KC以下の音域では闇值の变化を示 すものが少なく，1KC以上の音域では閥值の変化を示 すものが多いので, 感音難㯖耳を検査寸るには適当で あると思われる。

2）閾值の変化を検查するに, White noise $10 \mathrm{~dB}$ の强 さの負荷では闇值が変化するものが少なく, White noise 20dB以上の强さになると, 多くのものが閶値の 変化を示すので, 臨床的に White noise $30 \mathrm{~dB}$ 以上の 強さで検査を行うのが適当であるうと思われる。そし て White noise の強さを增す毎に關値が変化するも 
のを第 1 の型の变化とした.

3) しかし, 純音閔值が正常範囲内にあつても, White noise の强さが増す每に 純音閏值が常に変化するもの ばかりでなく、White noise の強さが增しても純音闇 值が変化しないものが少数みられた。

かかる変化は White noise を負荷することにより 戝われた潜在性の㯖力異常であると考えられ，聴力障 害が㩆現される準備状態にあるものと推察される。

4） DL 值は閔值上 $20 \mathrm{~dB} ， 30 \mathrm{~dB}$ の值を採用しても，西 る程度まで障害部位の鑑別䛦断の目的は達せられる が，個人について左右耳の DL 值の間には差がないも のが多いので，DL值を判別するに性人差という因 子も考慮するのが望ましい。

5) 騒音性難聴耳では閵値上昇が高度な周波数におい て, White noise による間值の変化は全例が White noise の強さを增しても，ある强さまで闘值が変化し ない.この闞值の変化を第 2 の型の変化とした。

6) 老人性難聴耳では闘值上昇が高度な周波数にお、 て，第 1 の型だけ示するの，第 2 の型だけ示するの， 第 1 の型と第 2 の型が合併しているものがある.

7) White noise による閥值の変化とDL值の関保は, DL 值学闇值上 $20 \mathrm{~dB}, 30 \mathrm{~dB}$ の DL 值学榇用し，0.4dB 以下を小として記すと次のようである。

慢性中耳炎による伝音系難聴耳では全例が第 1 の型 だけ示し，DL 值は全例が中等值を示している.

騒音性難㯖耳では全例が第 2 の型だけ示し，DL 值 は小のものと中等值を示すものがある。

老人性難聴耳では第 1 の型だけ示するのと，第 $2 の$ 型だけ示すものと，第1の型上第 2 の型が合併してい るものがあり，DL 值は全例が中等值を示している．

8）本検查法の結果と障害部位との関倸は, 騷音性難徳 耳の結果及び Fowler の Binaural Loudness Balance Test の結果からして，第 2 の型は Corti 氏器の障害 上関連性があるものと思われ，老人性難聴耳の結果か ら第 1 の型注後迷路性の障害が疑われる。

\section{附 表 \\ 第 1 表 (1)}

\begin{tabular}{|c|c|c|c|c|c|c|c|c|c|c|}
\hline \multirow{3}{*}{ No. } & \multicolumn{4}{|c|}{ Noise } & \multicolumn{6}{|c|}{ Audiometry } \\
\hline & \multirow{2}{*}{$\begin{array}{c}\text { 雑音の } \\
\text { 強さ } \\
\mathrm{db} \\
\text { (阀值上) }\end{array}$} & \multicolumn{4}{|c|}{ 闒 } & $\infty$ & 変 & 化 & & \\
\hline & & 125 & 250 & 500 & $1 \mathrm{~K}$ & $2 \mathrm{~K}$ & $3 \mathrm{~K}$ & $4 \mathrm{~K}$ & $6 \mathrm{~K}$ & $8 \mathrm{~K}$ \\
\hline \multirow{6}{*}{1} & +10 & 5 & 0 & 0 & 0 & 5 & 10 & 0 & 10 & 5 \\
\hline & 20 & 5 & 5 & 0 & 5 & 10 & 15 & 5 & 15 & 10 \\
\hline & 30 & 10 & 10 & 5 & 15 & 20 & 20 & 15 & 20 & 20 \\
\hline & 40 & 10 & 10 & 20 & 20 & 25 & 30 & 25 & 35 & 30 \\
\hline & 50 & 10 & 15 & 20 & 35 & 40 & 50 & 45 & 45 & 45 \\
\hline & 60 & 15 & 30 & 40 & 45 & 50 & 55 & 50 & 55 & 55 \\
\hline \multirow{6}{*}{2} & +10 & 0 & 0 & 0 & 0 & 5 & 5 & 5 & 10 & 0 \\
\hline & 20 & 5 & 0 & 0 & 5 & 20 & 15 & 5 & 15 & 5 \\
\hline & 30 & 10 & 0 & 5 & 10 & 25 & 25 & 5 & 25 & 15 \\
\hline & 40 & 20 & 5 & 20 & 15 & 30 & 30 & 30 & 40 & 20 \\
\hline & 50 & 20 & 15 & 20 & 35 & 45 & 45 & 40 & 50 & 35 \\
\hline & 60 & 20 & 25 & 40 & 45 & 55 & 55 & 50 & 60 & 50 \\
\hline \multirow{6}{*}{3} & +10 & 0 & 0 & 0 & 0 & 0 & 10 & 15 & 5 & -5 \\
\hline & 20 & 0 & 0 & 0 & 10 & 10 & 15 & 15 & 5 & 0 \\
\hline & 30 & 0 & 0 & 5 & 15 & 20 & 25 & 25 & 10 & 5 \\
\hline & 40 & 0 & 5 & 15 & 30 & 30 & 35 & 40 & 30 & 20 \\
\hline & 50 & 5 & 10 & 15 & 40 & 40 & 45 & 50 & 40 & 30 \\
\hline & 60 & 10 & 20 & 40 & 50 & 55 & 60 & 65 & 50 & 45 \\
\hline \multirow{6}{*}{4} & +10 & 0 & -5 & -5 & 0 & 0 & 5 & 5 & 5 & 5 \\
\hline & 20 & 0 & -5 & 0 & 0 & 5 & 10 & 10 & 10 & 5 \\
\hline & 30 & 0 & 0 & 5 & 10 & 10 & 15 & 20 & 15 & 15 \\
\hline & 40 & 5 & 0 & 15 & 25 & 25 & 30 & 20 & 30 & 20 \\
\hline & 50 & 10 & 15 & 30 & 25 & 35 & 40 & 35 & 40 & 40 \\
\hline & 60 & 10 & 20 & 35 & 45 & 45 & 55 & 55 & 55 & 50 \\
\hline & +10 & 0 & -5 & 0 & 5 & 5 & 15 & 15 & 20 & 5 \\
\hline & 20 & -5 & -5 & 5 & 10 & 15 & 20 & 30 & 35 & 10 \\
\hline & 30 & 0 & 0 & 15 & 15 & 20 & 30 & 35 & 35 & 20 \\
\hline & 40 & 10 & 10 & 15 & 30 & 30 & 40 & 45 & 45 & 25 \\
\hline & 50 & 10 & 10 & 30 & 35 & 45 & 45 & 55 & 55 & 30 \\
\hline & 60 & 10 & 20 & 40 & 45 & 55 & 60 & 70 & 70 & 50 \\
\hline
\end{tabular}


(2)

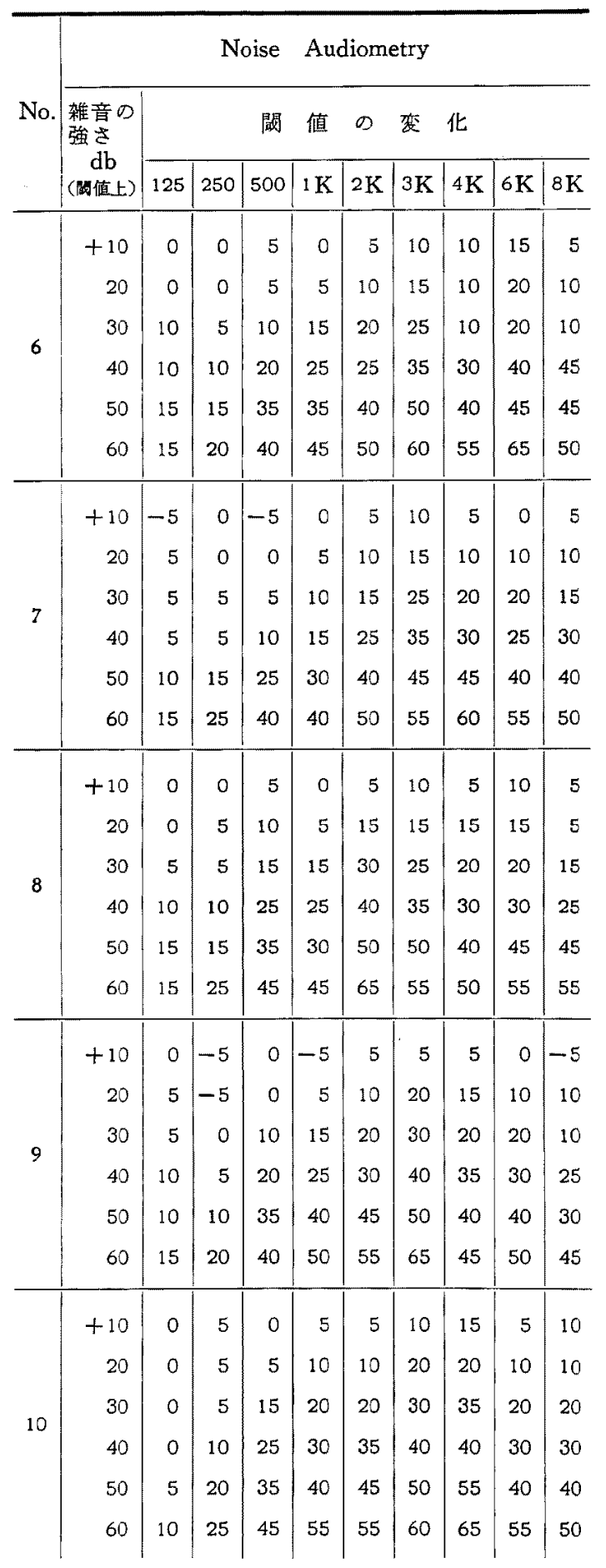

(3)

\begin{tabular}{|c|c|c|c|c|c|c|c|c|c|c|}
\hline \multirow{3}{*}{ No. } & \multicolumn{4}{|c|}{ Noise } & \multicolumn{3}{|c|}{ Audiometry } & & & \\
\hline & \multirow{2}{*}{ 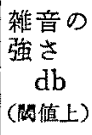 } & \multicolumn{3}{|r|}{ 閶 } & 值 & $\infty$ & 变 & 化 & & \\
\hline & & 125 & 250 & 500 & $1 \mathrm{~K}$ & $2 \mathrm{~K}$ & $3 \mathrm{~K}$ & $4 \mathrm{~K}$ & $6 \mathrm{~K}$ & $8 \mathrm{~K}$ \\
\hline \multirow{6}{*}{11} & +10 & 0 & 0 & 0 & 0 & 10 & 10 & 5 & 0 & 0 \\
\hline & 20 & 0 & 0 & 5 & 5 & 15 & 15 & 10 & 10 & 0 \\
\hline & 30 & 10 & 5 & 15 & 10 & 25 & 25 & 25 & 25 & 10 \\
\hline & 40 & 15 & 10 & 25 & 25 & 35 & 30 & 35 & 50 & 30 \\
\hline & 50 & 25 & 25 & 35 & 30 & 50 & 45 & 45 & 55 & 40 \\
\hline & 60 & 40 & 35 & 45 & 50 & 60 & 60 & 65 & 55 & 50 \\
\hline \multirow{6}{*}{12} & +10 & -5 & -5 & 0 & 0 & 10 & 15 & 10 & 5 & 15 \\
\hline & 20 & 0 & 0 & 0 & 5 & 15 & 20 & 20 & 10 & 25 \\
\hline & 30 & 5 & 0 & 10 & 10 & 20 & 25 & 25 & 15 & 30 \\
\hline & 40 & 5 & 10 & 15 & 15 & 30 & 40 & 35 & 25 & 35 \\
\hline & 50 & 5 & 10 & 30 & 25 & 40 & 50 & 50 & 35 & 45 \\
\hline & 60 & 10 & 25 & 40 & 35 & 55 & 60 & 60 & 45 & 55 \\
\hline \multirow{6}{*}{13} & +10 & -5 & 0 & o & 0 & 5 & 5 & 10 & 5 & 15 \\
\hline & 20 & 0 & 0 & 0 & 0 & 10 & 10 & 15 & 15 & 20 \\
\hline & 30 & 0 & 0 & 5 & 5 & 20 & 15 & 30 & 25 & 25 \\
\hline & 40 & 15 & 5 & 15 & 15 & 25 & 30 & 35 & 30 & 35 \\
\hline & 50 & 15 & 10 & 25 & 30 & 35 & 35 & 50 & 40 & 45 \\
\hline & 60 & 25 & 15 & 30 & 35 & 40 & 50 & 55 & 45 & 55 \\
\hline \multirow{6}{*}{14} & +10 & 5 & 5 & 5 & 5 & -5 & 15 & 5 & 10 & 0 \\
\hline & 20 & 10 & 5 & 0 & 10 & 0 & 20 & 10 & 15 & 0 \\
\hline & 30 & 10 & 5 & 5 & 15 & 5 & 30 & 20 & 25 & 5 \\
\hline & 40 & 10 & 10 & 5 & 25 & 15 & 35 & 30 & 30 & 15 \\
\hline & 50 & 15 & 10 & 20 & 35 & 25 & 45 & 35 & 40 & 20 \\
\hline & 60 & 15 & 15 & 30 & 35 & 25 & 45 & 40 & 50 & 30 \\
\hline \multirow{6}{*}{1} & +10 & 0 & -5 & 5 & 0 & 5 & 5 & 5 & 0 & 0 \\
\hline & 20 & 5 & 0 & 5 & 5 & 15 & 10 & 10 & 5 & 5 \\
\hline & 30 & 5 & 5 & 10 & 15 & 20 & 20 & 20 & 15 & 15 \\
\hline & 40 & 15 & 0 & 25 & 25 & 35 & 30 & 30 & 25 & 25 \\
\hline & 50 & 15 & 5 & 35 & 40 & 40 & 35 & 40 & 35 & 35 \\
\hline & 60 & 10 & 20 & 45 & 50 & 55 & 45 & 55 & 45 & 40 \\
\hline
\end{tabular}


(4)

Noise Audiometry

No. 雑音の

強き

閎 值 の 变 化

\begin{tabular}{c|c|c|c|c|c|c|c|c|c|}
$\mathrm{db}$ \\
\hline (㽣艋上) & 125 & 250 & 500 & $1 \mathrm{~K}$ & $2 \mathrm{~K}$ & $3 \mathrm{~K}$ & $4 \mathrm{~K}$ & $6 \mathrm{~K}$ & $8 \mathrm{~K}$ \\
\hline
\end{tabular}

\begin{tabular}{|l|l|l|l|l|l|l|l|l|l}
+10 & -5 & 5 & 5 & 5 & 5 & 15 & 10 & 10 & 5
\end{tabular}

\begin{tabular}{l|l|l|l|l|l|l|l|l|l|l}
20 & -5 & 5 & 5 & 15 & 10 & 20 & 15 & 15 & 5
\end{tabular}

16

\begin{tabular}{llllll|l|l|l|l|l}
30 & 0 & 10 & 15 & 20 & 20 & 30 & 30 & 20 & 15
\end{tabular}

\begin{tabular}{l|l|l|l|l|l|l|l|l|l}
40 & 0 & 10 & 25 & 30 & 25 & 35 & 35 & 30 & 25
\end{tabular}

\begin{tabular}{lll|l|l|l|l|l|l|l|l}
50 & 5 & 20 & 30 & 40 & 40 & 40 & 50 & 40 & 30
\end{tabular}

\begin{tabular}{l|l|l|l|l|l|l|l|l|l|}
60 & 5 & 25 & 40 & 50 & 50 & 55 & 60 & 50 & 45
\end{tabular}

\begin{tabular}{|c|c|c|c|c|c|c|c|c|c|c|}
\hline \multirow{6}{*}{17} & +10 & 0 & 0 & 5 & 0 & -5 & 5 & 10 & 0 & 0 \\
\hline & 20 & 0 & 0 & 5 & 10 & 5 & 10 & 10 & 10 & 0 \\
\hline & 30 & 0 & 0 & 5 & 15 & 5 & 20 & 20 & 15 & 10 \\
\hline & 40 & 10 & 5 & 10 & 20 & 25 & 30 & 30 & 25 & 20 \\
\hline & 50 & 10 & 10 & 25 & 30 & 30 & 35 & 40 & 30 & 35 \\
\hline & 60 & 15 & 15 & 40 & 45 & 45 & 45 & 55 & 45 & 40 \\
\hline \multirow{6}{*}{18} & +10 & 0 & 5 & 5 & 5 & 10 & 5 & 0 & 10 & 10 \\
\hline & 20 & 5 & 10 & 5 & 10 & 15 & 10 & 10 & 10 & 15 \\
\hline & 30 & 5 & 10 & 5 & 20 & 15 & 20 & 20 & 20 & 15 \\
\hline & 40 & 10 & 10 & 10 & 25 & 25 & 25 & 30 & 35 & 25 \\
\hline & 50 & 15 & 15 & 20 & 35 & 35 & 35 & 35 & 40 & 35 \\
\hline & 60 & 15 & 20 & 25 & 45 & 45 & 50 & 50 & 50 & 45 \\
\hline \multirow{6}{*}{19} & +10 & 0 & -5 & -5 & 10 & 5 & 10 & 15 & 10 & 15 \\
\hline & 20 & 0 & -5 & 0 & 20 & 15 & 20 & 25 & 20 & 15 \\
\hline & 30 & 5 & 0 & 15 & 30 & 20 & 30 & 35 & 30 & 25 \\
\hline & 40 & 5 & 5 & 25 & 35 & 35 & 35 & 45 & 40 & 35 \\
\hline & 50 & 5 & 10 & 30 & 45 & 40 & 40 & 50 & 50 & 45 \\
\hline & 60 & 10 & 15 & 35 & 55 & 55 & 55 & 65 & 60 & 55 \\
\hline \multirow{6}{*}{20} & +10 & 0 & 5 & 0 & 10 & 5 & 5 & 10 & 5 & 10 \\
\hline & 20 & 0 & 5 & 5 & 10 & 10 & 10 & 20 & 20 & 15 \\
\hline & 30 & 0 & 5 & 10 & 15 & 15 & 20 & 30 & 20 & 20 \\
\hline & 40 & 0 & 10 & 20 & 25 & 20 & 25 & 40 & 35 & 30 \\
\hline & 50 & 5 & 10 & 30 & 35 & 35 & 35 & 50 & 40 & 40 \\
\hline & 60 & 15 & 20 & 30 & 50 & 40 & 45 & 60 & 60 & 55 \\
\hline
\end{tabular}

(5)

Noise Audiometry

強

\begin{tabular}{c|c|c|c|c|c|c|c|c|c|} 
(匍值上) & 125 & 250 & 500 & $1 \mathrm{~K}$ & $2 \mathrm{~K}$ & $3 \mathrm{~K}$ & $4 \mathrm{~K}$ & $6 \mathrm{~K}$ & $8 \mathrm{~K}$ \\
\hline
\end{tabular}

\begin{tabular}{|l|l|l|l|l|l|l|l|l|l}
+10 & 10 & 5 & 5 & 0 & 10 & 10 & 5 & 5 & 5
\end{tabular}

\begin{tabular}{|l|l|l|l|l|l|l|l|l|l}
20 & 15 & 5 & 5 & 10 & 15 & 20 & 10 & 15 & 10
\end{tabular}

\begin{tabular}{l|l|l|l|l|l|l|l|l|l|}
30 & 20 & 5 & 10 & 15 & 25 & 25 & 20 & 25 & 15
\end{tabular}

\begin{tabular}{l|l|l|l|l|l|l|l|l|l|}
40 & 25 & 10 & 25 & 25 & 35 & 35 & 30 & 35 & 30
\end{tabular}

\begin{tabular}{l|l|l|l|l|l|l|l|l|l|l}
50 & 25 & 15 & 35 & 35 & 45 & 50 & 40 & 45 & 40
\end{tabular}

\begin{tabular}{l|l|l|l|l|l|l|l|l|l|}
60 & 25 & 25 & 45 & 45 & 55 & 60 & 55 & 55 & 55
\end{tabular}

\begin{tabular}{|l|l|l|l|l|l|l|l|l|l}
+10 & 5 & 0 & 0 & 5 & 10 & 10 & 5 & 0 & 5
\end{tabular}

\begin{tabular}{l|l|l|l|l|l|l|l|l|l|l}
20 & 5 & 0 & 0 & 5 & 10 & 15 & 5 & 10 & 5
\end{tabular}

\begin{tabular}{l|l|l|l|l|l|l|l|l|l}
30 & 15 & 5 & 10 & 10 & 20 & 20 & 20 & 20 & 15
\end{tabular}

\begin{tabular}{|l|l|l|l|l|l|l|l|l|l|l}
40 & 20 & 10 & 20 & 20 & 30 & 30 & 25 & 30 & 20
\end{tabular}

\begin{tabular}{|l|l|l|l|l|l|l|l|l|l|l}
50 & 20 & 15 & 25 & 30 & 40 & 40 & 35 & 40 & 35
\end{tabular}

\begin{tabular}{l|l|l|l|l|l|l|l|l|l|}
60 & 25 & 20 & 40 & 40 & 50 & 55 & 50 & 55 & 45
\end{tabular}

\begin{tabular}{l|l|l|l|l|l|l|l|l|l}
\hline+10 & 0 & 5 & 5 & 5 & 5 & 10 & 10 & 10 & 5
\end{tabular}

\begin{tabular}{l|l|l|l|l|l|l|l|l|l}
20 & 0 & 5 & 5 & 10 & 10 & 15 & 10 & 15 & 10
\end{tabular}

\begin{tabular}{l|l|l|l|l|l|l|l|l|l}
30 & 10 & 10 & 10 & 20 & 20 & 25 & 10 & 15 & 10
\end{tabular}

23

\begin{tabular}{l|l|l|l|l|l|l|l|l|l}
40 & 10 & 15 & 20 & 30 & 25 & 35 & 30 & 35 & 45
\end{tabular}

\begin{tabular}{l|l|l|l|l|l|l|l|l|l}
50 & 15 & 20 & 35 & 40 & 40 & 50 & 40 & 40 & 45
\end{tabular}

\begin{tabular}{lll|l|l|l|l|l|l|l|l}
60 & 15 & 25 & 40 & 50 & 50 & 60 & 55 & 60 & 50
\end{tabular}

\begin{tabular}{|c|c|c|c|c|c|c|c|c|c|c|}
\hline \multirow{6}{*}{24} & +10 & 0 & -5 & -5 & 0 & 0 & 5 & 5 & 5 & 5 \\
\hline & 20 & 0 & -5 & 0 & 0 & 5 & 10 & 10 & 10 & 5 \\
\hline & 30 & 0 & 0 & 5 & 10 & 10 & 15 & 20 & 15 & 15 \\
\hline & 40 & 5 & 0 & 15 & 25 & 25 & 30 & 25 & 30 & 20 \\
\hline & 50 & 10 & 15 & 30 & 25 & 35 & 40 & 35 & 40 & 40 \\
\hline & 60 & 10 & 20 & 35 & 45 & 45 & 55 & 55 & 55 & 50 \\
\hline \multirow{6}{*}{25} & +10 & 0 & -5 & 5 & 5 & 5 & 15 & 5 & 10 & 0 \\
\hline & 20 & 5 & 0 & 5 & 10 & 10 & 20 & 15 & 20 & 5 \\
\hline & 30 & 10 & 5 & 15 & 15 & 20 & 30 & 20 & 30 & 15 \\
\hline & 40 & 10 & 10 & 25 & 25 & 30 & 35 & 30 & 40 & 30 \\
\hline & 50 & 10 & 15 & 30 & 35 & 40 & 45 & 35 & 50 & 35 \\
\hline & 60 & 15 & 20 & 40 & 45 & 55 & 60 & 55 & 60 & 55 \\
\hline
\end{tabular}


第 2 表 正常耷

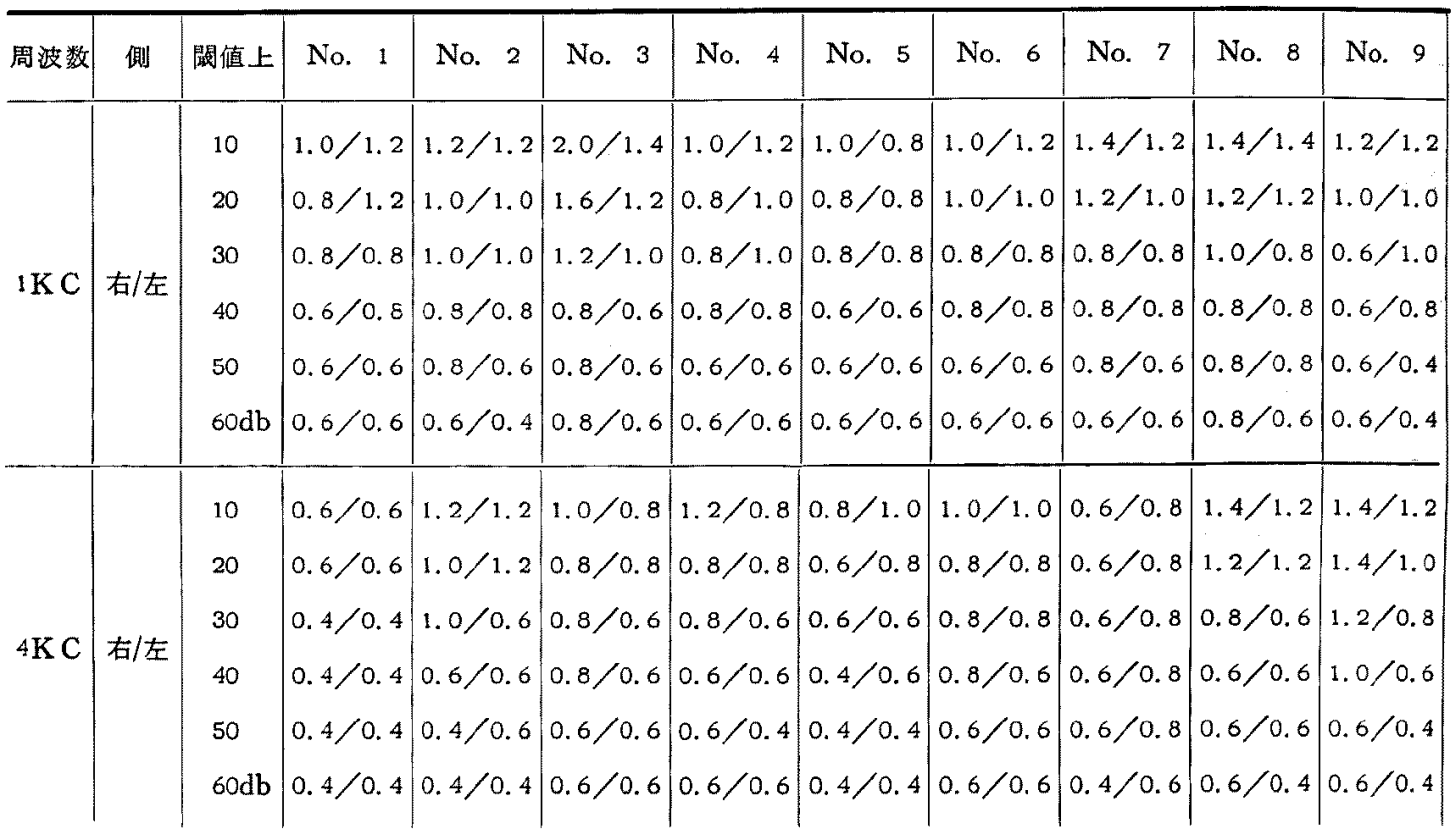

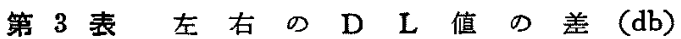

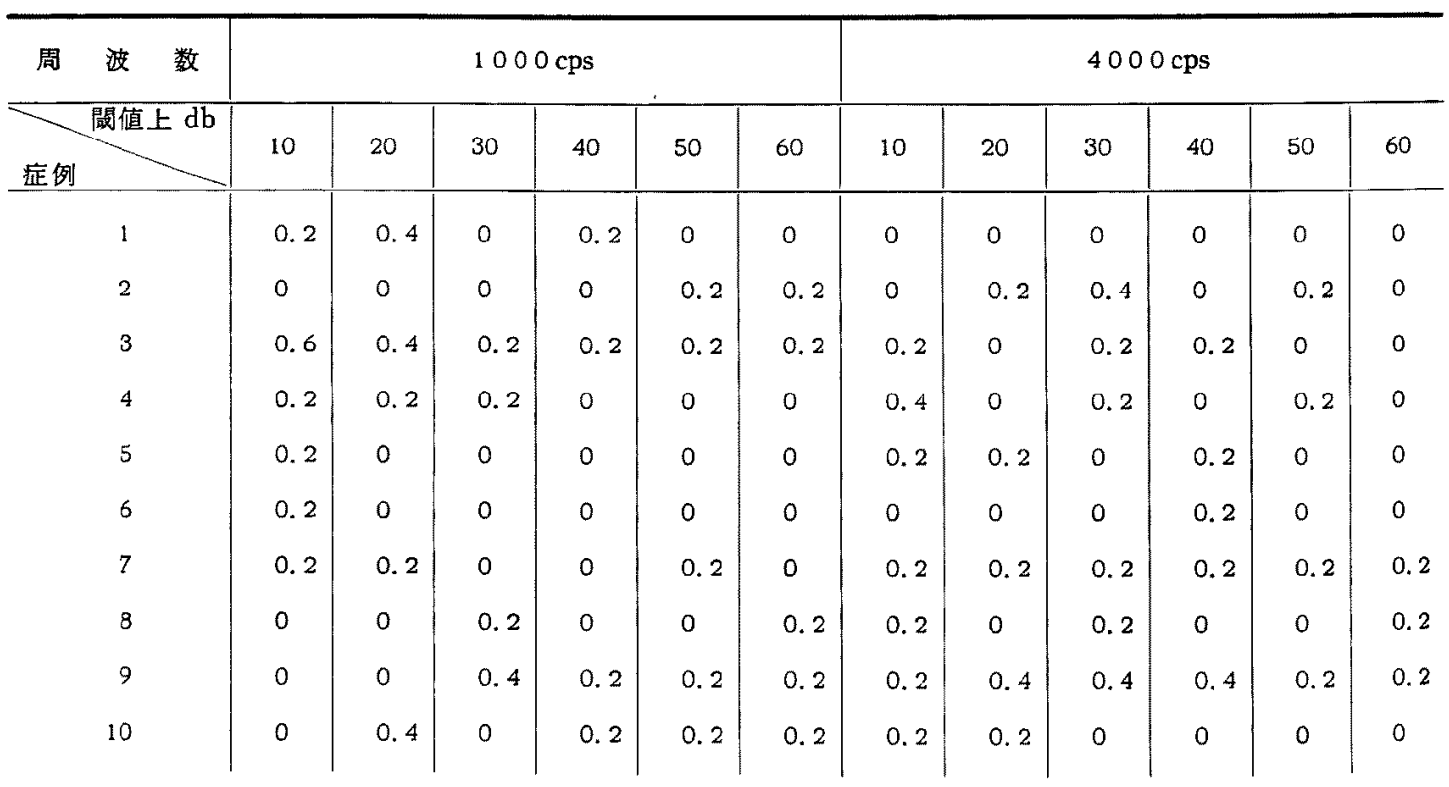


の D L 值

\begin{tabular}{l|l|l|l|l|l|l|l|l|l|l|}
\hline No.10 & No.11 & No. 12 & No. 13 & No.14 & No.15 & No. 16 & No.17 & No. 18 & No. 19 & No. 20 \\
\hline $1.8 / 1.8$ & $1.4 / 1.2$ & $1.2 / 1.4$ & $1.2 / 0.8$ & $2.0 / 1.0$ & $1.0 / 0.8$ & $1.4 / 1.8$ & $1.2 / 1.0$ & $1.8 / 2.0$ & $1.0 / 1.0$ & $1.2 / 1.2$ \\
$1.8 / 1.4$ & $1.2 / 1.2$ & $1.0 / 1.2$ & $1.0 / 0.6$ & $1.8 / 1.0$ & $1.0 / 0.6$ & $1.2 / 1.6$ & $1.2 / 0.6$ & $1.6 / 2.0$ & $0.8 / 1.0$ & $1.2 / 1.0$ \\
$1.2 / 1.2$ & $1.0 / 1.0$ & $0.8 / 0.6$ & $1.0 / 0.4$ & $1.4 / 0.8$ & $0.6 / 0.6$ & $1.0 / 1.4$ & $1.0 / 0.6$ & $1.0 / 1.6$ & $0.6 / 0.8$ & $1.0 / 0.8$ \\
\hline $1.0 / 0.8$ & $0.6 / 0.8$ & $0.6 / 0.4$ & $0.8 / 0.4$ & $1.2 / 0.6$ & $0.6 / 0.4$ & $1.0 / 1.2$ & $0.8 / 0.6$ & $0.8 / 1.0$ & $0.6 / 0.6$ & $0.6 / 0.8$ \\
$1.0 / 0.8$ & $0.6 / 0.6$ & $0.6 / 0.4$ & $0.6 / 0.4$ & $1.2 / 0.4$ & $0.6 / 0.4$ & $1.0 / 1.0$ & $0.6 / 0.4$ & $0.8 / 1.0$ & $0.6 / 0.6$ & $0.4 / 0.6$ \\
$0.4 / 0.6$ & $0.4 / 0.6$ & $0.6 / 0.4$ & $0.4 / 0.4$ & $1.0 / 0.4$ & $0.4 / 0.4$ & $1.0 / 1.0$ & $0.6 / 0.4$ & $0.6 / 0.8$ & $0.6 / 0.4$ & $0.6 / 0.6$ \\
\hline $1.0 / 1.2$ & $0.8 / 1.0$ & $0.8 / 1.0$ & $1.0 / 0.8$ & $1.2 / 1.2$ & $1.0 / 0.8$ & $0.8 / 1.0$ & $1.0 / 1.0$ & $1.2 / 1.2$ & $0.8 / 0.8$ & $1.0 / 1.0$ \\
$0.8 / 1.0$ & $0.8 / 0.8$ & $0.6 / 0.8$ & $0.8 / 0.8$ & $1.0 / 1.0$ & $1.0 / 0.8$ & $0.8 / 1.0$ & $1.0 / 0.8$ & $1.0 / 1.0$ & $0.8 / 0.6$ & $1.0 / 0.8$ \\
$0.8 / 0.8$ & $0.6 / 0.8$ & $0.6 / 0.6$ & $0.8 / 0.6$ & $0.8 / 1.0$ & $0.8 / 0.6$ & $0.4 / 0.8$ & $0.8 / 0.6$ & $0.8 / 1.0$ & $0.6 / 0.6$ & $0.8 / 0.8$ \\
$0.8 / 0.8$ & $0.6 / 0.6$ & $0.4 / 0.4$ & $0.6 / 0.6$ & $0.8 / 0.8$ & $0.4 / 0.4$ & $0.4 / 0.6$ & $0.6 / 0.4$ & $0.6 / 0.6$ & $0.4 / 0.4$ & $0.6 / 0.6$ \\
$0.6 / 0.6$ & $0.4 / 0.6$ & $0.4 / 0.4$ & $0.4 / 0.4$ & $0.6 / 0.6$ & $0.4 / 0.4$ & $0.4 / 0.6$ & $0.4 / 0.4$ & $0.4 / 0.4$ & $0.4 / 0.4$ & $0.4 / 0.6$ \\
$0.6 / 0.6$ & $0.4 / 0.4$ & $0.4 / 0.4$ & $0.4 / 0.4$ & $0.6 / 0.4$ & $0.4 / 0.4$ & $0.4 / 0.4$ & $0.4 / 0.4$ & $0.4 / 0.4$ & $0.4 / 0.4$ & $0.4 / 0.6$
\end{tabular}

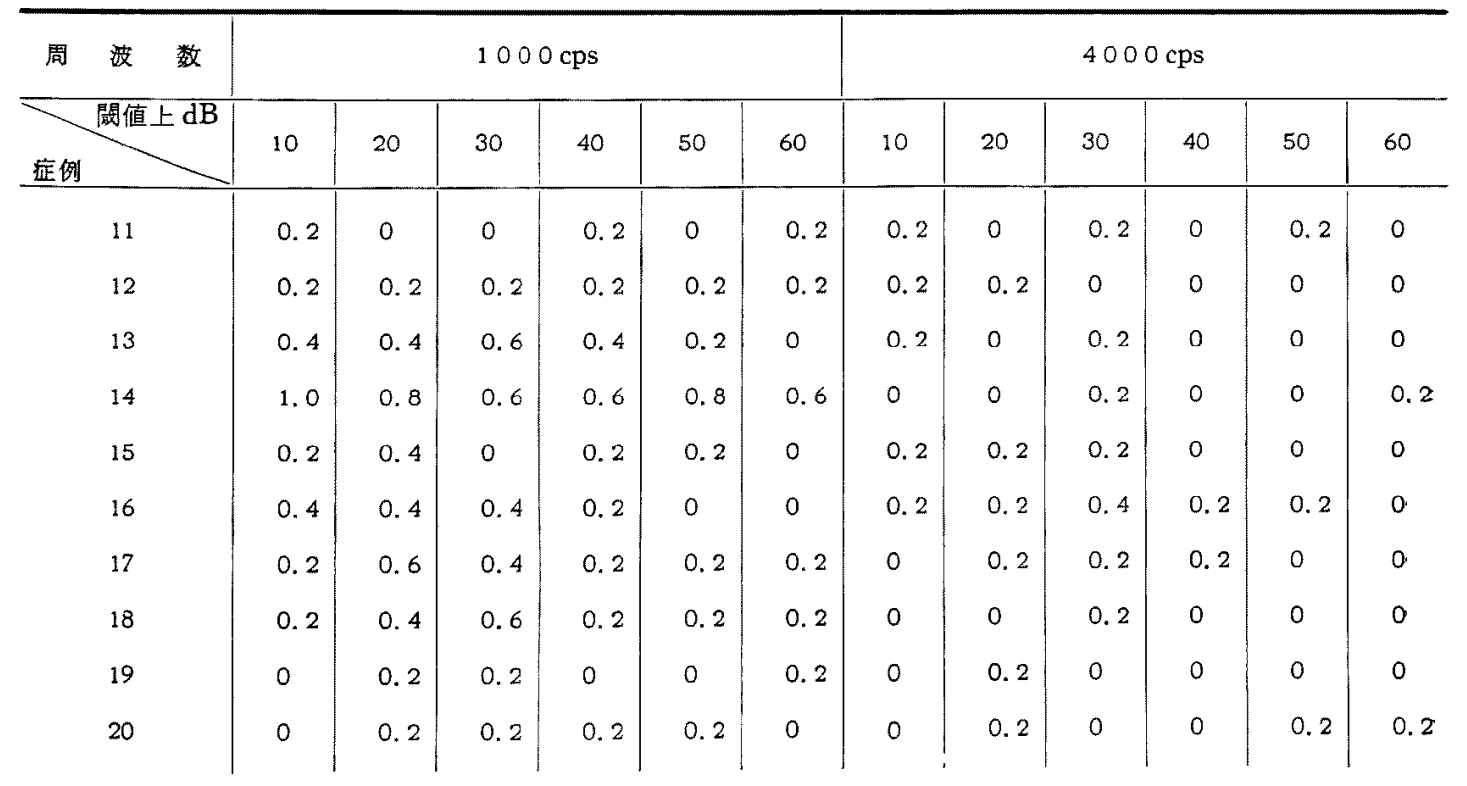




\begin{tabular}{|c|c|c|c|c|c|c|c|c|c|c|c|c|c|c|}
\hline \multirow{5}{*}{ 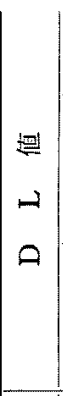 } & \multirow{3}{*}{$\rightarrow$} & & \multicolumn{3}{|c|}{ 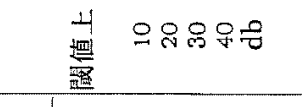 } & \multicolumn{3}{|r|}{ 으융용ㅇㅁㅁㅁ } & \multicolumn{3}{|c|}{ 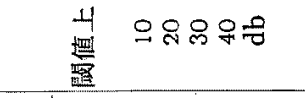 } & \multicolumn{2}{|c|}{ 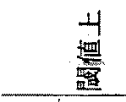 } & 으유욨와웅 \\
\hline & & $\frac{y}{\sigma}$ & & & & $\stackrel{q}{q}$ & & $\begin{array}{l}\infty \\
\dot{-} \\
\dot{2}\end{array}$ & 占 & & \begin{tabular}{l}
$0 \infty \infty \infty$ \\
\hdashline 000 \\
-000 \\
\end{tabular} & 윰 & & 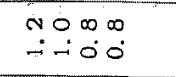 \\
\hline & & 些 & & & & 品 & & $\stackrel{\infty}{-} \stackrel{+}{-} \stackrel{\sim}{-}$ & $\stackrel{p g}{7}$ & & $\begin{array}{l}\because 0 \infty \infty \\
\therefore-00 \\
\therefore\end{array}$ & 品 & & $\begin{aligned}-\pi \\
\therefore\end{aligned}$ \\
\hline & \multirow{2}{*}{$\sim$} & $\frac{y}{7}$ & 邑 & & \begin{tabular}{l}
$N O \infty$ \\
\hdashline-100 \\
-100 \\
\end{tabular} & & & & & & & 우 & & 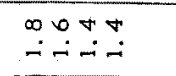 \\
\hline & & $\cong$ & ㅇ & & $\stackrel{0}{0} \because ّ$ & & & & & & & $\mathscr{8}$ & & \begin{tabular}{l}
$\circ$ \\
\hdashline$\sim 口$
\end{tabular} \\
\hline \multirow{7}{*}{\multicolumn{2}{|c|}{ 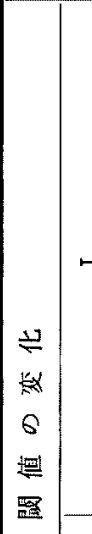 }} & $\underset{\infty}{\infty}$ & & & & $\mathscr{q}$ & 0 & 음요요 & $\stackrel{9}{7}$ & $\circ$ & 윽목몽요 & 足 & 0 & 으모욤용 \\
\hline & & $\underset{0}{0}$ & & & & 里 & $n$ & レ음ำ뭉 & $\stackrel{n}{+}$ & 23 & 几上号邑 & 웅 & $i$ & ๒上윰유 \\
\hline & & 冚 & & & & 8 & $\circ$ & 임욤몽 & 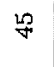 & 0 & 으느노ำ & 우 & $i$ & 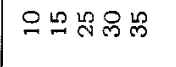 \\
\hline & & 㤐 & & & & 욱 & $n$ & 용 品品 & 윰 & 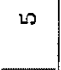 & 어유용우 & 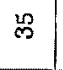 & $i$ & 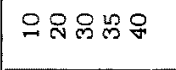 \\
\hline & & $\frac{x}{N}$ & & & & 孚 & $n$ & ம응ㅇㅇ & 题 & 20 & ๘ 넉 뭉 & 足 & $\circ$ & 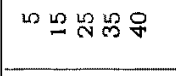 \\
\hline & & $\ddot{r}$ & & & & 吕 & $\infty$ & ம음묨요 & 品 & L & 으믕요요 & 邑 & 0 & 므요ㅇㅛㅛ \\
\hline & & 8 & & & & 오 & 20 & レッ 유 & 옥 & Ls & 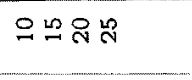 & 우 & 0 & மே유요 \\
\hline 0 & \multirow{7}{*}{24} & $\begin{array}{c}x \\
\infty\end{array}$ & 우 & $w$ & 으요요요 & & & & & & & 움 & $i$ & 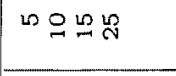 \\
\hline 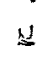 & & ֻै & g & 은 & 오용ㅇㅁ & & & & & & & ? & 0 & レッำ \\
\hline$\frac{\mathscr{n}}{3}$ & & $\frac{x}{y}$ & 足 & 20 & 늠 & & & & & & & $\stackrel{P}{T}$ & $i$ & น \\
\hline$\stackrel{巳}{\rightleftarrows}$ & & 总 & 8 & $\infty$ & 음융요아 & & & & & & & ㅇ & $i$ & 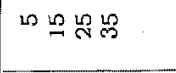 \\
\hline$B$ & & N & 우 & 으 & 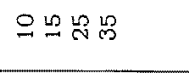 & & & & & & & $\mathscr{p}$ & $\stackrel{9}{1}$ & 음 웡 \\
\hline & & $\underline{-}$ & 유 & $\cong$ & 응요 옹 & & & & & & & 8 & $\stackrel{9}{1}$ & 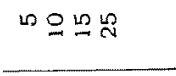 \\
\hline & & $\stackrel{8}{8}$ & $\stackrel{\square}{\square}$ & 욤 & 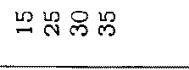 & & & & & & & 品 & $\stackrel{2}{i}$ & 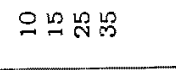 \\
\hline & \multirow[t]{2}{*}{ 룔 } & \multirow{2}{*}{$\begin{array}{l}\text { 乘 } \\
\text { 树 } \\
\text { 距 } \\
\end{array}$} & 操 & 敏 & \multirow{2}{*}{ 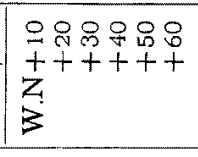 } & 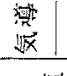 & 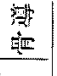 & \multirow{2}{*}{ 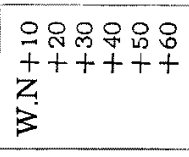 } & 海 & 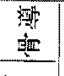 & \multirow{2}{*}{ 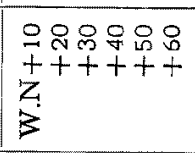 } & $\begin{array}{l}\text { 漂 } \\
\sqrt{x}\end{array}$ & $\begin{array}{l}\text { 冴 } \\
\text { 策 }\end{array}$ & \multirow{2}{*}{ 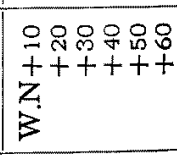 } \\
\hline & & & 场 & & & 揌 & & & 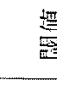 & & & 场 & & \\
\hline \multicolumn{3}{|c|}{ 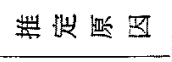 } & \multicolumn{3}{|c|}{ 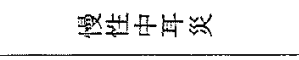 } & \multicolumn{3}{|c|}{ 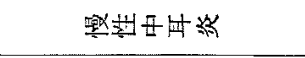 } & \multicolumn{3}{|c|}{ 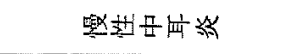 } & \multicolumn{3}{|c|}{ 荋划巨地些 } \\
\hline \multicolumn{3}{|c|}{ 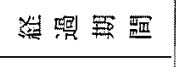 } & \multicolumn{3}{|c|}{ 雚 } & \multicolumn{3}{|r|}{ 过 } & \multicolumn{3}{|c|}{ 芒 } & & & 范 \\
\hline 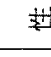 & & $\sqrt{2}$ & & & 䟥 & & & $\not x$ & & & 炽 & & & $\not x$ \\
\hline 4 & & $4 F$ & & & 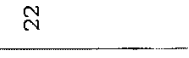 & & & 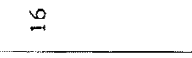 & & & $\stackrel{\infty}{-}$ & & & $\stackrel{2}{-}$ \\
\hline & 㤩 & & & & $\ddot{\Sigma}$ & & & $\begin{array}{l}\Sigma \\
\dot{\mu}\end{array}$ & & & $\underset{\sum}{\sum}$ & & & $\begin{array}{l}n \\
\Sigma\end{array}$ \\
\hline & 京的 & & & & - & & & $\kappa$ & & & $\infty$ & & & + \\
\hline
\end{tabular}




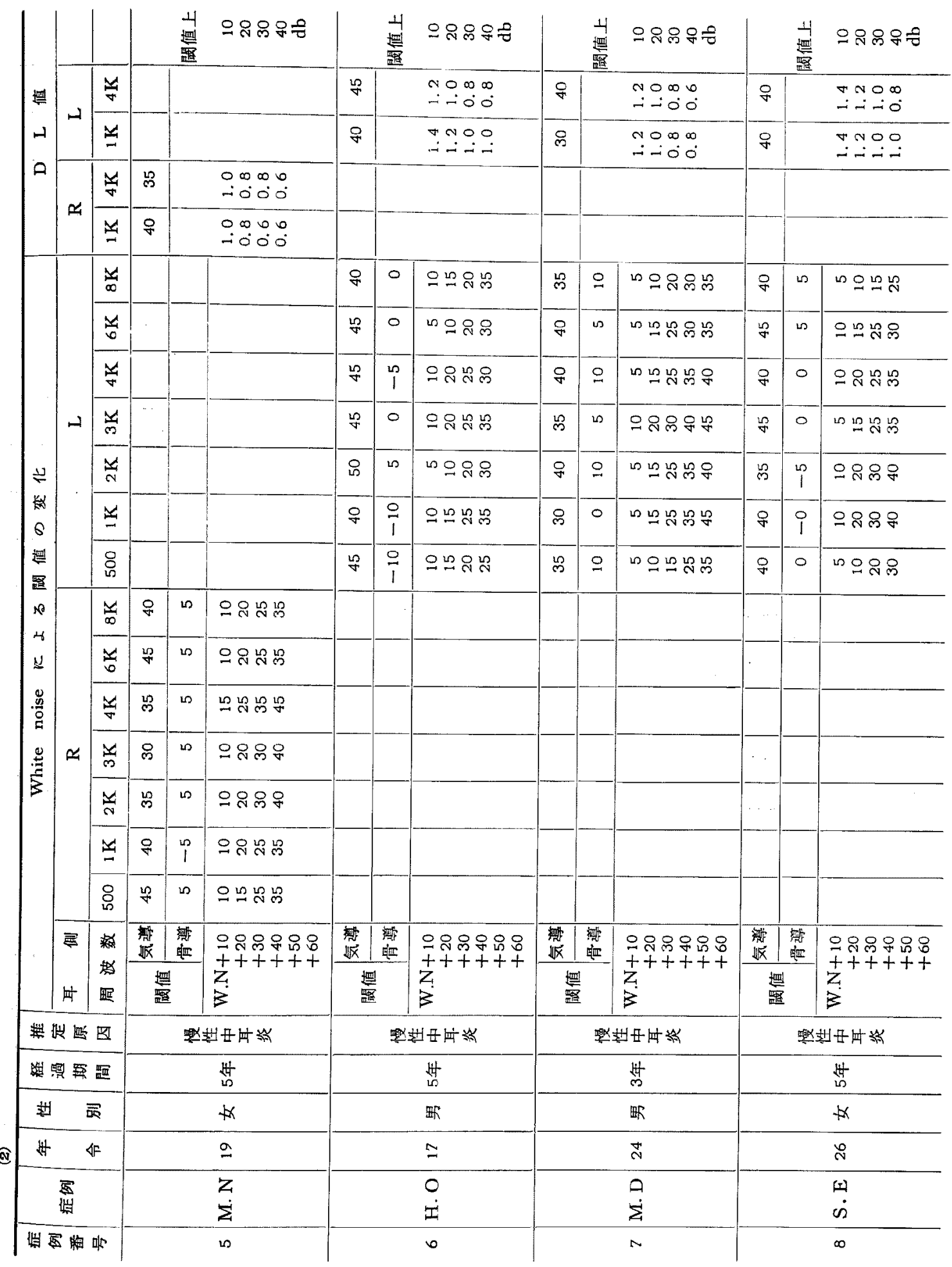




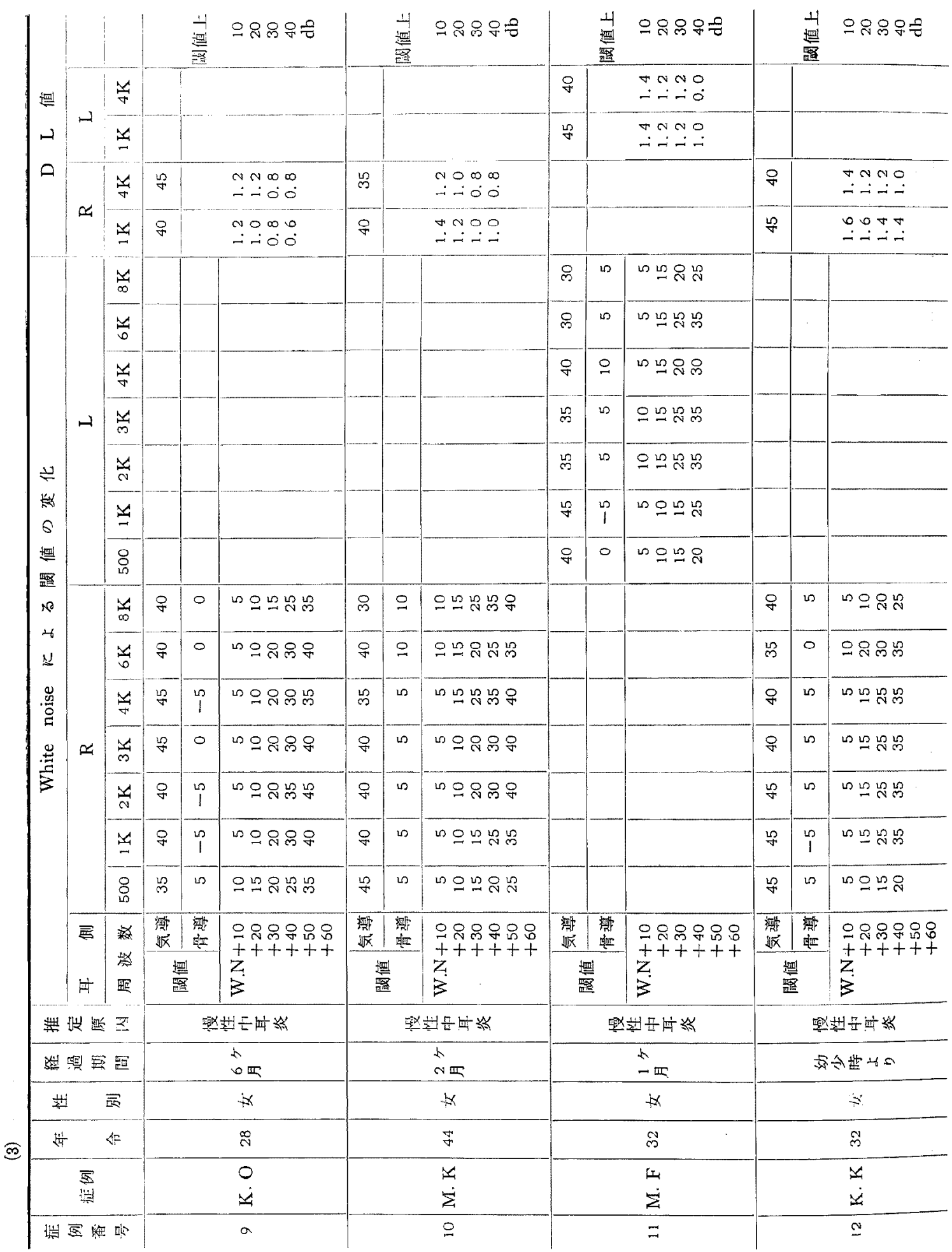




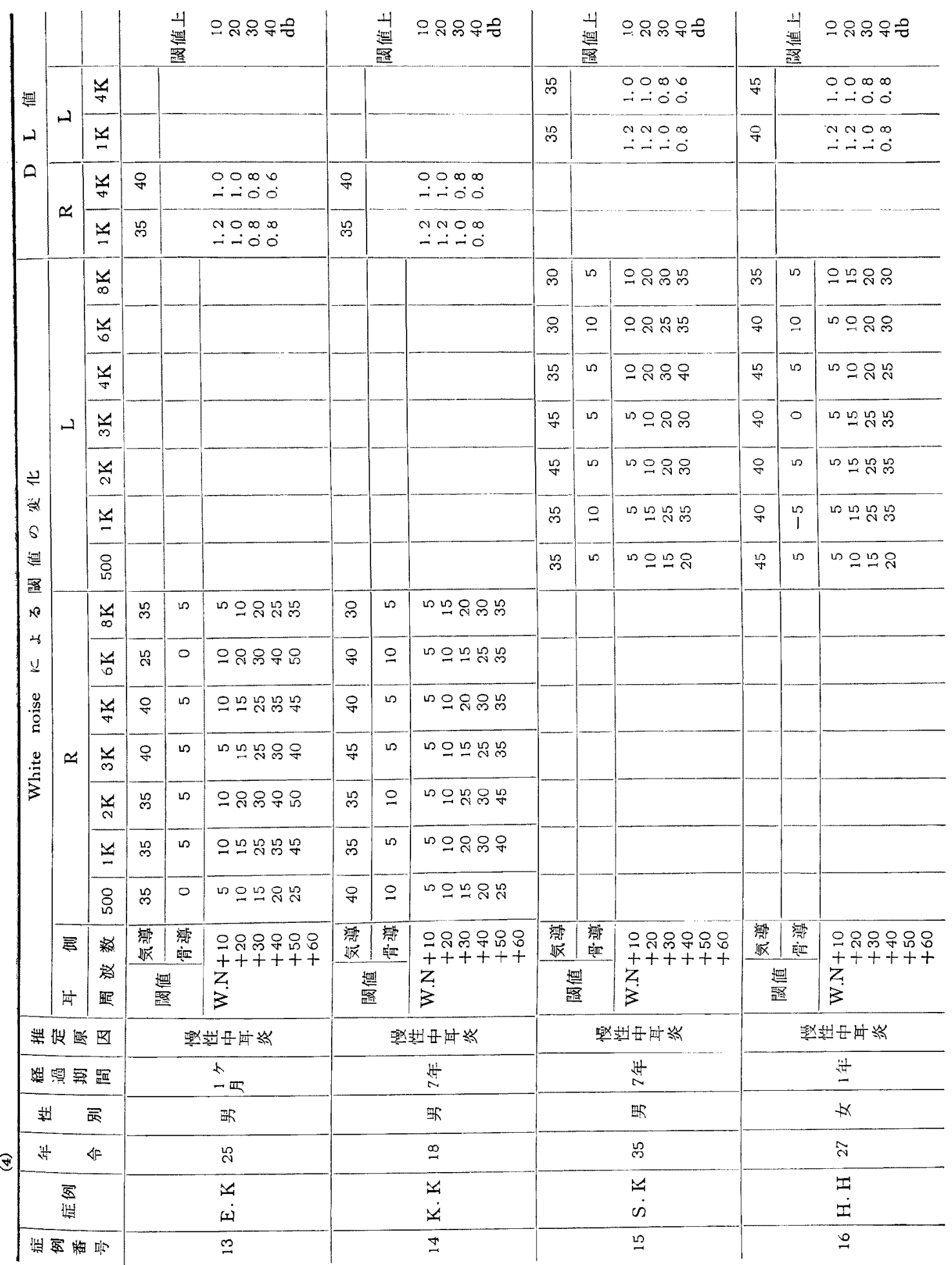




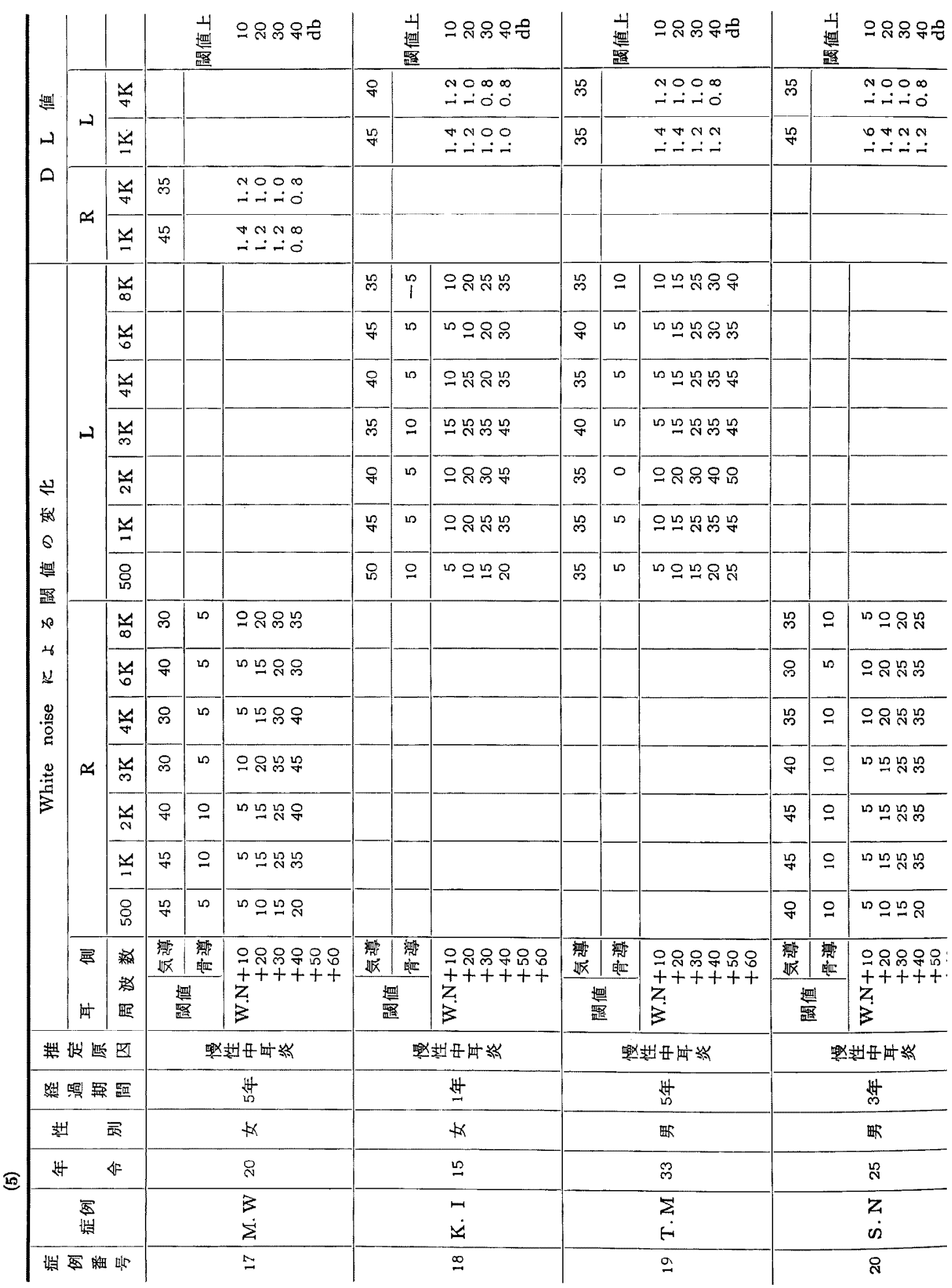




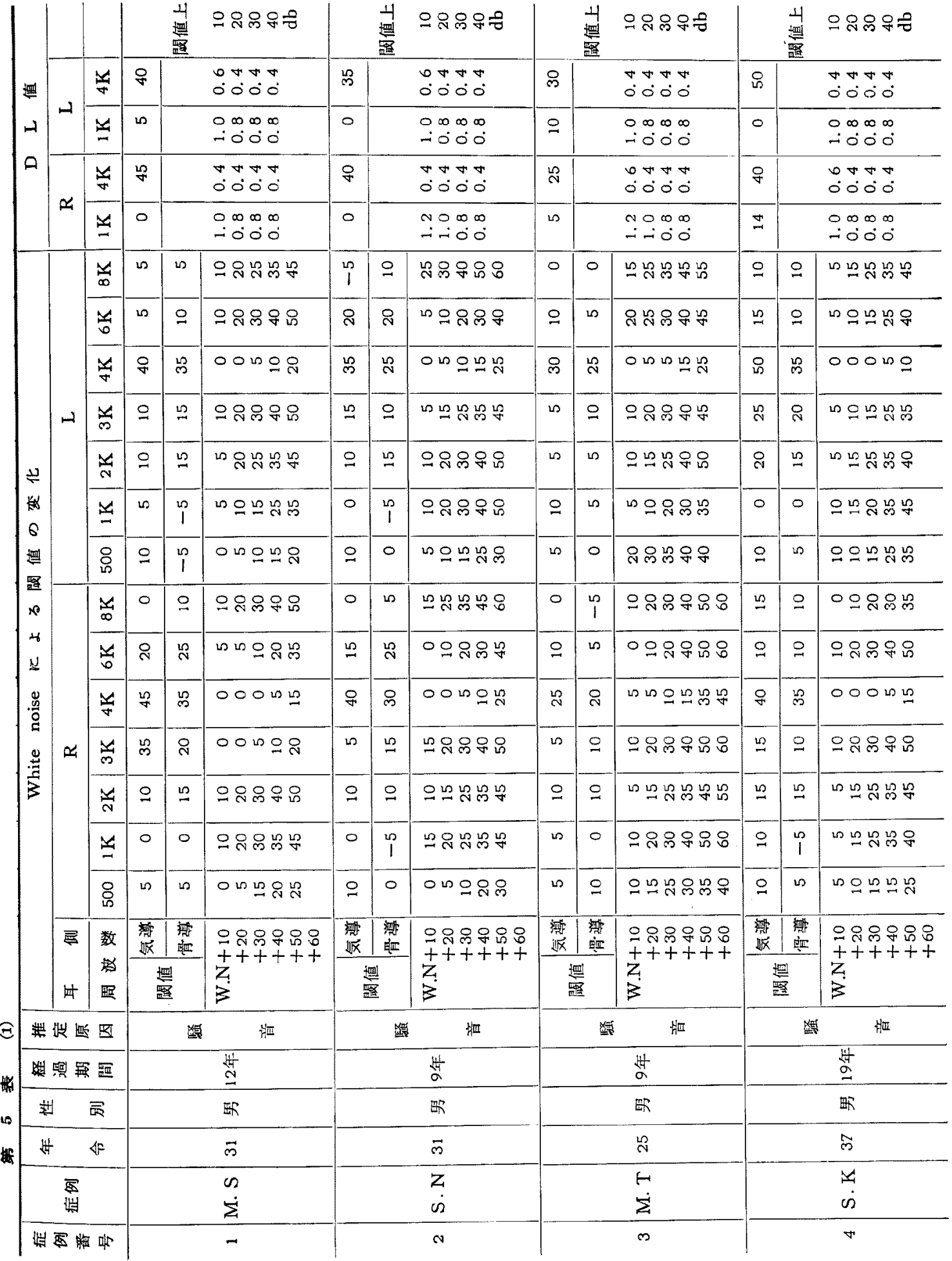




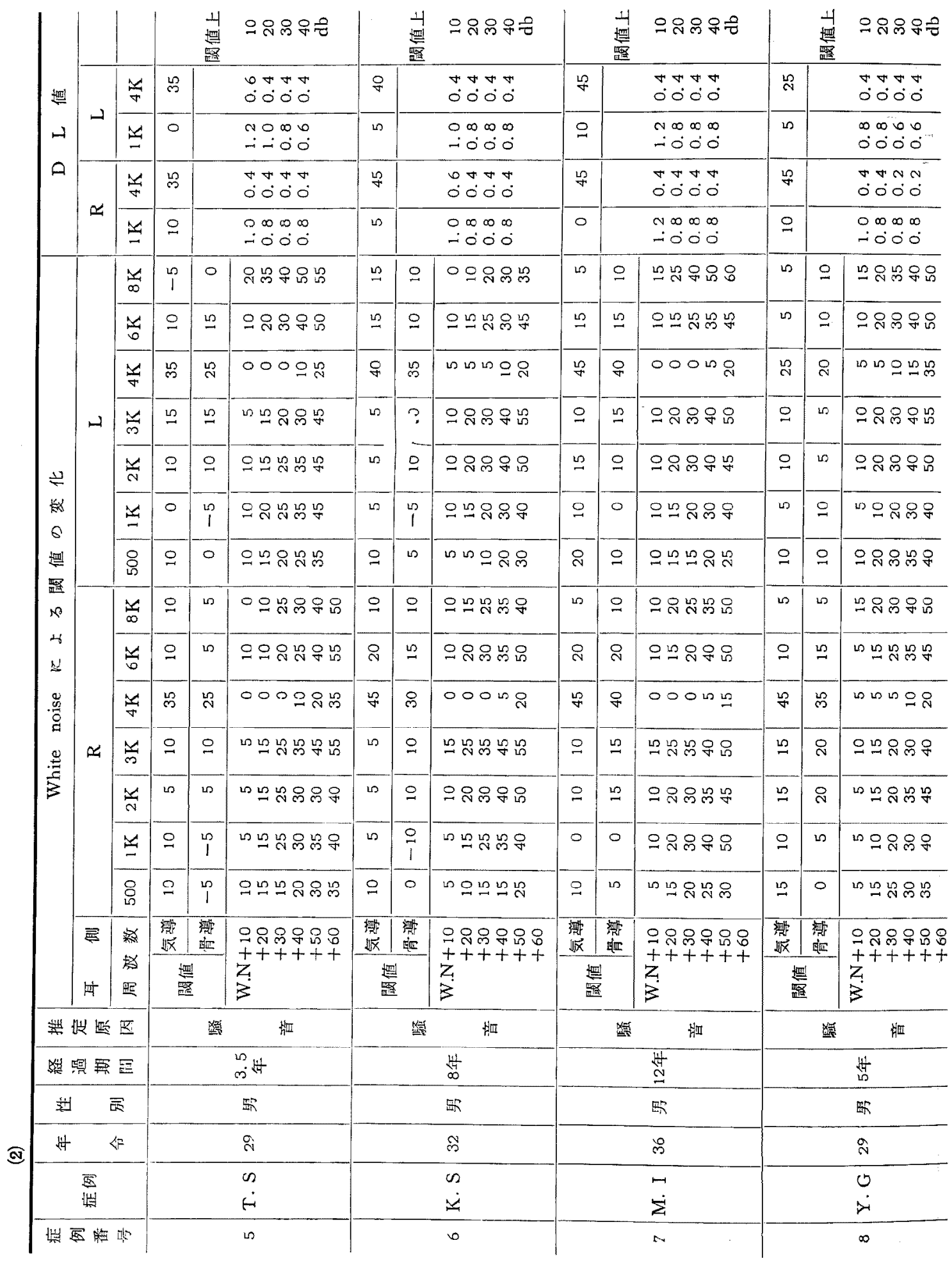




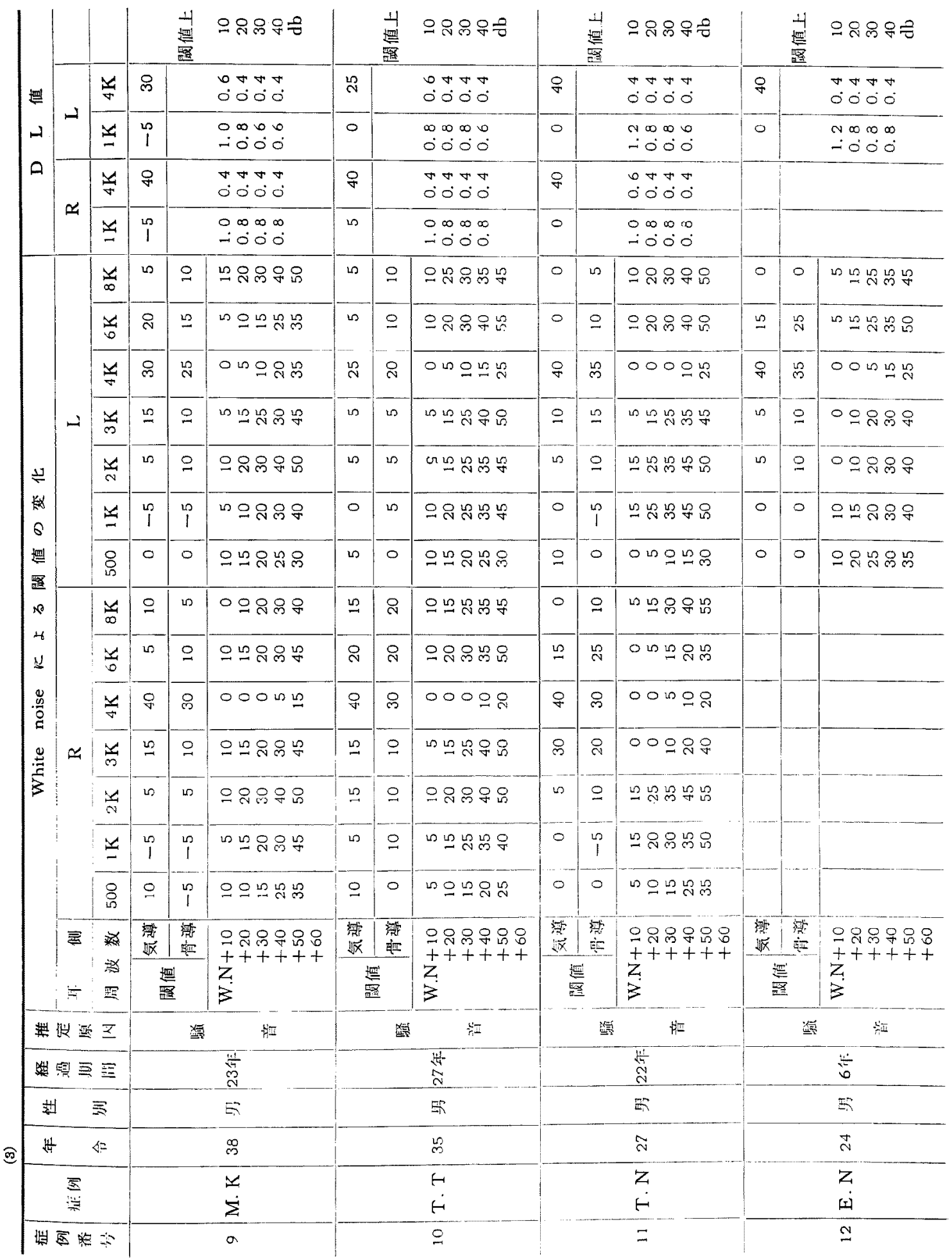




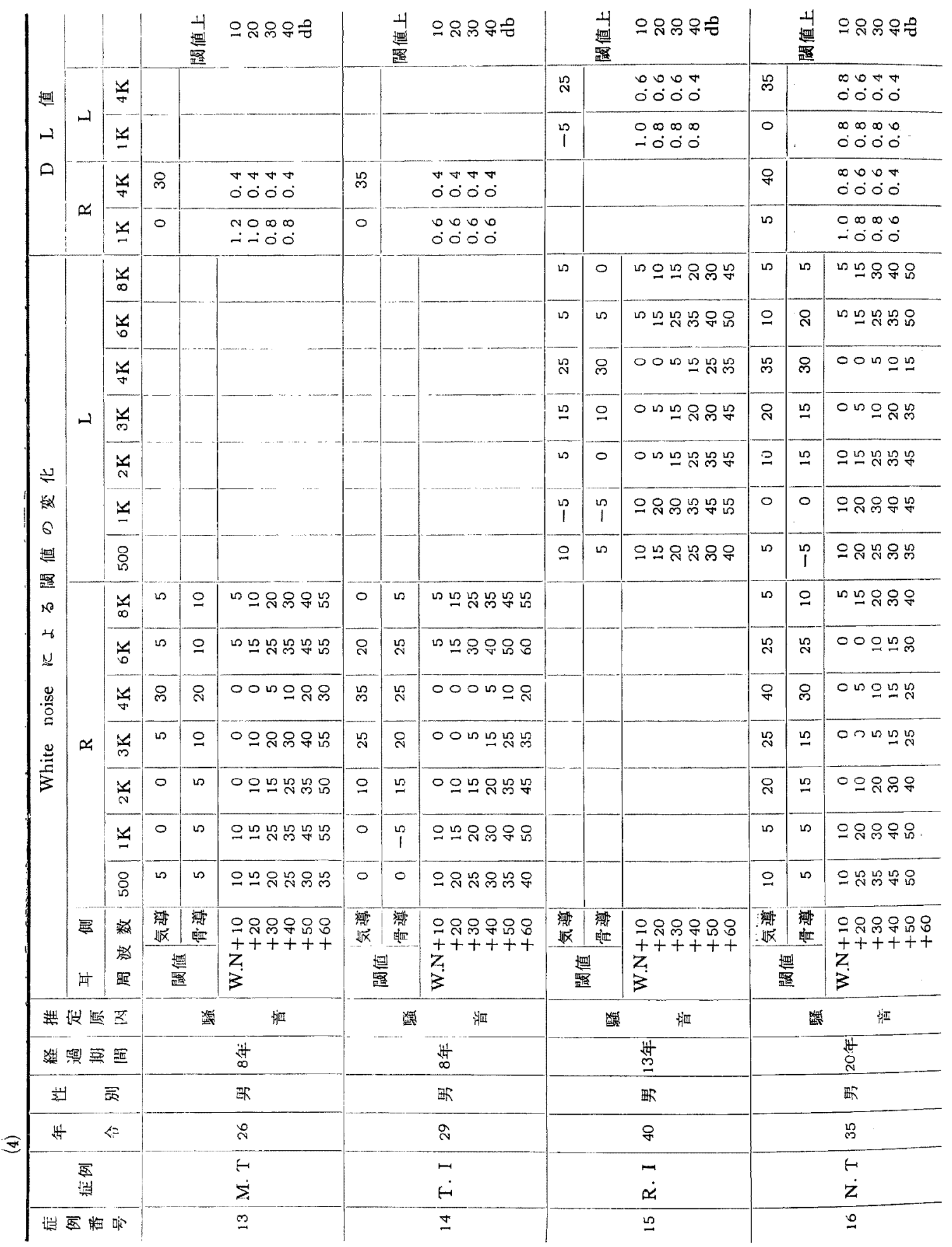




\begin{tabular}{|c|c|c|c|c|c|c|c|c|}
\hline & & & & 岑恶 & 응유욤 & & 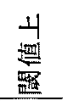 & 음ㅇㅁㅇㅁ욤 \\
\hline \multirow{4}{*}{$\begin{array}{l}\text { 型 } \\
-1 \\
-1\end{array}$} & & $\frac{4}{4}$ & $\mathscr{7}$ & & \begin{tabular}{l}
0000 \\
\hdashline 00 \\
-0.00
\end{tabular} & $\mathscr{q}$ & & 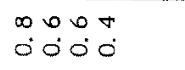 \\
\hline & & $\underline{4}$ & $ㅇ$ & & $\begin{array}{l}0 \infty \infty 0 \\
-0000\end{array}$ & 웅 & & $\begin{array}{l}0 \infty \infty \infty \\
\because 000 \\
\therefore 0\end{array}$ \\
\hline & \multirow{2}{*}{$\approx$} & 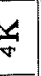 & 品 & & $\begin{array}{l}\infty 000 \\
000 \\
00\end{array}$ & ำ & & $\begin{array}{l}000 \pi \\
-00 \\
-0\end{array}$ \\
\hline & & 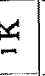 & 尺े & & 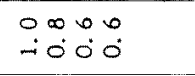 & n & & 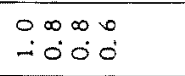 \\
\hline \multirow{7}{*}{\multicolumn{2}{|c|}{ 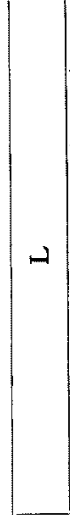 }} & 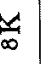 & ิㅗ & 요 & 능ㅇㅇㅇㅇㅇㅇㅛ & 오 & 요 & ๘응유욤뉴 \\
\hline & & 范 & $\stackrel{20}{=}$ & 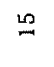 & 으용요 桌 & 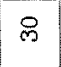 & 8 & แ음유 \\
\hline & & 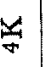 & $\stackrel{p}{*}$ & 욱 & 00000 & $\stackrel{2}{\square}$ & 号 & $000 \mathrm{n}$ \\
\hline & & m & 8ิ & $\circ$ & 으유욤우 & $\stackrel{4}{a}$ & 요 & 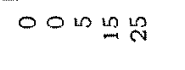 \\
\hline & & $\frac{1}{N}$ & 요 & $\stackrel{2}{-1}$ & 응요욨 & $\stackrel{2}{2}$ & 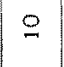 & 으유몽요 \\
\hline & & $\because$ & 으 & 0 & 응요웅ㅁㅁ & 잉 & 0 & 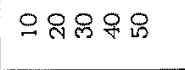 \\
\hline & & 8 & $\infty$ & $i$ & 오능요용ㅇ & 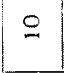 & 0 & 음요앵우 \\
\hline \multirow{7}{*}{\multicolumn{2}{|c|}{$\mathscr{x}$}} & 商 & ஜ & 尺े & 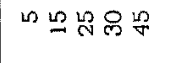 & 용 & $\stackrel{\sim}{N}$ & ๒ \\
\hline s. & & كَّ & 움 & ஓ & 느유욤워 & $\stackrel{\sim}{\sim}$ & $\stackrel{\mathrm{N}}{2}$ & 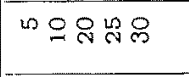 \\
\hline$\stackrel{\mathscr{m}}{\stackrel{m}{a}}$ & & $\frac{y}{y}$ & 品 & के & 00000 & 온 & 文 & 00001 \\
\hline & & 幽 & 욤 & q & 00010 & 욱 & 욤 & 0009 요 \\
\hline 3 & & $\stackrel{x}{N}$ & 유 & $\stackrel{p}{\rho}$ & ○เน็น & 品 & 8 & ం బ \\
\hline & & $\because$ & 요 & $\mathscr{-}$ & 응요욤움 & เ & 0 & 으믐용우 웅 \\
\hline & & 号 & $ㅇ$ & $p$ & 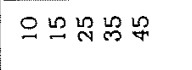 & wo & 0 & 으늠ㅁㅁㅅㅁㅇㅛ \\
\hline \multirow{2}{*}{\multicolumn{2}{|c|}{ 룔 }} & 洣 & $\begin{array}{l}\text { 整 } \\
\text { 忟 } \\
\end{array}$ & 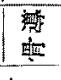 & \multirow{2}{*}{$\mid \begin{array}{l}0.909080 \\
++++++ \\
z \\
3\end{array}$} & $\begin{array}{l}\text { 旅 } \\
\sqrt[4]{x}\end{array}$ & 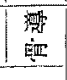 & \multirow{2}{*}{ 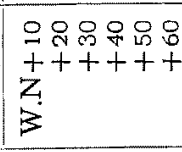 } \\
\hline 虫 & & 期 & 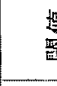 & 罡 & & 㖶 & & \\
\hline \multicolumn{3}{|c|}{ 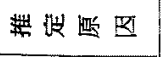 } & \multicolumn{3}{|c|}{ 牙 } & \multicolumn{3}{|c|}{ 露 } \\
\hline \multicolumn{3}{|c|}{ 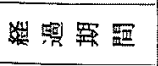 } & \multicolumn{3}{|r|}{$\frac{4}{2}$} & \multicolumn{3}{|r|}{$\underset{\mathrm{d}}{\mathrm{du}}$} \\
\hline \multicolumn{3}{|l|}{$\uplus$} & \multicolumn{3}{|r|}{ 酸 } & \multicolumn{3}{|r|}{ 㧽 } \\
\hline \multicolumn{3}{|c|}{ स $\quad \&$} & \multicolumn{3}{|r|}{$q$} & \multicolumn{3}{|r|}{ if } \\
\hline \multicolumn{3}{|c|}{ 蛋 } & \multicolumn{3}{|r|}{$\ddot{H}$} & \multicolumn{3}{|r|}{$\begin{array}{l}\Psi \\
\dot{m}\end{array}$} \\
\hline \multicolumn{3}{|c|}{ 齿相 } & \multicolumn{3}{|r|}{ 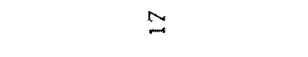 } & \multicolumn{3}{|r|}{$\stackrel{\infty}{-}$} \\
\hline
\end{tabular}




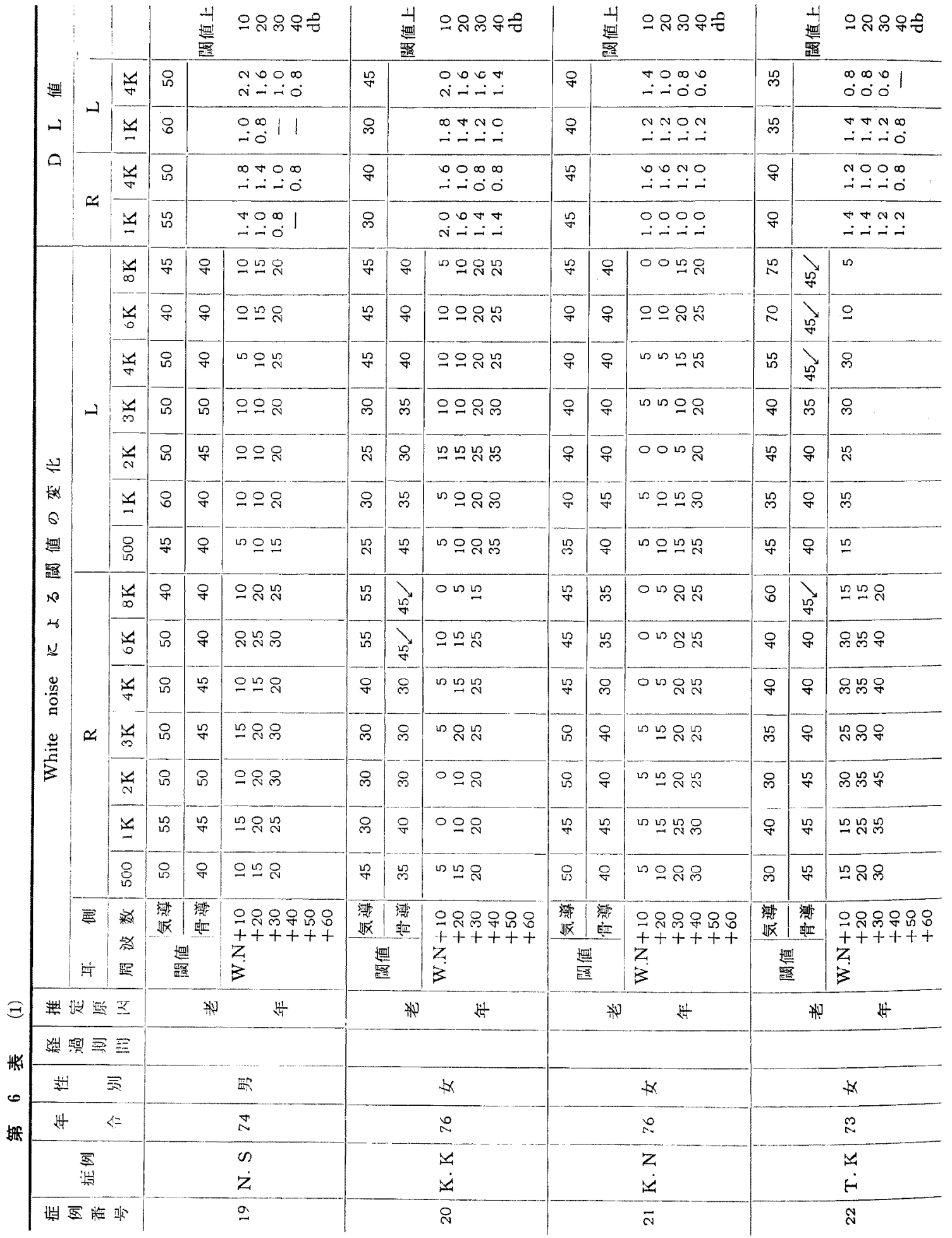




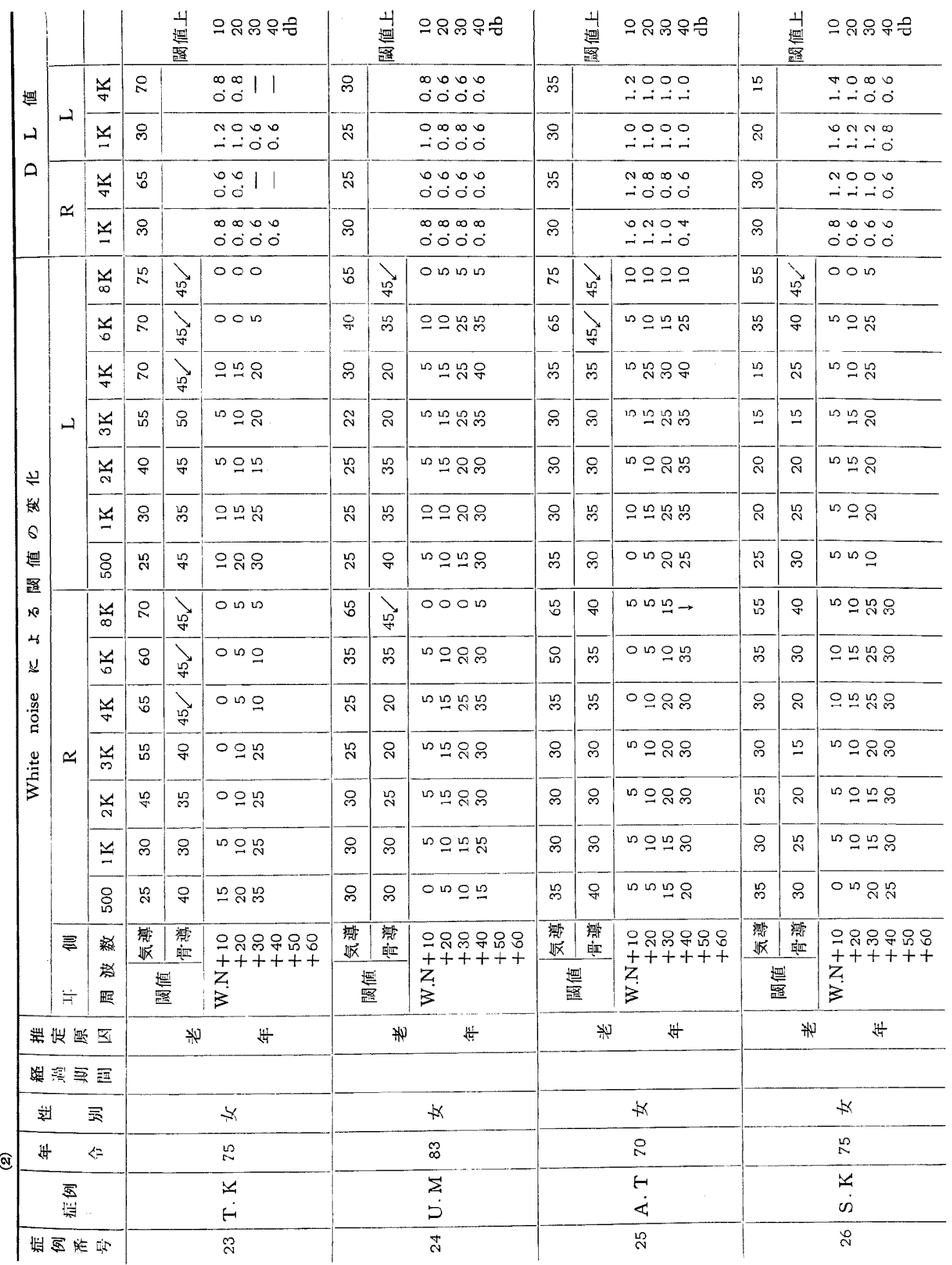




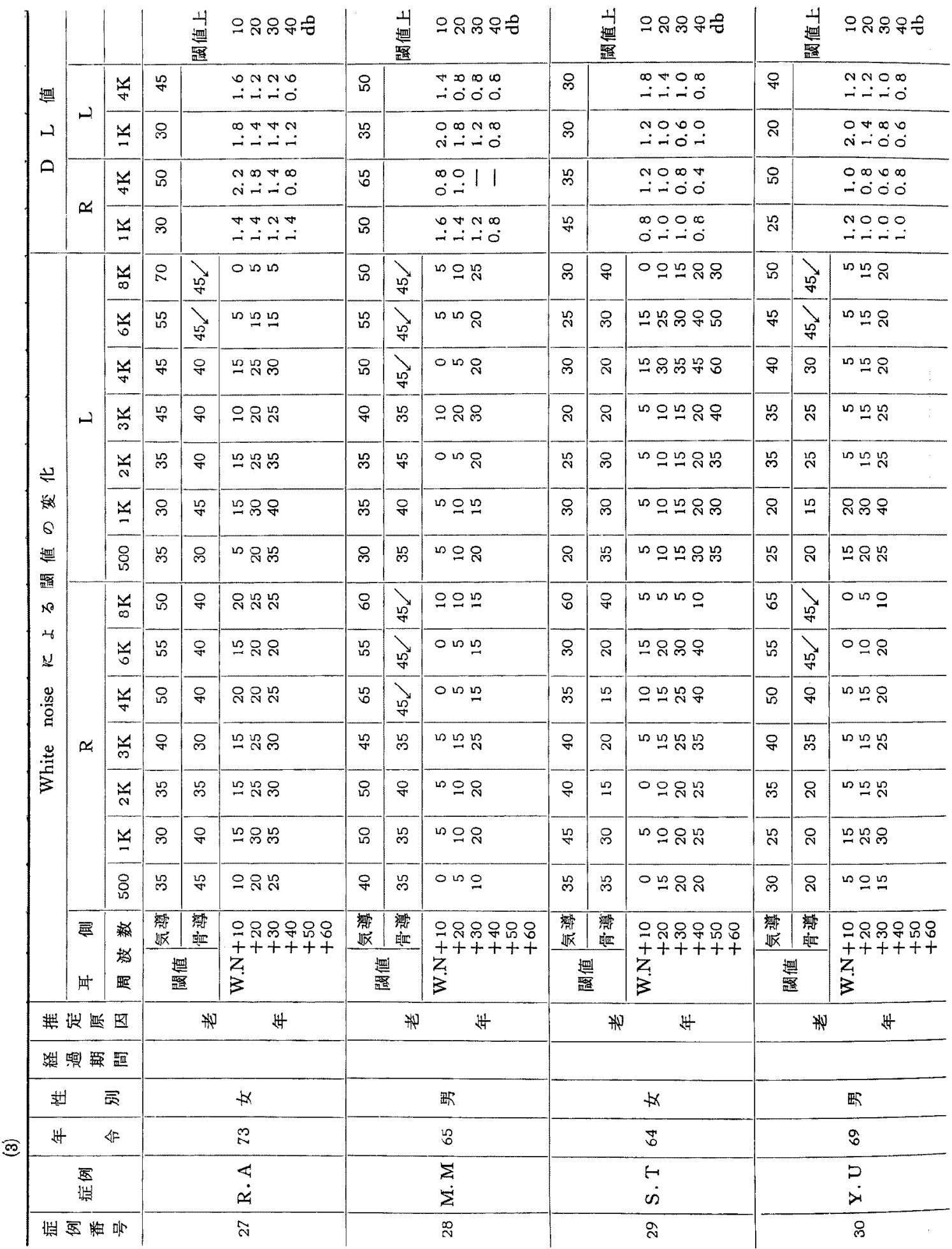




\begin{tabular}{|c|c|c|c|c|c|c|c|c|}
\hline \multirow{5}{*}{$\begin{array}{l}\text { 遇 } \\
-\end{array}$} & \multirow{3}{*}{$\omega$} & & \multicolumn{2}{|r|}{ 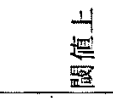 } & 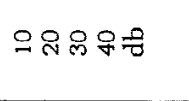 & \multicolumn{2}{|r|}{$\begin{array}{l}4 \\
\text { 尰 } \\
\text { 题 }\end{array}$} & 융ㅇㅁㅇㅠ \\
\hline & & 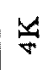 & 号 & & 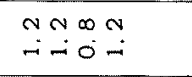 & 워 & & 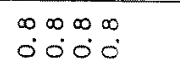 \\
\hline & & $\underline{-~}$ & 品 & & 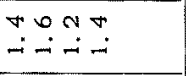 & 品 & & $\begin{array}{l}\infty 0 \infty 0 \\
0.0 \\
0.0\end{array}$ \\
\hline & & $\frac{x}{\sigma}$ & 옴 & & $\begin{array}{l}00 \infty \\
-1-00 \\
-10\end{array}$ & $\mathscr{7}$ & & $\begin{array}{l}0000 \\
-000 \\
-00\end{array}$ \\
\hline & & 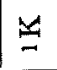 & 邑 & & $\begin{array}{l}000 \\
-100 \\
-100 \\
\end{array}$ & ஓ & & 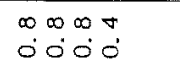 \\
\hline \multirow{16}{*}{ 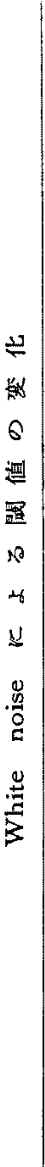 } & \multirow{7}{*}{ H } & $\frac{4}{\infty}$ & 옹 & के & n $n \subseteq \underset{\sim}{\circ}$ & 8 & \& & $n \circ \stackrel{x}{\sim}$ \\
\hline & & $\frac{1}{0}$ & 吕 & 안 & ๓요묘 & 옹 & 8 & 으묘용 \\
\hline & & $\stackrel{4}{\sigma}$ & $\stackrel{m}{\rho}$ & 户 & 음욕요요요 & 윰 & 우 & 응요 \\
\hline & & 㸚 & \& & ৪ & 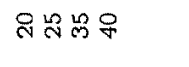 & ஜి & 8 & 으욤 \\
\hline & & 茨 & ஜ & 品 & 오늠용요 & p & 움 & 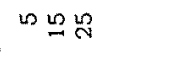 \\
\hline & & $\dddot{\varkappa}$ & 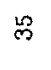 & $\stackrel{L}{\rho}$ & ㅇㅇㅇㅛ & ஜ & 只 & ๑뇸요 \\
\hline & & 8 & 号 & 邑 & 으요요 & ల్ల & 옴 & 응녹몽 \\
\hline & \multirow{7}{*}{$\approx$} & $\frac{4}{\infty}$ & 8 & g) & 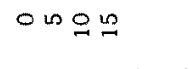 & 8 & 우 & ம유요 \\
\hline & & $\because 6$ & 욱 & 品 & 용ㅇ & 요 & 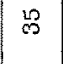 & $1 \bigsqcup$ \\
\hline & & $\frac{y}{7}$ & 응 & $\stackrel{\llcorner}{N}$ & 으음 & 孚 & ஜ & 늠요 \\
\hline & & 炎 & \& & g & 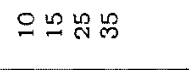 & 尺 & 요 & $\llcorner\stackrel{2}{\sim}$ \\
\hline & & 군 & हి & 户্ল & 으요요 & ల్ల & ৪ి & ら只号 \\
\hline & & $\because$ & $\stackrel{\leftrightarrow}{\infty}$ & 另 & ๓๐ & ले & தి & レ品号 \\
\hline & & 8 & $\stackrel{2}{q}$ & ஓ & 요음 & లి & ஜ & 으유요 \\
\hline & \multirow[t]{2}{*}{ 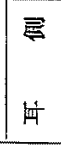 } & 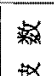 & 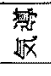 & 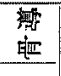 & \multirow{2}{*}{ 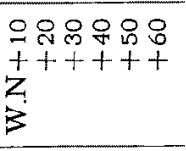 } & 整 & 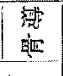 & \multirow{2}{*}{ 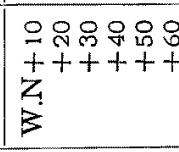 } \\
\hline & & 跟 & 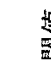 & & & $\begin{array}{l}\text { 浐 } \\
\text { 资 }\end{array}$ & 睘 & \\
\hline \multicolumn{3}{|c|}{ 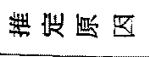 } & \multicolumn{3}{|c|}{ 利 } & \multicolumn{3}{|c|}{ 料 } \\
\hline \multicolumn{3}{|c|}{ 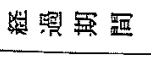 } & & & & & & \\
\hline \multicolumn{3}{|c|}{$\#$} & \multicolumn{3}{|r|}{$\not$} & \multicolumn{3}{|r|}{$x$} \\
\hline \multirow[t]{2}{*}{ 4 } & \multicolumn{2}{|c|}{ 价 } & \multicolumn{3}{|r|}{$\mathbb{N}$} & \multicolumn{3}{|r|}{2} \\
\hline & \multicolumn{2}{|c|}{ 霓 } & & & $\stackrel{H}{4}$ & & & $\dot{0}$ \\
\hline & ह & $\$$ & & & $\vec{m}$ & & & लै \\
\hline
\end{tabular}




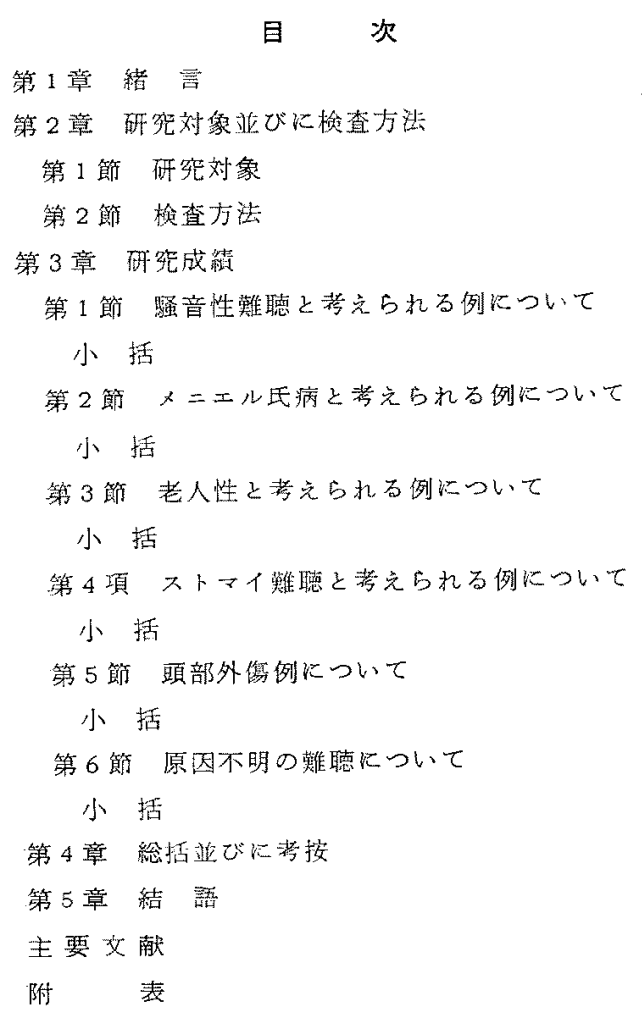

\section{第 1 章 緒言}

第1篇に扔ける研究結果を基にして，一般外来䠦床に おけ当感音難聴耳について，White noise 省用い，その

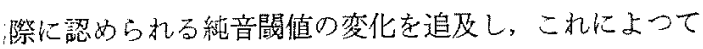
、臨床的な鑑別診断がどの程度可能であるかを明らかに L. 以つて本検查法の臨床的意義について検討せんとし to.

\section{第 2 章 研究対象並びに検査方法}

第 1 節 研究対象

研究対象注名古屋大学医学部附属病院耳鼻咽喉科外来 を訪れた難聴を訴える患者のらち。他覚的所見と既往榞 及び純音オージオメーターによる聴力検查で伀音采障恝 交否定し得たもの87名 151 耳の感音難㯖耳であり，その 年令, 性別, 経過期間, 推定原因及び純音䦪值は第 7 表 (1〜18) に示すよらでする。

第 2 節 検查方法

検查は名古屋大学医学部耳舆咽喉科学教室の防音検查 室で行つた。使用したオージオメーター㤝小林理研製の
$1013 \mathrm{~A}(1002 \mathrm{D})$ 型で, 検査方法は第 1 篇，第 2 章，第 2節に記したのと同じでるるので省略する。

\section{第3 章 研 究 成 緼}

外来臨床に捛ける感音難聴耳 151 耳について行つた White noise による純音閥値の変化上， $1 \mathrm{KC}, 4 \mathrm{KC}$ に捛 ける DL Test の成績は第 7 表 $(1 \sim 18)$ に示す通りで ある。

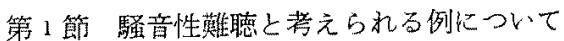

感音難㯖で，その原因が騒音性と考えられる19例35耳 について，純音閶值の上琴が特に著明な周波数及で閶值 が正常籁国内にあつて第 2 の型を示す周波数並びに $1 \mathrm{KC}, 4 \mathrm{KC}$ の閾值上 $20 \mathrm{~dB}$ と $30 \mathrm{~dB} に$ に扔る DL 值は次の よりである。

症例：1（R)

䦪值上昇が特に著明な $4 \mathrm{KC}, 6 \mathrm{KC}$ の noise audiogram は $4 \mathrm{KC}$ では閔值が $45 \mathrm{~dB}$ で（以下周波数の後の括弧内の 数字は閾值走示寸) 第 2 の型のB（以下 $2 \mathrm{~B}$ と記す）で あり，6KC (40dB) \& $2 \mathrm{~B}$ でるる。

閶值上 $20 \mathrm{~dB}, 30 \mathrm{~dB}$ に柇ける $1 \mathrm{KC}$ の DL 值は夫々0.8 $\mathrm{dB}, 0.8 \mathrm{~dB}$ で, $4 \mathrm{KC}$ では夫々0. $4 \mathrm{~dB}, 0.4 \mathrm{~dB}$ である.

$4 \mathrm{KC}$ の noise audiogram は第 2 の型で DL 值は小で ある。

症例： 1（L)

閾值上昇が特に藷明な $4 \mathrm{KC}(50 \mathrm{~dB}), 6 \mathrm{KC}(40 \mathrm{~dB})$ ， $8 \mathrm{KC}(45 \mathrm{~dB})$ の noise audiogram 梳々 $2 \mathrm{C}, 2 \mathrm{E}$, 2 Bでする。

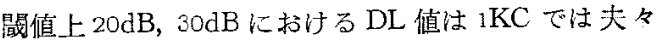
$0.6 \mathrm{~dB}, 1.0 \mathrm{~dB}$ で, $4 \mathrm{KC}$ では夫々0. $4 \mathrm{~dB}, 0.4 \mathrm{~dB}$ である. $4 \mathrm{KC}$ の noise audiogram は第 2 の型で DL 值は小た ある。

症例 : $2(\mathrm{R})$

閶值上昇が特に著明な $6 \mathrm{KC}(30 \mathrm{~dB})$ の noise audiogdam は2 Bであり，4KC (10dB) では第1の型であ \%.

閶值上 $20 \mathrm{~dB}, 30 \mathrm{~dB}$ に扔ける DL 值は $1 \mathrm{KC}$ で注夫 $0.6 \mathrm{~dB}, 0.6 \mathrm{~dB}$ で, $4 \mathrm{KC}$ では夫々 $0.8 \mathrm{~dB}, 0.6 \mathrm{~dB}$ である. $4 \mathrm{KC}$ の noise audiogram は第 1 の型で DL 值は中等 值である。

湑例 : 2 (L)

閧值上昇が特に著明な $4 \mathrm{KC}(30 \mathrm{~dB})$ の noise audio- 
gram は2 Bである.

閶值上 $20 \mathrm{~dB}, 30 \mathrm{~dB}$ における $\mathrm{DL}$ 值は $1 \mathrm{KC}$ では夫.ヶ $0.6 \mathrm{~dB}, 0.6 \mathrm{~dB}$ で， $4 \mathrm{KC}$ では夫々 $0.8 \mathrm{~dB}, 0.6 \mathrm{~dB}$ である. . $4 \mathrm{KC} の$ noise audiogram は第 2 の型で DL 值は中等 值である。

症例：3（R)

閏值上昇が特に著明な $2 \mathrm{KC}(55 \mathrm{~dB}) ， 3 \mathrm{KC}(55 \mathrm{~dB})$, $4 \mathrm{KC}(55 \mathrm{~dB}), 6 \mathrm{KC}(45 \mathrm{~dB})$ の noise audiogram 柱夫々 $2 \mathrm{C}, 2 \mathrm{C}, 2 \mathrm{~B}, 2 \mathrm{E}$ である.

闘值上 $20 \mathrm{~dB}, 30 \mathrm{~dB}$ における $\mathrm{DL}$ 值は $1 \mathrm{KC}$ では夫ヶ $0.4 \mathrm{~dB}, 0.4 \mathrm{~dB}$ で, $4 \mathrm{KC}$ では夫々 $0.4 \mathrm{~dB}, 0.4 \mathrm{~dB}$ である. $4 \mathrm{KC}$ の noise audiogram 注第 2 の型で $\mathrm{DL}$ 值は小で ある.

症例：3(L)

閶值上昇が特に著明な $4 \mathrm{KC}(35 \mathrm{~dB}), 6 \mathrm{KC}(30 \mathrm{~dB}) の$ noise audiogram は夫々 $2 \mathrm{E}, 2 \mathrm{~B}$ である.

閔值上 $20 \mathrm{~dB}, 30 \mathrm{~dB}$ における DL 值恃 $1 \mathrm{KC}$ では夫々 $1.0 \mathrm{~dB}, 0.6 \mathrm{~dB}$ で， $4 \mathrm{KC}$ で壮夫々0. $4 \mathrm{~dB}, 0.4 \mathrm{~dB}$ である。

$4 \mathrm{KC}$ の noise audiogram は第 2 の型で DL 值は小で ある.

症例：4（R)

閔值上昇が特に著明な $3 \mathrm{KC}(50 \mathrm{~dB}) ， 4 \mathrm{KC}(55 \mathrm{~dB}) の$ noise audiogram 注何れも 2 Cである。

2KC (5dB) の noise audiogram は2 Bである.

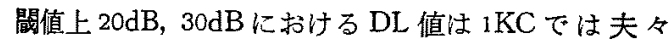
1. $4 \mathrm{~dB}, 1.2 \mathrm{~dB}$ で, $4 \mathrm{KC}$ では夫々0. $4 \mathrm{~dB}, 0.4 \mathrm{~dB}$ である. $4 \mathrm{KC} の$ noise audiogram 注第 2 の型で DL 值は小で ある。

症例：4（L)

閔值上昇が特に著明な $3 \mathrm{KC}(40 \mathrm{~dB}), 4 \mathrm{KC}(45 \mathrm{~dB})$, $6 \mathrm{KC}(40 \mathrm{~dB}), 8 \mathrm{KC}(40 \mathrm{~dB}) の$ noise audiogram は夫 々2 B, 2 B第 1 の型， 2 Eである.

閶值上 $20 \mathrm{~dB} ， 30 \mathrm{~dB}$ における $\mathrm{DL}$ 值は $1 \mathrm{KC}$ な゙ま 1. $0 \mathrm{~dB}, 0.8 \mathrm{~dB}$ で， $4 \mathrm{KC}$ では夫々0. $4 \mathrm{~dB}, 0.4 \mathrm{~dB}$ である. $4 \mathrm{KC}$ の noise audiogram 注第 2 の型で DL 值は小で むる.

定例： 5 (R)

閶值上昇が特に著明な $3 \mathrm{KC}(50 \mathrm{~dB}), 4 \mathrm{KC}(50 \mathrm{~dB})$ の noise audiogram は何れも2 Bである.

閶值上 $20 \mathrm{~dB}, 30 \mathrm{~dB}$ 亿扔ける DL 值注 $1 \mathrm{KC}$ ではま $1.4 \mathrm{~dB}, 1.0 \mathrm{~dB}$ で， $4 \mathrm{KC}$ では夫々0. $4 \mathrm{~dB}, 0.4 \mathrm{~dB}$ である. $4 \mathrm{KC}$ の noise audiogram は第 2 の型で DL 值隹小で ある。
症例： 5 (L)

闒值上昇が特に著明な $2 \mathrm{KC}(55 \mathrm{~dB}) ， 3 \mathrm{KC}(55 \mathrm{~dB})$ ， $4 \mathrm{KC}(50 \mathrm{~dB}), 6 \mathrm{KC}(45 \mathrm{~dB}) \oslash$ noise audiogram 快 々 $2 \mathrm{C}, 2 \mathrm{C}, 2 \mathrm{E}, 2 \mathrm{~A}+2 \mathrm{E}$ である。

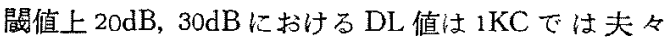
$1.0 \mathrm{~dB}, 0.8 \mathrm{~dB}$ で， $4 \mathrm{KC}$ では夫々 $0.4 \mathrm{~dB}, 0.4 \mathrm{~dB}$ である. $4 \mathrm{KC} の$ noise audiogam は第 2 型で DL 值は小で ある。

\section{症例：6（R)}

閔值上昇が特に著明な $3 \mathrm{KC}(55 \mathrm{~dB}) ， 4 \mathrm{KC}(60 \mathrm{~dB})$, $6 \mathrm{KC}(55 \mathrm{~dB}), 8 \mathrm{KC}(55 \mathrm{~dB}) \emptyset$ noise audiogram 仗夫 2 $\mathrm{E}, 2 \mathrm{E}, 2 \mathrm{~B}, 2 \mathrm{E}$ であ。

闇值上 $20 \mathrm{~dB}, 30 \mathrm{~dB}$ に㧍ける $\mathrm{DL}$ 值は $1 \mathrm{KC}$ では夫ヶ $0.6 \mathrm{~dB}, 0.6 \mathrm{~dB}$ で， $4 \mathrm{KC}$ では夫々 $0.4 \mathrm{~dB}, 0.4 \mathrm{~dB}$ である. $4 \mathrm{KC}$ の noise audiogram は第2 の型で DL 值は小で ある。

\section{症例：6（L)}

閾值上㫧が特に著明な $3 \mathrm{KC}(60 \mathrm{~dB}) ， 4 \mathrm{KC}(70 \mathrm{~dB})$, ${ }_{6} \mathrm{KC}(60 \mathrm{~dB})$ の noise audiogram は夫々 $2 \mathrm{C}, 2 \mathrm{D}$, 2 Cである。

閔值上 $20 \mathrm{~dB} ， 30 \mathrm{~dB}$ に扔ける DL 值は $1 \mathrm{KC}$ では夫 $0.6 \mathrm{~dB}, 0.8 \mathrm{~dB}$ で, $4 \mathrm{KC}(70 \mathrm{~dB})$ では閔值上 $30 \mathrm{~dB}$ では 検查不能で，關值上 $20 \mathrm{~dB}$ で $0.4 \mathrm{~dB}$ である。

$4 \mathrm{KC} の$ noise audiogram は第 2 の型で DL 值は小で ある。

症例：7（R)

閥值上昇が特に著明な $6 \mathrm{KC}(55 \mathrm{~dB})$ の noise audiogramは2 Dであり，4KC (20dB) では第1 の型である.

闒值上 $20 \mathrm{~dB}, 30 \mathrm{~dB}$ に抢ける $\mathrm{DL}$ 值は $1 \mathrm{KC}$ で注夫々 $0.6 \mathrm{~dB}, 0.6 \mathrm{~dB}$ で, $4 \mathrm{KC}$ では夫ヶ $0.6 \mathrm{~dB}, 0.4 \mathrm{~dB}$ である. $4 \mathrm{KC} の$ noise audiogram 㤌第 1 の型で DL 值は中等 值である。

\section{症例：7(L)}

䦪值上界が特に著明な $3 \mathrm{KC}(40 \mathrm{~dB}), 4 \mathrm{KC}(50 \mathrm{~dB})$, $6 \mathrm{KC}(50 \mathrm{~dB}), 8 \mathrm{KC}(45 \mathrm{~dB})$ の noise audiogram は夫 々, $2 \mathrm{~A}, 2 \mathrm{~B}, 2 \mathrm{E}, 2 \mathrm{E}$ である。

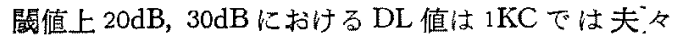
$0.6 \mathrm{~dB}, 0.6 \mathrm{~dB}$ で， $4 \mathrm{KC}$ では夫ね0. $4 \mathrm{~dB}, 0.4 \mathrm{~dB}$ である. $4 \mathrm{KC}$ の noise audiogram は第 2 の型で $\mathrm{DL}$ 值は小で ある。

\section{症例 : $8(\mathrm{R})$}

閶值上昇が特に著明な $3 \mathrm{KC}(45 \mathrm{~dB}), 4 \mathrm{KC}(50 \mathrm{~dB})$ の noise audigram は夫々 $2 \mathrm{E}, 2 \mathrm{C}$ であ。. 


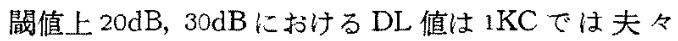
$0.8 \mathrm{~dB}, 0.6 \mathrm{~dB}$ で， $4 \mathrm{KC}$ では夫ぬ0. $4 \mathrm{~dB}, 0.4 \mathrm{~dB}$ である. $4 \mathrm{KC}$ の noise audiogram 站 2 の型で DL 值訬小で ある。

\section{症例：8（L)}

闒值上昇が特に著明な $2 \mathrm{KC}(50 \mathrm{~dB}), 3 \mathrm{KC}(55 \mathrm{~dB})$, $4 \mathrm{KC}(50 \mathrm{~dB})$ の noise audiogram は夫ヶ $2 \mathrm{E}, 2 \mathrm{D}$,

2 Eである:

闐上 $20 \mathrm{~dB}, 30 \mathrm{~dB}$ にお汀る DL 值は $1 \mathrm{KC}$ では夫タ $0.6 \mathrm{~dB}, 0.6 \mathrm{~dB}$ で， $4 \mathrm{KC}$ では夫々 $0.4 \mathrm{~dB}, 0.4 \mathrm{~dB}$ である.

$4 \mathrm{KC} の$ noise audiogram は第 2 の型で DL 值は小で ある.

症例：9(R)

間值上萃が特に著明な $8 \mathrm{KC}(50 \mathrm{~dB})$ の noise audio-

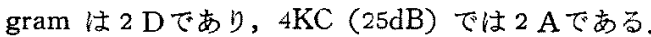

閶值上 $20 \mathrm{~dB}, 30 \mathrm{~dB}$ 亿㧍ける $\mathrm{DL}$ 值は $1 \mathrm{KC}$ では夫ヶ $0.6 \mathrm{~dB}, 0.6 \mathrm{~dB}$ で， $4 \mathrm{KC}$ では夫々 $0.4 \mathrm{~dB}, 0.4 \mathrm{~dB}$ である.

$4 \mathrm{KC} の$ noise audiogram は第 2 の型で DL 值は小で ある。

症例 : $10(\mathrm{R})$

闒值上界が特に著明な $6 \mathrm{KC}(55 \mathrm{~dB})$ ，8KC (60dB) の

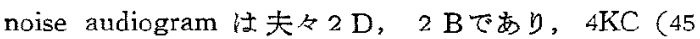
dB) では 2 Cである。

閔值上 $20 \mathrm{~dB}, 30 \mathrm{~dB}$ における $\mathrm{DL}$ 值は $1 \mathrm{KC}$ でまタ $1.2 \mathrm{~dB}, 1.0 \mathrm{~dB}$ で， $4 \mathrm{KC}$ では夫々 $0.4 \mathrm{~dB}, 0.4 \mathrm{~dB}$ である.

$4 \mathrm{KC}$ の noise audiogram 注第 2 の型で DL 值は小で ある。

症例：10（L)

䦪值上昇が特に著明な $8 \mathrm{KC}(60 \mathrm{~dB})$ の) noise audio-

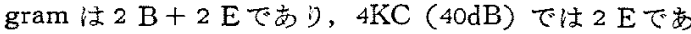
る.

閔值上 $20 \mathrm{~dB}, 30 \mathrm{~dB}$ に㧈ける DL 值仗 $1 \mathrm{KC}$ では夫タ 1. $0 \mathrm{~dB}, 0.8 \mathrm{~dB}$ で， $4 \mathrm{KC}$ では夫々0. $4 \mathrm{~dB}, 0.4 \mathrm{~dB}$ である. $4 \mathrm{KC}$ の noise audiogram 注第 2 の型で DL 值注小て ある。

\section{症例：11（R)}

闇値上界が特に著明な $4 \mathrm{KC}$ ( $45 \mathrm{~dB}$ ) の noise audiogram は 2 Bである。

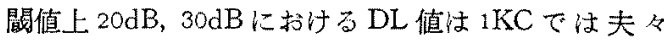
0. $8 \mathrm{~dB}, 0.8 \mathrm{~dB}$ で， $4 \mathrm{KC}$ では夫々 $0.4 \mathrm{~dB}, 0.4 \mathrm{~dB}$ である. $4 \mathrm{KC} の$ noise audiogram 注第 2 の型で DL 值は小で ある。

症例 : 11（L)
閥值上界が特に著明な $4 \mathrm{KC}(45 \mathrm{~dB}) ， 6 \mathrm{KC}(35 \mathrm{~dB})$ の noise audiogram は夫々 $2 \mathrm{~A}+2 \mathrm{E}, 2 \mathrm{~A}$ である。

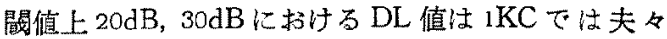
$0.6 \mathrm{~dB}, 0.6 \mathrm{~dB}$ で， $4 \mathrm{KC}$ では夫々 $0.4 \mathrm{~dB}, 0.4 \mathrm{~dB}$ である. $4 \mathrm{KC} の$ noise audiogram は第 2 の型で DL 値は小で ある。

症例 : $12(\mathrm{R})$

閶值上昇が特に著明な $6 \mathrm{KC}(40 \mathrm{~dB}) ， 8 \mathrm{KC}(35 \mathrm{~dB})$ の noise audiogram は何れも $2 \mathrm{~B}$ であり，4KC $(20 \mathrm{~dB})$ では，第 1 の型である。

闒值上 $20 \mathrm{~dB}, 30 \mathrm{~dB}$ に扔ける DL 值仗 $1 \mathrm{KC}$ では夫タ $0.8 \mathrm{~dB}, 1.0 \mathrm{~dB}$ で, $4 \mathrm{KC}$ では夫々 $0.6 \mathrm{~dB}, 0.6 \mathrm{~dB}$ である. $4 \mathrm{KC} の$ noise audiogram は第 1 の型で DL 值住中等 値である。

症例：13（R)

閾值上昇が特に著明な $6 \mathrm{KC}(50 \mathrm{~dB}) ８ \mathrm{KC}(50 \mathrm{~dB})$ の noise audiogram は夫々 $2 \mathrm{~B}, 2 \mathrm{D}$ であり，4KC (35 dB)では 2 Bである。

閥值上 $20 \mathrm{~dB}, 30 \mathrm{~dB}$ 亿扔ける DL 值は $1 \mathrm{KC}$ では夫々 $1.6 \mathrm{~dB}, 1.4 \mathrm{~dB}$ で， $4 \mathrm{KC}$ では夫々0. $4 \mathrm{~dB} ， 0.4 \mathrm{~dB}$ である. $4 \mathrm{KC} の$ noise audiogram 任第 2 の型で DL 值は小で ある。

症例：13(L)

閔值上昇が特に著明な $3 \mathrm{KC}(25 \mathrm{~dB}) ， 4 \mathrm{KC}(35 \mathrm{~dB})$, $6 \mathrm{KC}(35 \mathrm{~dB}), 8 \mathrm{KC}(30 \mathrm{~dB})$ の noise audiogram は夫 々 $2 \mathrm{E}, 2 \mathrm{~B}, 2 \mathrm{~A}, 2 \mathrm{E}$ である.

閩值上 $20 \mathrm{~dB}, 30 \mathrm{~dB}$ における $\mathrm{DL}$ 值は $1 \mathrm{KC}$ では夫タ $1.6 \mathrm{db}, 1.6 \mathrm{db}$ で， $4 \mathrm{KC}$ では夫々 $0.4 \mathrm{~dB}, 0.4 \mathrm{~dB}$ である. $4 \mathrm{KC} \sigma$ noise audiogram は第 2 の型で DL 值は小で ある。

症例 : $14(\mathrm{R})$

䦪值上昇が特に著明な $4 \mathrm{KC}$ (30dB) の noise audiogram は 2 Bである

闇值上 $20 \mathrm{~dB}, 30 \mathrm{~dB}$ に扔ける $\mathrm{DL}$ 值忙 $1 \mathrm{KC}$ では夫々 1.0dB，1.0dB で， $4 \mathrm{KC}$ では夫々0. $4 \mathrm{~dB}, 0.4 \mathrm{~dB}$ である. $4 \mathrm{KC}$ の noise audiogram 㳊第 2 の型で DL 值は小で ある。

\section{症例：14(L)}

關值上昇が特に著明な $4 \mathrm{KC}$ (30dB) の noise audiogram は 2 Bである。

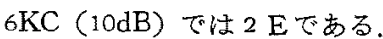

閖值上 $20 \mathrm{~dB}, 30 \mathrm{~dB}$ 亿招ける $\mathrm{DL}$ 值は $1 \mathrm{KC}$ では夫々 1. $2 \mathrm{~dB}, 1.0 \mathrm{~dB}$ で， $4 \mathrm{KC}$ では夫々 $0.4 \mathrm{~dB}, 0.4 \mathrm{~dB}$ である. 
4KCの noise audiogram 江第 2 の型で DL 值は小で 西る。

\section{症例：15（R)}

閖值上年が特に著明な $6 \mathrm{KC}(60 \mathrm{~dB})$ の noise audio-

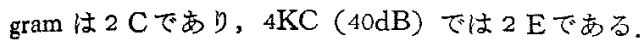

閶值上 $20 \mathrm{~dB}, 30 \mathrm{~dB}$ に扔ける DL 值は1 KC では夫タ 1. $2 \mathrm{~dB}, 1.0 \mathrm{~dB}$ で, $4 \mathrm{KC}$ では夫々 $0.4 \mathrm{~dB}, 0.4 \mathrm{~dB}$ である. $4 \mathrm{KC} の$ noise audiogram は第 2 の型で DL 值は小で ある.

症例 : $15(\mathrm{~L})$

閖值上昇が特に著明な $6 \mathrm{KC}(65 \mathrm{~dB})$ の noise audiogram は2 Cであり，4KC (45dB) では 2 Eである。

閣值上 $20 \mathrm{~dB}, 30 \mathrm{~dB}$ に扝ける DL 值は $1 \mathrm{KC}$ では夫々 $1.0 \mathrm{~dB}, 0.8 \mathrm{~dB}$ で， $4 \mathrm{KC}$ では夫く $0.4 \mathrm{~dB}, 0.4 \mathrm{~dB}$ である.

$4 \mathrm{KC} の$ noise audiogram は第 2 の型で DL 值は小で ある.

症例 $: 16(\mathrm{R})$

閶值上昇が特に著明な $6 \mathrm{KC}(40 \mathrm{~dB})$ の noise audiogram は $2 \mathrm{D}$ であり, $4 \mathrm{KC}(20 \mathrm{~dB})$ で注 $2 \mathrm{~A}+2 \mathrm{E}$ であ る.

闒値上 $20 \mathrm{~dB}, 30 \mathrm{~dB}$ に扔ける DL 值は $1 \mathrm{KC}$ では夫々 1.2dB，1.0dB で，4KC では夫々0.4dB，0.4dBである. $4 \mathrm{KC}$ の noise audiogram 第 2 の型で DL 值は小で 声る。

症例：16（L)

閖值上昇が特に著明な $4 \mathrm{KC}(50 \mathrm{~dB})$ の noise audiogram 注 $2 \mathrm{~B}+2$ Eである。

閔値上 $20 \mathrm{~dB}, 30 \mathrm{~dB}$ に扔ける DL 值は $1 \mathrm{KC}$ では夫タ 1. $4 \mathrm{~dB}, 1.2 \mathrm{~dB}$ で， $4 \mathrm{KC}$ では夫々 $1.0 \mathrm{~dB}, 0.8 \mathrm{~dB}$ である. $4 \mathrm{KC} の$ noise audiogram 注第 2 の型で DL 值住中等 犆である。

\section{症例 $: 17(\mathrm{R})$}

閩值上昇が特汇著明な $4 \mathrm{KC}$ ( $40 \mathrm{~dB}) の$ noise audiogram は 2 Bである。

閶值上 $20 \mathrm{~dB}, 30 \mathrm{~dB}$ に拈ける DL 值は $1 \mathrm{KC}$ では夫々 1. $4 \mathrm{~dB}, 1.2 \mathrm{~dB}$ で， $4 \mathrm{KC}$ で注夫々 $0.4 \mathrm{~dB}, 0.4 \mathrm{~dB}$ である. $4 \mathrm{KC}$ の nodise audiogram は第 2 の型で DL 值は小 である。

症例：17(L)

閖值上算が特に著明な $4 \mathrm{KC}(50 \mathrm{~dB})$ の noise audio-

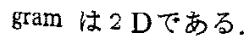

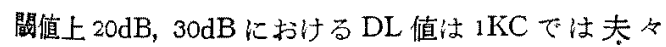
1.0dB, 1. OdB で， $4 \mathrm{KC}$ では夫々0. $4 \mathrm{~dB}, 0.4 \mathrm{~dB}$ である.
4KC の noise audiogram 注第 2 の型で DL 值は小で ある。

症例 : 18 ( L )

閔値上昇が特に著明な $4 \mathrm{KC}(35 \mathrm{~dB})$ の noise audiogram 注 2 Dである。

8KC (10dB) では2 Aである.

闇值上 $20 \mathrm{~dB}, 30 \mathrm{~dB}$ に打ける DL 值は $1 \mathrm{KC}$ では夫タ 1. $6 \mathrm{~dB} ， 1.2 \mathrm{~dB}$ で， $4 \mathrm{KC}$ では夫々0. $4 \mathrm{~dB}, 0.4 \mathrm{~dB}$ である.

$4 \mathrm{KC} の$ noise audiogram は第 2 の型で DL 值は小で ある。

症例 : $19(\mathrm{R})$

闒值上昇が特に著明な $8 \mathrm{KC}(85 \mathrm{~dB})$ の noise audiogram $2 \mathrm{C}$ であり，4KC (35dB) では 2 Eである。

闎值上 $20 \mathrm{~dB}, 30 \mathrm{~dB}$ に打引る DL 值は $1 \mathrm{KC}$ で夫ぬ $0.6 \mathrm{~dB}, 0.8 \mathrm{~dB}$ で, $4 \mathrm{KC}$ では夫々 $0.6 \mathrm{~dB}, 0.6 \mathrm{~dB}$ である.

$4 \mathrm{KC} の$ noise audiogram \&第 2 の型で DL 值怯中等 值である.

症例：19（L)

闒值上昇が特に著明な $8 \mathrm{KC}(80 \mathrm{~dB})$ の noise audiogram は2 Cであり，4KC（55dB）では2 Bである。

閶值上 $20 \mathrm{~dB}, 30 \mathrm{~dB}$ に扔ける DL 值は $1 \mathrm{KC}$ では夫タ $0.6 \mathrm{~dB}, 0.6 \mathrm{~dB}$ で，4KC では夫々 $0.8 \mathrm{~dB}, 0.6 \mathrm{~dB}$ である.

$4 \mathrm{KC} の$ noise audiogram 注第 2 の型で DL 值は中等 暄である。

\section{小括}

難聴の原因が騷音性と考えられる35耳の閵值上昇が特 に高度な周波数の noise audiogram は, 第 1 の型だけ 示するのはなく，第 2 の型を示するのが34耳であり，第 1 の型と第 2 の型が合併しているものが1耳である。

しかして4KCでは第1 の型を示寸ものが 3 耳 (2R， $7 \mathrm{R} ， 12 \mathrm{R})$ で，第 2 の型を示すものが32耳である.

次に $1 \mathrm{KC}, 4 \mathrm{KC}$ の閾值上 $20 \mathrm{~dB}$ と $30 \mathrm{~dB}$ 亿拈ける $\mathrm{DL}$ 值は次のようである。

$1 \mathrm{KC}$ で注閔值上 $20 \mathrm{~dB}, 30 \mathrm{~dB}$ のL值は夫々 $0.8 \mathrm{~dB}$, $0.6 \mathrm{~dB}$ から $1.6 \mathrm{~dB} ， 1.4 \mathrm{~dB}$ の閪にあり中等值の籁囲内に ある。

$4 \mathrm{KC}$ では闎值上 $20 \mathrm{~dB}, 30 \mathrm{~dB} の \mathrm{DL}$ 值は夫々0. $4 \mathrm{~dB}$ ， $0.4 \mathrm{~dB}$ から $1.0 \mathrm{~dB}, 0.8 \mathrm{~dB}$ の間にあり，小のものが多く， 中等值の範囲内にあるもの沙 7 耳に過ぎない，

しかして $4 \mathrm{KC}$ て第 2 の型を示す 32 耳でDL 值が小の ものは28耳である。第 2 の型を示し DL 值が中等値のも のは 4 耳である。

$4 \mathrm{KC}$ で第 1 の型在示す 3 耳の $\mathrm{DL}$ 值は中等值であり, 
純音閾值は $20 \mathrm{~dB}$ 又は $10 \mathrm{~dB}$ に過ぎない:

すなわち $\mathrm{DL}$ 值が中等值のものは 7 耳である。

$4 \mathrm{KC}$ で第 2 の型で DL 值が中等値の DL 值を仔細に 検討すると， 3 耳においては中等值の内では小さい部類 である。

次に純音閗値が正常籁国内にあつて，第 2 の型を示す あのは $4 \mathrm{R} の 2 \mathrm{KC}, 14 \mathrm{~L} の 6 \mathrm{KC}$ 及び18L の8KC である.

第 2 節 メニュル氏病と考えられる例について

感音難聴でその原因がメニエル氏病と考えられる7例 9 耳について純音閶值の上昇が特に著明な周波数及び闘 值が正常範围内にあつて noise audiogram が第 2 の型 を示す周波数，並びに $1 \mathrm{KC}, 4 \mathrm{KC}$ の闇值上 $20 \mathrm{~dB}$ と $30 \mathrm{~dB}$ におけるDL值は次のようである。

症例 : $20(\mathrm{R})$

閔值上昇が特に著明な $8 \mathrm{KC}(55 \mathrm{~dB})$ の noise audiogram 恃 2 Cであり，4KC (OdB) では第1の型である.

䦥值上 $20 \mathrm{~dB}, 30 \mathrm{~dB}$ に扔ける DL 值は1KCでは夫タ $1.0 \mathrm{~dB}, 1.0 \mathrm{~dB}$ で, $4 \mathrm{KC}$ では夫々 $1.2 \mathrm{~dB}, 0.8 \mathrm{~dB}$ である. $4 \mathrm{KC} の$ noise audiogram は第1の型で DL 值は中等 值である。

症例 : 21 (L)

間值上昇が特に著明な $6 \mathrm{KC}(30 \mathrm{~dB}), 8 \mathrm{KC}(35 \mathrm{~dB})$ の noise audiogram は夫々 $2 \mathrm{~A}, 2 \mathrm{~B} て ゙ あ り, 4 \mathrm{KC}$ (15 dB) では 2 Aである.

閔值上 $20 \mathrm{~dB}, 30 \mathrm{~dB}$ に括㚈西 $\mathrm{DL}$ 值は1 $\mathrm{KC}$ では夫々 1. $8 \mathrm{~dB}, 1.2 \mathrm{~dB}$ で, $4 \mathrm{KC}$ では夫々 $1.2 \mathrm{~dB}, 1.2 \mathrm{~dB}$ である. $4 \mathrm{KC} の$ noise audiogram は第 2 の型で DL 值は中等 值である。

症例: 22（R）

閔值上昇が特に著明な $8 \mathrm{KC}(45 \mathrm{~dB})$ の noise audiogram は $2 \mathrm{C}$ であり，4KC (5dB) で注第 1 の型である.

閥值上 $20 \mathrm{~dB}, 30 \mathrm{~dB}$ に㧍ける DL 值は $1 \mathrm{KC}$ では夫ヶ 1. $2 \mathrm{~dB}, 0.8 \mathrm{~dB}$ で， $4 \mathrm{KC}$ では夫々0. $6 \mathrm{~dB}, 0.4 \mathrm{~dB}$ である. $4 \mathrm{KC} の$ noise audiogram は第 1 型で DL 值は中等 值である。

症例 : $23(\mathrm{R})$

闒值上昇が特に著明な6 KC $(40 \mathrm{~dB}), 8 \mathrm{KC}(50 \mathrm{~dB})$ の noise audiogram は夫々 $2 \mathrm{E}, 2 \mathrm{E}$ であり, $4 \mathrm{KC}(20$ dB) では $2 \mathrm{~B}+2 \mathrm{E}$ である.

$2 \mathrm{KC}(5 \mathrm{~dB})$ では $2 \mathrm{~A}$ であり, $3 \mathrm{KC}(\mathrm{OdB})$ では $2 \mathrm{E}$ である。

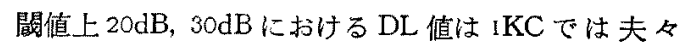
$0.6 \mathrm{~dB}, 0.6 \mathrm{~dB}$ で, $4 \mathrm{KC}$ では夫々 $0.2 \mathrm{~dB}, 0.4 \mathrm{~dB}$ である.
$4 \mathrm{KC} の$ noise audiogram は第 2 の型で DL 值は小で ある.

症例 : 23 (L)

闘值上昇が特に著明な $6 \mathrm{KC}(60 \mathrm{~dB}), 8 \mathrm{KC}(60 \mathrm{~dB})$ の noise audiogram は $6 \mathrm{KC}$ では White noisc $10 \mathrm{~dB}$ から

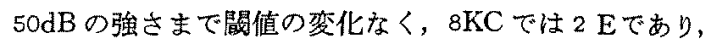

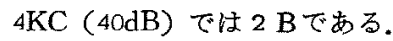

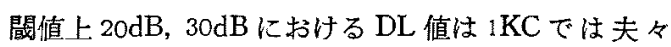

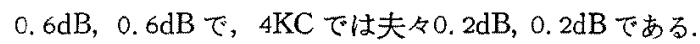

$4 \mathrm{KC} の$ noise audiogram 第 2 の型で DL 值は小で ある。

症例：24（R)

閾值上昇が特に著明な $8 \mathrm{KC}$ (60dB) の noise audiogram は $2 \mathrm{C}$ あ゙り, $4 \mathrm{KC}(45 \mathrm{~dB})$ では $2 \mathrm{~A}$ である.

闒值上 $20 \mathrm{~dB}, 30 \mathrm{~dB}$ における $\mathrm{DL}$ 值は $1 \mathrm{KC}$ では夫ヶ 0. $6 \mathrm{~dB}, 0.6 \mathrm{~dB}$ で， $4 \mathrm{KC}$ では夫々0. $4 \mathrm{~dB}, 0.4 \mathrm{~dB}$ である. $4 \mathrm{KC} の$ noise audiogram は第 2 の型で DL 值は小で ある。

症例：25(R)

闎值上昇が特に著明な $4 \mathrm{KC}(25 \mathrm{~dB}), 6 \mathrm{KC}(20 \mathrm{~dB})$, $8 \mathrm{KC}(30 \mathrm{~dB})$ の noise audiogram 灶々 $2 \mathrm{~A}, 2 \mathrm{~A}$, 2 Cである.

閾值上 $20 \mathrm{~dB}, 30 \mathrm{~dB}$ における DL 值は $1 \mathrm{KC}$ でまま 1. $2 \mathrm{~dB}, 0.8 \mathrm{~dB}$ で， $4 \mathrm{KC}$ では夫々0. $4 \mathrm{~dB}, 0.4 \mathrm{~dB}$ である. $4 \mathrm{KC} の$ noise audiogram は第 2 の型で DL 值は小で ある:

症例 : $25(\mathrm{~L})$

間值上昇が特に著明な $4 \mathrm{KC}(45 \mathrm{~dB}) ， 6 \mathrm{KC}(40 \mathrm{~dB})$ ， $8 \mathrm{KC}(50 \mathrm{~dB})$ の noise audiogram は夫々 $2 \mathrm{~A}, 2 \mathrm{~A}$, 2 Bである:

閔值上 $20 \mathrm{~dB}, 30 \mathrm{~dB}$ における $\mathrm{DL}$ 值は $1 \mathrm{KC}$ では夫々 $0.6 \mathrm{~dB}, 0.6 \mathrm{~dB}$ で， $4 \mathrm{KC}$ では夫々 $0.4 \mathrm{~dB}, 0.4 \mathrm{~dB}$ である. $4 \mathrm{KC} の$ noise audiogram は第2の型で DL 值は小で ある。

症例：26(L)

間值上昇が特に著明な $4 \mathrm{KC}(45 \mathrm{~dB}), 6 \mathrm{KC}(40 \mathrm{~dB})$ ， $8 \mathrm{KC}(50 \mathrm{~dB}) の$ noise audiogram は夫々 $2 \mathrm{E}, 2 \mathrm{E}$, $2 \mathrm{~A}+2 \mathrm{E}$ である:

閾值上 $20 \mathrm{~dB}, 30 \mathrm{~dB}$ における $\mathrm{DL}$ 值は $1 \mathrm{KC}$ でまヶ $0.6 \mathrm{~dB}, 0.6 \mathrm{~dB}$ で， $4 \mathrm{KC}$ では夫々 $0.4 \mathrm{~dB} ， 0.4 \mathrm{~dB}$ である. $4 \mathrm{KC} の$ noise audiogram は第 2 の型で DL 值は小で 西る:

小括 
難聴の原因がメニエル氏病によると思われる9耳の闒 值上昇が特に高度な周波数の noise audiogram は全例 が第2の型を示している。

しかして 4KCでは第1の型を示すものが 2 耳で，第 2 の型を示寸ものが 7 耳である。

次に $1 \mathrm{KC}, 4 \mathrm{KC}$ の閎值上 $20 \mathrm{~dB}, 30 \mathrm{~dB}$ における $\mathrm{DL}$ 值 は次のようである。

$1 \mathrm{KC}$ では閔值上 $20 \mathrm{~dB}, 30 \mathrm{~dB}$ の DL 值は夫々0.6dB, $0.6 \mathrm{~dB}$ から $1.8 \mathrm{~dB} ， 1.2 \mathrm{~dB}$ の間にあり，中等值の䈥围内 にある。

$4 \mathrm{KC}$ では閖値上 $20 \mathrm{~dB}, 30 \mathrm{~dB}$ の DL 值は夫々0.2 $2 \mathrm{~dB}$, $0.2 \mathrm{~dB}$ から1.2dB，1.2dBの間にあり，小の名のが多く， 中等值のものは 3 耳である。

しかして4KC の noise audiogram が第 2 の型を示す 7 耳で DL 值が小のものは6耳であり，中等值のむの 住 1 耳である。第 1 の型を示す 2 耳では DL 值は中等值 であり，その純音閶値は正常である。

次注純音闒值が正常範囲内にあつて, 第 2 の型を示す 23Rの $2 \mathrm{KC}$ と $3 \mathrm{KC}$ がある。

第3節 老人性と考えられる例について

感音䧼㯖で老人性のものと考えられる5例10耳につい て純音閶伯の上昇が特に著明な周波数及び閵値が正常範 囲内にあつて第 2 の型を示す周波数，並びに $1 \mathrm{KC}, 4 \mathrm{KC}$ の閶值上 $20 \mathrm{~dB} ３ 0 \mathrm{~dB}$ における DL 值注次のようである。 症例：27（R）

閔值上昇が特に著明な $8 \mathrm{KC}(75 \mathrm{~dB})$ の noise audiogram は $2 \mathrm{C}$ であり, $4 \mathrm{KC}(20 \mathrm{~dB})$ では第 1 の型であ る.

闒值上 $20 \mathrm{~dB}, 30 \mathrm{~dB}$ における $\mathrm{DL}$ 值は $1 \mathrm{KC}$ では夫ヶ $0.6 \mathrm{~dB}, 1.0 \mathrm{~dB}$ で， $4 \mathrm{KC}$ では夫々 $0.8 \mathrm{~dB}, 0.6 \mathrm{~dB}$ である. $4 \mathrm{KC} の$ noise audiogram 注第 1 の型で $\mathrm{DL}$ 值は中等 值である。

症例 : $27(\mathrm{~L})$

闒值上昇が特に著明な $8 \mathrm{KC}(65 \mathrm{~dB})$ の noise audiogramは2 Cであり４ $4 \mathrm{KC}(30 \mathrm{~dB})$ では第1の型である.

閶值上 $20 \mathrm{~dB}, 30 \mathrm{~dB}$ 亿㧍ける $\mathrm{DL}$ 值は $1 \mathrm{KC}$ では夫タ $0.6 \mathrm{~dB}, 0.6 \mathrm{~dB}$ で， $4 \mathrm{KC}$ では夫々0.6dB，0.4dBである.

$4 \mathrm{KC} の$ noise audiogram は第 1 の型で DL 值は中等 值である。

定例：28(R)

閔值上昇が特に著明な $6 \mathrm{KC}(6 \mathrm{OdB}), 8 \mathrm{KC}(70 \mathrm{~dB})$

の noise audiogram は夫々 $2 \mathrm{~B}, 2 \mathrm{C}$ であり，4KC ( 45 dB) では第1 の型である.

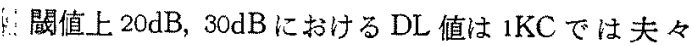
$0.8 \mathrm{~dB}, 0.8 \mathrm{~dB}$ で， $4 \mathrm{KC}$ では夫々 $0.8 \mathrm{~dB}, 0.8 \mathrm{~dB}$ である. $4 \mathrm{KC}$ の noise audiogram は第 1 の型で DL 值は中等 值である。

症例：28（L)

䦭値上灵が特に著明な $6 \mathrm{KC}(65 \mathrm{~dB}) ， 8 \mathrm{KC}(75 \mathrm{~dB})$ の noise audiogram 注何れも第1の型であり,4KC (60 $\mathrm{dB})$ では第 1 の型である。

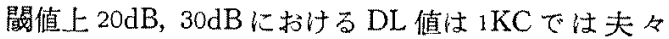
$0.8 \mathrm{~dB}, 0.8 \mathrm{~dB}$ で， $4 \mathrm{KC}$ では夫々0.8dB，0.8dB である.

$4 \mathrm{KC}$ の noise audiogram は第1の型であり, DL 值 は中等值である。

症例 : $29(\mathrm{R})$

閾値上昇が特に著明な $8 \mathrm{KC}(55 \mathrm{~dB})$ の noise audiogramは $2 \mathrm{D} て ゙ あ り ， 4 \mathrm{KC}(30 \mathrm{~dB})$ では第1の型であ る.

闇值上 $20 \mathrm{~dB}, 30 \mathrm{~dB}$ に扔ける $\mathrm{DL}$ 值 $1 \mathrm{KC}$ はでは夫々 $0.6 \mathrm{~dB}, 0.8 \mathrm{~dB}$ で， $4 \mathrm{KC}$ では夫々 $0.6 \mathrm{~dB}, 0.4 \mathrm{~dB}$ である. $4 \mathrm{KC}$ の noise audiogram は第 1 の型で DL 值は中等 值である。

症例 $: 29(\mathrm{~L})$

閭值上昇が特に著明な $8 \mathrm{KC}(50 \mathrm{~dB})$ の noise audio-

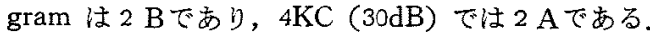

閬值上 $20 \mathrm{~dB}, 30 \mathrm{~dB}$ に扔ける DL 值は $1 \mathrm{KC}$ では夫々 $0.6 \mathrm{~dB}, 0.8 \mathrm{~dB}$ で， $4 \mathrm{KC}$ では夫々0. $4 \mathrm{~dB}, 0.4 \mathrm{~dB}$ である.

$4 \mathrm{KC} の$ noise audiogram は第 2 の型で DL 值は小で ある。

症例：30(R)

閵值上昇が特に著明な $8 \mathrm{KC}$ (70dB) の noise audiogramは $2 \mathrm{C} て ゙ あ り ， 4 \mathrm{KC}(45 \mathrm{~dB})$ で住第1 の型である.

闒值上 $20 \mathrm{~dB}, 30 \mathrm{~dB}$ に扔ける DL 值は $1 \mathrm{KC}$ では夫々 $1.2 \mathrm{~dB}, 1.0 \mathrm{~dB}$ で， $4 \mathrm{KC}$ では夫々 $0.8 \mathrm{~dB}, 0.8 \mathrm{~dB}$ である. $4 \mathrm{KC}$ の noise audiogram は第 19 型で DL 值は中等 值である。

症例：30（L)

閔值上昇が特に著明な $3 \mathrm{KC}(55 \mathrm{~dB}) ， 4 \mathrm{KC}(60 \mathrm{~dB})$, $6 \mathrm{KC}(60 \mathrm{~dB}), 8 \mathrm{KC}(55 \mathrm{~dB})$ D noise audiogram は何 れも2 Еである。

闘值上 $20 \mathrm{~dB}, 30 \mathrm{~dB}$ における DL 值はでは夫々 $1.2 \mathrm{~dB}$ ， 1.0dB で, $4 \mathrm{KC}$ で注夫々0.8dB, 0.6dB である.

$4 \mathrm{KC}$ の noise audiogram 䘟 2 の型で DL 值は中等 值である。

症例：31（R) 
閶值上䒜が特に著明な $3 \mathrm{KC}(50 \mathrm{~dB}), 4 \mathrm{KC}(50 \mathrm{~dB})$ ， $6 \mathrm{KC}(40 \mathrm{~dB}), 8 \mathrm{KC}(50 \mathrm{~dB}) の$ noise audicgram $4 \mathrm{KC}, 6 \mathrm{KC}$ では何机も2 Aであり，8KCでは第 1 の型 である.

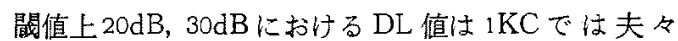
1. $8 \mathrm{~dB}, 1.8 \mathrm{~dB}$ で，4KCでは夫々 $1.6 \mathrm{~dB}, 1.2 \mathrm{~dB}$ である.

$4 \mathrm{KC} の$ noise audiogram は第 2 の型で DL 值は中等 值である.

症例：31（L)

閶値上昇が特に著明な $4 \mathrm{KC}(55 \mathrm{~dB}), 6 \mathrm{KC}(50 \mathrm{~dB})$, $8 \mathrm{KC}(50 \mathrm{~dB}) の$ noise audiogram は夫々第 1 の型, 第 1 の型, 2 Aである.

闇值上 $20 \mathrm{~dB}, 30 \mathrm{~dB}$ に扔ける DL 值は $1 \mathrm{KC}$ では夫ヶ 1. $8 \mathrm{~dB}, 1.4 \mathrm{~dB}$ で， $4 \mathrm{KC}$ では夫快 $4 \mathrm{~dB}, 1.2 \mathrm{~dB}$ である.

$4 \mathrm{KC}$ の noise audiogram は第 1 の型で DL 值怯中等 值である。

\section{小括}

難聴の原因が老人性と思われる10耳の闒值上昇が特に 高度な周波数の noise audiogram は，第 1 の型だけ示 すものが 1 耳，第 2 の型だけ示すものが 7 耳あり，第 1 の型と第 2 の型が合併しているものが 2 耳である。

しかして4KCの noise audiogram は第 1 の型のもの 7 耳，第2の型のもの 3 耳である.

次に $1 \mathrm{KC}, 4 \mathrm{KC}$ の閶值上 $20 \mathrm{~dB}, 30 \mathrm{~dB}$ に括ける $\mathrm{DL}$ 值 は次のようである.

$1 \mathrm{KC}$ では闒值上 $20 \mathrm{~dB}, 30 \mathrm{~dB} の \mathrm{DL}$ 值は夫々 $0.6 \mathrm{~dB}$, $0.6 \mathrm{~dB}$ から $1.8 \mathrm{~dB} ， 1.8 \mathrm{~dB}$ の間にあり，中等值の䇛井内 にある。

$4 \mathrm{KC}$ では閖值上 $20 \mathrm{~dB}, 30 \mathrm{~dB} の \mathrm{DL}$ 值は夫ヶ0. $4 \mathrm{~dB}$, $0.4 \mathrm{~dB}$ から1.6dB，1.2dBの間にあり，多くは中等值の 箐囲内にあり，小のものが 1 耳である。

しかして $4 \mathrm{KC}$ で第1 の型を示す 7 耳では DL 值は中 等值である。第 2 の型を示す 3 耳では DL 值は小のもの が 1 耳，中等値のものが 2 耳である。この 2 耳の DL 值 を仔細に検討すると，1耳に书いては中等値の内では小 の部類である、1耳においては中等値の内では大きい部 類である、

次汇純音閏值が正常範囲内にあつて，第 2 の型を示す ものは本節の症例には認められない。

第 4 節。ストマイ難聴之考えられる例について

感音難聴のらちストマイが原因と考えられる6例11耳 について純音閾値の上昇が特に著明な周波数及び間值が 正常範囲内にあつて第 2 の型を示す周波数，並びに $1 \mathrm{KC}$
$4 \mathrm{KC}$ の閔値上 $20 \mathrm{~dB}, 30 \mathrm{~dB}$ における DL 值は次のようで ある。

\section{症例 : $32(\mathrm{R})$}

閧值上蒋が特に著明な $6 \mathrm{KC}(25 \mathrm{~dB}), 8 \mathrm{KC}(35 \mathrm{~dB})$ の noise audiogram は夫々 $2 \mathrm{~A}, 2 \mathrm{~B} て ゙$ り dB) では第 1 の型である.

䦔值上 $20 \mathrm{~dB}, 30 \mathrm{~dB}$ に扰ける $\mathrm{DL}$ 值住 $1 \mathrm{KC}$ では夫タ $0.6 \mathrm{~dB}, 0.6 \mathrm{~dB}$ で， $4 \mathrm{KC}$ では夫々 $0.6 \mathrm{~dB}, 0.6 \mathrm{~dB}$ である. $4 \mathrm{KC} の$ noise audiogram は第 1 の型で DL 值は中等 值である。

症例 : $32(\mathrm{~L})$

閔值上昇が特に著明な $6 \mathrm{KC}(45 \mathrm{~dB}), 8 \mathrm{KC}(40 \mathrm{~dB})$ の noise audiogram は夫々 $2 \mathrm{~B}+2 \mathrm{E}, 2 \mathrm{E}$ あ゙あり, $4 \mathrm{KC}(30 \mathrm{~dB})$ では $2 \mathrm{~A}+2$ Eである。

閧值上 $20 \mathrm{~dB}, 30 \mathrm{~dB}$ に扔ける $\mathrm{DL}$ 值は $1 \mathrm{KC}$ では夫タ $0.8 \mathrm{~dB}, 0.6 \mathrm{~dB}$ で, $4 \mathrm{KC}$ では夫ฬ0. $6 \mathrm{~dB}, 0.4 \mathrm{~dB}$ である. $4 \mathrm{KC} の$ noise audiogram は第 2 の型で DL 值は中等 值である.

症例：33(R)

關值上昇が特に著明な $1 \mathrm{KC}(25 \mathrm{~dB}) ， 2 \mathrm{KC}(25 \mathrm{~dB})$ ， $3 \mathrm{KC}(30 \mathrm{~dB}), 4 \mathrm{KC}(30 \mathrm{~dB}), 6 \mathrm{KC}(35 \mathrm{~dB}), 8 \mathrm{KC}(30$ dB) の noise audiogram は何れも第1 の型である.

閔值上 $20 \mathrm{~dB}, 30 \mathrm{~dB}$ に㧍ける $\mathrm{DL}$ 值は $1 \mathrm{KC}$ では夫々 $0.6 \mathrm{~dB}, 0.6 \mathrm{~dB}$ で, $4 \mathrm{KC}$ では夫々0.8dB，0.6dBである. $4 \mathrm{KC} の$ noise audiogram 注第 1 の型で DL 值は中等 值である。

症例 : $33(\mathrm{~L})$

䦪值上昇が特に著明な $3 \mathrm{KC}(25 \mathrm{~dB}) ， 4 \mathrm{KC}(30 \mathrm{~dB})$, $6 \mathrm{KC}(35 \mathrm{~dB}), 8 \mathrm{KC}(30 \mathrm{~dB})$ の noise audiogram は夫 々第1の型，第 1 型， $2 \mathrm{~A}$ ，第1の型である.

閔值上 $20 \mathrm{~dB}, 30 \mathrm{~dB}$ に扔ける DL 值は1 $1 \mathrm{KC}$ では夫 $0.6 \mathrm{~dB}, 0.6 \mathrm{~dB}$ で， $4 \mathrm{KC}$ では夫々0.8dB，0.6dB である. $4 \mathrm{KC} の$ noise audiogram は第 1 の型で DL 值壮中等 值である.

症例 : $34(R)$

閶值上昇が特に著明な $3 \mathrm{KC}(45 \mathrm{~dB}) ， 4 \mathrm{KC}(55 \mathrm{~dB})$, $6 \mathrm{KC}(50 \mathrm{~dB}), 8 \mathrm{KC}(55 \mathrm{~dB}) の$ noise audiogram は夫 ヶ $2 \mathrm{~A}, 2 \mathrm{~A}, 2 \mathrm{~B}, 2 \mathrm{~B}$ である.

闒值上 $20 \mathrm{~dB}, 30 \mathrm{~dB}$ における DL 值は $1 \mathrm{KC}$ では夫々 $0.6 \mathrm{~dB}, 0.4 \mathrm{~dB}$ で， $4 \mathrm{KC}$ では夫々 $0.4 \mathrm{~dB}, 0.4 \mathrm{~dB}$ である. 4KC の noise audiogram は第 2 の型で DL 值は小で ある。

症例：34 ( L ) 
閏值上昇が特に著明な $8 \mathrm{KC}(70 \mathrm{~dB})$ の noise audiogramは 2 Cであり， $4 \mathrm{KC}(45 \mathrm{~dB})$ では第1の型であ 万.

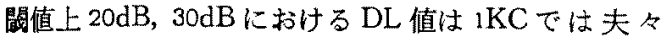
$0.6 \mathrm{~dB}, 0.4 \mathrm{~dB}$ で, $4 \mathrm{KC}$ では夫々0. $4 \mathrm{~dB}, 0.4 \mathrm{~dB}$ である.

4KC の noise audiogram は第 1 の型で DL 值は小で あ。

症例 : $35(\mathrm{R})$

閏值上㫒が特に著明な $1 \mathrm{KC}(40 \mathrm{~dB}) ， 2 \mathrm{KC}(45 \mathrm{~dB})$ ， $3 \mathrm{KC}(40 \mathrm{~dB}), 4 \mathrm{KC}(40 \mathrm{~dB}), 6 \mathrm{KC}(40 \mathrm{~dB}), 8 \mathrm{KC}(40$ $\mathrm{dB})$ noise audiogram は夫々 $2 \mathrm{~A}, 2 \mathrm{~A}, 2 \mathrm{~A}, 2$ A，第1の型， 2 Aである.

閶值上 $20 \mathrm{~dB}, 30 \mathrm{~dB}$ における DL 值は $1 \mathrm{KC}$ では々 $0.8 \mathrm{~dB}, 0.6 \mathrm{~dB}$ で, $4 \mathrm{KC}$ では夫々0.8dB，0.6dB である. $4 \mathrm{KC} の$ noise audiogram は第 2 の型で DL 值は中等 値である.

症例 : $35(\mathrm{~L})$

闘値上昇吕特に著明な $1 \mathrm{KC}(40 \mathrm{~dB}), 2 \mathrm{KC}(40 \mathrm{~dB})$, $3 \mathrm{KC}(40 \mathrm{~dB}), 4 \mathrm{KC}(40 \mathrm{~dB}), 6 \mathrm{KC}(40 \mathrm{~dB}), 8 \mathrm{KC}(40$ dB) のnoise audiogram は夫々 $2 \mathrm{~A}$, 第 1 の型, $2 \mathrm{~A}$, 第1の型，2 A， 2 Eである。

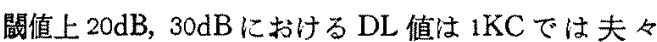
$0.6 \mathrm{~dB}, 0.6 \mathrm{~dB}$ で， $4 \mathrm{KC}$ では夫々 $0.6 \mathrm{~dB}, 0.6 \mathrm{~dB}$ である. $4 \mathrm{KC} の$ noise audiogram は第 1 の型で DL 值は中等 值である。

症例 : $36(\mathrm{R})$

闘值上帠が特に著明な $6 \mathrm{KC}(30 \mathrm{~dB}), 8 \mathrm{KC}(30 \mathrm{~dB})$ の noise audiogram は何れも $2 \mathrm{~A}+2 \mathrm{E}$ であり，4KC（10 dB) では第 1 の型である。

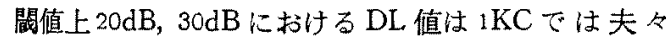
$1.0 \mathrm{~dB}, 0.6 \mathrm{~dB}$ で, $4 \mathrm{KC}$ では夫々 $0.8 \mathrm{~dB}, 0.8 \mathrm{~dB}$ である. $4 \mathrm{KC} の$ noise audiogram は第 1 の型で DL 值は中等 值である。

\section{症例: 37 (R)}

閖値上昇㔔特に著明な6 $\mathrm{KC}(55 \mathrm{~dB}), 8 \mathrm{KC}(50 \mathrm{~dB})$ の noise audiogram は何れも $2 \mathrm{Cであり，4KC} \mathrm{(35dB)}$ では 2 Bである。

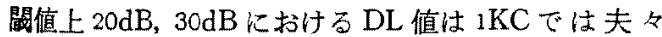
$0.6 \mathrm{~dB}, 0.6 \mathrm{~dB}$ で，4KCでは夫々 $1.2 \mathrm{~dB}, 0.8 \mathrm{~dB}$ である. $4 \mathrm{KC} の$ noise audiogram は第 2 の型で DL 值は中等 值である。

症例37 (L)

閶値上昇が特に著明な $6 \mathrm{KC}(45 \mathrm{~dB}) ， 8 \mathrm{KC}(55 \mathrm{~dB})$
の noise audiogramは夫ヶ $2 \mathrm{~B}, 2 \mathrm{C} て ゙ あ り, 4 \mathrm{KC}(20$ dB) では第1の型である。

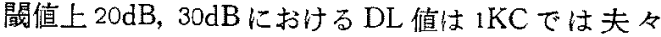
1. $6 \mathrm{~dB}, 1.2 \mathrm{~dB}$ で, $4 \mathrm{KC}$ では夫љ0. $6 \mathrm{~dB}, 0.6 \mathrm{~dB}$ である. $4 \mathrm{KC} の$ noise audiogram は第 1 の型で DL 值は中等 值である。

小括

難聴の原因がストマイによると思われる11耳の闘值上 昇が特に高度な周波数の noise audiogram は第 1 の型 交示すのは1耳であり，第2の型六すものは7耳で あり，第1 の型と第 2 の型が合併しているものは 3 耳で ある

しかして4KCの noise audiogram は第1の型のもの 7 耳で，第 2 型のものは 4 耳である，

次に $1 \mathrm{KC}, 4 \mathrm{KC}$ の閶値上 $20 \mathrm{~dB}, 30 \mathrm{~dB}$ におる DL 值 は次のようで亦る。

$1 \mathrm{KC}$ では閶值上 $20 \mathrm{~dB}, 30 \mathrm{~dB}$ の DL值は夫々0. $6 \mathrm{~dB}$ ， $0.6 \mathrm{~dB}$ から $1.6 \mathrm{~dB}, 1.2 \mathrm{~dB} の \mathrm{DL}$ 間にあり，中等值の範 用内にある。

$4 \mathrm{KC}$ では閔值上 $20 \mathrm{~dB}, 30 \mathrm{~dB} の \mathrm{DL}$ 值は夫々0. $4 \mathrm{~dB}$, $0.4 \mathrm{~dB}$ から $1.2 \mathrm{~dB}, 0.8 \mathrm{~dB} の$ 閒にあり, 多くは中等值の 範囲内にあるが，小のものも2耳るる。

しかして $4 \mathrm{KC}$ で第1の型を示す7耳では DL 值は中 等值のものが6耳，小のものが 1 耳である，第 2 の型を 示す4耳では DL 值が中等值のものは 3 耳，小のものが 1 耳である。

第 2 の型で DL 值が中等值のもの DL の值を仔細に検 討すると， 2 耳においては中等做の内では小さい部類で ある、1耳においては中等值である。

次に純音閶值が正常範围にあつて，第2の型を示する のは本節の症例に住認められない。

第 5 節 頭部外傷例について

感音難聴のうち，頭部外傷によると考えられる10例14 耳について純音閔值の上昇が特に著明な周波数及じ閶值 が正常範囲内にあつて第 2 の型走示す周波数，並びに $1 \mathrm{KC}, 4 \mathrm{KC}$ の關值上 $20 \mathrm{~dB} ， 30 \mathrm{~dB}$ における DL 值は次の ようである。

症例：38(L)

閔值上昇が特に著明な $6 \mathrm{KC}(50 \mathrm{~dB}), 8 \mathrm{KC}(50 \mathrm{~dB})$ の noise audiogram は夫々 $2 \mathrm{~A}, 2 \mathrm{~B}+2 \mathrm{E}$ ばあ， $4 \mathrm{KC}(30 \mathrm{~dB})$ では第1 の型である。

䦪值上 $20 \mathrm{~dB}, 30 \mathrm{~dB}$ における $\mathrm{DL}$ 值は $1 \mathrm{KC}$ では夫タ $0.6 \mathrm{~dB}, 0.6 \mathrm{~dB}$ で, $4 \mathrm{KC}$ では夫々0.6dB，0. $4 \mathrm{~dB}$ である. 
4KC の noise audiogram は第 1 の型で DL 值は中等 值である。

\section{症例: 39 ( $\mathrm{R}$ )}

閏值上昇が特に都明な $6 \mathrm{KC}(60 \mathrm{~dB}) の$ noisc audiogram は $2 \mathrm{C}$ であり，4KC (45dB) では 2 Aである.

間值上 $20 \mathrm{~dB} ３ 0 \mathrm{~dB}$ におり $\mathrm{DL}$ 值は $1 \mathrm{KC}$ では々 1. $2 \mathrm{~dB}, 1.0 \mathrm{~dB}$ で, $4 \mathrm{KC}$ では夫々0.8dB, 0.6dBである. $4 \mathrm{KC} の$ noise audiogram は第 2 の型で DL 值は中等 値である。

症例：40（L)

閥值上昇が特に著明な6 KC $(40 \mathrm{~dB}), 8 \mathrm{KC}(50 \mathrm{~dB})$ の noise audiogram は夫第 1 の型, $2 \mathrm{~A}$ であり, $4 \mathrm{KC}$ (30dB) では第 1 の型である.

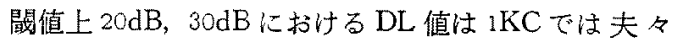
$0.8 \mathrm{~dB}, 0.6 \mathrm{~dB}$ で, $4 \mathrm{KC}$ では夫々0.6dB，0.6dBである.

$4 \mathrm{KC}$ noise audiogram は第 1 の型で DL 值は中等 値である。

\section{症例 : 41 ( $\mathrm{R}$ )}

閶值上昇が特に著明な $4 \mathrm{KC}(60 \mathrm{~dB}), 6 \mathrm{KC}(65 \mathrm{~dB})$ ，

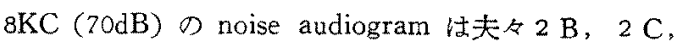
2 Dである。

闌值上 $20 \mathrm{~dB}, 30 \mathrm{~dB}$ における DL 值は $1 \mathrm{KC}$ な夫夕 $1.2 \mathrm{~dB}, 1.0 \mathrm{~dB}$ で, $4 \mathrm{KC}$ では夫々0.6dB, 0.6dBである. $4 \mathrm{KC} の$ noise audiogram は第 2 型で DL 值は中等 值である。

\section{症例 : 41（L)}

䦥値上昇が特に著明な $6 \mathrm{KC}(70 \mathrm{~dB}), 8 \mathrm{KC}(75 \mathrm{~dB})$ の noise audiogram は $6 \mathrm{KC}$ では $2 \mathrm{E}, 8 \mathrm{KC}$ では検查でき ず, $4 \mathrm{KC}(60 \mathrm{~dB})$ では 2 Bである.

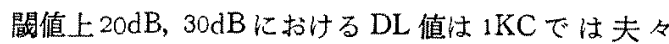
1. $\mathrm{OdB}, 1 . \mathrm{OdB}$ で, $4 \mathrm{KC}$ では夫々0.4dB，0.4dBである. $4 \mathrm{KC} の$ noise audiogram は第 2 の型で DL 值は小で ある。

\section{症例：42(L)}

間倠上暑方特に著明な $8 \mathrm{KC}(35 \mathrm{~dB})$ の noisc audiogramは $2 \mathrm{E}$ であり，4KC (1odB) では第1の型であ る.

閶傎上 $20 \mathrm{~dB}, 30 \mathrm{~dB}$ に括ける DL 值は1 $\mathrm{KC}$ で夫々 $1.4 \mathrm{~dB}, 0.8 \mathrm{~dB}$ で, $4 \mathrm{KC}$ では夫々0.8dB，0.8dBである. $4 \mathrm{KC}$ の noise audiogram は第 1 の型で $\mathrm{DL}$ 值は中等 值である。

症例: $43(\mathrm{R})$

閾值上界が特に著明な $6 \mathrm{KC}(40 \mathrm{~dB}), 8 \mathrm{KC}(50 \mathrm{~dB}) の$ noise audiogram は夫々 $2 \mathrm{~B}, 2 \mathrm{D}$ な゙あり，4KC (15 dB) では第 1 の型である.

闒值上 $20 \mathrm{~dB}, 30 \mathrm{~dB}$ に扝ける DL 值は $1 \mathrm{KC}$ では夫

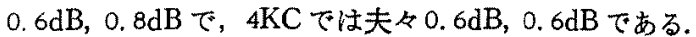
$4 \mathrm{KC} の$ noise audiogram は第 1 の型で DL 值は中等 值である。

症例：44(R)

閶値上开が特に著明な $1 \mathrm{KC}(75 \mathrm{~dB}), 3 \mathrm{KC}(80 \mathrm{~dB})$, $4 \mathrm{KC}(80 \mathrm{~dB}), 6 \mathrm{KC}(70 \mathrm{~dB}), 8 \mathrm{KC}(70 \mathrm{~dB}) の$ noise audiogram は $1 \mathrm{KC}$ では第 1 の型，3KC，4KC，6KC，8 $\mathrm{KC}$ では检査不能である。

闒值上 $20 \mathrm{~dB}, 30 \mathrm{~dB}$ に括ける DL 值は $1 \mathrm{KC}, 4 \mathrm{KC}$ 何れ む検查不能である。

$4 \mathrm{KC} の$ noise audiogram, DL 值は検查不能である. 症例 : 44 (L)

閶值上界が特に著明な $1 \mathrm{KC}(60 \mathrm{~dB}) ， 3 \mathrm{KC}(65 \mathrm{~dB})$ ， $4 \mathrm{KC}(70 \mathrm{~dB}), 6 \mathrm{KC}(65 \mathrm{~dB}), 8 \mathrm{KC}(65 \mathrm{~dB})$ の noise audiogram は何れも第1 の型である。

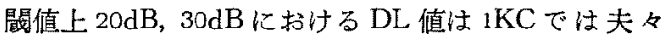
$0.6 \mathrm{~dB}, 0.8 \mathrm{~dB}$ で， $4 \mathrm{KC}$ では闏值上 $20 \mathrm{~dB} て ゙ 0.6 \mathrm{~dB}$ ，闘值 上 $30 \mathrm{~dB}$ では検査不能である。

$4 \mathrm{KC} の$ noise audiogram は第 1 の型で $\mathrm{DL}$ 值は中等 值である。

症例: 45 (R)

閣值上算が特に著明な $3 \mathrm{KC}(75 \mathrm{~dB}) ， 4 \mathrm{KC}(85 \mathrm{~dB})$, $6 \mathrm{KC}(75 \mathrm{~dB}), 8 \mathrm{KC}(75 \mathrm{~dB})$ の noise audiogram $13 \mathrm{KC}$ $4 \mathrm{KC}, 6 \mathrm{KC}$ では第1 の型, $8 \mathrm{KC}$ では検查不能である.

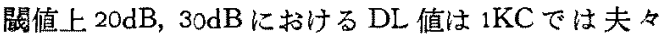
0. $4 \mathrm{~dB}, 0.4 \mathrm{~dB}$ で， $4 \mathrm{KC}$ では夫々検查不能である。

$4 \mathrm{KC} の$ noise audiogram は第 1 の型で DL 值は検查 不能である。

症例：45(L)

閖值上年が特に著明な $6 \mathrm{KC}(30 \mathrm{~dB}) ， 8 \mathrm{KC}(40 \mathrm{~dB})$ の noise audiogram は夫々第1 の型, 2 Aであり，4KC (20dB) では第 1 の型である。

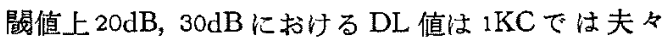
$0.8 \mathrm{~dB}, 1.0 \mathrm{~dB}$ で, $4 \mathrm{KC}$ では夫々 $1.0 \mathrm{~dB}, 1.0 \mathrm{~dB}$ である. $4 \mathrm{KC}$ の noise audiogram は第 1 の型で DL 值は中等 値である。

症例: $46(\mathrm{R})$

閖值上昇が特に著明な $4 \mathrm{KC}(45 \mathrm{~dB}), 6 \mathrm{KC}(40 \mathrm{~dB}) \emptyset$

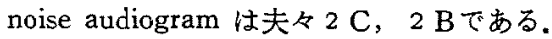

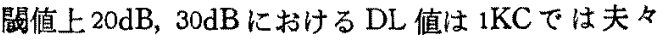


1. $8 \mathrm{~dB}, 1.4 \mathrm{~dB}$ で, $4 \mathrm{KC}$ では夫々1.6 $6 \mathrm{~dB}, 1.2 \mathrm{~dB}$ である. $4 \mathrm{KC}$ のoise audiogram は第 2 の型で DL 值は中等 值である。

症例: $46(\mathrm{~L})$

闒值上昇が特に著明な $4 \mathrm{KC}(65 \mathrm{~dB})$ の noise audiogram は 2 A である。

閶值上 $20 \mathrm{~dB}, 30 \mathrm{~dB}$ における DL 值は1KCでは夫々 $1.6 \mathrm{~dB}, 1.6 \mathrm{~dB}$ で， $4 \mathrm{KC}$ で注閔值上 $20 \mathrm{~dB}$ で $1.6 \mathrm{~dB}$, 聞值 上30dBでは検查不能である。

$4 \mathrm{KC} の$ noise audiogram は第 2 型で DL 值は中等 值である。

定例: 47 (L)

間值上昇が特に著明な $6 \mathrm{KC}(55 \mathrm{~dB})$ の noise audio-

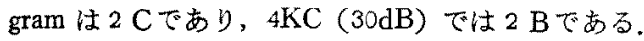

關值上 $20 \mathrm{~dB}, 30 \mathrm{~dB}$ における DL 值は $1 \mathrm{KC}$ で夫々

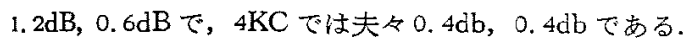

4KC の noise audiogram は第 2 の型で DL 值は小で ある。

\section{小 括}

難㯖の原因が頭部外傷によると思われる14耳の閶值上 昇吕特に高度な周波数の noise audiogram は, 第 1 の型 交示すのは 3 耳であり，第 2 の型を示すものは 9 耳で あり，第 1 の型と第 2 の型を合併しているものは 2 耳で ある。

しかして 4KC の noise audiogram 恃第 1 の型を示す すのは 7 耳であり，第2の型を示すものは6耳である。 検查不能のものは1耳である。

次に $1 \mathrm{KC}, 4 \mathrm{KC}$ の閶值上 $20 \mathrm{~dB}, 30 \mathrm{~dB} に お け る \mathrm{DL}$ 值 は次のようである。

$1 \mathrm{KC}$ て葳值上 $20 \mathrm{~dB}, 30 \mathrm{~dB}$ の DL 值は夫々 $0.4 \mathrm{~dB}$, $0.4 \mathrm{~dB}$ から $1.8 \mathrm{~dB}, 1.6 \mathrm{~dB} の$ 間にあり，多くは中等値の 範因内にあるが，小のものも1耳るる。

$4 \mathrm{KC}$ で閶值上 $20 \mathrm{~dB}, 30 \mathrm{~dB} の \mathrm{DL}$ 值は夫々0.4dB， $0.4 \mathrm{~dB}$ から $1.6 \mathrm{~dB}, 1.2 \mathrm{~dB}$ の間にあり，多くは中等值の 籍囲内にあるが，小のものも2耳るる。

しかして $4 \mathrm{KC}$ で第 1 の型のもの 7 耳では DL 值は中 等值のもの6耳で，検查不能のもの仕 1 耳である。第 2 の型のもの6耳では DL 值は中等值のものは 4 耳で，小 のものは 2 耳である。

第 2 型で DL 值が中等值のものの DL 值を付細に検 討すると， 2 耳においては中等值の内では小さい部類で ある、2耳においては中等值である、

$4 \mathrm{KC}$ で noise audiogram と DL 值が検查不能のもの
1 耳（44R）がある。

次に継音間值が正常範囲内にあつて，第 2 の型を示す 周波数は，本節の症例には認められない.

第 6箕 原因不明の難㯖について

感音難聴の5ち，原因を明らかにし得ない40例22耳に ついて純音閾值の上昇が特に著明な周波数及び閶值が正 常範囲内にあつて第 2 の型を示す周波数，並びに $1 \mathrm{KC}$ ， $4 \mathrm{KC}$ の閏值上 $20 \mathrm{~dB}$ と $30 \mathrm{~dB}$ に和ける DL 值は次のよ 5 である。

症例: $48(\mathrm{R})$

闇值上昇が特に著明な $1 \mathrm{KC}(70 \mathrm{~dB}) ， 2 \mathrm{KC}(70 \mathrm{~dB})$ ， $3 \mathrm{KC}(65 \mathrm{~dB}), 4 \mathrm{KC}(75 \mathrm{~dB}), \quad 6 \mathrm{KC}(70 \mathrm{~dB}), \quad 8 \mathrm{KC}(65$ dB) の noise audiogram は何れも第1の型である。

䦨值上 $20 \mathrm{~dB}, 30 \mathrm{~dB}$ における $\mathrm{DL}$ 值は $1 \mathrm{KC}$ では闒値上 $20 \mathrm{~dB}$ で壮0. $6 \mathrm{~dB}$, 䦪值上 $30 \mathrm{~dB}$ で㳉検查不能で， $4 \mathrm{KC}$ で は夫々検查不能である。

$4 \mathrm{KC}$ のoise audiogram は第1 の型で DL 值は検查 できない.

莚例 : 48 (L)

上昇が特に著明な $2 \mathrm{KC}(80 \mathrm{~dB}) ， 3 \mathrm{KC}(70 \mathrm{~dB}) ， 4 \mathrm{KC}$ (70dB) の noise audiogram は何れも2 Aである.

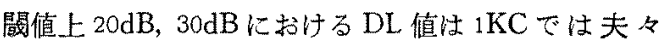
$0.6 \mathrm{~dB}, 0.6 \mathrm{~dB}$ で， $4 \mathrm{KC}$ では闒值上 $20 \mathrm{~dB}$ では0. $6 \mathrm{~dB}$ ，闒 值上 $30 \mathrm{~dB}$ では検査不能である。

$4 \mathrm{KC} の$ noise audiogram 注第 2 の型で DL 值は中等 值である:

症例：49(R)

間值上萃が特に著明方 $1 \mathrm{KC}(40 \mathrm{~dB}), 2 \mathrm{KC}(45 \mathrm{~dB})$, $3 \mathrm{KC}(50 \mathrm{~dB}), 4 \mathrm{KC}(50 \mathrm{~dB}), 6 \mathrm{KC}(45 \mathrm{~dB}), 8 \mathrm{KC}(45$ dB) の noise audiogram 注何れも第1の型である.

閶值上 $20 \mathrm{~dB}, 30 \mathrm{~dB}$ における DL 值は $1 \mathrm{KC}$ な゙ 々 $0.6 \mathrm{~dB}, 0.6 \mathrm{~dB}$ で， $4 \mathrm{KC}$ では夫々0.6dB，0.6dB である. $4 \mathrm{KC} の$ noise audiogram は第 1 の型で DL 值は中等 值である。

症例 : 49 (L)

聞值上界が特に著明な $1 \mathrm{KC}(40 \mathrm{~dB}), 2 \mathrm{KC}(40 \mathrm{~dB})$, $3 \mathrm{KC}(45 \mathrm{~dB}), 4 \mathrm{KC}(50 \mathrm{~dB}), 6 \mathrm{KC}(45 \mathrm{~dB}), \quad 8 \mathrm{KC}(45$ dB)の noise audiogram は何れも第 1 の型である.

閔值上 $20 \mathrm{~dB}, 30 \mathrm{~dB}$ における DL 值は $1 \mathrm{KC}$ ではょ $0.8 \mathrm{~dB}, 0.6 \mathrm{~dB}$ で, $4 \mathrm{KC}$ では夫々 $0.6 \mathrm{~dB}, 0.6 \mathrm{~dB}$ である. $4 \mathrm{KC} の$ noise audiogram は第 1 の型で DL 值は中等 值である。

症例：50( $\mathrm{R}$ ) 
間值上㫒が特に著明な $4 \mathrm{KC}(55 \mathrm{~dB}), 6 \mathrm{KC}(55 \mathrm{~dB})$, $8 \mathrm{KC}(60 \mathrm{~dB})$ の noise audiogram は夫々 $2 \mathrm{~B}, 2 \mathrm{~B}$, $2 \mathrm{~A}+2 \mathrm{E}$ である.

䦔值上 $20 \mathrm{~dB}, 30 \mathrm{~dB}$ に拉ける DL 值は $1 \mathrm{KC}$ では夫

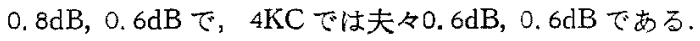
$4 \mathrm{KC}$ の noise audiogram は第 2 の型で DL 值は中等 值である、

\section{症例：51（R)}

闣值上昇が特に著明な $4 \mathrm{KC}(15 \mathrm{~dB}), 6 \mathrm{KC}(25 \mathrm{~dB})$ の noise audiogram は夫々第 1 の型, $2 \mathrm{~A} ゙$ でる.

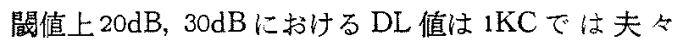
$0.8 \mathrm{~dB}, 0.8 \mathrm{~dB}$ で， $4 \mathrm{KC}$ では0.8dB，0.6dBである。

$4 \mathrm{KC} の$ noise audiogram は第 1 の型で DL 值は中等 值である。

\section{症例 : $51(\mathrm{~L})$}

闖值上昇が特に著明な $4 \mathrm{KC}(50 \mathrm{~dB}), 6 \mathrm{KC}(50 \mathrm{~dB})$, $8 \mathrm{KC}(45 \mathrm{~dB})$ の noise audiogram は夫ヶ $2 \mathrm{D}, 2 \mathrm{D}$, $2 \mathrm{E}$ である.

閶值上 $20 \mathrm{~dB}, 30 \mathrm{~dB}$ に㧍ける DL 值は $1 \mathrm{KC}$ では夫々 $0.8 \mathrm{~dB}, 0.8 \mathrm{~dB}$ で, $4 \mathrm{KC}$ では夫々 $0.4 \mathrm{~dB}, 0.4 \mathrm{~dB}$ である. $4 \mathrm{KC} の$ noise audiogram は第 2 の型で DL 值は小で ある。

\section{症例：52（R)}

闇値上第が特に著明な $3 \mathrm{KC}(60 \mathrm{~dB}) ， 4 \mathrm{KC}(70 \mathrm{~dB})$, 8KC (7OdB) の noise audiogram は何れも第 1 の型で ある。

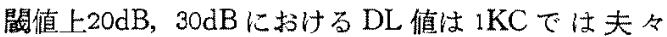
$0.8 \mathrm{~dB}, 0.8 \mathrm{~dB}$ で， $4 \mathrm{KC}$ では闇值上 $20 \mathrm{~dB}$ では0.8dB, 閔 值上 $30 \mathrm{~dB}$ では検查不能である。

$4 \mathrm{KC} の$ noise audiogram は第 1 の型で DL 值は中等 值である.

症例 : $52(\mathrm{~L})$

閶值上昇が特に著明な $3 \mathrm{KC}(75 \mathrm{~dB}), 4 \mathrm{KC}(80 \mathrm{~dB})$, $8 \mathrm{KC}$ (80dB 以上)の noise audiogram は3KC, $4 \mathrm{KC}$ で は何れも2 A, 8KC では検査不能である。

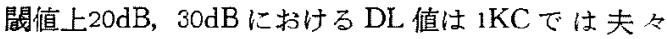
$0.6 \mathrm{~dB}, 0.6 \mathrm{~dB}$ で， $4 \mathrm{KC}$ では夫々検查不能である.

$4 \mathrm{KC} の$ noise audiogram は第 2 の型で DL 值は検查 不能である.

\section{症例 : $53(\mathrm{R})$}

闒值上昇が特に著明な $3 \mathrm{KC}(35 \mathrm{~dB}), 4 \mathrm{KC}(45 \mathrm{~dB})$, $6 \mathrm{KC}(35 \mathrm{~dB}) の$ noise audiogram は夫々 $2 \mathrm{~A}, 2 \mathrm{~A}$, 第1の型である.
閵值上 $20 \mathrm{~dB} ， 30 \mathrm{~dB}$ における $\mathrm{DL}$ 值は $1 \mathrm{KC}$ では夫々

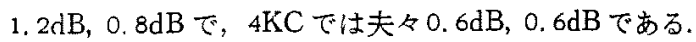
$4 \mathrm{KC} の$ noise audicgram は第 2 型で DL 值は中等 值である。

症例 : $53(\mathrm{~L})$

闎值上昇が特に著明な $3 \mathrm{KC}(40 \mathrm{~dB}), 4 \mathrm{KC}(45 \mathrm{~dB})$, $6 \mathrm{KC}(4 \mathrm{OdB}), 8 \mathrm{KC}(4 \mathrm{OdB})$ のnoise audiogram 注何れ も第 1 の型である。

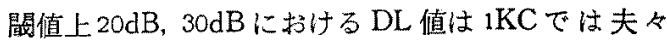
1. $2 \mathrm{~dB}, 0.8 \mathrm{~dB}$ で, $4 \mathrm{KC}$ では夫々 $0.6 \mathrm{~dB}, 0.6 \mathrm{~dB}$ である. $4 \mathrm{KC}$ の noise audiogram 注第 1 の型で DL 値住中等 值である。

症例: $54(\mathrm{R})$

閔值上昇が特に著明な $3 \mathrm{KC}(65 \mathrm{~dB}), 4 \mathrm{KC}(65 \mathrm{~dB})$ の noise audiogram は何れも2 Cである.

閔值上 $20 \mathrm{~dB}, 30 \mathrm{~dB}$ 亿㧍ける DL 值は $1 \mathrm{KC}$ では々 $0.8 \mathrm{~dB}, 0.6 \mathrm{~dB}$ で， $4 \mathrm{KC}$ では閶值上 $20 \mathrm{~dB}$ で0.6 $6 \mathrm{~dB}$, 關值 上 $30 \mathrm{~dB}$ で検查不能である.

$4 \mathrm{KC} の$ noise audiogram は第 2 の型で DL 值は中等 值である。

症例：54(L)

閶值上昇が特に著明な $3 \mathrm{KC}(65 \mathrm{~dB}) ， 4 \mathrm{KC}(55 \mathrm{~dB})$, $6 \mathrm{KC}(60 \mathrm{~dB})$ の noise audiogram は夫々 $2 \mathrm{~B}, 2 \mathrm{~A}$, 第 1 の型である.

閔值上 $20 \mathrm{~dB}, 30 \mathrm{db}$ に扔ける DL 值は $1 \mathrm{KC}$ でまタ $0.6 \mathrm{~dB}, 0.6 \mathrm{~dB}$ で， $4 \mathrm{KC}$ では夫々0.6dB，0.6dB である. $4 \mathrm{KC} の$ noise audiogram は第 2 の型で $\mathrm{DL}$ 值は中等 值である。

症例 : $55(\mathrm{R})$

闒值上昇が特に著明な $3 \mathrm{KC}(50 \mathrm{~dB}) ， 4 \mathrm{KC}(50 \mathrm{~dB})$, $6 \mathrm{KC}(50 \mathrm{~dB}), 8 \mathrm{KC}(60 \mathrm{~dB})$ onoise audiogram $13 \mathrm{KC}$,

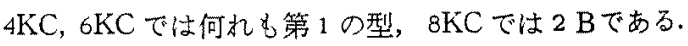
闇值上 $20 \mathrm{~dB}, 30 \mathrm{~dB}$ に扝ける DL 值は $1 \mathrm{KC}$ では夫々 0. $4 \mathrm{~dB}, 0.4 \mathrm{~dB}$ で， $4 \mathrm{KC}$ では夫々0. $4 \mathrm{~dB}, 0.4 \mathrm{~dB}$ である. $4 \mathrm{KC} の$ noise audiogram 汶第 1 の型で DL 值は小で ある.

\section{症例 : $55(\mathrm{~L})$}

閵值上昇が特に著明な $2 \mathrm{KC}(45 \mathrm{~dB}), 3 \mathrm{KC}(50 \mathrm{~dB})$, $4 \mathrm{KC}(55 \mathrm{~dB}), \quad 6 \mathrm{KC}(50 \mathrm{~dB}), \quad 8 \mathrm{KC}(45 \mathrm{db})$ の noise audiogram は何礼も第1の型である。

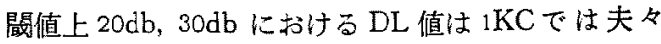
$0.6 \mathrm{~dB}, 0.4 \mathrm{~dB}$ で， $4 \mathrm{KC}$ では夫々 $0.6 \mathrm{~dB}, 0.4 \mathrm{~dB}$ である. $4 \mathrm{KC} の$ noise audiogram は第 1 の型で DL 值は中等 
倠である。

症例: $56(\mathrm{R})$

間值上昇が特に著明な $8 \mathrm{KC}(45 \mathrm{~dB})$ の noise audiogram は 2 Cであり, $4 \mathrm{KC}(25 \mathrm{~dB})$ では $2 \mathrm{~A} ゙$ ある。

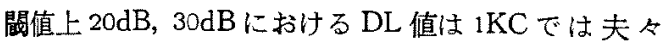
$1.8 \mathrm{~dB}, 0.8 \mathrm{~dB}$ で, $4 \mathrm{KC}$ では夫々 $1.0 \mathrm{~dB}, 0.6 \mathrm{~dB}$ である. $4 \mathrm{KC} の$ noise audiogram は第 2 の型で DL 值は中等值 である。

症例: $56(\mathrm{~L})$

閶值上昗が特に著明な $8 \mathrm{KC}(45 \mathrm{~dB})$ の noise audiogram 2 Cであり，4KC (25dB) では第1の型であ 万.

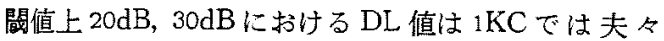
$1.2 \mathrm{~dB}, 1.2 \mathrm{~dB}$ で, $4 \mathrm{KC}$ では夫々0. $8 \mathrm{~dB}, 0.6 \mathrm{~dB}$ である.

$4 \mathrm{KC}$ のoise audiogram は第 1 の型で DL 值は中等 偅である.

症例: $57(\mathrm{R})$

閶值上昇が特に著明な $4 \mathrm{KC}(40 \mathrm{~dB}) ， 6 \mathrm{KC}(4 \mathrm{OdB})$, $8 \mathrm{KC}(50 \mathrm{~dB}) の$ noise audiogram は夫ヶ $2 \mathrm{~A}$, 第 $1 の$ 型，2 Eである。

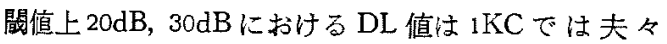
$1.0 \mathrm{~dB}, 0.8 \mathrm{~dB}$ で, $4 \mathrm{KC}$ では夫々 $1.0 \mathrm{~dB}, 1.0 \mathrm{~dB}$ である. $4 \mathrm{KC}$ の noise audiogram は第 2 の型で DL 值は中等 值である。

症例: 57 (L)

閶值上昇が特に著明な $8 \mathrm{KC}(65 \mathrm{~dB})$ の noise audio-

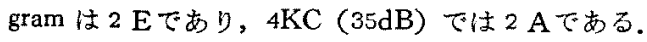

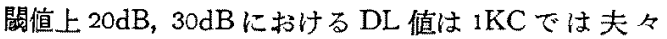
$0.8 \mathrm{~dB}, 1.0 \mathrm{~dB}$ で, $4 \mathrm{KC}$ では夫々0. $8 \mathrm{~dB}, 0.6 \mathrm{~dB}$ である.

$4 \mathrm{KC}$ の noise audiogram は第 2 の型で DL 值は中等 侟である。

症例: $58(\mathrm{~L})$

閶值上界が特に著明な $4 \mathrm{KC}(55 \mathrm{~dB}), 6 \mathrm{KC}(55 \mathrm{~dB})$, $8 \mathrm{KC}(55 \mathrm{~dB}) の$ noise andiogram は夫々 $2 \mathrm{~A}+2 \mathrm{E}$, $2 \mathrm{C}+2 \mathrm{E}, 2 \mathrm{D}$ である。

閧值上 $20 \mathrm{~dB}, 30 \mathrm{~dB}$ における $\mathrm{DL}$ 值は $1 \mathrm{KC}$ では夫

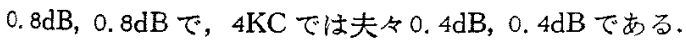
$4 \mathrm{KC}$ の noise audiogram は第 2 の型で DL 值は小で ある。

症例: $59(\mathrm{R})$

䦥值上昇が特に著明な $2 \mathrm{KC}(60 \mathrm{~dB}) ， 3 \mathrm{KC}(60 \mathrm{~dB})$, $4 \mathrm{KC}(60 \mathrm{~dB}), 6 \mathrm{KC}(65 \mathrm{~dB}), 8 \mathrm{KC}(65 \mathrm{~dB})$ の noise audiogram は何れも第 1 の型である。
閶值上 $20 \mathrm{~dB}, 30 \mathrm{~dB}$ における DL 值は $1 \mathrm{KC}$ では夫ヶ 1.0dB, 1. $8 \mathrm{~dB}$ で, $4 \mathrm{KC}$ では夫々 1. $4 \mathrm{~dB}, 1.4 \mathrm{~dB}$ である。 $4 \mathrm{KC}$ の noise audiogram は第1 の型で DL 值は中等 値である。

症例 : 59 (L)

間值上昇が特に著明な $4 \mathrm{KC}(60 \mathrm{~dB}) ， 6 \mathrm{KC}(60 \mathrm{~dB})$, $8 \mathrm{KC}(70 \mathrm{~dB})$ の noise audiogram は何れも第 1 の型で ある。

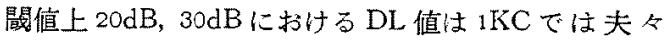
1. $4 \mathrm{~dB}, 1.4 \mathrm{~dB}$ で， $4 \mathrm{KC}$ では夫々 1. $4 \mathrm{~dB}, 1.4 \mathrm{~dB}$ である。 $4 \mathrm{~F}_{\mathrm{X}} \mathrm{C}$ のnoise audiogram は第 1 の型で DL 值は中等值 である。

症例：60(L)

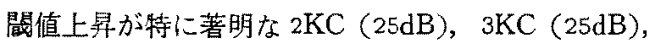
$4 \mathrm{KC}(25 \mathrm{~dB}), 6 \mathrm{KC}(30 \mathrm{~dB}), 8 \mathrm{KC}(35 \mathrm{~dB})$ の noise audiogram は $2 \mathrm{KC}, 3 \mathrm{KC}, 4 \mathrm{KC}, 6 \mathrm{KC}$ では何机子第 1 の 型で, 8KCでは2 Bである。

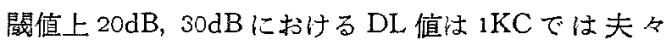
1.0dB, 1.0dBで, $4 \mathrm{KC}$ では夫々1.0db, 0.8dbである. $4 \mathrm{KC} の$ noise audiogram 第 1 の型で DL 值は中等 值である。

症例 : 61 (R)

閔值上年が特に著明な $1 \mathrm{KC}(35 \mathrm{~dB}) ， 2 \mathrm{KC}(30 \mathrm{~dB})$, $6 \mathrm{KC}(40 \mathrm{~dB})$ の noise audiogram は夫々第 1 の型, 2

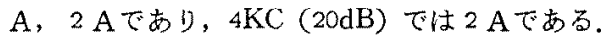

閝值上 $20 \mathrm{~dB}, 30 \mathrm{~dB}$ における DL 值は $1 \mathrm{KC}$ では夫 $0.8 \mathrm{~dB}, 0.6 \mathrm{~dB}$ で, $4 \mathrm{KC}$ では夫ね $0.8 \mathrm{~dB}, 0.8 \mathrm{db}$ である. $4 \mathrm{KC}$ のoise audiogram は第 2 の型で DL 值は中等 值である。

症例：61(L)

閥值上年が特に著明な $1 \mathrm{KC}(25 \mathrm{~dB}) ， 2 \mathrm{KC}(20 \mathrm{~dB})$, $3 \mathrm{KC}(20 \mathrm{~dB}), 4 \mathrm{KC}(25 \mathrm{~dB}), 6 \mathrm{KC}(15 \mathrm{~dB}) \odot$ noise audiogram は何れも第 1 の型である。

䦪值上 $20 \mathrm{~dB}, 30 \mathrm{~dB}$ における DL 值は $1 \mathrm{KC}$ は夫ね $0.6 \mathrm{~dB}, 0.6 \mathrm{~dB}$ で, $4 \mathrm{KC}$ で夫夫 $0.8 \mathrm{db}, 0.6 \mathrm{db}$ である.

$4 \mathrm{KC}$ の noise audiogram は第 1 の型で $\mathrm{DL}$ 值は中等 值である。

症例：62（R）

閶值上昇が特に著明な $8 \mathrm{KC}(60 \mathrm{~dB})$ の noise audiogramは $2 \mathrm{C} て ゙ あ り ， 4 \mathrm{KC}(30 \mathrm{~dB})$ では第1 の型である.

闇值上 $20 \mathrm{~dB}, 30 \mathrm{~dB}$ における DL 值は $1 \mathrm{KC}$ ば夫々 $1.0 \mathrm{~dB}, 0.8 \mathrm{~dB}$ で， $4 \mathrm{KC}$ では夫々 $0.8 \mathrm{~dB}, 0.8 \mathrm{~dB}$ である. $4 \mathrm{KC} の$ noise andiogram は第 1 の型で DL 值は中等 
值である.

症例：62(L)

閶値上笔が特に著明な $8 \mathrm{KC}(60 \mathrm{~dB})$ の noise audiogram は 2 Bであり， $4 \mathrm{KC}(35 \mathrm{db})$ では第 1 の型である.

間值上 $20 \mathrm{~dB}, 30 \mathrm{~dB}$ に扔ける $\mathrm{DL}$ 值は $1 \mathrm{KC}$ では夫々 $1.6 \mathrm{~dB}, 0.8 \mathrm{~dB}$ で, $4 \mathrm{KC}$ では夫々 $0.8 \mathrm{~dB}, 0.8 \mathrm{~dB}$ である. $4 \mathrm{KC} の$ noise audiogram は第 1 の型で DL 值は中等 值である。

症例：63（R)

閾值上㫒が特に著明な $2 \mathrm{KC}(65 \mathrm{~dB}), 4 \mathrm{KC}(60 \mathrm{~dB})$ ， $6 \mathrm{KC}(70 \mathrm{~dB}), 8 \mathrm{KC}(80 \mathrm{~dB}$ 以上) の noise audiogram

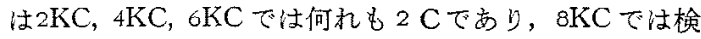
查不能である。

䦨值上 $20 \mathrm{~dB}, 30 \mathrm{~dB}$ 亿扔ける DL 值は $1 \mathrm{KC}$ では夫夕 $1.0 \mathrm{~dB}, 0.6 \mathrm{~dB}$ で, $4 \mathrm{KC}$ では夫々 $0.6 \mathrm{~dB}, 0.4 \mathrm{~dB}$ である. $4 \mathrm{KC} \sigma$ noise audiogram は第 $2 \sigma$ 型で DL 值は中等 值である。

症例：64（R)

䦨值上昇が特に著明な $8 \mathrm{KC}(65 \mathrm{~dB})$ の noise audiogram 悌 1 の型であり，4KC (40dB) でも第1の型で ある。

閵值上 $20 \mathrm{~dB}, 30 \mathrm{~dB}$ に㧍ける DL 值は $1 \mathrm{KC}$ で仗夫ヶ 1. $4 \mathrm{~dB}, 1.0 \mathrm{~dB}$ で， $4 \mathrm{KC}$ では夫々 $0.6 \mathrm{~dB}, 0.8 \mathrm{~dB}$ である. $4 \mathrm{KC} の$ noise audiogram は第 1 の型で DL 值は中等 值である。

症例：64(L)

閔值上昇が特に著明な $8 \mathrm{KC}(75 \mathrm{~dB})$ の noise audiogram は第1の型であり，4KC (55dB) でも第1の型で ある。

閥值上 $20 \mathrm{~dB}, 30 \mathrm{~dB}$ に扮ける DL 值は $1 \mathrm{KC}$ ではぬ $0.6 \mathrm{~dB}, 0.8 \mathrm{~dB}$ で， $4 \mathrm{KC}$ では夫々 $0.8 \mathrm{~dB}, 0.8 \mathrm{~dB}$ である. $4 \mathrm{KC} の$ noise audiogram は第 1 の型で DL 值性中等 值である、

\section{症例：65（R)}

闒值上昇が特に著明な $4 \mathrm{KC}(50 \mathrm{~dB}) ， 6 \mathrm{KC}(4 \mathrm{OdB})$ の noise audiogram は夫々 $2 \mathrm{~A}$, 第1の型である.

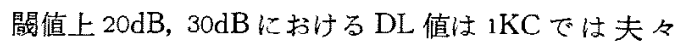
1. $2 \mathrm{~dB}, 1.0 \mathrm{~dB}$ で， $4 \mathrm{KC}$ では夫々0.8dB，0.8dB である.

$4 \mathrm{KC}$ の noise audiogram は第 2 の型で DL 值は中等 值である。

症例：65(L)

闌值上昇が特に著明な $3 \mathrm{KC}(45 \mathrm{~dB}), 4 \mathrm{KC}(50 \mathrm{~dB})$ の noise andiogram は夫々 $2 \mathrm{~A}, 2 \mathrm{~B}$ である。
閔値上 $20 \mathrm{~dB}, 30 \mathrm{~dB}$ における $\mathrm{DL}$ 值は $1 \mathrm{KC}$ な゙夫々 1. $2 \mathrm{~dB}, 0.8 \mathrm{~dB}$ で， $4 \mathrm{KC}$ では夫々0. $8 \mathrm{~dB}, 0.8 \mathrm{~dB}$ である. $4 \mathrm{KC} の$ noise audiogram 江第 2 の型で DL 值は中等 值である。

\section{症例：66(R)}

闎值上昇が特に著明な $6 \mathrm{KC}(60 \mathrm{~dB}), 8 \mathrm{KC}(70 \mathrm{~dB})$ の noise audiogram は $6 \mathrm{KC}$ では $2 \mathrm{E}, 8 \mathrm{KC}$ では検查不能 で， $4 \mathrm{KC}(55 \mathrm{~dB})$ では $2 \mathrm{~A}+2 \mathrm{E} ゙$ ある。

闒值上 $20 \mathrm{~dB}, 30 \mathrm{~dB}$ に括ける $\mathrm{DL}$ 值は $1 \mathrm{KC}$ では夫々 0. $8 \mathrm{~dB}, 0.6 \mathrm{~dB}$ で， $4 \mathrm{KC}$ では夫々0.4dB，0.4dB である. $4 \mathrm{KC} の$ noise audiogram は第 2 の型で DL 值は小で ある。

\section{症例：66（L)}

䦙值上昇が特に著明な $2 \mathrm{KC}(55 \mathrm{~dB}), 3 \mathrm{KC}(60 \mathrm{~dB})$, $4 \mathrm{KC}(65 \mathrm{~dB}), 6 \mathrm{KC}(60 \mathrm{~dB})$ 及び $8 \mathrm{KC}(80 \mathrm{~dB}$ 以上) の noise audiogram は夫々 $2 \mathrm{~B}, 2 \mathrm{~A}, 2 \mathrm{~A}+2 \mathrm{E}, 2 \mathrm{C}$ $2 \mathrm{D}$ で，8KC では検查不能である。

間值上 $20 \mathrm{~dB}, 30 \mathrm{~dB}$ に扝ける $\mathrm{DL}$ 值は $1 \mathrm{KC}$ では夫々

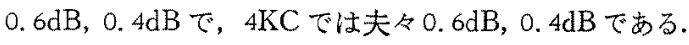
$4 \mathrm{KC} の$ noise audiogram は第 2 の型で DL 值は中等 值である。

症例： $67(\mathrm{R})$

䦪值上昇が特に著明な $1 \mathrm{KC}(30 \mathrm{~dB}) ， 4 \mathrm{KC}(30 \mathrm{~dB})$ ， $6 \mathrm{KC}(40 \mathrm{~dB}) の$ noise andiogram は何れも第 1 の型で ある.

闇值上 $20 \mathrm{~dB}, 30 \mathrm{~dB}$ に打ける $\mathrm{DL}$ 值は $1 \mathrm{KC}$ ではタ $0.8 \mathrm{~dB}, 0.8 \mathrm{~dB}$ で， $4 \mathrm{KC}$ では夫々0. $6 \mathrm{~dB}, 0.4 \mathrm{~dB}$ である. $4 \mathrm{KC} の$ noise audiogram は第 1 の型で DL 值は中等 值である。

症例：67（L)

閥值上杽が特に著明な $2 \mathrm{KC}(30 \mathrm{~dB}), 3 \mathrm{KC}(30 \mathrm{~dB})$ ， $4 \mathrm{KC}(45 \mathrm{~dB}), \quad 6 \mathrm{KC}(40 \mathrm{~dB}), 8 \mathrm{KC}(45 \mathrm{~dB})$ の noise audiogram は何れも第1の型である.

閔值上 $20 \mathrm{~dB}, 30 \mathrm{~dB}$ に打ける $\mathrm{DL}$ 值は $1 \mathrm{KC}$ では夫 $0.6 \mathrm{~dB}, 0.4 \mathrm{~dB}$ で， $4 \mathrm{KC}$ では夫々 $0.6 \mathrm{~dB}, 0.4 \mathrm{~dB}$ である. $4 \mathrm{KC} の$ noise audiogram 注第 1 の型で DL 值は中等 值である。

症例 : $68(\mathrm{~L})$

闒値上昇が特に著明な $6 \mathrm{KC}(45 \mathrm{~dB}), 8 \mathrm{KC}(55 \mathrm{~dB})$ の noise andiogram 法何れも第 1 の型であり，4KC（40 $\mathrm{dB}$ ) でも第1の型である.

闒值上 $20 \mathrm{~dB}, 30 \mathrm{~dB}$ に捛ける DL 值は $1 \mathrm{KC}$ では夫 $0.6 \mathrm{~dB}, 0.8 \mathrm{~dB}$ で， $4 \mathrm{KC}$ では夫々 $0.6 \mathrm{~dB}, 0.4 \mathrm{~dB}$ である. 
$4 \mathrm{KC}$ の noise audiogram 注第 1 の型で DL 值忙中等 值である。

定例 : $69(\mathrm{R})$

闇值上界が特に著明な $8 \mathrm{KC}(30 \mathrm{~dB})$ の noise audiogram は $2 \mathrm{E} て ゙ あ り ， 4 \mathrm{KC}(\mathrm{OdB})$ では第 1 の型である.

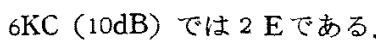

闘值上 $20 \mathrm{~dB}, 30 \mathrm{~dB}$ における $\mathrm{DL}$ 值は $1 \mathrm{KC}$ では夫 1. $4 \mathrm{~dB}, 1 . \mathrm{OdB}$ で, $4 \mathrm{KC}$ では夫々 1. $2 \mathrm{~dB}, 1.2 \mathrm{~dB}$ である.

$4 \mathrm{KC} の$ noise audingram は第 1 の型で DL 值は中等 値である。

症例 : $69(\mathrm{~L})$

闘值上舁が特に著明な $8 \mathrm{KC}$ ( $45 \mathrm{~dB})$ の noise audiodgram は $2 \mathrm{C}$ であり, $4 \mathrm{KC}(5 \mathrm{~dB})$ では第 1 の型であ ろ.

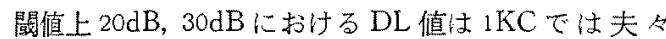
1. $2 \mathrm{~dB}, 1.0 \mathrm{~dB}$ で， $4 \mathrm{KC}$ では夫々 $0.6 \mathrm{~dB}, 0.4 \mathrm{~dB}$ である. $4 \mathrm{KC} の$ noise audiogram は第 1 の型で DL 值は中等 值である。

症例 : $70(\mathrm{R})$

閾值上昇が特に著明な $6 \mathrm{KC}$ ( $50 \mathrm{~dB}$ ) の noise andio-

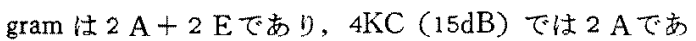
る.

閥值上 $20 \mathrm{~dB}, 30 \mathrm{~dB}$ 亿抾ける $\mathrm{DL}$ 值は $1 \mathrm{KC}$ では夫尔 1. $2 \mathrm{~dB}, 1.2 \mathrm{~dB}$ で, $4 \mathrm{KC}$ では夫々0.8dB，0.8dBである.

$4 \mathrm{KC}$ の noise audiogram は第 2 の型で DL 值は中等 值である.

症例：70（L)

閾值上昇が特に著明な $4 \mathrm{KC}(40 \mathrm{~dB}), 6 \mathrm{KC}(40 \mathrm{db})$, $8 \mathrm{KC}(45 \mathrm{db})$ の noise audiogram は夫々 $2 \mathrm{~A}, 2 \mathrm{~A}$, 第 1 の型である.

闒值上 $20 \mathrm{~dB}, 30 \mathrm{~dB}$ における $\mathrm{DL}$ 值は $1 \mathrm{KC}$ では夫

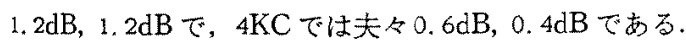
$4 \mathrm{KC}$ の noise audiogram は第 2 の型で DL 值は中等 值である。

症例: $71(\mathrm{R})$

閖值上昇が特に著明な $1 \mathrm{KC}(50 \mathrm{~dB}) ， 4 \mathrm{KC}(55 \mathrm{~dB})$ ， $6 \mathrm{KC}(60 \mathrm{~dB}), 8 \mathrm{KC}(55 \mathrm{~dB})$ の noise audiogram は夫 々第1の型， $2 \mathrm{E} ， 2 \mathrm{~A} ， 2 \mathrm{~B}$ である。

閥值上 $20 \mathrm{~dB}, 30 \mathrm{~dB}$ における $\mathrm{DL}$ 值は $1 \mathrm{KC}$ でま々 $0.6 \mathrm{~dB}, 0.8 \mathrm{~dB}$ で， $4 \mathrm{KC}$ では夫々0.6dB，0.6dBである. $4 \mathrm{KC}$ の noise andiogram は第 2 の型で DL 值は中等 値である。

定例 : $71(\mathrm{~L})$
闘值上昇が特に著明な $3 \mathrm{KC}(40 \mathrm{~dB}), 4 \mathrm{KC}(40 \mathrm{~dB})$, $6 \mathrm{KC}(40 \mathrm{~dB}), 8 \mathrm{KC}(35 \mathrm{~dB}) の$ noise andiogram 江何 れも第 1 の型である。

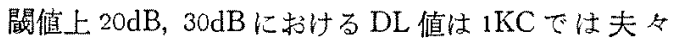
$0.8 \mathrm{~dB}, 0.8 \mathrm{~dB}$ で， $4 \mathrm{KC}$ では夫々 $0.8 \mathrm{~dB}, 0.8 \mathrm{~dB}$ である.

$4 \mathrm{KC}$ の noise audiogram 注第 1 の型で DL 值は中等 值である。

症例: $72(\mathrm{R})$

閾值上界が特に著明な $3 \mathrm{KC}(25 \mathrm{~dB}), 4 \mathrm{KC}(20 \mathrm{~dB})$ ， $8 \mathrm{KC}(30 \mathrm{~dB})$ の noise audiogram は何れも第 1 の型て ある。

閾值上 $20 \mathrm{~dB}, 30 \mathrm{~dB}$ に㧍りる DL 值は $1 \mathrm{KC}$ では夫 $1.0 \mathrm{~dB}, 0.8 \mathrm{~dB}$ で， $4 \mathrm{KC}$ では夫ヶ0.8dB，0.6dB である. $4 \mathrm{KC} の$ noise audiogram は第 19 型で DL 值は中等 値である。

症例 : 72(L)

闒值上吕が特に著明な $4 \mathrm{KC}(30 \mathrm{~dB}), 6 \mathrm{KC}(30 \mathrm{~dB})$, $8 \mathrm{KC}(40 \mathrm{~dB}) の$ noise audiogram は夫々第 $1 の$ 型, 2 A, 2 Bである.

闒值上 $20 \mathrm{~dB}, 30 \mathrm{~dB}$ における DL 值仕 $1 \mathrm{KC}$ では夫々 $1.0 \mathrm{~dB}, 0.8 \mathrm{~dB}$ で， $4 \mathrm{KC}$ では夫々 $1.2 \mathrm{~dB}, 1.0 \mathrm{~dB}$ である. $4 \mathrm{KC}$ の noise audioram 注第 1 の型で DL 值は中等 值である。

症例: $73(\mathrm{R})$

閶值上昇が特に著明な $8 \mathrm{KC}(40 \mathrm{~dB})$ の noise audiogram は $2 \mathrm{~B} て ゙ あ り ， 4 \mathrm{KC}(20 \mathrm{~dB})$ では第 1 の型であ る.

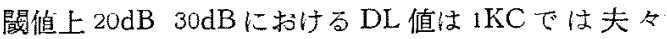
$1.6 \mathrm{~dB}, 1.4 \mathrm{~dB}$ で，4KC では夫々 $1.2 \mathrm{~dB} ， 1.2 \mathrm{~dB}$ である. $4 \mathrm{KC} の$ noise audiogram は第 1 の型で DL 值は中等 值である。

症例: $23(\mathrm{~L})$

闇值上昇が特に著明な $8 \mathrm{KC}(35 \mathrm{~dB})$ の noise audiogram は $2 \mathrm{~B} て ゙ あ り, ~ 4 \mathrm{KC}(15 \mathrm{~dB})$ では第10型であ る:

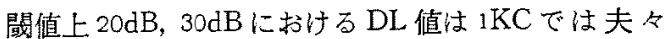
1. $\mathrm{OdB}, 1.0 \mathrm{~dB}$ で, $4 \mathrm{KC}$ では夫々 $1.0 \mathrm{~dB}, 0.6 \mathrm{~dB}$ である. $4 \mathrm{KC} の$ noise audiogram 政 1 の型で DL 值は中等 値である.

症例: $74(\mathrm{R})$

䦪值上昇が特化著明な $4 \mathrm{KC}(45 \mathrm{~dB}), 6 \mathrm{KC}(45 \mathrm{~dB})$ の noise audiogram 洼夫々 $2 \mathrm{~B}$ ，第 1 の型である。

閔值上 $20 \mathrm{~dB}, 30 \mathrm{~dB}$ に扝ける $\mathrm{DL}$ 值は $1 \mathrm{KC}$ では夫々 
1. $2 \mathrm{~dB}, 0.8 \mathrm{~dB}$ で, $4 \mathrm{KC}$ では夫々0.6dB, $0.4 \mathrm{~dB}$ である. $4 \mathrm{KC} の$ noise audiogram は第 2 の型で DL 值住 值である。

\section{症例 : 74 (L)}

䦗值上昇が特に著明な $3 \mathrm{KC}(30 \mathrm{~dB}) ， 4 \mathrm{KC}(40 \mathrm{~dB})$, $6 \mathrm{KC}(40 \mathrm{~dB}), 8 \mathrm{KC}(35 \mathrm{db})$ D noise audiogram なは $2 \mathrm{E} ， 4 \mathrm{KC}, 6 \mathrm{KC}, 8 \mathrm{KC}$ では何孔も2 $\mathrm{B}$ である。

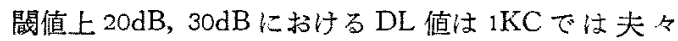
1. $2 \mathrm{~dB}, 0.8 \mathrm{~dB}$ で, $4 \mathrm{KC}$ でまね $0.4 \mathrm{~dB}, 04 \mathrm{~dB}$ である.

$4 \mathrm{KC} の$ noise audiogram は第 2 の型で DL 值は小で ある。

\section{正例: 75 ( $\mathrm{R}$ )}

䦪值上早が特に著明な $2 \mathrm{KC}(20 \mathrm{~dB}) ， 3 \mathrm{KC}(20 \mathrm{~dB})$, $4 \mathrm{KC}(20 \mathrm{~dB}), 6 \mathrm{KC}(30 \mathrm{~dB}), 8 \mathrm{KC}(30 \mathrm{db})$ の noise audiogram $2 \mathrm{KC}, 3 \mathrm{KC}, 4 \mathrm{KC}$ では何狄も第 1 の型であ

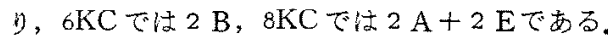

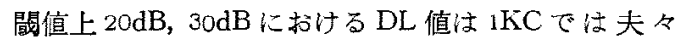
1. $8 \mathrm{~dB}, 1.8 \mathrm{~dB}$ で, $4 \mathrm{KC}$ でまね $1.4 \mathrm{~dB}, 1 . \mathrm{OdB}$ である.

$4 \mathrm{KC} の$ noise audiogram 第 1 の型で DL 值は中等 值である。

\section{症例: $75(\mathrm{~L})$}

閵值上昇が特に著明な $6 \mathrm{KC}(25 \mathrm{~dB}) ， 8 \mathrm{KC}(30 \mathrm{~dB})$ の noise audiogram は夫々 $2 \mathrm{~A}, 2 \mathrm{~B}$ であり, $4 \mathrm{KC}(10$ dB) では第 1 の型である.

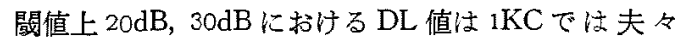

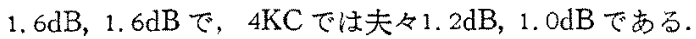
$4 \mathrm{KC} の$ noise audiogram は第 1 の型で DL 值は中等 値である。

症例 : 76 (L)

䦪值上昇唯特に著明な $4 \mathrm{KC}(30 \mathrm{~dB}) ， 6 \mathrm{KC}(25 \mathrm{~dB})$ ， $8 \mathrm{KC}(25 \mathrm{~dB})$ の noise audiogram $は$ 去 $2 \mathrm{~B}, 2 \mathrm{~B}$, 2 Cである。

閥值上 $20 \mathrm{db}, 30 \mathrm{db}$ に括ける DL 值は $1 \mathrm{KC}$ は夫々 1. $6 \mathrm{~dB}, 1.6 \mathrm{~dB}$ で, $4 \mathrm{KC}$ では夫々0. $4 \mathrm{~dB}, 0.4 \mathrm{~dB}$ である. $4 \mathrm{KC} の$ noise audiogram 法第 2 の型で DL 值は小で 㐫。

\section{症例: 77 (R)}

閾值上算が 特に著明な $8 \mathrm{KC}(70 \mathrm{~dB})$ の noise audio-

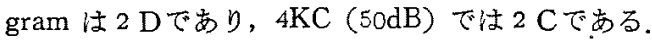

間值上 $20 \mathrm{~dB}, 30 \mathrm{~dB}$ に拈ける DL 值は $1 \mathrm{KC}$ では夫 1. $\mathrm{OdB}, 1 . \mathrm{OdB}$ で, $4 \mathrm{KC}$ では夫々 $1.4 \mathrm{~dB}, 1.2 \mathrm{~dB}$ である. $4 \mathrm{KC} の$ noise audiogram は第 2 の型で DL 值は中等 值である。
症例: 77 (L)

閖值上昇が特に著明な $6 \mathrm{KC}(70 \mathrm{~dB}) ， 8 \mathrm{KC}(80 \mathrm{~dB})$ の noise audiogram は何れも $2 \mathrm{D}$ であり, $4 \mathrm{KC}(65 \mathrm{~dB})$ で 壮2 Bである。

閶值上 $20 \mathrm{~dB}, 30 \mathrm{~dB}$ における $\mathrm{DL}$ 值は $1 \mathrm{KC}$ な゙ま々 $1.0 \mathrm{~dB}, 1 . \mathrm{OdB}$ で， $4 \mathrm{KC}$ では闇值上 $20 \mathrm{~dB}$ では1.0dB，閶 値上30dBで惊查不能である。

$4 \mathrm{KC}$ の noise audiogram は第 2 の型で DL 值は中等 值である。

症例: $78(\mathrm{R})$

閶值上昇が特に著明な $3 \mathrm{KC}(60 \mathrm{~dB}) ， 4 \mathrm{KC}(70 \mathrm{~dB})$, $6 \mathrm{KC}(70 \mathrm{~dB}), 8 \mathrm{KC}(70 \mathrm{~dB})$ の noise audiogram では $2 \mathrm{C}, 4 \mathrm{KC}, 6 \mathrm{KC}$ では White noise $10 \mathrm{~dB}$ から60dB の強さまで，全く閖值の変化はない，8KCでは $2 \mathrm{Cであ}$ 万.

闖值上 $20 \mathrm{~dB}, 30 \mathrm{~dB}$ における DL 值は1KCでは夫々 1. $2 \mathrm{~dB}, 1 . \mathrm{OdB}$ で， $4 \mathrm{KC}$ では夫々検查不能である。 $4 \mathrm{KC} の$ noise audiogram は第 2 の型で DL 值は検查 不能である。

症例: $78(\mathrm{~L})$

間值上昇が特に著明な $6 \mathrm{KC}(75 \mathrm{~dB}) ， 8 \mathrm{KC}(80 \mathrm{~dB})$ の noise audiogram は夫々 $2 \mathrm{D}, 2 \mathrm{~A}$ であり, $4 \mathrm{KC}(50$ dB) では 2 Aである。

關值上 $20 \mathrm{~dB}, 30 \mathrm{~dB}$ における DL 值は1KCでは夫々 $0.8 \mathrm{~dB}, 0.8 \mathrm{~dB}$ で, $4 \mathrm{KC}$ では夫々0.8dB, 0. $6 \mathrm{~dB}$ である. $4 \mathrm{KC}$ の noise audiogram は第 2 の型で DL 值は中等 值である。

症例 : $79(\mathrm{R})$

闒值上昇が特に著时な $8 \mathrm{KC}(55 \mathrm{~dB})$ の noise audiogram は $2 \mathrm{D}$ であり, $4 \mathrm{KC}(5 \mathrm{~dB})$ では $2 \mathrm{Eである.}$

闒值上 $20 \mathrm{~dB}, 30 \mathrm{~dB}$ における $\mathrm{DL}$ 值は $1 \mathrm{KC}$ で夫々 $1.0 \mathrm{~dB}, 0.8 \mathrm{~dB}$ で, $4 \mathrm{KC}$ では夫々 $1.0 \mathrm{~dB}, 0.6 \mathrm{~dB}$ である. $4 \mathrm{KC}$ は noise audiogram は第 2 の型で $\mathrm{DL}$ 值は中等 值である。

症例 : $79(\mathrm{~L})$

閾值上昇が特に著明な $8 \mathrm{KC}(70 \mathrm{~dB})$ の noise audiogram は $2 \mathrm{~B}+2 \mathrm{E}$ であり, $4 \mathrm{KC}(50 \mathrm{~dB})$ では $2 \mathrm{~A}+$ $2 \mathrm{E}$ である。

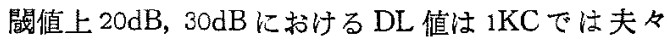
$1.0 \mathrm{~dB}, 0.8 \mathrm{~dB}$ で，4KC では夫々0.6dB，0.6dBである. $4 \mathrm{KC}$ の noise audiogram は第 2 の型で $\mathrm{DL}$ 值は中等 值である。

症例: $80(\mathrm{R})$ 
閶值上界が特に著明な $4 \mathrm{KC}(40 \mathrm{~dB}) ， 6 \mathrm{KC}(50 \mathrm{~dB})$, $8 \mathrm{KC}(45 \mathrm{~dB})$ の noise audiogram は夫々 $2 \mathrm{E}, 2 \mathrm{~B}$, 2 Eである.

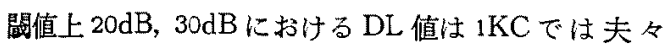
$0.4 \mathrm{~dB}, 0.2 \mathrm{~dB}$ で, $4 \mathrm{KC}$ では夫々 $0.4 \mathrm{~dB}, 0.4 \mathrm{~dB}$ である.

$4 \mathrm{KC}$ の noise audiogram は第 2 の型で DL 值は小で ある。

\section{症例 : $80(\mathrm{~L})$}

闇值上昇が特に著明な $6 \mathrm{KC}(60 \mathrm{~dB})$ の noise audio-

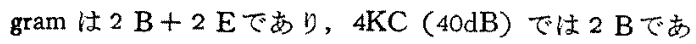
了.

闒值上 $20 \mathrm{~dB}, 30 \mathrm{~dB}$ における DL 值は $1 \mathrm{KC}$ では夫ヶ $0.4 \mathrm{~dB}, 0.4 \mathrm{~dB}$ で， $4 \mathrm{KC}$ では夫

$4 \mathrm{KC} の$ noise audiogram は第 2 の型で DL 值は小で ある.

症例 : $81(R)$

闘值上昇が 特に著明な $8 \mathrm{KC}(65 \mathrm{~dB})$ の noise audiogram は White noise $10 \mathrm{~dB}$ から 50dB の強さまで闌值

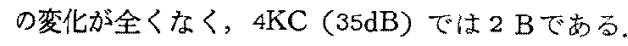

闎值上 $20 \mathrm{~dB}, 30 \mathrm{~dB}$ における DL 值は $1 \mathrm{KC}$ では夫ヶ $0.8 \mathrm{~dB}, 0.8 \mathrm{~dB}$ で， $4 \mathrm{KC}$ では夫々 $0.6 \mathrm{~dB}, 0.6 \mathrm{~dB}$ である. $4 \mathrm{KC} の$ noise audiogram 壮第 2 の型で DL 值は中等 值である。

症例: $82(\mathrm{R})$

䦥值上昇が特に著明な $6 \mathrm{KC}(60 \mathrm{~dB}), 8 \mathrm{KC}(65 \mathrm{~dB})$ の noise audiogram は $6 \mathrm{KC}$ では $2 \mathrm{D}, 8 \mathrm{KC}$ では White noise $10 \mathrm{~dB}$ から50dBの強さまで閶值の変化が全くなく, $4 \mathrm{KC}(50 \mathrm{~dB})$ では 2 Bである.

闘值上 $20 \mathrm{~dB}, 30 \mathrm{db}$ における DL 値は $1 \mathrm{KC}$ では夫多 $0.6 \mathrm{~dB}, 0.6 \mathrm{~dB}$ で, $4 \mathrm{KC}$ では夫々 $0.6 \mathrm{~dB}, 0.6 \mathrm{~dB}$ である.

$4 \mathrm{KC} の$ noise audiogram は第 2 の型で $\mathrm{DL}$ 值は中等 値である。

症例: $82(\mathrm{~L})$

閶值上昇が特汇著明な $4 \mathrm{KC}(55 \mathrm{~dB}), 6 \mathrm{KC}(60 \mathrm{~dB})$, $8 \mathrm{KC}(65 \mathrm{~dB})$ の noise audiogram は夫々 $2 \mathrm{C}, 2 \mathrm{D}$, 2 Dである.

關值上 $20 \mathrm{~dB}, 30 \mathrm{~dB}$ に扔ける DL 值は $1 \mathrm{KC}$ で夫 $0.6 \mathrm{~dB}, 0.6 \mathrm{~dB}$ で， $4 \mathrm{KC}$ では夫々 $0.4 \mathrm{~dB}, 0.4 \mathrm{~dB}$ である. $4 \mathrm{KC}$ の noise audiogram は第 2 の型で DL 值は小で ある。

正例 : $83(\mathrm{~L})$

闒值上后が特に著明な $4 \mathrm{KC}(45 \mathrm{~dB}), 6 \mathrm{KC}(45 \mathrm{~dB})$, $8 \mathrm{KC}(35 \mathrm{~dB})$ の noise audiogram は夫々 $2 \mathrm{~B}, 2 \mathrm{C}$,
2 Bである.

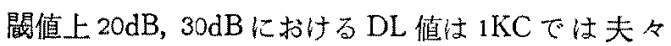
1. $4 \mathrm{~dB}, 1.2 \mathrm{~dB}$ で, $4 \mathrm{KC}$ では夫々 $1.0 \mathrm{~dB}, 0.8 \mathrm{~dB}$ である. $4 \mathrm{KC} \sigma$ noise audiogram は第 2 の型で DL 值は中等 值である。

症例：84(R)

䦭值上昇が特に著明な $6 \mathrm{KC}(40 \mathrm{~dB}), 8 \mathrm{KC}(35 \mathrm{~dB})$ の noise audiogram住何れも $2 \mathrm{C}$ であり, $4 \mathrm{KC}(20 \mathrm{~dB})$ で は第 1 の型である.

䦭值上 $20 \mathrm{~dB}, 30 \mathrm{~dB}$ に㧍ける $\mathrm{DL}$ 值は $1 \mathrm{KC}$ では夫々

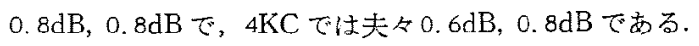
$4 \mathrm{KC}$ の noise audiogram は第 1 の型で $\mathrm{DL}$ 值は中等 值である。

症例 : $84(\mathrm{~L})$

間值上昇が特に著明な $4 \mathrm{KC}(25 \mathrm{~dB}), 6 \mathrm{KC}(30 \mathrm{~dB})$, $8 \mathrm{KC}(35 \mathrm{~dB})$ の noise audiogram 注夫々 $2 \mathrm{~A}, 2 \mathrm{~A}+$ $2 \mathrm{E} ２ \mathrm{D}$ である.

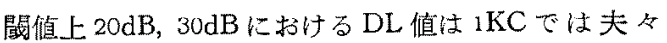
1. $4 \mathrm{~dB}, 1.2 \mathrm{~dB}$ で， $4 \mathrm{KC}$ では夫々 $0.8 \mathrm{~dB}, 0.8 \mathrm{~dB}$ である. $4 \mathrm{KC}$ の noise audiogram は第 2 の型で DL 值は中等 值である。

症例 : $85(\mathrm{R})$

間值上昇が特に著明な $6 \mathrm{KC}(75 \mathrm{~dB}), 8 \mathrm{KC}(75 \mathrm{~dB})$ の noise audiogram は何九も White noise $10 \mathrm{~dB}$ 加 $60 \mathrm{~dB}$ の強さまで閵值の変化は全くなく，4KC $(55 \mathrm{~dB})$ では $2 \mathrm{D}$ である。

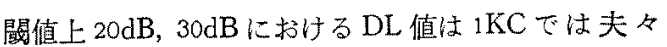
$1.2 \mathrm{~dB}, 0.8 \mathrm{~dB}$ で， $4 \mathrm{KC}$ では夫々 $0.6 \mathrm{~dB} ， 0.4 \mathrm{~dB}$ である. $4 \mathrm{KC}$ の noise audiogram は第 2 の型で $\mathrm{DL}$ 值は中等 值である.

症例 : $85(\mathrm{~L})$

閶值上昇が特に著明な $6 \mathrm{KC}(40 \mathrm{~dB})$ の noise audio-

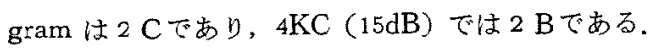

$3 \mathrm{KC}(10 \mathrm{~dB})$ では $2 \mathrm{~A}$ である.

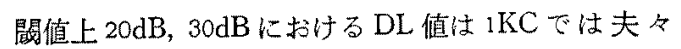
$0.6 \mathrm{~dB}, 0.6 \mathrm{~dB}$ で, $4 \mathrm{KC}$ では夫々0. $6 \mathrm{~dB}, 0.6 \mathrm{~dB}$ である. $4 \mathrm{KC}$ の noise augiogram は第 2 の型で DL 值は中等 值である、

症例 : $86(\mathrm{R})$

留閶值上昇が特に著明な $4 \mathrm{KC}(40 \mathrm{~dB}), 6 \mathrm{KC}(40 \mathrm{~dB})$ の noise audiogram は夫々 $2 \mathrm{E}, 2 \mathrm{C}$ である。

$2 \mathrm{KC}(10 \mathrm{~dB}), 8 \mathrm{KC}(\mathrm{OdB})$ では何れも $2 \mathrm{~A}$ である.

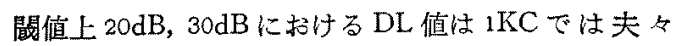


$0.6 \mathrm{~dB}, 0.6 \mathrm{~dB}$ で， $4 \mathrm{KC}$ では夫々0. $4 \mathrm{~dB}, 0.4 \mathrm{~dB}$ である。 $4 \mathrm{KC}$ の noise audiogram は第 2 の型で DL 值は小で ある。

症例：86(L)

閾值上昇が特に著明な $4 \mathrm{KC}(55 \mathrm{~dB}) ， 6 \mathrm{KC}(50 \mathrm{~dB})$

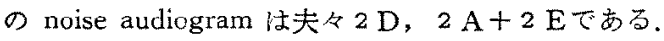

閖值上 $20 \mathrm{~dB}, 30 \mathrm{~dB}$ に㧍ける $\mathrm{DL}$ 值は $1 \mathrm{KC}$ でま々 $0.6 \mathrm{~dB}, 0.4 \mathrm{~dB}$ で, $4 \mathrm{KC}$ では夫々 $0.2 \mathrm{~dB}, 0.2 \mathrm{~dB}$ である. $4 \mathrm{KC} の$ noise audiogram 注第 2 の型で DL 值壮小で ある。

\section{症例 : 87（R)}

閾值上昇が特に著明な $4 \mathrm{KC}(50 \mathrm{~dB}) ， 6 \mathrm{KC}(50 \mathrm{~dB})$, $8 \mathrm{KC}(60 \mathrm{~dB})$ の noise audiogram は4KC, 6KC では何

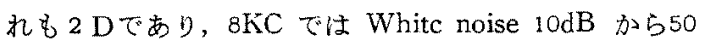
$\mathrm{dB}$ の强さまで閶值の変化は全くない.

閥值上 $20 \mathrm{~dB}, 30 \mathrm{~dB}$ に扔ける $\mathrm{DL}$ 值は $1 \mathrm{KC}$ では夫々 1. $2 \mathrm{~dB}, 1.2 \mathrm{~dB}$ で， $4 \mathrm{KC}$ で恃夫々 $0.4 \mathrm{~dB}, 0.4 \mathrm{~dB}$ である。 $4 \mathrm{KC} の$ noise auiogram は第 2 の型で DL 值は 小で ある。

\section{症例 : $87(\mathrm{~L})$}

閶值上昇が特に著明な $4 \mathrm{KC}(50 \mathrm{~dB}), 6 \mathrm{KC}(50 \mathrm{~dB})$ ， $8 \mathrm{KC}(6 \mathrm{~dB})$ の noise audiogram は 4KC では White noise $10 \mathrm{~dB}$ 加ら50dBの強さまで閾值の变化は全くなく, 6KC では $2 \mathrm{D} て ゙ あ り ， 8 \mathrm{KC}$ では White noise $10 \mathrm{~dB}$ か ら $60 \mathrm{~dB}$ の強さまで闇值の変化は全くない．

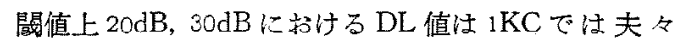
$1.6 \mathrm{~dB}, 1 . \mathrm{OdB}$ で, $4 \mathrm{KC}$ では夫々 $0.4 \mathrm{~dB}, 0.4 \mathrm{~dB}$ である. $4 \mathrm{KC} の$ noise audiogram は第 2 の型で DL 值は小で ある。

\section{小 括}

難㯖の原因を明らかにし得ない72耳の闇值上昇が特に 高度な周波数の noise audiogram仕，第1 の型だけ示す むのは16耳であり，第2の型だけ示すむのは43耳であり， 第1の型と第 2 の型鿖合併しているものは13耳である。

しかして4KCの noise audiogram は第 1 の型を示寸 ものは30耳であり，第2の型を示すものは42耳である.

次に $1 \mathrm{KC}, 4 \mathrm{KC}$ の閾値上 $20 \mathrm{~dB}, 30 \mathrm{~dB}$ に括ける DL 值 は次のようである。

$1 \mathrm{KC}$ では閶値上 $20 \mathrm{~dB}, 30 \mathrm{~dB} の \mathrm{DL}$ 值は夫々 $0.4 \mathrm{~dB}$, $0.2 \mathrm{~dB}$ から $1.8 \mathrm{~dB}, 1.8 \mathrm{~dB}$ の間にあり，多くは中等值の 範囲内にあるが，小のものも少数ある。

$4 \mathrm{KC}$ で闎值上 $20 \mathrm{~dB}, 30 \mathrm{~dB}$ の DL 值は夫々 $0.2 \mathrm{~dB}$, 0. $2 \mathrm{~dB}$ から 1. $4 \mathrm{~dB}, 1.4 \mathrm{~dB}$ の閒にあり，中等值の籁团内
にあるものは56耳，小のものは13耳である，検查不能の ものは 3 耳である。

しかして 4KCで第1の型のもの30耳の DL 值は中等 值のものは28耳, 小のものは 1 耳であり, 検查不能のも のは 1 耳である、第 2 の型のもの42耳の DL 值は小のも のは12耳であり，中等值のものは28耳であり，検查不能 のものは 2 耳である。

第 2 の型で DL 值が中等值のものの DL 值を仔細に検 討すると，16耳において中等值の内では小さい部類であ る. 5 耳においては $4 \mathrm{KC} の \mathrm{DL}$ 值は $1 \mathrm{KC} の \mathrm{DL}$ 值より 小である。 3 耳においては中等值である、1耳において は $4 \mathrm{KC}$ の純音閾值は正常であり，3耳においては $15 \mathrm{~dB}$ 又は20dBに過ぎない。

次汇純音闘值が正常籁围内にあつて，第 2 の型を示す $69(\mathrm{R})$ の $6 \mathrm{KC}, 79$ (R) の $4 \mathrm{KC}, 85$ (L) の $3 \mathrm{KC}, 86$ (R) の $2 \mathrm{KC}$ と $8 \mathrm{KC}$ がある.

\section{第 4 章 総括並びに考按}

以上の成績を総括するに，一般外来における感音難聴 耳151耳の，閾值上昇が特に高度な周波数における noise audiogram は. White noise の強さを増す每に闇值も変 化する第 1 の型を示すむのが 21 耳, White noise の強さ を增しても間值が変化しない第2 の型を示すものが 109 耳, そして第 1 の型と第 2 の型を合阱しているものが 21 耳であり，全般的には第 2 の型を示すむのが最も多く， その他の型を示すをの沙少小。

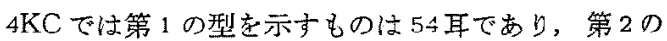
型を示寸ものは96耳である。他の1 耳は $4 \mathrm{KC}$ では検査 不能である。

しかして，4KCの noise audiogram が第1の型を示 す54耳では，DL 值が中等值のもの50耳であり，小のも のは 2 耳 $(34(\mathrm{~L}), 55(\mathrm{R}))$ である。他の2耳で注 DL 値は検查不能である。

4KCの noise audiogram が第2 の型を示す96耳では $\mathrm{DL}$ 值が小のものは 50 耳であり，中等值のものは 4 耳で 西る. 他の 2 耳では DL 値は検查不能である.

しかして，第 2 の型を示して DL 值が中等值のものの DL 值を仔䋖に検討すると，24耳（2（L)，19(R)，19 (L), 30(L), 32(L), 35(R), 39(R), $41(R), 48$ (L), 50(R), 53(R), $54(R), 54(\mathrm{~L}), 5$ ? (L), 63 (R), 66(L), $70(\mathrm{~L}), 71(\mathrm{R}), 74(\mathrm{R}), 78(\mathrm{~L}), 79$ (L)，81(R)，82(R)，85(R)）に招いて忙中等值の内 では小の部類である。 5 耳 $(56(R) ， 65(R) ， 65(L) ， 83(L) ， 84(L)) k$ 
おいては $4 \mathrm{KC}$ の $\mathrm{DL}$ 值は $1 \mathrm{KC} の \mathrm{DL}$ 值より小である。

$8 耳(16(\mathrm{~L}), 31(\mathrm{R}), 37(\mathrm{R}), 46(\mathrm{R}), 46(\mathrm{~L}), 57$ (R)，77(R)，77(L)) においては $4 \mathrm{KC} の \mathrm{DL}$ 值は中 等值である。

3 耳 $(69(\mathrm{R}) ， 69(\mathrm{~L}) ， 79(\mathrm{~L}))$ においては $4 \mathrm{KC}$ 純 音閶值は正常である。

4 耳 $(21(\mathrm{~L}) ， 61(\mathrm{R}) ， 20(\mathrm{R}) ， 85(\mathrm{~L}))$ においては $4 \mathrm{KC}$ 純音䦪值は15dB 又は $20 \mathrm{~dB}$ に過ぎない。

これらの結果から，第1の型を示すものでは内耳の病 变によるものではないと考えられる。

第2の型を示し，DL值が小のものでは Corti 氏器に 障害があると考えられる。

DL 值が中等值の内では小の部類のものと，1KCの DL 值より小のものでは，DL值の個人差を考慮したと しても，Corti 氏器に障害のあることを示唆するものと 考えられる。従つて、これらの例では noise audiometry の方がDL Tcstよりは一層明確に病変部位を示してく れるものではないかと考えられる。

次に第 1 型を示し DL 值が小のものと，第 2 の型で DL 值が中等值のものでは，これらの成績のみからは病 変部位の判別は難しい.

すなわち，第1 の型で DL 值が小のものでは Corti 氏 器の障害老全く否定することはできないし, noise audiogram は第1の型老しており, 促つて両者の成續から 考えられる病変部位は一致しない。

又, 第 2 の型を示し, DL 值が小の傾向を示さぬの では, noise audiogram のみからは Corti 氏器の障害が 考えられるが, DL 值が中等值であるので, Corti氏器に 障害があるとはいえない，従つて，Corti 氏器と后迷路 性の障害の合併ということも考えられるが，DL值が小 でない場合に，必ずしもCorti 氏器の障害を否定できな いことを考虑すると，この DL 值のみから后迷路性の障 害があるともいえない。

この事は，かかる検查法による病熊の把握が必ずしも 病変部位と直接関連していないことのあることを示㗜し ている.

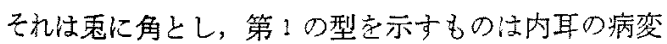
によるものでなく，第2の型を示すものは内耳の病変に よるものであるうと考えられることは，騷音性難聴及び 老人性難㯖の成績からも考えられるし，Langenbeck 研究成績とも一致するとこるである。

このこと加ら，第 1 の型々第 2 型加合併しているも のでは, 后迷路性の障害とCorti 氏器の障害价合併して
いるのではないかと考えられる。 この混合型の変化について, Langenbeck ${ }^{49}$ は, 老人性 難聴耳と外傷性難㯖耳について，内耳毛細胞と神経節細 胞の障害が其存している例妾報告して扔りこのような 症例では，或る音域では内耳毛細胞の障害が主役を演 じ，他の音域では神経節細胞の障害が主役を演ずると し,このような難聴を感音性混合難㯖としている。 $\mathrm{Palva}^{50}$ \&老人性難聴耳と外賃性難聴耳のある症例では 障害部位が内耳毛細胞と神経節細胞，あるいは内耳毛細 胞上种経線維とに混在する場合もあると述心て扔りこ れらは Corti 氏器と后迷路性の障害とが合侀している症 例のありうることを示しているもの上思われる。

次に noise audiogram は第 2 の型宗示ものにおい て，純音閶值が正常に近いものがある。

しかして第2 の型は Corti 氏器に障害のあることが考 えられる noise audiogram の型であり，純音閶值が正 常籁囲，ある以はその附近にあるにも拘らず，Corti 氏 器に障害のあることも考えなければならない，

それなら代何故䦚值が上昇しないかといらことである が，この状態は正常者のあるものにもみられた noise audiogramで岁つて，現在の段階では絉音閏值が上昇す る程の明らかな障害ではなく，White noise を負荷する ことにより始めて現われた潜在性の障害であると推察し Tいる

このことは $4(\mathrm{R}), 14(\mathrm{~L}) ， 23(\mathrm{R}), 69(\mathrm{R}), 79(\mathrm{R})$ においては闘值上昇が明らかな周波数に近い周波数にお いて認められたものであり，病変が，この周波数の部に も波及の可能性が充分考えられる状態にあり，これらの

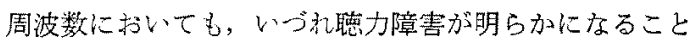
が疑われる。従つて現在は，その障害顕現の隻備状態に あるものと推考される。

\section{第 5 章 結 語}

第1篇で，閶值上昇が高い周波数に括いて，White noise による閾值の変化が, White noise の強さ增寸

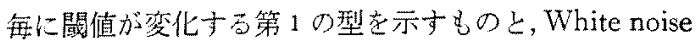
の強さを増しても閾值が変化しない第 2 の型を示すもの と，第1と第 2 型が合併しているものとに区別でき to.

これらの White noiseによる閶值の変化の型と障害部 位との関保汶，第1の型で位后迷路性の障害を，第 20

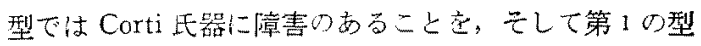
と第2の型が合併したものでは Corti 氏器と后迷路性の 障害が合併しているこもが推考さ机た。 
これを基準として，一般外来における感音難聴耳，す なわち騷音によると思利机るもの35耳，メニエル氏病に 上ると思われるもの9耳，老人性と思わ机るもの10耳， ストマイによると思われるもの11耳，頭部外傷によると 思われるもの14耳，原因が明らかでないもの72耳につい $\tau$, 本検查上 DL T cst を行い, 次の結果を得た。

1）騒音によると思われる難㯖耳では，第1の型だけ 示寸ものはなく，殆しどが第20型老示し，Corti 氏器の障害怔考えられ，第 1 の型上第 2 の型圭示す 1 耳では障害部位が Corti 氏器から后迷路へ進展し ているのではないかと思われる。

メニュル氏病によると思わ礼る難㯖耳では，全例 が第 2 の型を示し，Corti 氏器の障害を示している ものと思和る。

2) 老人性によると思われる難聴耳，ストマイによる と思われる難聴耳，頭部外傷によると思わ饥る難㯖 耳, 原因が明らかでない難聴耳では，第 1 の型だけ 示すもの，第 2 の型だけ示すもの，第 1 の型と第 2 の型が合併しているもの上があり，その障害部位は 一定していないと思わ机尚。

3) White noise による閔值の変化とDL 值との関係 については，閾值上20dB 上30dBに括ける DL 值を そのまま用い，0.4dB 以下の值を小と記したが，DL 值が小のものでは 1 耳を除いて第 2 の型を示してい る. DL 值が中等値を示寸ものでは，第 1 の型を示 すもの，第 2 の型を示すもの，第 1 の型と第 2 の型 が合併しているものとがある。

こ机らの関倸を White noiseによる間值の変化の 型からみると，第 1 の型を示すものでは 1 耳を除い てDL 值は中等值を示している，第2 の型を示すを のでは DL 值が小の值を示すもの上，中等值を示す ものとがある。

第 1 の型と第 2 の型が合併しているものでは 2 耳 を除いてDL 值は中等犆を示している。

4）次に閵值上昇が高い周波数附近の周波数において 純音閶值が正常籁团内にあっても，第 2 の型を示す ものがあるが，これは将来，その周波数に障害がお こる可能性を示唆する変化と思加れ，現在はその障 害顕現の隻備状態にあることが疑わ机る変化である 5) 以上の結果から本検查法によって，感音難聴耳の 障害部位の鑑別診断が，ある程度まで可能であり， 又，将来において聴力障害が顕われるであるらと思 われる潜在性の聴力異常を見出し得ることがある。

しかしここれらの秸果がすべての場合に適合する とは限らないのは当然であるが，一つの検查法とし て，臨床的に匛用する価值のあるるのと考光る。

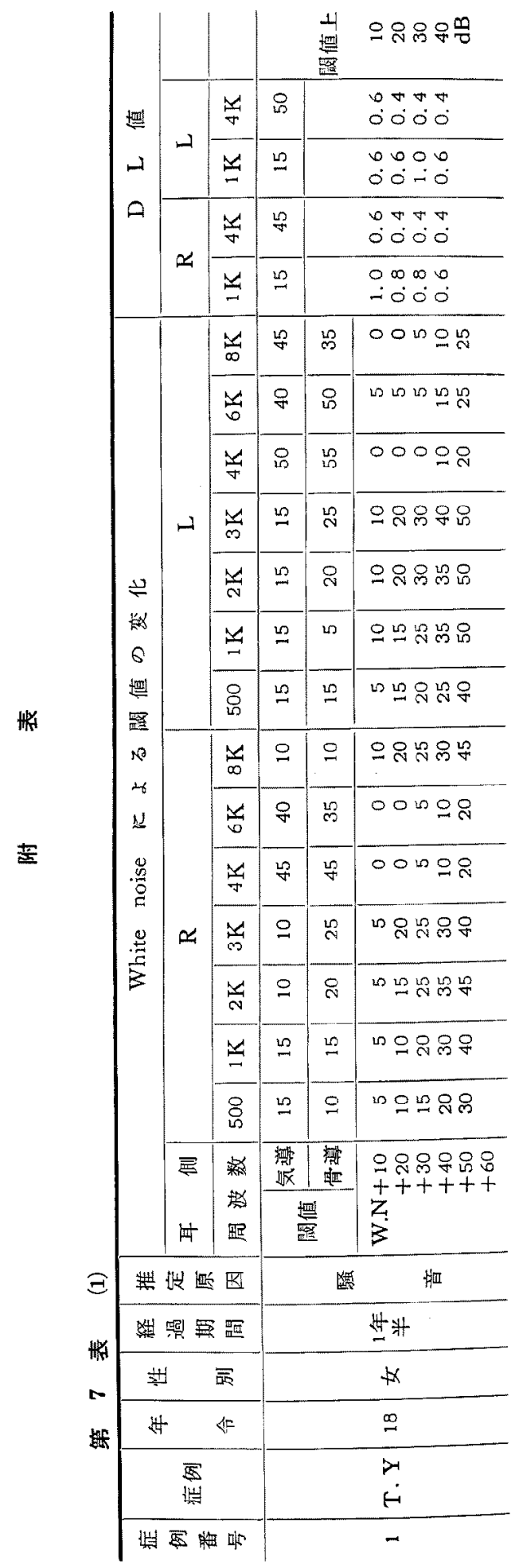




\begin{tabular}{|c|c|c|c|c|c|c|c|c|c|c|c|c|c|}
\hline & & & $\begin{array}{l}\text { 岑 } \\
\text { 澴 } \\
\text { 䔲 }\end{array}$ & 응용ㅇㅁㅁㅁㅁ & & 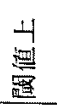 & 오용우국 & & 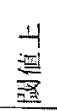 & 으오음우의 & & $\begin{array}{l}4 \\
\text { 彭 } \\
\text { 渭 }\end{array}$ & 응요윰ㅁㅁ \\
\hline \multirow{2}{*}{$\omega$} & $\stackrel{y}{y}$ & ஜ & & $\begin{array}{r}0000 \\
-1000 \\
-0.0 \\
\end{array}$ & $m$ & & 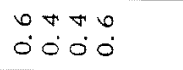 & $\stackrel{\infty}{+}$ & & $\begin{array}{lll}0 & \pi & \pi \\
0 & 0 & 0 \\
0 & 0\end{array}$ & 용 & & $\begin{array}{l}0 \pi \nabla \\
0000\end{array}$ \\
\hline & $\ddot{z}$ & $\stackrel{2}{\longrightarrow}$ & & $\begin{array}{llll}\infty & 0 & 0 & 0 \\
0 & 0 & 0 & 0 \\
\end{array}$ & 10 & & $\begin{array}{r}0000 \\
--00 \\
-\end{array}$ & 9 & & $\begin{array}{l}\because 0 \infty \infty \\
\therefore-100 \\
-0\end{array}$ & 0 & & $\begin{array}{l}N 0 \infty 0 \\
\therefore-10 \\
-10\end{array}$ \\
\hline \multirow{2}{*}{$\approx$} & $\dddot{7}$ & 요 & & $\begin{array}{l}0000 \\
-0000 \\
-00\end{array}$ & 另 & & $\begin{array}{lll}0 & \pi & \pi \\
0 & 0 & 0 \\
\end{array}$ & 吕 & & \begin{tabular}{lll|}
0 & $\pi$ & $\pi$ \\
0 & 0 & 0
\end{tabular} & in & & $\begin{array}{l}\dot{\nabla} \nabla \dot{0} \\
\dot{0} 0 \dot{0} 0 \dot{0}\end{array}$ \\
\hline & $\approx$ & n & & $\begin{array}{llll}0 & 0 & 0 & 0 \\
0 & 0 & 0 & 0 \\
\end{array}$ & 움 & & 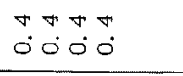 & $n$ & & 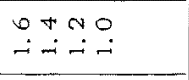 & 0 & & 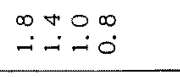 \\
\hline \multirow{7}{*}{ 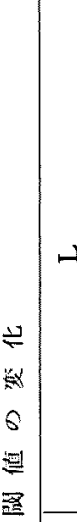 } & $\infty$ & 9 & $\mathscr{\sim}$ & 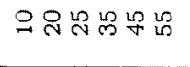 & 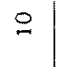 & 9 & 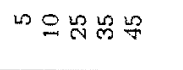 & ㅁ & $\vec{?}$ & ๓๓용 & 움 & 우 & 00020 \\
\hline & 范 & $\stackrel{n}{\rightarrow}$ & $\stackrel{L}{\rightarrow}$ & 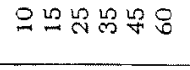 & 8 & $\stackrel{\mathscr{N}}{\sim}$ & 00980 & 우 & $\vec{a}$ & ம욤요 & $\stackrel{2}{7}$ & 吕 & OڤルL \\
\hline & $\frac{\pi}{r}$ & 8 & $\stackrel{L}{\mathrm{~N}}$ & ㅇㅇ요욤요 & 号 & 용 & 응ㅇㅁ욤 & \& & $\overrightarrow{8}$ & Oо口о & 品 & ถิ & ம으음묘 \\
\hline & 学 & 9 & $\stackrel{2}{2}$ & 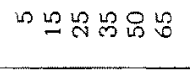 & $\stackrel{8}{2}$ & 尺े & 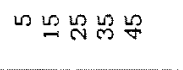 & P & 8 & 0020 & 织 & 용 & 0009 \\
\hline & 夋 & 0 & $\stackrel{\circ}{\longrightarrow}$ & 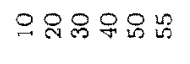 & $\circ$ & L & 응용ㄴㅇ용 & ద & 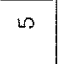 & 늠ㅇㅁㅁ뭉 & 논 & 욱 & 0000 \\
\hline & 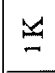 & $\stackrel{2}{\longrightarrow}$ & $\stackrel{L}{\longrightarrow}$ & 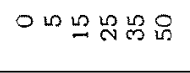 & is & $n$ & 윽음윰요 & 9 & $\omega$ & 으요용 & $\circ$ & $\circ$ & 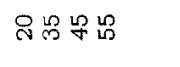 \\
\hline & 8 & 우 & $\stackrel{2}{-}$ & 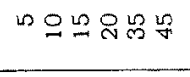 & $\circ$ & 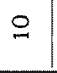 & 以ᄋ岩品骂 & $\stackrel{\circ}{-1}$ & 용 & 늑엉ㅇㅇㅇㅜ & 0 & $\circ$ & 里员点虽 \\
\hline \multirow{7}{*}{$\approx$} & $\infty$ & $\stackrel{\mathscr{L}}{\rightarrow}$ & $\stackrel{ }{(1)}$ & 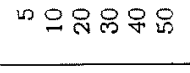 & 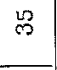 & $\stackrel{8}{\circ}$ & 요ㅇㅛㅛ묘요 & P & $\mathscr{2}$ & 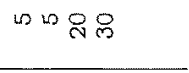 & $\stackrel{n}{=}$ & 8 & 유요아 \\
\hline & 농 & 品 & 岕 & ㅇㅇ음용요 & 号 & ৪ & 응요 & 욱 & $\vec{\circ}$ & 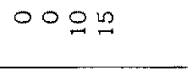 & 8 & 움 & "요요요 \\
\hline & $\frac{7}{7}$ & 9 & $\stackrel{2}{2}$ & 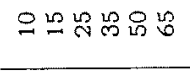 & 足 & 吕 & 0012 & 诘 & $\overrightarrow{0}$ & 0000 & 옹 & 号 & 00 느음 \\
\hline & 幽 & is & LD & 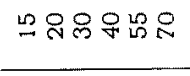 & 盟 & 8 & 0000 & 온 & $\overrightarrow{0}$ & 00010 & 品 & 是 & $00 \mathrm{NO}$ \\
\hline & $\stackrel{\nu}{N}$ & o & us & 목只邑另吕吕 & 品 & 묭 & 0009 & w & in & 00 유유 & 亗 & 吕 & 느용 \\
\hline & $\underset{1}{2}$ & $\infty$ & 10 & 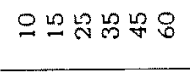 & 우 & 古 & 으으응요 & wo & 0 & 으묨용 & o & $\infty$ & 只品㱑品 \\
\hline & 8 & 0 & 20 & 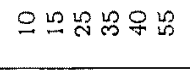 & $\stackrel{p}{\circ}$ & 字 & ம음요 & 음 & $\omega$ & n요욤 & 0 & 20 & 오옷몽우 \\
\hline \multirow[t]{2}{*}{ 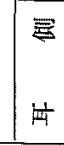 } & 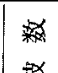 & $\begin{array}{l}\text { 駡 } \\
\sqrt[3]{x} \\
\sqrt{x}\end{array}$ & 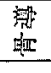 & \multirow{2}{*}{ 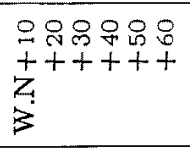 } & 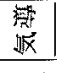 & 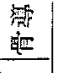 & \multirow{2}{*}{ 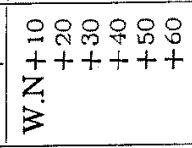 } & 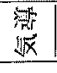 & 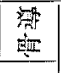 & \multirow{2}{*}{$\begin{array}{l}\text { 용ㅇㅇㅇㅇㅇㅇㅇㅇ } \\
++++++ \\
z \\
3\end{array}$} & $\begin{array}{l}\text { 淛 } \\
\sqrt{x} \\
\end{array}$ & 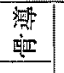 & \multirow{2}{*}{ 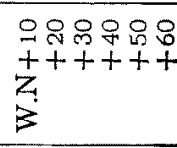 } \\
\hline & 監 & 紫 & & & 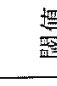 & & & 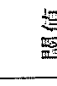 & & & 還 & & \\
\hline \multicolumn{2}{|c|}{ 糔性些区 } & \multicolumn{3}{|c|}{ 汶 } & \multicolumn{3}{|c|}{ 等 } & \multicolumn{3}{|c|}{ 政 } & \multicolumn{3}{|c|}{ 踏 } \\
\hline \multicolumn{2}{|c|}{ 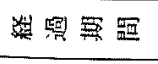 } & \multicolumn{3}{|r|}{$\stackrel{\frac{14}{4}}{\square}$} & \multicolumn{3}{|r|}{ 苦 } & \multicolumn{3}{|r|}{ 坓 } & \multicolumn{3}{|r|}{$\stackrel{40}{\circ}$} \\
\hline \multicolumn{2}{|l|}{$\$$} & \multicolumn{3}{|r|}{ 㧽 } & \multicolumn{3}{|r|}{ 政 } & \multicolumn{3}{|r|}{$\equiv$} & \multicolumn{3}{|r|}{ 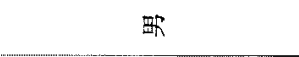 } \\
\hline 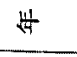 & $\ll \mathbb{F}$ & & & $\tilde{m}$ & & & बे & & & ले & & & $\stackrel{\infty}{*}$ \\
\hline 焉 & & & & 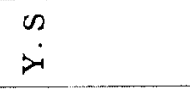 & & & $\begin{array}{l}I \\
\dot{z}\end{array}$ & & & $\ddot{2}$ & & & $\Sigma$ \\
\hline 謀 承 & & & & $N$ & & & $\infty$ & & & $\nabla$ & & & 10 \\
\hline
\end{tabular}




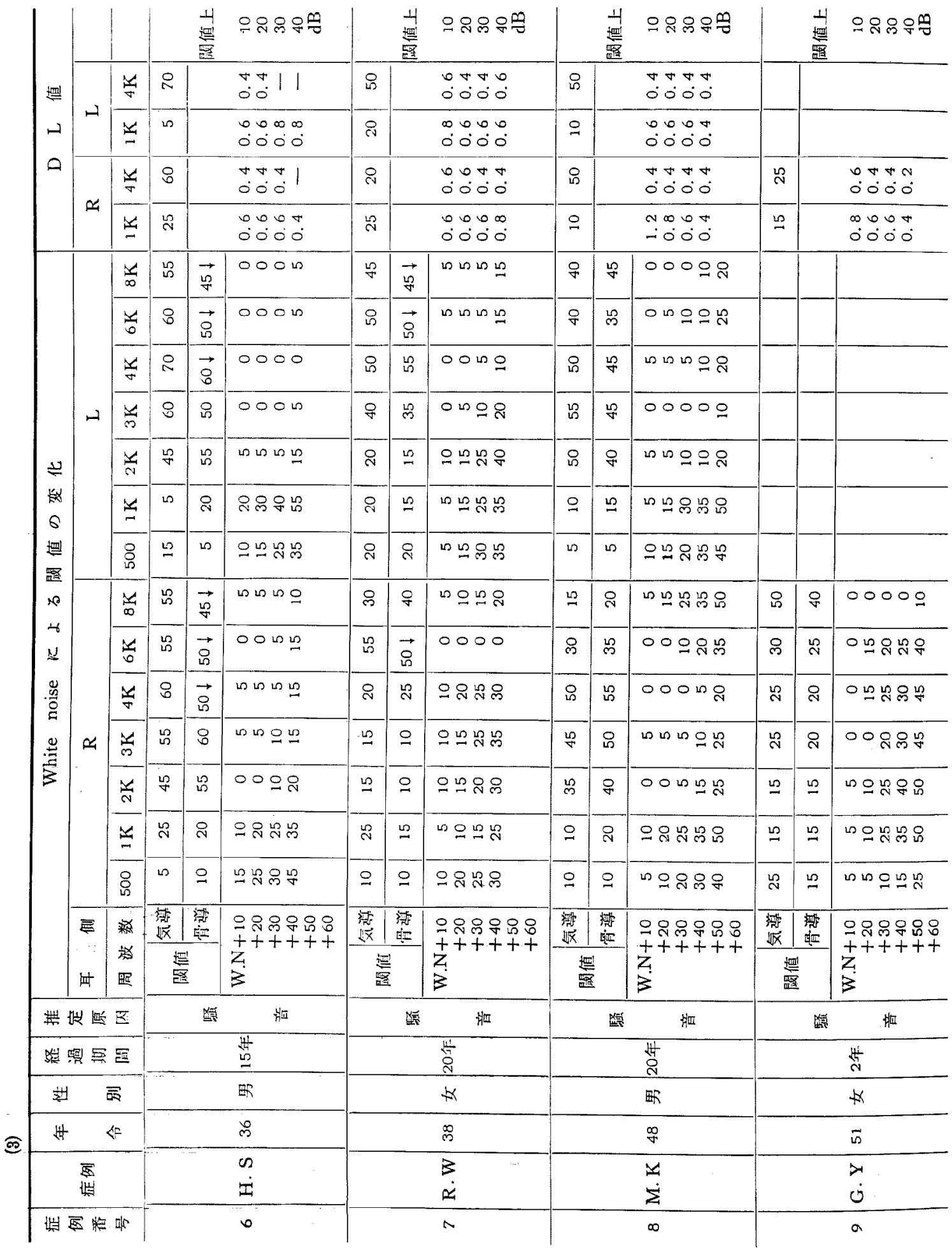




\begin{tabular}{|c|c|c|c|c|c|c|c|c|c|c|c|c|c|c|}
\hline \multirow{5}{*}{$\begin{array}{l}\text { 幽 } \\
\text { A } \\
0\end{array}$} & & & & $\begin{array}{l}4 \\
\text { 谓 } \\
\text { 霆 } \\
\end{array}$ & 유ㅇㅛㅠㅇㅠ & & 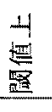 & 으용윰ㅁㅁ & & 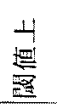 & 으융유뮤 & & 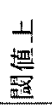 & 으용유욤 \\
\hline & \multirow{2}{*}{ - } & $\stackrel{y}{\forall}$ & 웁 & & $\begin{array}{l}\infty \nabla \nabla \nabla \\
000\end{array}$ & $\stackrel{6}{\sigma}$ & & $\begin{array}{l}\text { पं पें } \\
0000\end{array}$ & & & & $\stackrel{\infty}{\infty}$ & & $\begin{array}{l}0 \% \pi \nabla \\
0000\end{array}$ \\
\hline & & $\underline{-}$ & 42 & & $\begin{array}{l}\because 0 \infty \infty \\
-200\end{array}$ & 0 & & $\begin{array}{llll}0 & 0 & 0 & 0 \\
0 & 0 & 0 & 0\end{array}$ & & & & ஜ & & 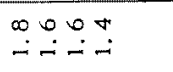 \\
\hline & \multirow{2}{*}{$\propto$} & 采 & $\stackrel{5}{4}$ & & $\begin{array}{l}0 \nabla \nabla 7 \\
0000\end{array}$ & $\stackrel{n}{\nabla}$ & & $\begin{array}{l}0 \text { प } \\
00 \\
0\end{array}$ & 尺 & & $\begin{array}{l}0000 \\
000 \\
0\end{array}$ & $\stackrel{D}{\circ}$ & & $\begin{array}{l}0+\pi \\
000 \\
00\end{array}$ \\
\hline & & $\underline{=}$ & 0 & & 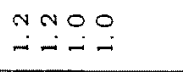 & 0 & & 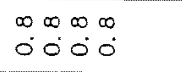 & 1 & & $\begin{array}{l}+\infty 00 \\
-0.0 \\
-0\end{array}$ & $\stackrel{\sim}{\sim}$ & & 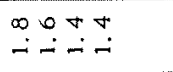 \\
\hline \multirow{12}{*}{ 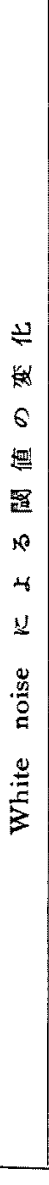 } & \multirow{7}{*}{$\mapsto$} & $\underset{\infty}{\infty}$ & 8 & 足 & ○ レนเ & 品 & ஜ & 능요 & & & & ஜ & $\stackrel{m}{m}$ & แนดำ \\
\hline & & $\frac{1}{b}$ & 움 & 8 & ๒レレ요요 & $\stackrel{m}{\infty}$ & 움 & ำ윰ำ & & & & $\mathscr{2}$ & P & OnO는 \\
\hline & & $\underset{\forall}{\check{\nabla}}$ & 우 & 8 & மn으으요요 & 䑰 & $\frac{6}{4}$ & O & & & & 卢 & 沾 & O \\
\hline & & 番 & ஜ & ஓ & 이으늠유 & ह & p & ம용요 & & & & 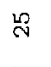 & ค & 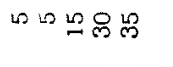 \\
\hline & & $\frac{N}{N}$ & $n$ & 용 & 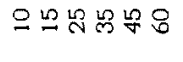 & $\underline{\omega}$ & $\stackrel{\circ}{\circ}$ & 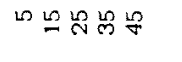 & & & & 尺 & 8 & แ유유 \\
\hline \multirow{4}{*}{$\begin{array}{l}2 \\
0 \\
0 \\
0\end{array}$} & & $\underline{z}$ & 10 & 10 & 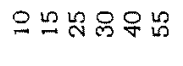 & 0 & $\bigcirc$ & 는ำำ용ำ & & & & 尺् & 요 & ம요ㅇㅠㅛ \\
\hline & & 8 & $\circ$ & 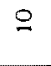 & 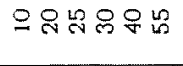 & 음 & 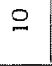 & ம묨용 & & & & $\stackrel{2}{-}$ & 요 & 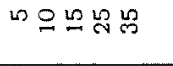 \\
\hline & \multirow{7}{*}{$\simeq$} & $\frac{x}{\infty}$ & 8 & $\vec{y}$ & 00102 & $\omega$ & 0 & 응요윤윤 & 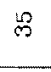 & 8 & ం & 욤 & 8 & 00000 \\
\hline & & $\frac{y}{b}$ & น็ & $\overrightarrow{8}$ & 000010 & $\stackrel{n}{\sim}$ & $\stackrel{0}{\infty}$ & ంద요 & 유 & $\mathscr{9}$ & 0 01098 & 온 & $\mathscr{Z}$ & O \\
\hline & & V & $\stackrel{6}{7}$ & ถึ & 00092 & $\stackrel{\leftarrow}{t}$ & 웜 & 0 & $\stackrel{乛}{N}$ & $\stackrel{\sim}{N}$ & ம용요움 & $\stackrel{2}{\infty}$ & 우 & 이늠요 \\
\hline & & 学 & $\mathscr{2}$ & 웁 & ㅇ요요 & 8 & ฉి & นㅇํㅇํำ & $?$ & $\stackrel{0}{\rightarrow}$ & 용용요 & ஜ् & ஓ & 느능요운 \\
\hline & & N & 욱 & $\stackrel{\infty}{\infty}$ & 00199 & $\stackrel{2}{=}$ & § & ๘녁농웅요 & $i$ & $i$ & 유유운용 & 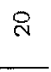 & $\stackrel{\sim}{N}$ & 응요 \\
\hline & & $\underline{Z}$ & 0 & 40 & 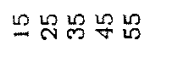 & $\circ$ & in & 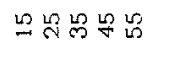 & $i$ & $i$ & 유용웅용 & \& & $\stackrel{2}{2}$ & 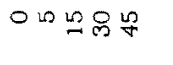 \\
\hline & & 8 & 1 & 10 & 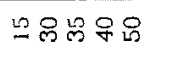 & 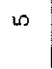 & 10 & 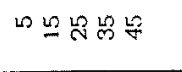 & 0 & 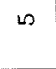 & 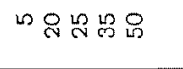 & $\stackrel{2}{2}$ & 음 & 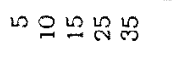 \\
\hline & \multirow[t]{2}{*}{ 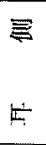 } & 梷 & $\begin{array}{l}\text { 就: } \\
\text { 返 } \\
\end{array}$ & 翟 & \multirow{2}{*}{ 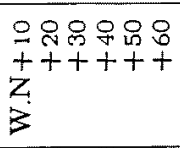 } & 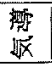 & 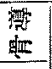 & \multirow{2}{*}{$\begin{array}{l}0880980 \\
+++++4 \\
z \\
3\end{array}$} & $\begin{array}{l}\text { 部 } \\
\text { 震 }\end{array}$ & 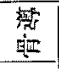 & \multirow{2}{*}{$\begin{array}{l}\text { 용ㅇㅇㅇㅇㅇ } \\
++t++t \\
Z \\
3\end{array}$} & 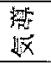 & 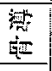 & \multirow{2}{*}{$\begin{array}{l}\text { 응ㅇㅇㅇㅇㅇㅇㅇ } \\
++++++ \\
z \\
3\end{array}$} \\
\hline & & 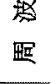 & 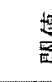 & & & 探 & & & te & & & 塞 & & \\
\hline \multicolumn{3}{|c|}{ 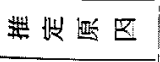 } & \multicolumn{3}{|c|}{ 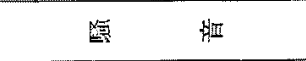 } & \multicolumn{3}{|c|}{ 虽 } & \multicolumn{3}{|c|}{ 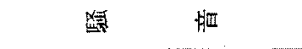 } & \multicolumn{3}{|c|}{ 留 } \\
\hline \multicolumn{3}{|c|}{ 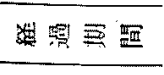 } & \multicolumn{3}{|r|}{ 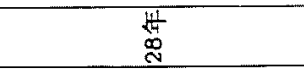 } & \multicolumn{3}{|r|}{$\stackrel{4}{4}$} & \multicolumn{3}{|r|}{$\begin{array}{l}\text { 㟧 } \\
0 \\
\end{array}$} & \multicolumn{3}{|r|}{$\stackrel{5}{=}$} \\
\hline \multicolumn{3}{|c|}{ 非 } & \multicolumn{3}{|r|}{$\mathbb{R}$} & \multicolumn{3}{|r|}{$E$} & \multicolumn{3}{|r|}{$M$} & \multicolumn{3}{|r|}{$K$} \\
\hline सै & & 价 & & & $\underset{\sim}{\Psi}$ & & & 요 & & & 눈 & & & 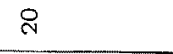 \\
\hline & 裍 & & & & $\begin{array}{l}I \\
\check{I}\end{array}$ & & & $\begin{array}{l}< \\
\dot{4}\end{array}$ & & & $\stackrel{H}{-}$ & & & $\stackrel{I}{\Sigma}$ \\
\hline & 5 & & & & $\cong$ & & & $=$ & & & $\cong$ & & & $\stackrel{2}{-}$ \\
\hline
\end{tabular}




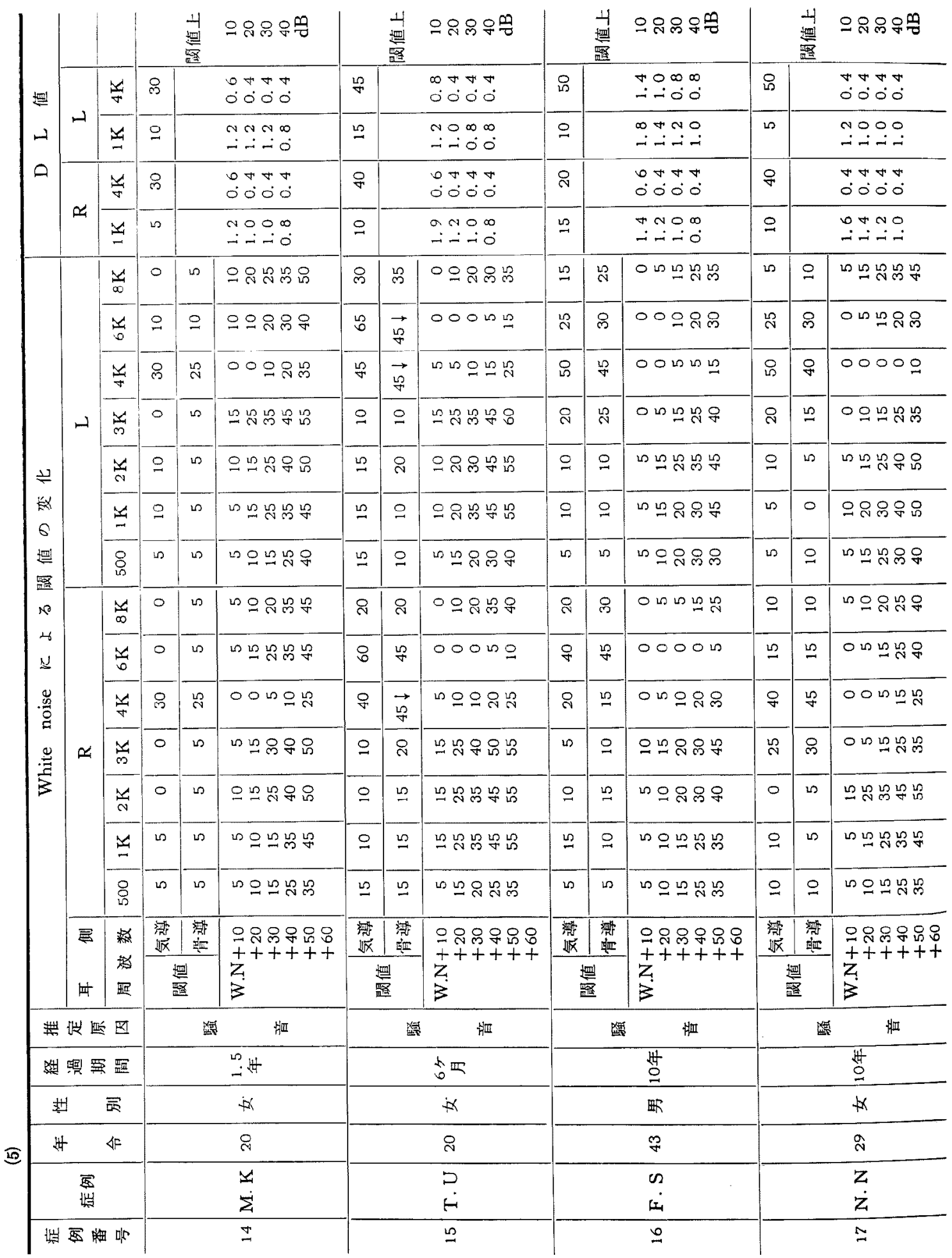




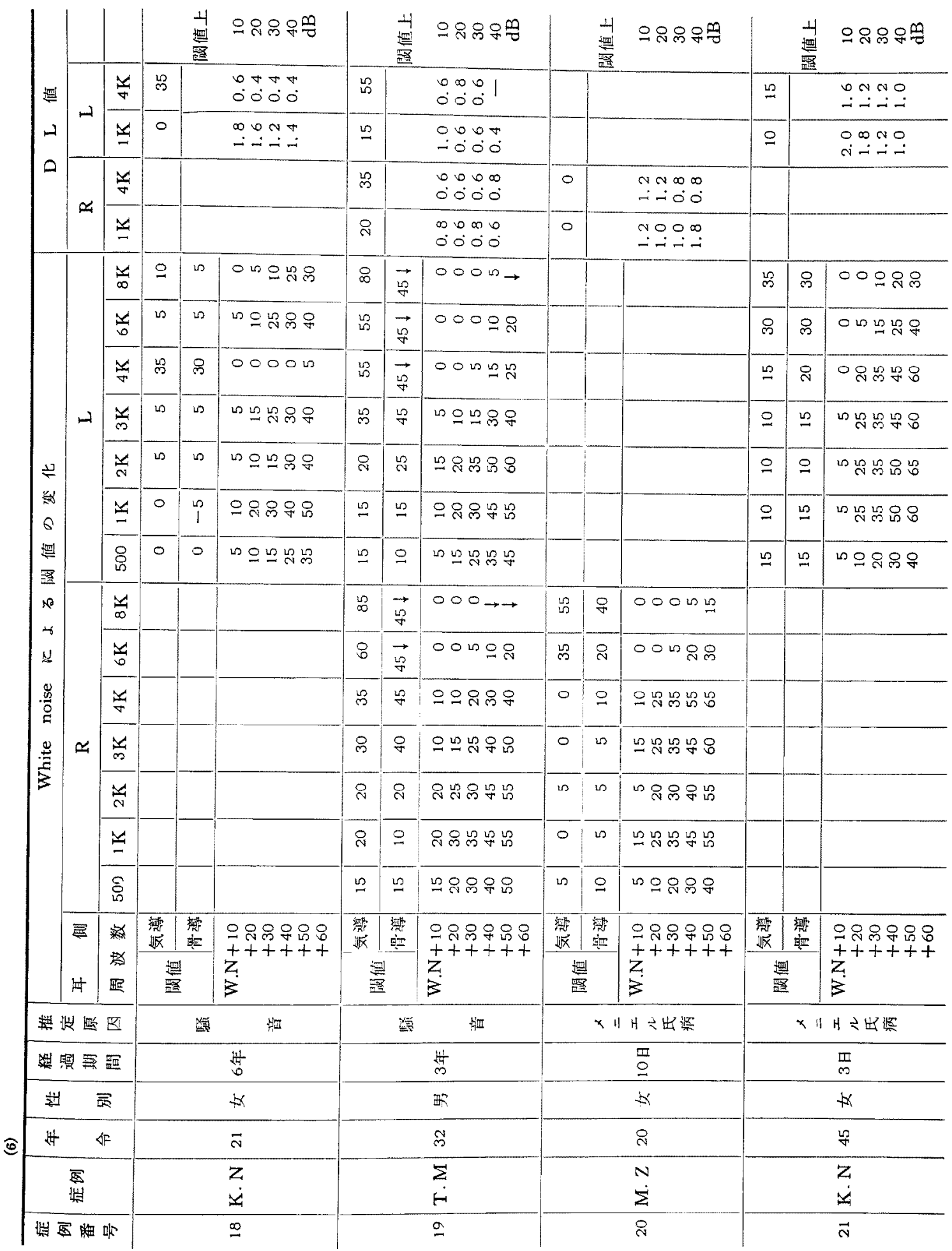




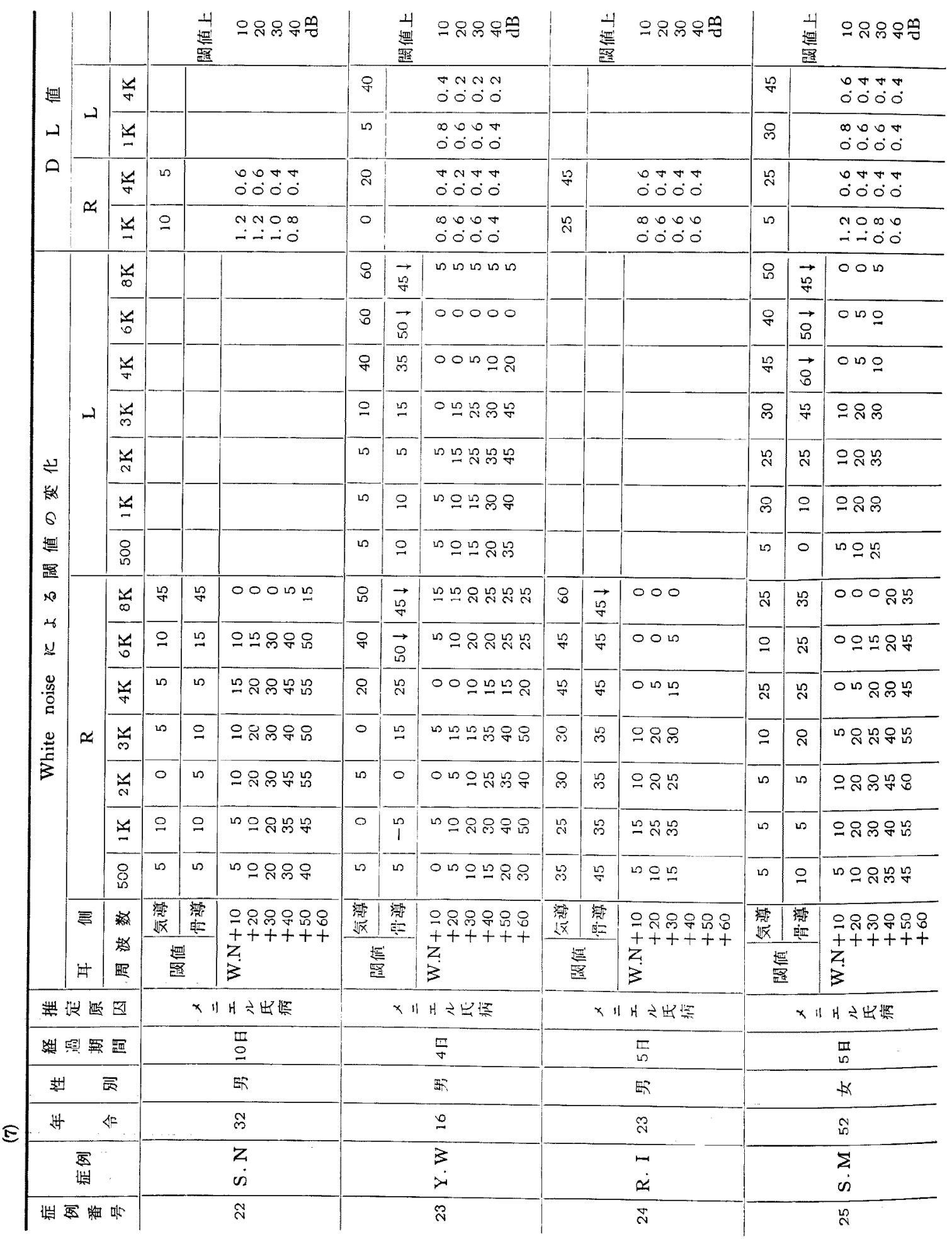




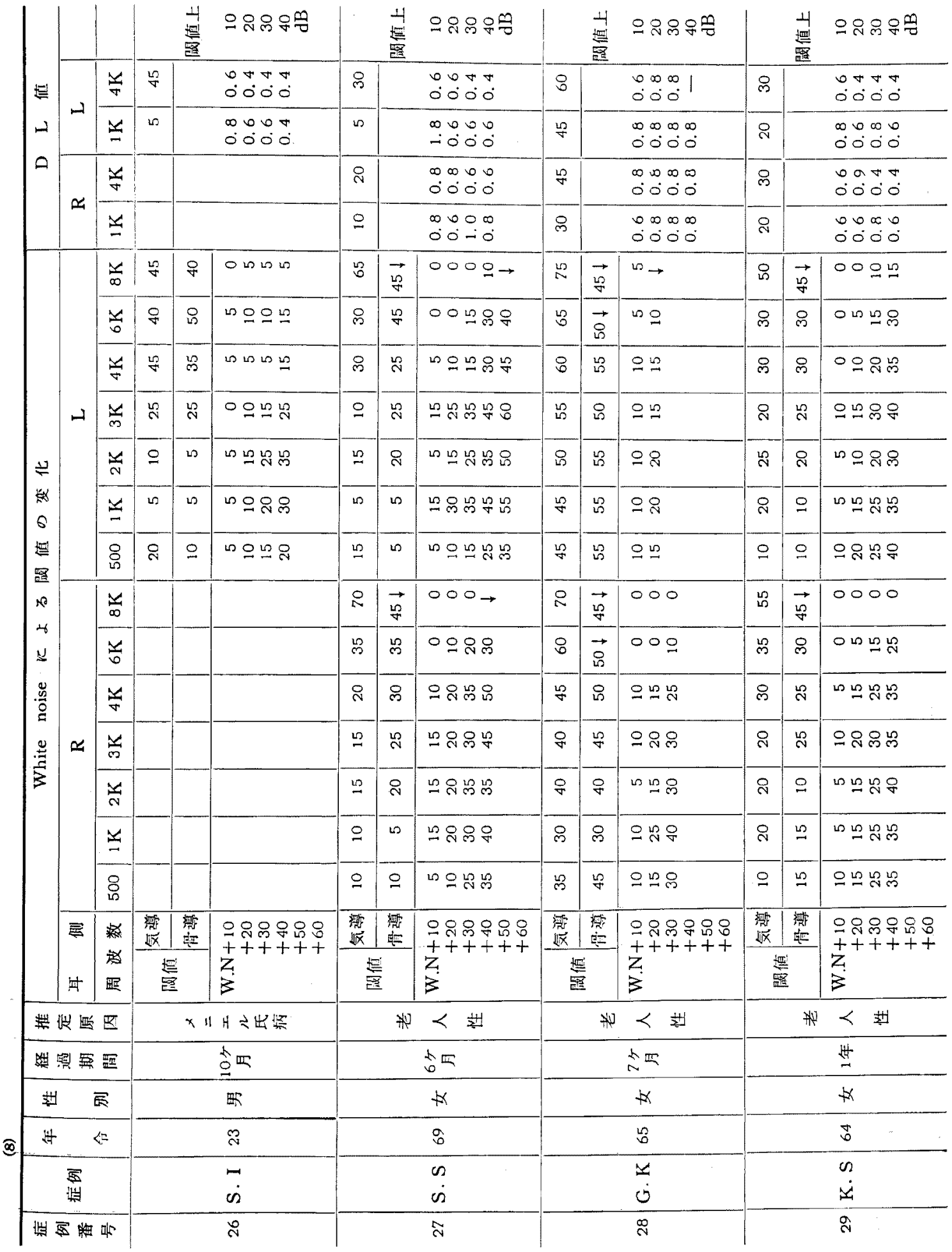




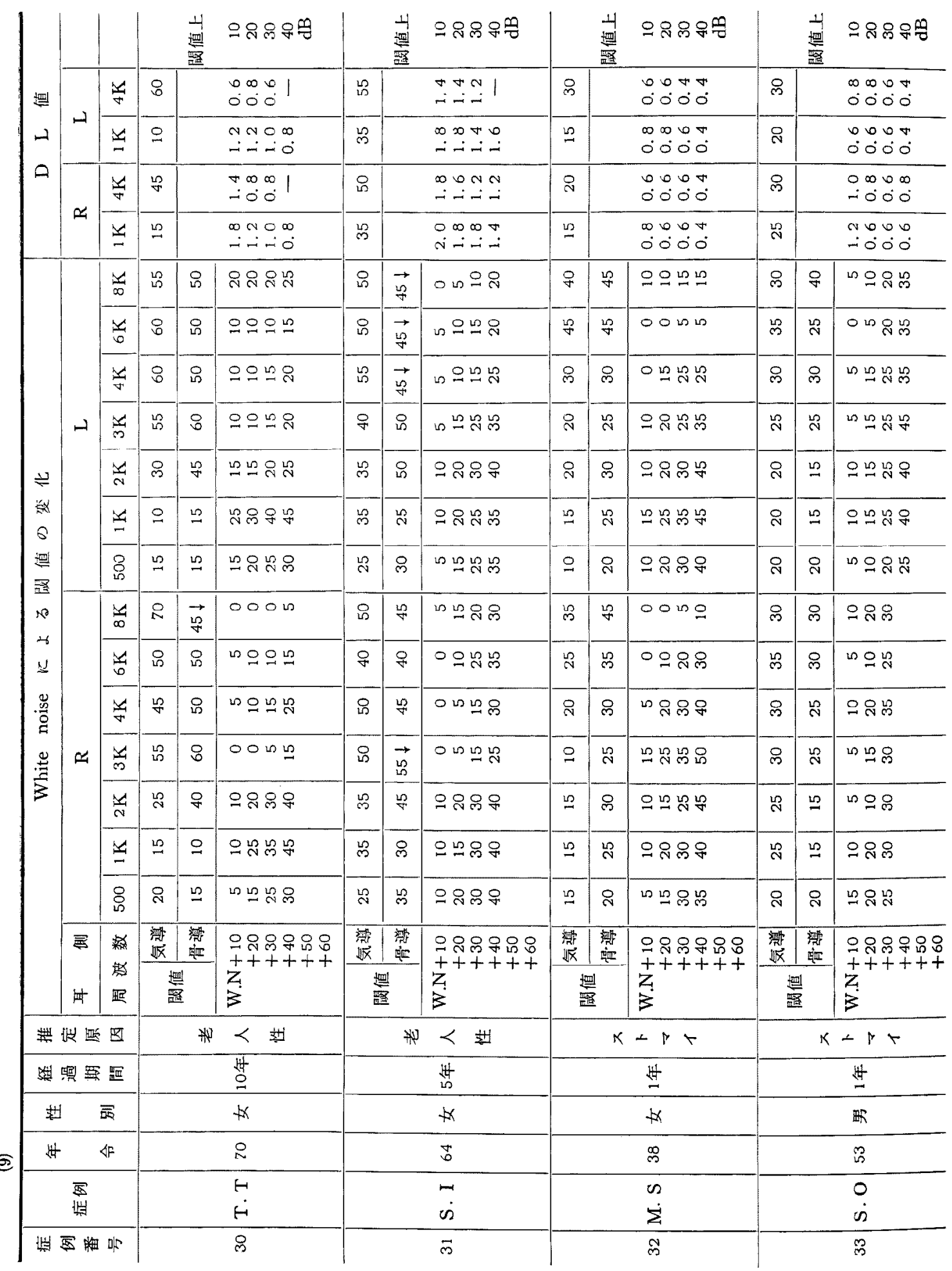




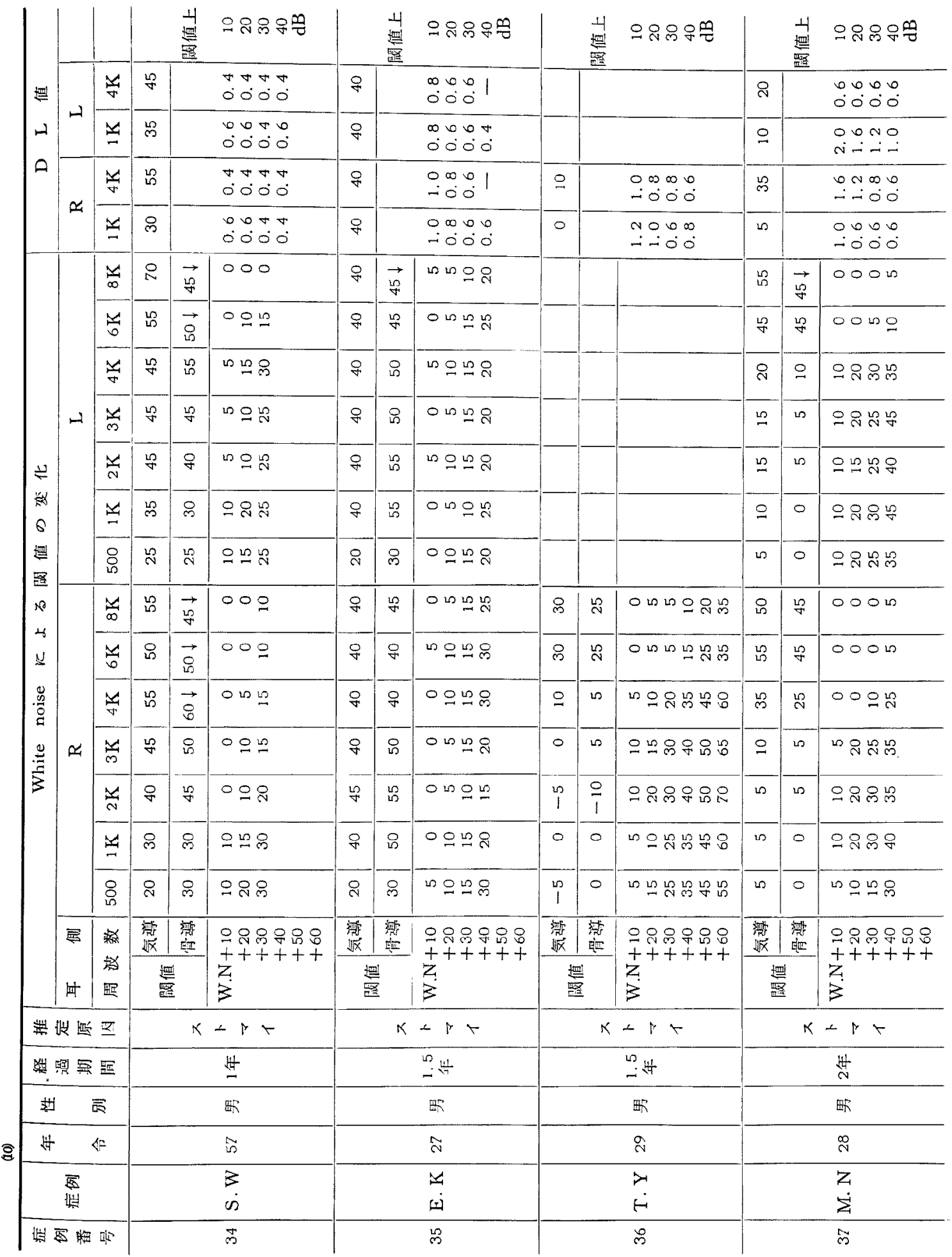




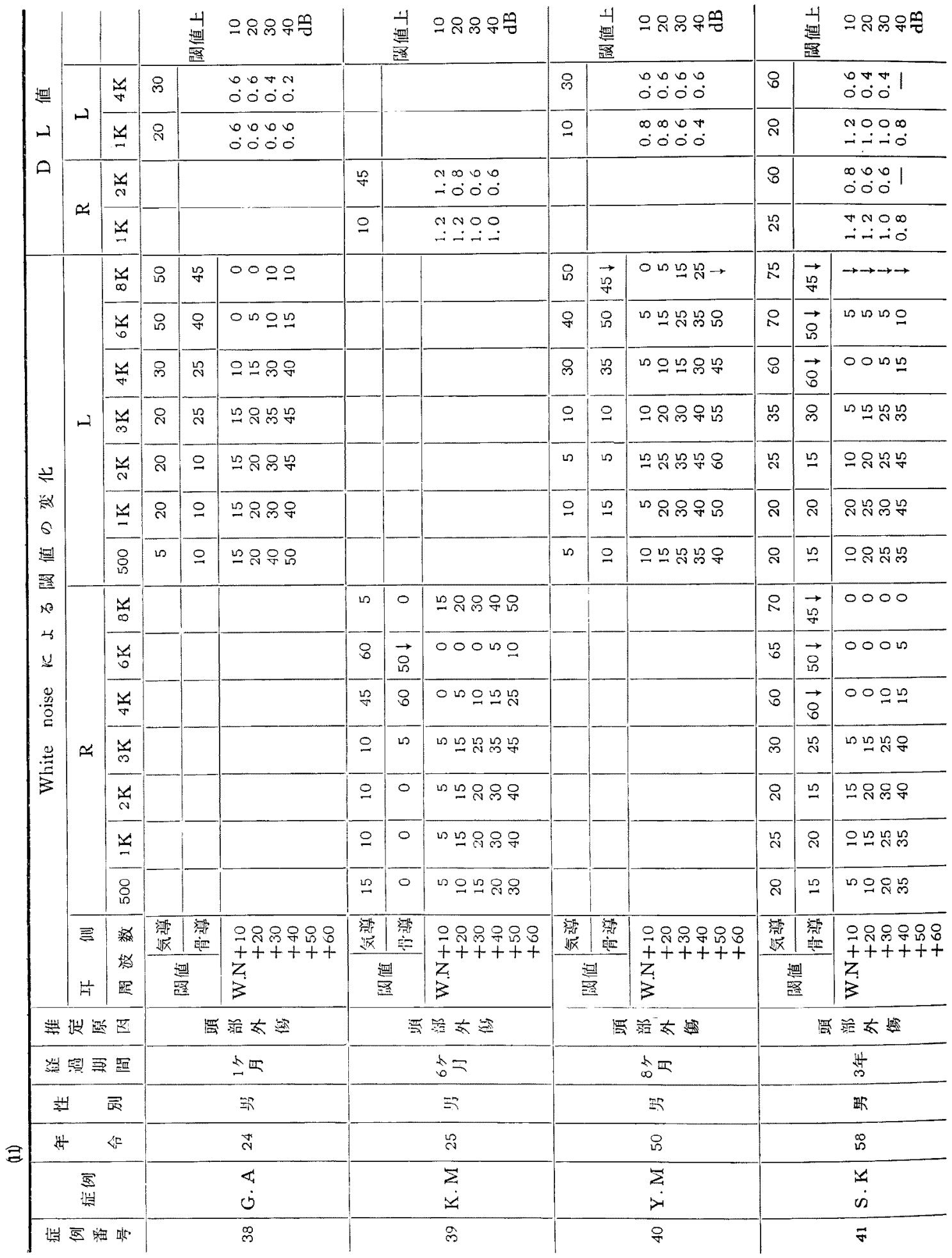




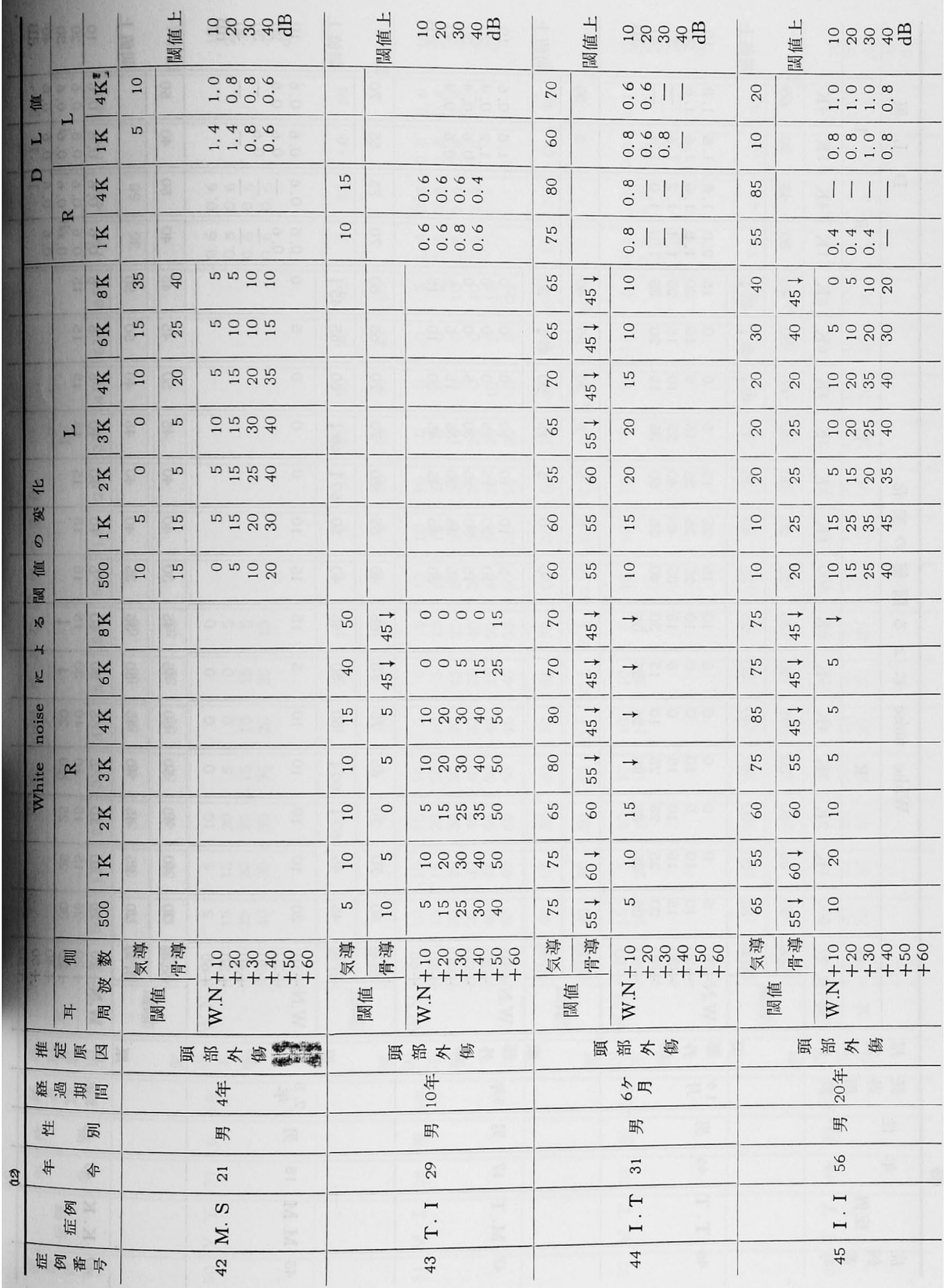




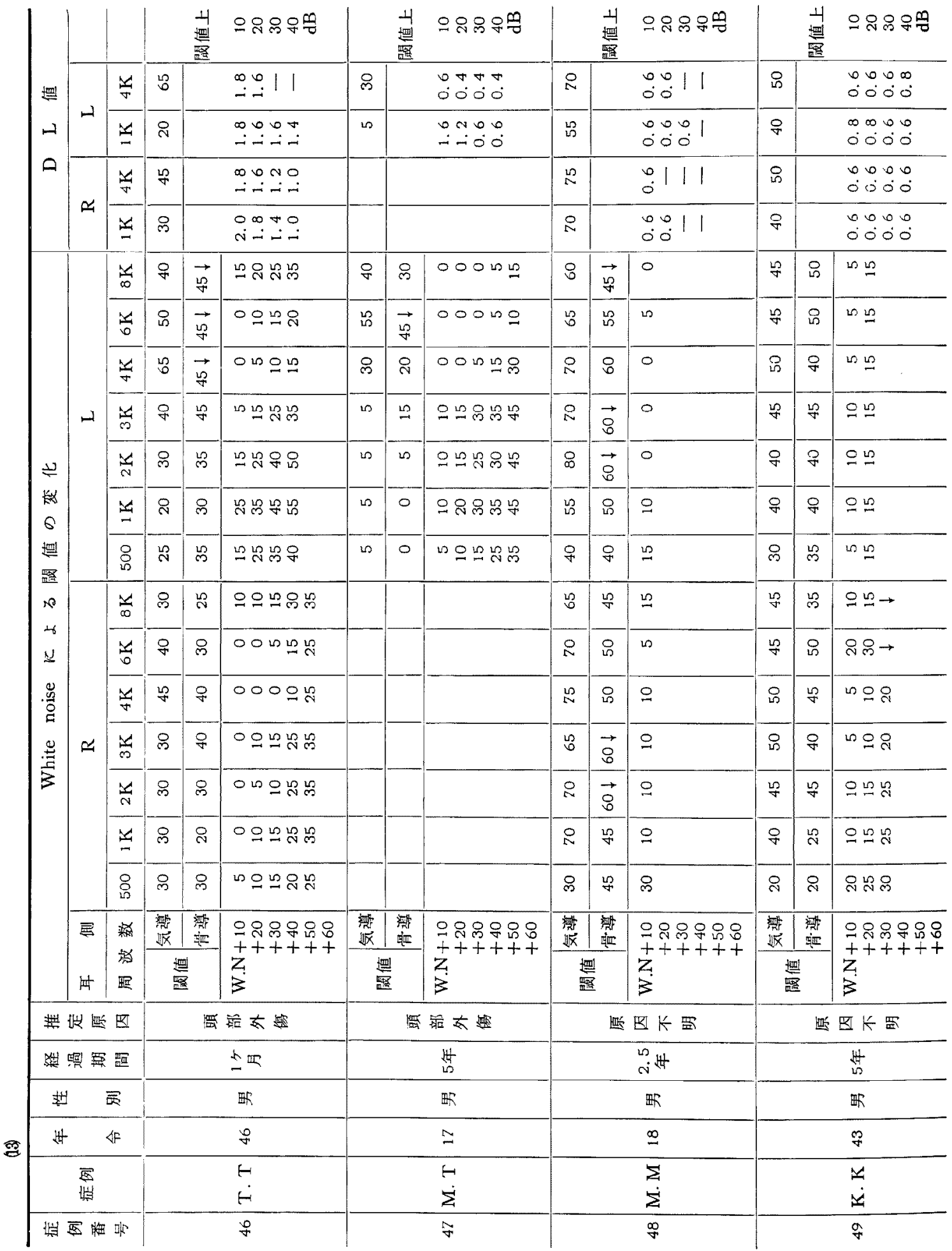




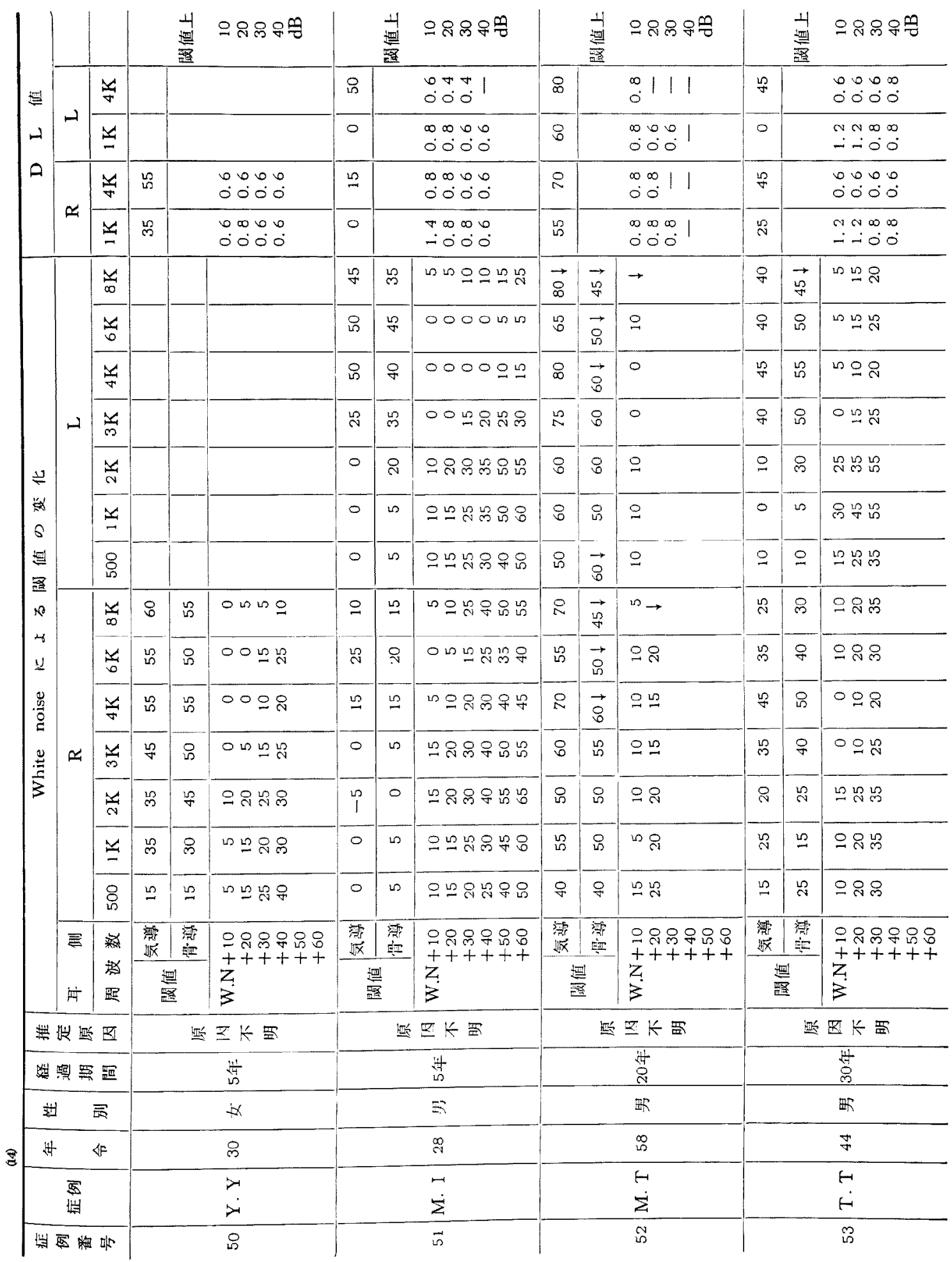




\begin{tabular}{|c|c|c|c|c|c|c|c|c|c|c|c|c|c|c|}
\hline \multirow{5}{*}{$\begin{array}{l}\text { 龭 } \\
-1 \\
0\end{array}$} & & & & 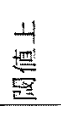 & 응용ㅇㅁㅁㅁㅁㅁ & & 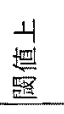 & 용용ㅇㅁ뵹 & & 崖 & 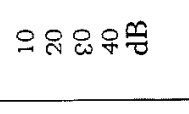 & & $\begin{array}{l}4 \\
\text { 㩊 } \\
\text { 路 }\end{array}$ & 응요 움ํㅟ \\
\hline & \multirow[b]{2}{*}{\lrcorner} & $\because$ & in & & $\begin{array}{llll}0 & 0 & 0 & 1 \\
0 & 0 & 0 & 1\end{array}$ & $\stackrel{\leftrightarrow \rho}{\leftrightarrow}$ & & $\begin{array}{llll}\infty & 0 & \pi & 1 \\
0 & 0 & 0 & 0\end{array}$ & $\mathscr{8}$ & & $\begin{array}{l}0 \infty 00 \\
-000 \\
\end{array}$ & $\stackrel{\mathscr{m}}{\mathscr{m}}$ & & 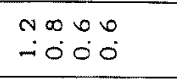 \\
\hline & & $\stackrel{x}{=}$ & in & & $\begin{array}{l}\infty 000 \\
0.00 \\
000\end{array}$ & 우 군 & & $\begin{array}{llll}\infty & 0 & \forall \\
0 & 0 & 0 & 0 \\
0 & 0\end{array}$ & $\cong$ & & 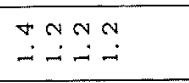 & $\stackrel{m}{m}$ & & $\begin{array}{l}0 \infty 00 \\
-00-1 \\
\end{array}$ \\
\hline & \multirow{2}{*}{$\infty$} & $\frac{x}{4}$ & 吕 & & \begin{tabular}{ll|l|}
0 & 0 & 1 \\
0 & 0 & 1
\end{tabular} & 옹 & & 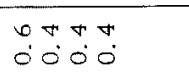 & $\stackrel{n}{i}$ & & $\begin{array}{l}0000 \\
\therefore-0 \\
-0\end{array}$ & 우 & & 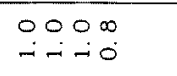 \\
\hline & & $\underline{-x}$ & 0 & & $\begin{array}{l}0000 \\
00 \\
0\end{array}$ & 윰 & & $\begin{array}{l}0 \pi+0 \\
0000 \\
000\end{array}$ & $\cong$ & & $\begin{array}{l}0 \infty \infty \infty \\
=-0 \\
-10\end{array}$ & $\stackrel{m}{m}$ & & $\begin{array}{l}0000 \\
000 \\
-100 \\
\end{array}$ \\
\hline \multirow{7}{*}{\multicolumn{2}{|c|}{ 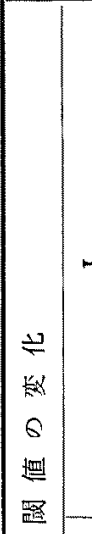 }} & $\underset{\infty}{\infty}$ & 点 & 움 & ำ & $\mathscr{q}$ & 号 & 는 & 采 & 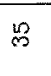 & $000 \mathrm{~m}$ & 80 & $\vec{b}$ & 응ㅇㅇ \\
\hline & & 幽 & 8 & 8 & 느욤요 $\rightarrow$ & 8 & 8 & 01 & $\stackrel{\infty}{\sim}$ & 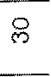 & ம요 & 尔 & $\overrightarrow{0}$ & 욤묘 \\
\hline & & 兴 & 品 & 蚞 & 요요욤요 & 足 & 용 & nO & $\stackrel{2 n}{\sim}$ & 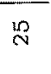 & ம유요 & $\ddot{\circ}$ & 암 & 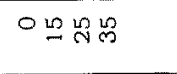 \\
\hline & & $\frac{m}{m}$ & 吕 & 乎 & 009 & 员 & $\stackrel{\text { 누 }}{\longrightarrow}$ & $\curvearrowleft O$ & \& & $\stackrel{n}{\sim}$ & 10 냄요 & $\stackrel{\mathscr{m}}{2}$ & 品 & 으용요 \\
\hline & & $\frac{1}{4}$ & 8 & 8 & 오욤못 品 & $\stackrel{\mathscr{T}}{T}$ & $\stackrel{\leftrightarrow}{\square}$ & 는 & $\mathscr{2}$ & 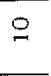 & 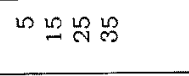 & ஜ్ల & $\infty$ & 으유요 \\
\hline & & $\underset{z}{2}$ & is & $\circ$ & 옹品号骂 & 윰 & $\stackrel{\circ}{9}$ & n & 은 & $\stackrel{\circ}{\circ}$ & 융ㅇㅁㅇ & $\stackrel{\varphi}{\rho}$ & 品 & 의욤요 \\
\hline & & 8 & $\omega$ & $\omega$ & 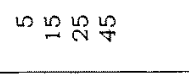 & $\stackrel{\mathscr{N}}{\mathrm{N}}$ & 点 & 요 & 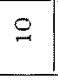 & 욱 & ๘요요 & ¿ & ஜ & 모욤요 \\
\hline \multirow{8}{*}{ 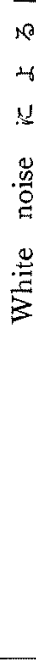 } & \multirow{7}{*}{ 幽 } & $\infty$ & 8 & $g$ & 응요용 & 8 & 용 & 00 & 亲 & $\stackrel{g}{q}$ & 00010 & 요 & 出 & 응으으는 \\
\hline & & 话 & 品 & 品 & 000 is & 온 & 呩 & 으 & $\stackrel{\mathscr{N}}{\Omega}$ & $\mathscr{m}$ & 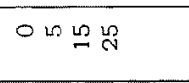 & 움 & $\stackrel{f}{f}$ & $\llcorner O$ \\
\hline & & 幽 & 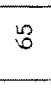 & 号 & 00010 & 웅 & 尔 & 는 & $\stackrel{n}{N}$ & $\stackrel{2}{=}$ & O & 운 & $\ddot{m}$ & 으묘 \\
\hline & & 部 & 8 & 8 & 0000 & 옹 & $\stackrel{\square}{\forall}$ & 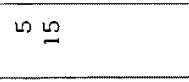 & $\mathscr{2}$ & 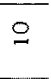 & ๘믐뭉 & 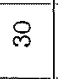 & ల్ల & ㅇㅇㅇㅇㅇㅇㅁ \\
\hline & & $\frac{\pi}{N}$ & 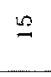 & ฉิ & 뮤욤요 & 占 & 우 & ๒上 & $\cong$ & $\infty$ & ๘ ृిలి & ஓి & ஜ & 으유요 \\
\hline & & $\cong$ & 0 & $\omega$ & 엇용ㅇㅁ용 & 윰 & 号 & 98 & $\stackrel{9}{2}$ & in & 늠용 & $\mathscr{2}$ & $\ddot{m}$ & ○レセロ \\
\hline & & 8 & $\infty$ & $\omega$ & 오븜용욕 & ஜ & ㅁ & 믐 & คิ & 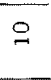 & 의온 & $\stackrel{\circ}{\circ}$ & 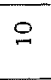 & 응요움 \\
\hline & \multirow[t]{2}{*}{ ₹ } & 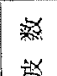 & 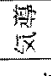 & 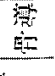 & \multirow{2}{*}{$\begin{array}{l}\text { 영요웅ㅇㅇㅇ } \\
+++++++1 \\
z \\
3\end{array}$} & 漂 & 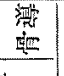 & \multirow{2}{*}{ 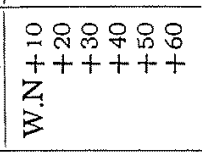 } & 河 & 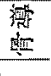 & \multirow{2}{*}{$\begin{array}{l}\text { 용ㅇㅇㅇㅇㅇ } \\
++++++ \\
z \\
3\end{array}$} & 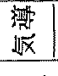 & 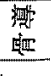 & \multirow{2}{*}{$\begin{array}{l}\text { 용ㅇㅇㅇㅇㅇ } \\
t+t++t \\
Z \\
3\end{array}$} \\
\hline & & 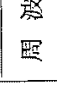 & t & & & to & & & 掹 & & & 逥 & & \\
\hline \multicolumn{3}{|c|}{ 击设㹂 } & \multicolumn{3}{|c|}{ 些正长置 } & \multicolumn{3}{|c|}{ 熙篮 } & \multicolumn{3}{|c|}{ 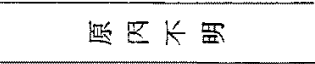 } & \multicolumn{3}{|c|}{ 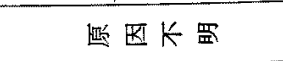 } \\
\hline \multicolumn{3}{|c|}{ 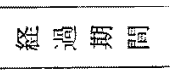 } & \multicolumn{3}{|c|}{$\stackrel{\frac{1}{3}}{8}$} & \multicolumn{3}{|c|}{ 范 } & \multicolumn{3}{|c|}{$\begin{array}{l}\text { 㗂 } \\
\text { K }\end{array}$} & \multicolumn{3}{|c|}{$\begin{array}{l}205 \\
-5 \\
-5\end{array}$} \\
\hline \multicolumn{3}{|c|}{ 菠 } & \multicolumn{3}{|r|}{ 些 } & \multicolumn{3}{|r|}{ 踏 } & \multicolumn{3}{|r|}{ m } & \multicolumn{3}{|r|}{ 毗 } \\
\hline & + & $<$ & & & $\bar{F}$ & & & $\stackrel{\sigma}{二}$ & & & 㳖 & & & is \\
\hline & $\begin{array}{l}\text { 昰 } \\
\text { 出 }\end{array}$ & & & & $\begin{array}{l}\infty \\
\infty\end{array}$ & & & $\begin{array}{l}0 \\
N\end{array}$ & & & $\begin{array}{l}I \\
\dot{n}\end{array}$ & & & $\begin{array}{l}\sum \\
\dot{v}\end{array}$ \\
\hline & E & & & & 出 & & & 识 & & & เீ & & & ก \\
\hline
\end{tabular}




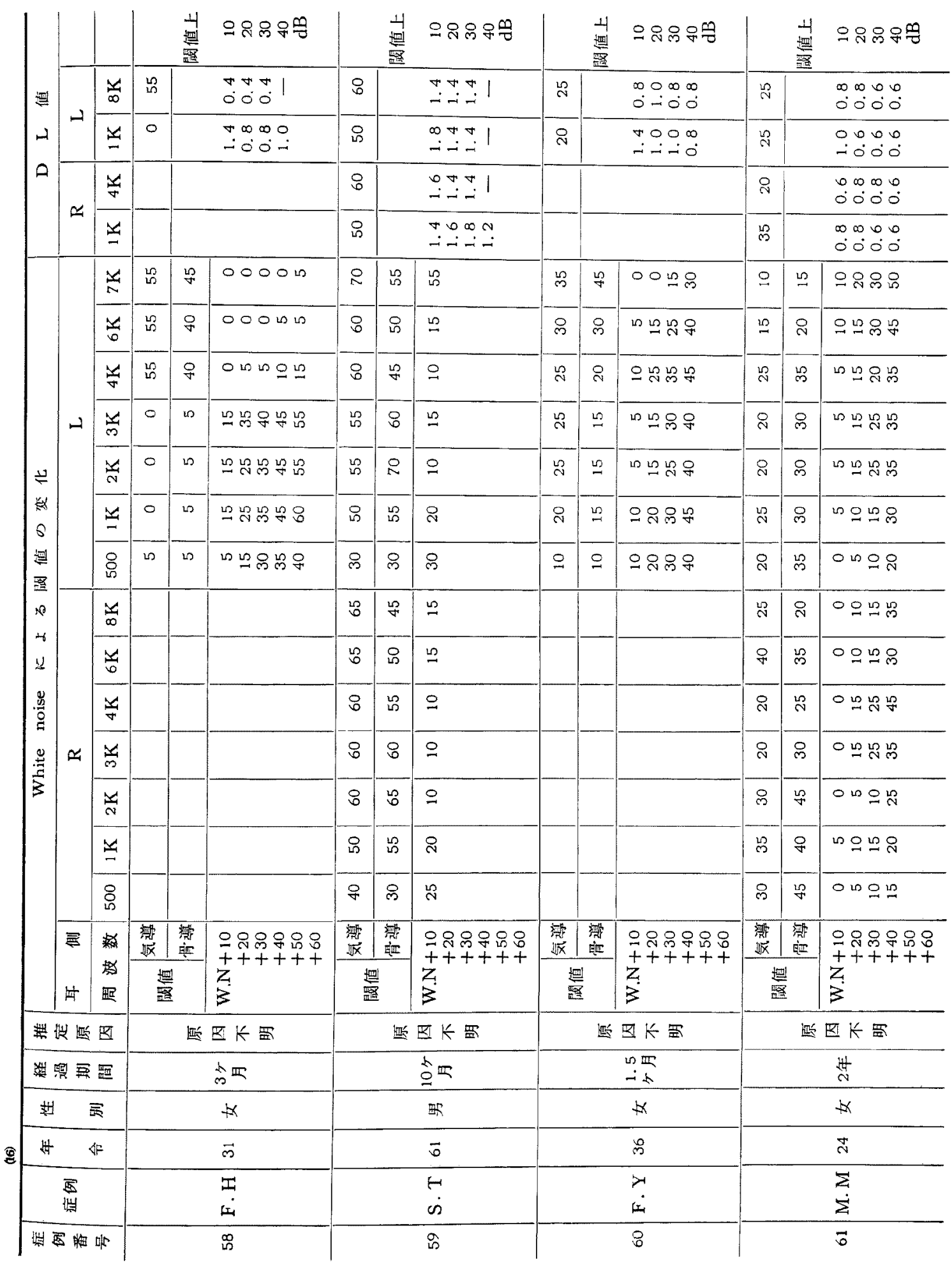




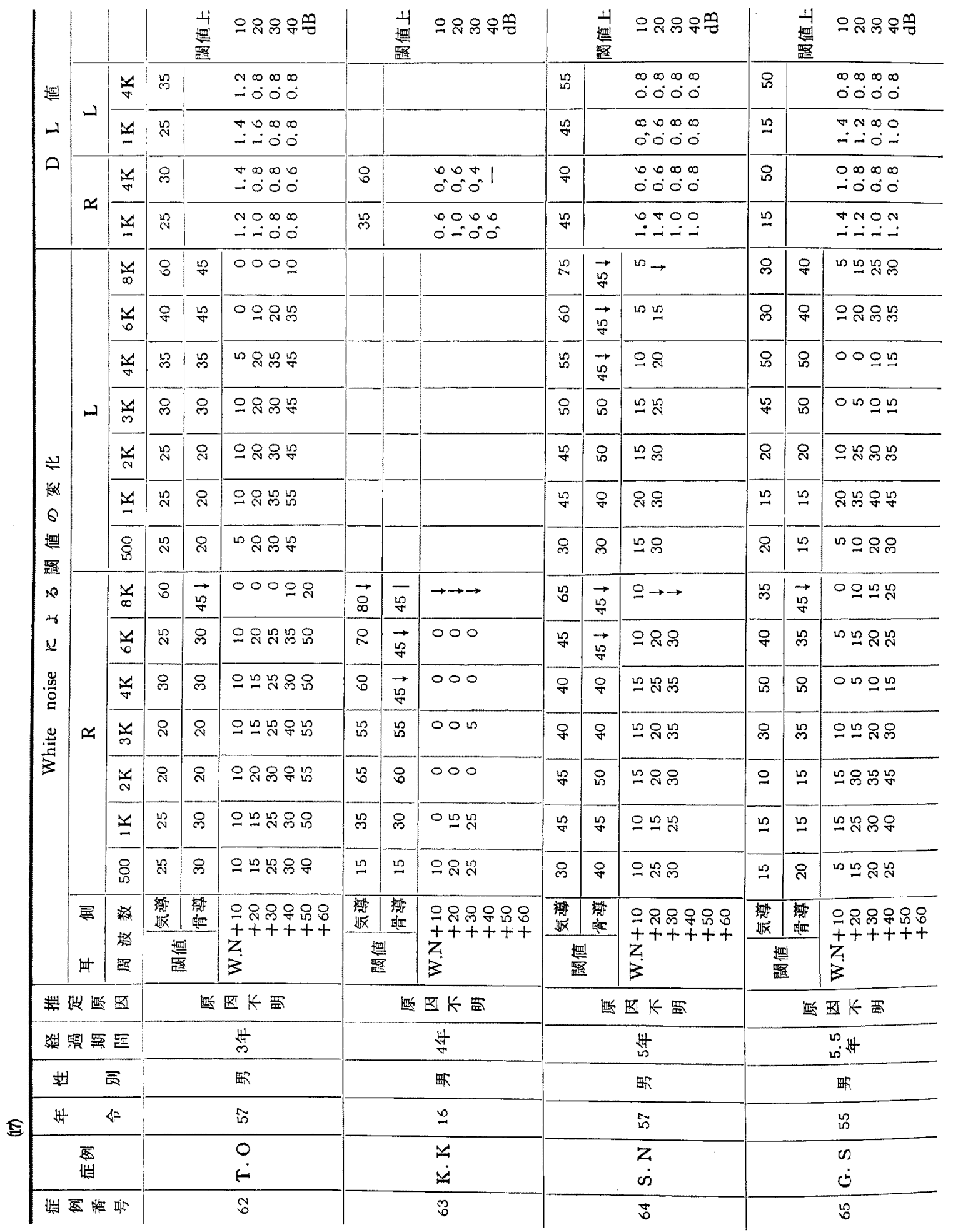




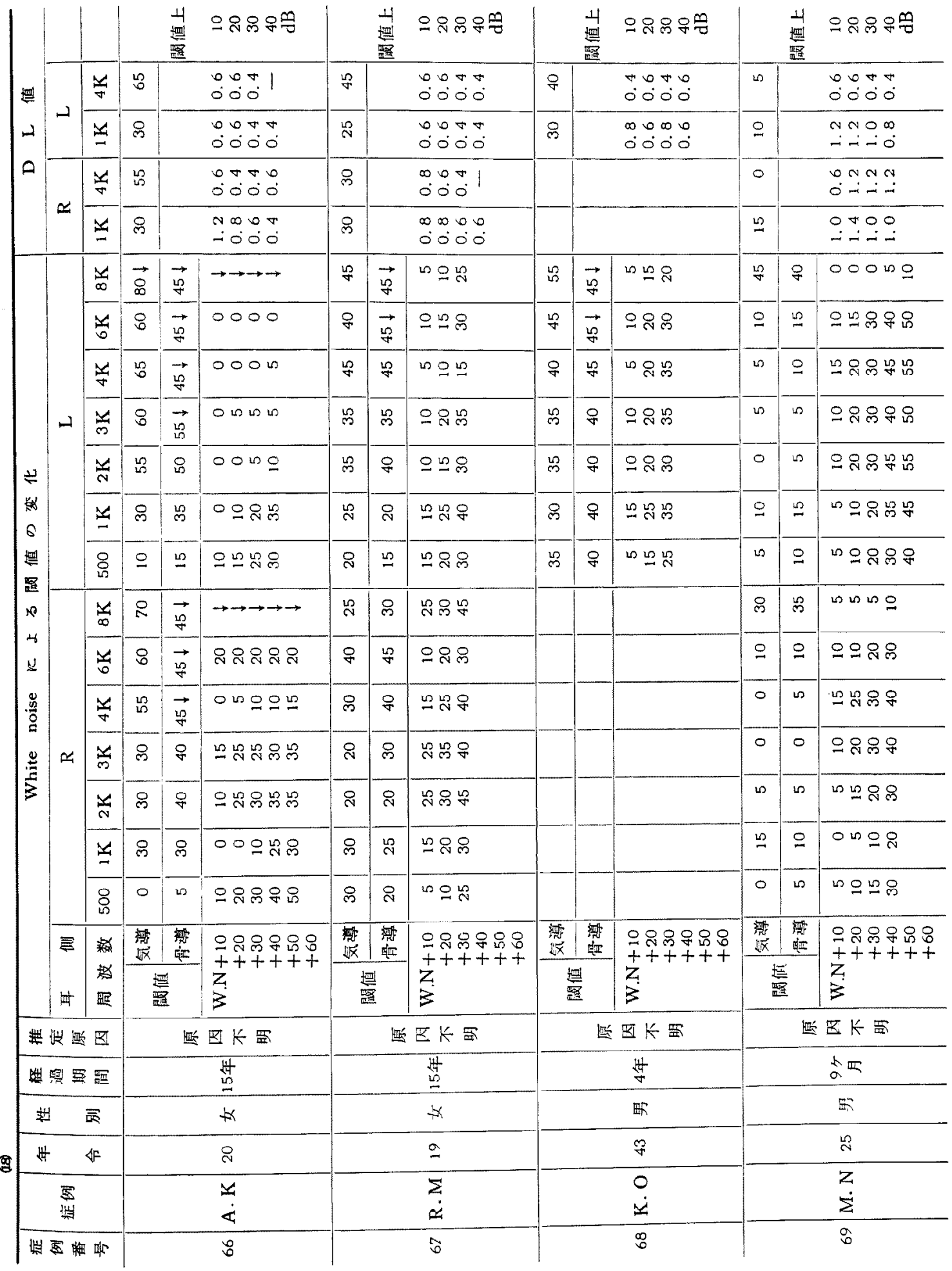




\begin{tabular}{|c|c|c|c|c|c|c|c|c|c|c|c|c|c|c|}
\hline \multirow{5}{*}{$\begin{array}{l}\text { 地 } \\
\sim\end{array}$} & \multirow{3}{*}{$\omega$} & & \multicolumn{3}{|r|}{ 융욤ㅁㅁ } & \multicolumn{3}{|c|}{ 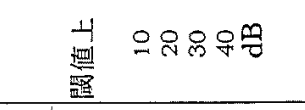 } & \multicolumn{3}{|r|}{ 읏요암ㅁㅁ } & \multicolumn{2}{|c|}{ 拉 } & 옹요암묨 \\
\hline & & 茨 & 움 & & 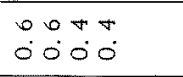 & 우 & & $\begin{array}{lll}\infty & \infty & \infty \\
0 & 0 & 0 \\
0 & 0 & 1\end{array}$ & 户 & & $\begin{array}{l}0 \times 0 \% \\
-1 \\
-10\end{array}$ & $\underline{-2}$ & & $\begin{array}{l}N 000 \\
-10 \% \\
-10\end{array}$ \\
\hline & & 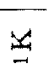 & 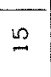 & & $\begin{array}{l}\sim \sim 0 \\
\sim-\end{array}$ & $\stackrel{\sim}{\sim}$ & & 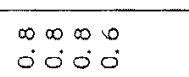 & 尺े & & $\begin{array}{l}00 \infty \\
-\therefore 00\end{array}$ & $\stackrel{2}{2}$ & & $\begin{array}{l}0000 \\
-1-00\end{array}$ \\
\hline & \multirow{2}{*}{$\approx$} & 总 & $\stackrel{2}{-2}$ & & $\begin{array}{l}000 N \\
000 \\
000\end{array}$ & 号 & & $\begin{array}{llll}0 & 0 & 0 & 1 \\
0 & 0 & 0 & 0 \\
0\end{array}$ & 요 & & 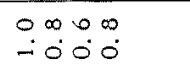 & ㅇ & & 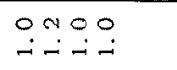 \\
\hline & & $\underline{x}$ & 9 & & 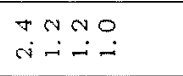 & 8 & & $\begin{array}{l}00000 \\
0: 00 \\
0\end{array}$ & 음 & & $\begin{array}{l}0000 \\
-000 \\
-0\end{array}$ & 8 & & 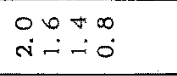 \\
\hline \multirow{7}{*}{\multicolumn{2}{|c|}{ 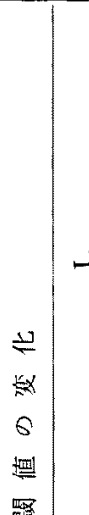 }} & $\frac{1}{\infty}$ & $\stackrel{2}{7}$ & $\stackrel{9}{7}$ & 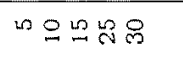 & 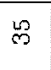 & 㟧 & 오용ㅇㅁ & 웅 & $\vec{b}$ & OO & $\stackrel{m}{m}$ & 우 & ○ం유 \\
\hline & & 舲 & 암 & p & ㅁㅇㅇㅇㅛ & 윰 & 品 & 응요 & 8 & $\stackrel{m}{m}$ & 요욤ㅇ & ஜ & $\stackrel{\sim}{\sim}$ & ம요ㅇㅛㅛ용 \\
\hline & & $\frac{4}{T}$ & ㅇ & 움 & ㅁ요욤요 & 웁 & q & 늠요요 & $\stackrel{\rho}{\circ}$ & $m$ & 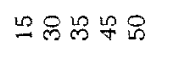 & $\stackrel{2}{2}$ & 우 & 음유옹요맹 \\
\hline & & 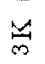 & $\stackrel{\leftrightarrow}{\sim}$ & 8 & 욤유욤움 & 육 & q & 으느용 & $\stackrel{\llcorner}{\sim}$ & ஓ & 음용문 & 9 & 은 & 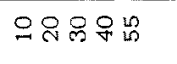 \\
\hline & & 崔 & $\stackrel{2}{=}$ & 8ิ & 上므ㅇㅛㅛㅇㅛ & $\stackrel{\sim}{\sim}$ & $\stackrel{u}{\mathrm{~N}}$ & 느용우 & $\stackrel{2}{\sim}$ & $\stackrel{p}{\sim}$ & 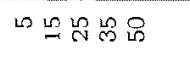 & 8 & 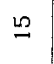 & 느ㅁㅕㅗ용 \\
\hline & & $\underline{=}$ & $\stackrel{2}{\square}$ & 2 & ம몸워 & 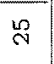 & 品 & 는 융요 & ஜิ & $\stackrel{i}{~}$ & n용ㅇㅇㅇㅁ 우 & $\underline{\sim}$ & $\stackrel{2}{2}$ & 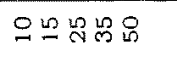 \\
\hline & & 8 & 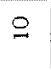 & $\stackrel{2}{2}$ & 几 & 움 & 8 & $n$ 으뭉 & $\stackrel{n}{a}$ & 오 & ㅁㅇ묘묘 & 요 & 운 & 으늠로용우 \\
\hline \multirow{9}{*}{ 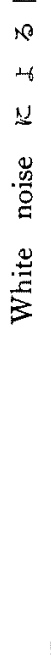 } & \multirow{7}{*}{ 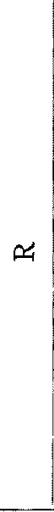 } & $\frac{1}{\infty}$ & 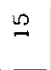 & ฉิ & 옴品东品 & 品 & $\vec{q}$ & 000 & $\stackrel{\circ}{\circ}$ & 운 & ూ & 윰 & 우 & 이묨요 \\
\hline & & 4 & 8 & 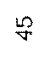 & O & 8 & $\vec{\square}$ & $0\llcorner 0$ & $\stackrel{2}{2}$ & 8 & 曲品品卓 & 8 & $\stackrel{\mathscr{N}}{\sim}$ & w용요용 \\
\hline & & 岀 & $\cong$ & 8 & 요요욤요 & 吕 & $\mathscr{q}$ & ம๐ & 요 & 8 & 늠요요욱 & ๑ิ & ฉి & 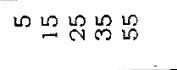 \\
\hline & & 空 & $\stackrel{2}{=}$ & 요 & 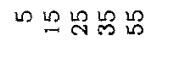 & 安 & 虽 & n으용 & $\stackrel{\mathscr{N}}{N}$ & $\stackrel{8}{5}$ & ద느묘 & $\subseteq$ & $\underline{-2}$ & 으옹용ㅇㅁ용 \\
\hline & & $\frac{x}{N}$ & $\because$ & 9 & ம응 只品品 & 암 & \& & 电只 & $\cong$ & $\varrho$ & 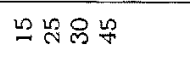 & $\stackrel{20}{2}$ & $\stackrel{2}{\longrightarrow}$ & ே믁융용 \\
\hline & & $\underline{-1}$ & 음 & 9 & 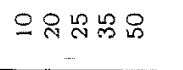 & 웅 & 8 & $\curvearrowleft ㅇ ㅡ$ & $\cong$ & 음 & 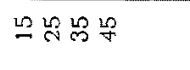 & $\stackrel{8}{8}$ & $\stackrel{\mathscr{L}}{\sim}$ & 으용욤ㄴㅁㄴ \\
\hline & & 8 & $\stackrel{0}{-}$ & in & 늑용ㅇㅁㅇㅁㅇ & 8 & 识 & $n O$ & \& & 은 & 109 & \& & 요 & ○に上只邑 \\
\hline & \multirow[t]{2}{*}{ ᄅ } & \multirow{2}{*}{ 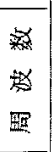 } & 瀷 & \multirow{2}{*}{ 渐 } & \multirow{2}{*}{ 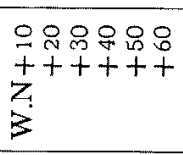 } & 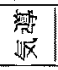 & 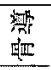 & \multirow{2}{*}{$\begin{array}{l}\text { 용요요요요 } \\
+++++t \\
z \\
3\end{array}$} & 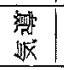 & 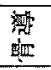 & \multirow{2}{*}{$\begin{array}{l}988908 \\
++++++ \\
z \\
3\end{array}$} & 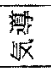 & $\begin{array}{l}\text { 就 } \\
\text { 监 } \\
\end{array}$ & \multirow{2}{*}{ 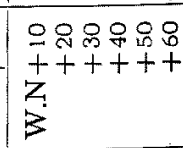 } \\
\hline & & & 造 & & & 塂 & & & 㩊 & & & 㮛 & & \\
\hline \multicolumn{3}{|c|}{ 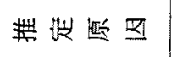 } & \multicolumn{3}{|c|}{ 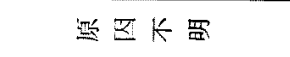 } & \multicolumn{3}{|c|}{ 近黑长罡 } & \multicolumn{3}{|c|}{ 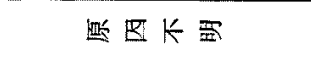 } & \multicolumn{3}{|c|}{ 此区益 } \\
\hline \multicolumn{3}{|c|}{ 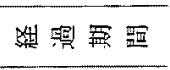 } & \multicolumn{3}{|c|}{$\begin{array}{l}5 \\
-25 \\
\end{array}$} & \multicolumn{3}{|r|}{$\frac{14}{5}$} & & & 占孟 & & & 妾 \\
\hline 荘 & & E⿰ & & & 酐 & & & $\not x$ & & & $\$$ & & & 㽖 \\
\hline$\frac{4}{4}$ & & & & & $\stackrel{\infty}{\pi}$ & & & 옹 & & & F & & & g \\
\hline & 蔮 & & & & $\begin{array}{l}\infty \\
\Sigma\end{array}$ & & & $\begin{array}{l}4 \\
-4\end{array}$ & & & $\underset{x}{x}$ & & & $\begin{array}{l}\text { 吉 } \\
\text { 㝎 }\end{array}$ \\
\hline 湈 & 臣媵 & & & & $R$ & & & $\vec{Z}$ & & & $\mathrm{~N}$ & & & 8 \\
\hline
\end{tabular}




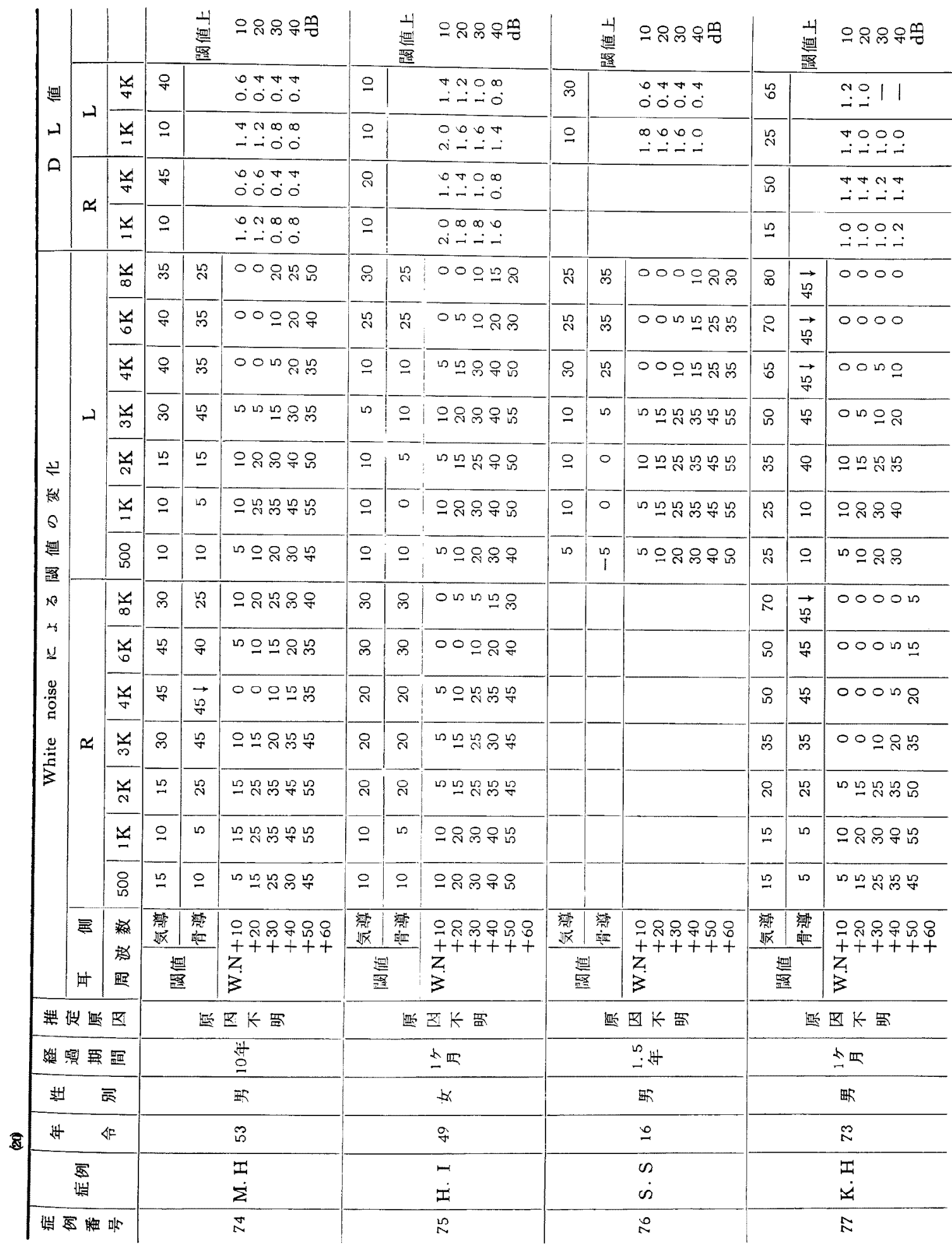




\begin{tabular}{|c|c|c|c|c|c|c|c|c|c|c|c|c|c|}
\hline & & & 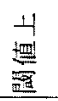 & 응ㅇㅇㅇㅇㅁㅇㅢ & & 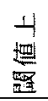 & 응ㅇㅁㅇㅇㅁㅇㅠ & & 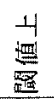 & 으용응ㅇㅁ웜 & & 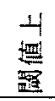 & 응요 웅를 \\
\hline \multirow{2}{*}{ - } & $\frac{1}{7}$ & 8 & & $\begin{array}{l}0000 \\
-000 \\
-000\end{array}$ & 品 & & 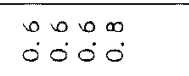 & 움 & & $\begin{array}{l}\nabla \nabla \nabla \\
000 \\
00\end{array}$ & & & \\
\hline & $\because$ & $\mathscr{2}$ & & $\begin{array}{l}0 \infty \infty \infty \\
-000 \\
-00\end{array}$ & 0 & & $\begin{array}{l}\infty \circ \infty 0 \\
0-0 \\
0\end{array}$ & $\stackrel{20}{2}$ & & $\begin{array}{l}0 \forall+N \\
0000\end{array}$ & & & \\
\hline \multirow{2}{*}{ 姃 } & 学 & $尺$ & & 0.111 & $\omega$ & & $\begin{array}{l}\infty 000 \\
0-0 \\
0\end{array}$ & 웁 & & $\begin{array}{l}\nabla \nabla \nabla \\
000\end{array}$ & $\mathscr{m}$ & & $\begin{array}{l}0000 \\
-1000 \\
-100\end{array}$ \\
\hline & $\stackrel{4}{=}$ & 0 & & $\begin{array}{l}0 \sim 0 \infty \\
\sim \sim \sim \\
\end{array}$ & 0 & & $\begin{array}{l}\because 0 \\
\because-0 \\
-10 \\
\end{array}$ & $\ddot{m}$ & & $\begin{array}{l}0 \pi N \sigma \\
0000\end{array}$ & 10 & & $\begin{array}{l}0 \infty \infty 0 \\
-000 \\
-00\end{array}$ \\
\hline \multirow{7}{*}{ 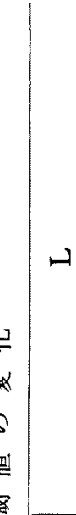 } & $\infty$ & 品 & $\vec{b}$ & $\circ \rightarrow \rightarrow \rightarrow \rightarrow \rightarrow$ & $R$ & $\vec{b}$ & 이요옹 & 윰 & $\stackrel{9}{9}$ & 요유 & & & \\
\hline & 站 & $\stackrel{R}{R}$ & $\vec{b}$ & $0000 \mathrm{n}$ & 8 & 吊 & 으는 & 8 & \& & $0 \circ \omega n \circ$ & & & \\
\hline & $\frac{4}{\sigma}$ & 8 & $\vec{b}$ & ๒음요 & 8 & है & م & 우 & 品 & ০০유요 & & & \\
\hline & $\frac{1}{m}$ & q & $\vec{\circ}$ & 으모ำ 只 & 움 & 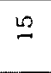 & טמט מט & ᄋ్ల & 운 & 요욤ำ & & & \\
\hline & $\frac{s}{c}$ & ฉి & $\stackrel{\infty}{\curvearrowleft}$ & 응요욤뇨 군 & $\circ$ & L & 吅只品告 & $\stackrel{\leftrightarrow}{\mathrm{N}}$ & $\stackrel{m}{m}$ & 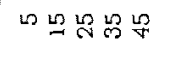 & & & \\
\hline & $\triangleq$ & $\stackrel{\circ}{\sim}$ & 0 & 융용ㅇㅁㅁㅁㅁ & $\circ$ & 0 & 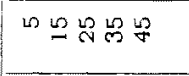 & $\stackrel{m}{\rho}$ & $\ddot{m}$ & 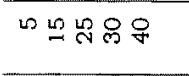 & & & \\
\hline & 8 & $n$ & $n$ & 응요용요음 & 0 & 0 & ம으놈오욨 & $\stackrel{\sim}{N}$ & 옹 & 느요용 品 & & & \\
\hline \multirow{7}{*}{$\infty$} & $\infty$ & $R$ & $\vec{b}$ & 00010 & 号 & 果 & 00001 & $\stackrel{n}{\nabla}$ & $\vec{b}$ & ๒ & $\mathscr{8}$ & : & $00000 \mathrm{n}$ \\
\hline & 幽 & $?$ & $\overrightarrow{3}$ & 00000 & $\stackrel{\mathscr{N}}{\mathrm{N}}$ & $\stackrel{\llcorner}{\sim}$ & 00010 & นึ. & $\vec{g}$ & ○ం & $\stackrel{4}{q}$ & $\stackrel{\&}{q}$ & $0000 \mathrm{n}$ \\
\hline & $y$ & $R$ & $\vec{q}$ & 00000 & is & 음 & 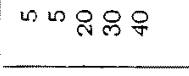 & 우 & 占 & レレㅡㅇㅇㅇㅇㅠ & $\stackrel{n}{p}$ & $\stackrel{p}{m}$ & 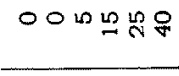 \\
\hline & 峁 & 욤 & $\overrightarrow{\text { 品 }}$ & תמ מט 000 & 0 & 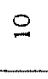 & 늠只号号 & 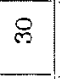 & $\stackrel{n}{7}$ & 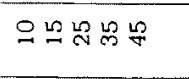 & i & 오 & 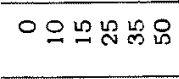 \\
\hline & $\frac{1}{4}$ & 유 & 요 & 늠ㅇㅇㅇㅁㅇ & $\circ$ & L & 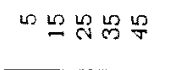 & ㅇ & $\mathscr{\wp}$ & 음믐몽우용 & 8 & 유 & 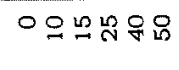 \\
\hline & 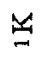 & $\circ$ & 0 & 몽品号员 & 0 & 0 & 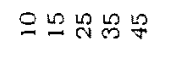 & $\stackrel{n}{m}$ & 邑 & 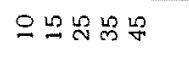 & $\infty$ & in & 응용ㅇㅇ용ㅇㅇ \\
\hline & 8 & $\infty$ & م & 음유암 & 0 & 0 & 以 & 8 & $\stackrel{2}{ล}$ & 으몽요유욤 & $\supseteq$ & $\cong$ & 으용뭉요 \\
\hline \multirow[t]{2}{*}{ 㕄 } & 棌 & $\begin{array}{l}\text { 瑯 } \\
\text { 这 }\end{array}$ & $\begin{array}{l}\text { 慗 } \\
\text { 垔 } \\
\end{array}$ & \multirow{2}{*}{$\begin{array}{l}0.8089808 \\
+1+++1 \\
z \\
3\end{array}$} & $\begin{array}{l}\text { 排 } \\
\text { 这 }\end{array}$ & 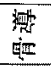 & \multirow{2}{*}{$\begin{array}{l}\text { 응ㅇㅇㅇㅇㅇㅇㅇ } \\
+t+t+1 \\
z \\
3\end{array}$} & $\begin{array}{l}\text { 霹 } \\
\sqrt[4]{x}\end{array}$ & \multirow{2}{*}{ 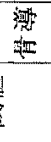 } & \multirow{2}{*}{$\begin{array}{l}\text { 융용ㅇㅇㅇㅇㅇ } \\
++++++ \\
z \\
3\end{array}$} & 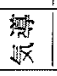 & 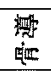 & \multirow{2}{*}{ 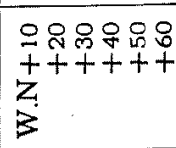 } \\
\hline & 㽢 & 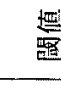 & & & 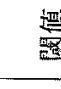 & & & 地 & & & 擼 & & \\
\hline \multicolumn{2}{|c|}{ 曹技此四 } & \multicolumn{3}{|c|}{ 政 $\mathbb{K}$ 囬 } & \multicolumn{3}{|c|}{ 迎 叉长囬 } & \multicolumn{3}{|c|}{ 欧区K置 } & \multicolumn{3}{|c|}{ 迎区长置 } \\
\hline \multicolumn{2}{|c|}{ 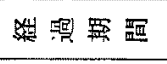 } & \multicolumn{3}{|c|}{ 供 } & \multicolumn{3}{|r|}{$\stackrel{4}{9}$} & \multicolumn{3}{|r|}{ 类 } & \multicolumn{3}{|r|}{ 点留 } \\
\hline$\#$ & 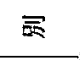 & \multicolumn{3}{|r|}{$E$} & \multicolumn{3}{|r|}{$H$} & \multicolumn{3}{|r|}{$+x$} & & & $\$ x$ \\
\hline 4 & 红 & & & 另 & & & $\stackrel{\sim}{\sim}$ & & & $\stackrel{\infty}{\sim}$ & & & $\infty$ \\
\hline 亟 & & & & $\dot{4}$ & & & $z$ & & & $\begin{array}{l}I \\
\dot{\Sigma}\end{array}$ & & & $\begin{array}{l}Z \\
\xi\end{array}$ \\
\hline 齿 & & & & $\stackrel{\infty}{\sim}$ & & & 2 & & & $\infty$ & & & $\vec{\infty}$ \\
\hline
\end{tabular}




\begin{tabular}{|c|c|c|c|c|c|c|c|c|c|c|c|c|c|}
\hline \multirow{3}{*}{ دـ } & & \multicolumn{3}{|c|}{$\begin{array}{l}4 \\
\text { 覆 } \\
\end{array}$} & \multicolumn{3}{|c|}{ 嗃 } & \multicolumn{3}{|c|}{ 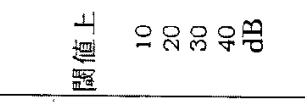 } & \multicolumn{2}{|r|}{ 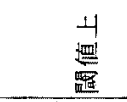 } & \multirow[t]{2}{*}{ 옷요묵 } \\
\hline & $\underset{7}{*}$ & 员 & & 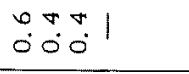 & 8 & & $\begin{array}{l}00000 \\
-100 \\
-10 \\
-10\end{array}$ & $\stackrel{\leftrightarrow}{\sim}$ & & $\begin{array}{lll}\infty & \infty & \infty \\
0 & \infty \\
0 & 0 & 0 \\
0 & 0 & 0 \\
\end{array}$ & $\mathscr{2}$ & & \\
\hline & $\underline{-}$ & 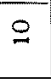 & & $\begin{array}{l}0000 \\
000 \\
00\end{array}$ & $\stackrel{\leftrightarrow}{\sim}$ & & 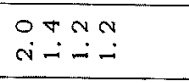 & $\therefore$ & & 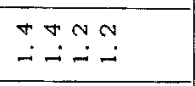 & n & & $\begin{array}{l}0000 \\
0000 \\
00\end{array}$ \\
\hline & 学 & 용 & & $\begin{array}{l}0000 \\
00 \\
0\end{array}$ & & & & i & & $\begin{array}{llll}\infty & 0 & 0 & \infty \\
0 & 0 & 0 & 0 \\
0 & 0 & 0\end{array}$ & 吕 & & \begin{tabular}{lll|}
0 & 0 & $\pi$ \\
0 & 0 & 0
\end{tabular} \\
\hline+ & $\underline{-}$ & $\therefore$ & & $\begin{array}{l}0000 \\
-000 \\
-000 \\
\end{array}$ & & & & $\mathscr{0}$ & & $\begin{array}{l}\infty \infty \infty \infty \\
\infty 00 \\
00 \\
0\end{array}$ & $\stackrel{\sim}{\sim}$ & & 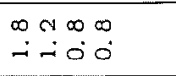 \\
\hline \multirow{7}{*}{ 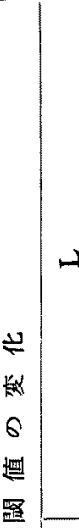 } & $\frac{1}{\infty}$ & 8 & $\vec{q}$ & 0000 م & 邑 & ஜ & O 0 เน็น & $\stackrel{n}{\infty}$ & 운 & 0000 욤묘 & นุ & $\stackrel{n}{m}$ & 000989 \\
\hline & $\frac{1}{0}$ & 8 & $\overrightarrow{\mathrm{g}}$ & 000090 & 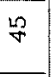 & $\stackrel{\rho}{\rho}$ & $000 \stackrel{\sim}{\sim}$ & 户 & 움 & Oచน & 운 & q & 000102 \\
\hline & 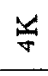 & 吕 & $\vec{g}$ & 000 & \& & ৪ & ㅇㅇㅇ요용 & $\stackrel{\sim}{\sim}$ & 怘 & ○レ只只品 品 & $\mathscr{a}$ & 은 & 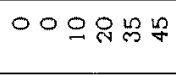 \\
\hline & 学 & $\frac{2}{\square}$ & 음 & 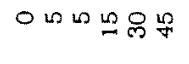 & ळ & $\stackrel{\leftrightarrow}{N}$ & 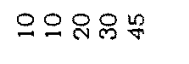 & 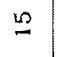 & $\stackrel{\sim}{\sim}$ & "으오욤눈 & 욤 & 오 & 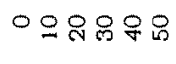 \\
\hline & 救 & $\stackrel{2}{=}$ & $\stackrel{2}{2}$ & 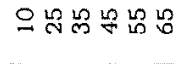 & $\stackrel{\mathscr{N}}{2}$ & $\stackrel{2}{\longrightarrow}$ & 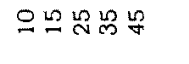 & $\circ$ & $\cong$ & 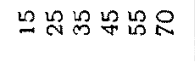 & $\circ$ & 은 & 으옹요우음농 \\
\hline & 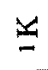 & 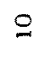 & 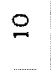 & 느음웅ㅇㅇㅇㅇㅇㅇ & $\stackrel{2}{N}$ & $\stackrel{2}{2}$ & 늑옹옹 & 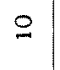 & is & 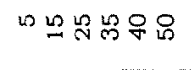 & น & 0 & 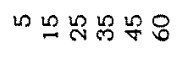 \\
\hline & 品 & $\stackrel{\sim}{\wedge}$ & 8 & ㄴ용요 & $\stackrel{2}{2}$ & & 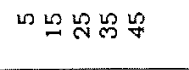 & $\infty$ & 9 & 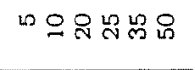 & $\circ$ & 운 & 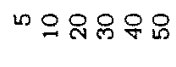 \\
\hline \multirow{7}{*}{$\approx$} & $\frac{1}{\infty}$ & 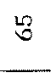 & $\vec{b}$ & 000009 & & & & 卣 & 욕 & 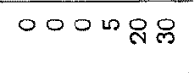 & $\stackrel{2}{2}$ & ๒ & 000000 \\
\hline & 当 & 8 & $\vec{b}$ & 000098 & & & & 움 & $q$ & 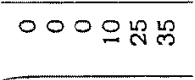 & $\stackrel{2}{N}$ & \& & 000000 \\
\hline & 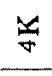 & is & $\vec{w}$ & 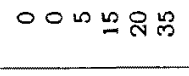 & & & & 요 & లి & 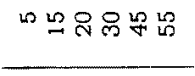 & 吕 & ి్ల & 00009 \\
\hline & है & q & 용 & ㅇㅇ으유씽ㅁㅇㅇ & & & & $\stackrel{\sim}{N}$ & $\stackrel{\wp}{\circ}$ & 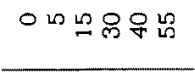 & 趐 & $\stackrel{2}{2}$ & 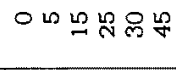 \\
\hline & है & $\stackrel{2}{2}$ & $\stackrel{2}{2}$ & உミ욤요 & & & & 0 & 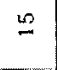 & 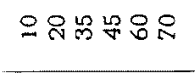 & 은 & $n$ & 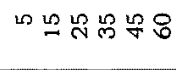 \\
\hline & $\because$ & 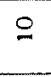 & $n$ & 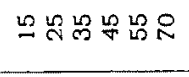 & & & & $\stackrel{2}{\longrightarrow}$ & 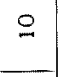 & 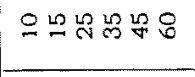 & $\stackrel{2}{2}$ & L & 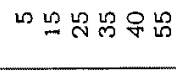 \\
\hline & 움 & $\ddot{\circ}$ & $\stackrel{m}{m}$ & 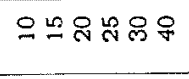 & & & & เo & $\stackrel{9}{9}$ & 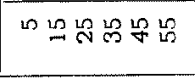 & $\stackrel{2}{-1}$ & $n$ & ம뽀요 \\
\hline \multirow[t]{2}{*}{ ᄅ } & 稀 & 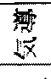 & 政 & 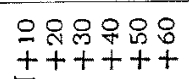 & $\begin{array}{l}\text { 枸 } \\
\text { 这 } \\
\end{array}$ & 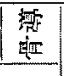 & \multirow{2}{*}{$\begin{array}{l}0889888 \\
++++++ \\
z \\
3\end{array}$} & 洴 & 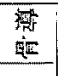 & \multirow{2}{*}{ 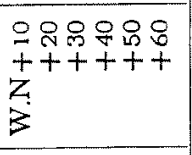 } & | & 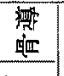 & \multirow{2}{*}{ 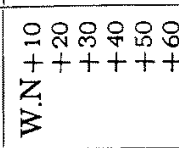 } \\
\hline & 傮 & $t$ & & & 5 & 焉 & & 擐 & & & 地 & 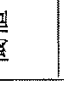 & \\
\hline \multicolumn{2}{|c|}{ 㟽投酒区 } & \multicolumn{3}{|c|}{ 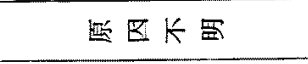 } & \multicolumn{3}{|c|}{ 然长置 } & \multicolumn{3}{|c|}{ 些区K } & \multicolumn{3}{|c|}{ 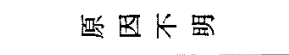 } \\
\hline \multicolumn{2}{|c|}{ 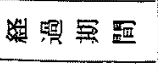 } & \multicolumn{3}{|c|}{$\frac{11}{7}$} & \multicolumn{3}{|c|}{ 眔 } & \multicolumn{3}{|c|}{$\begin{array}{l}\text { 贾 } \\
k\end{array}$} & \multicolumn{3}{|c|}{$\frac{4}{m}$} \\
\hline \multicolumn{2}{|c|}{$\$$} & \multicolumn{3}{|r|}{ 理 } & \multicolumn{3}{|r|}{ 㪘 } & \multicolumn{3}{|r|}{ 㱐 } & & & 䞏 \\
\hline 4 & & & & కే & & & $\vec{b}$ & & & 藏 & & & $\stackrel{2}{=}$ \\
\hline 霜 & & & & $\begin{array}{l}\check{I} \\
\check{\check{L}}\end{array}$ & & & $\begin{array}{l}n \\
\Leftrightarrow\end{array}$ & & & $\dot{m}$ & & & s \\
\hline 宸 8 & 마 & & & $\mathscr{\infty}$ & & & $\mathscr{D}_{\infty}$ & & & $\vec{\Phi}$ & & & $\stackrel{\mathscr{D}}{\infty}$ \\
\hline
\end{tabular}




\begin{tabular}{|c|c|c|c|c|c|c|c|c|}
\hline \multirow{5}{*}{$\begin{array}{l}\text { 国 } \\
\text { - } \\
0\end{array}$} & & & & $\begin{array}{l}4 \\
\text { 逜 } \\
\text { 焉 }\end{array}$ & 응요욤욤 & & $\begin{array}{l}4 \\
\text { 囬 } \\
\end{array}$ & 요용ㅂㅁ \\
\hline & \multirow{2}{*}{$\mapsto$} & $\stackrel{4}{\sigma}$ & 另 & & $\begin{array}{lll}0 & 0 & 0\end{array}$ & 8 & & $\begin{array}{l}\forall \forall \forall \dot{0} \\
\dot{0} \dot{0} \dot{0}\end{array}$ \\
\hline & & 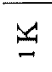 & 0 & & $\begin{array}{l}00 T N \\
000\end{array}$ & $n$ & & $\begin{array}{l}\infty 000 \\
\therefore \therefore-1\end{array}$ \\
\hline & \multirow{2}{*}{ A } & $\frac{4}{\sigma}$ & 육 & & $\begin{array}{l}\forall+\square \\
0000\end{array}$ & 8 & & $\begin{array}{l}0 \forall+4 \\
0000\end{array}$ \\
\hline & & $\cong$ & 0 & & $\begin{array}{l}0000 \\
-0.00\end{array}$ & in & & 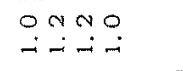 \\
\hline \multirow{16}{*}{ 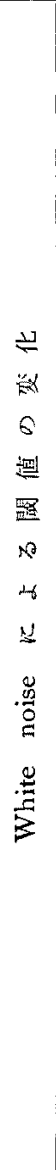 } & \multirow{7}{*}{$\mapsto$} & $\infty$ & 8 & $\stackrel{2}{2}$ & 000988 & 8 & $\vec{q}$ & 000000 \\
\hline & & : & is & 움 & 000010 & 8 & $\vec{g}$ & 0000100 \\
\hline & & $\frac{1}{7}$ & 8 & $\vec{b}$ & 000008 & 8 & $\vec{p}$ & 000000 \\
\hline & & $\frac{4}{m}$ & 8 & 8 & w옹요운 & $\stackrel{P}{\forall}$ & $\stackrel{8}{\square}$ & 000008 \\
\hline & & 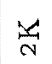 & $\infty$ & 9 & 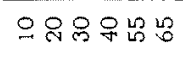 & 옹 & $\stackrel{0}{\sim}$ & w응요암음 \\
\hline & & 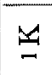 & 0 & 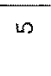 & 농ำ & م & م & 以上ำ \\
\hline & & 8 & is & 음 & 으용요용 & 0 & in & 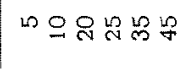 \\
\hline & \multirow{7}{*}{$\sim$} & $\stackrel{\infty}{\infty}$ & 0 & 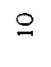 & 응요용ํำ & 8 & $\vec{q}$ & 0000010 \\
\hline & & vo & 윰 & 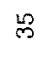 & $000100 \Omega$ & 용 & $\vec{g}$ & 000012 \\
\hline & & 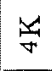 & 움 & $\ddot{q}$ & 응으는 & 은 & $\overrightarrow{\frac{0}{q}}$ & 000088 \\
\hline & & 㲾 & 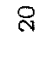 & 禺 & ㄴ요욤ำ & $\stackrel{\leftrightarrow}{\circ}$ & $\stackrel{\text { 농 }}{7}$ & 000요요 \\
\hline & & $\frac{N}{N}$ & 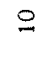 & $\stackrel{20}{\rightarrow}$ & 응오용요맘 & $\cong$ & 20 & แ응용ํำ \\
\hline & & 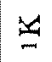 & $\circ$ & $\infty$ & 응용ㅇㅇㅇㅛ & in & 웅 & 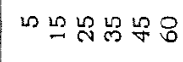 \\
\hline & & 8 & 0 & s & 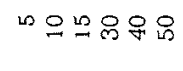 & 10 & 웅 & ๘只里只邑次 \\
\hline & \multirow[t]{2}{*}{ 蛋 } & 林 & 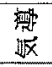 & 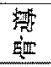 & \multirow{2}{*}{ 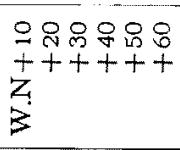 } & $\begin{array}{l}\text { 湾 } \\
\sqrt[1]{x} \\
\end{array}$ & 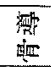 & \multirow{2}{*}{$\begin{array}{l}\text { 용ㅇㅇㅇㅇㅇㅇㅇ } \\
+1+++1 \\
z \\
z\end{array}$} \\
\hline & & $\begin{array}{l}\text { 紫 } \\
\text { 㧽 }\end{array}$ & 热 & & & & & \\
\hline \multicolumn{3}{|c|}{ 投延四 } & \multicolumn{3}{|c|}{ 紫置 } & \multicolumn{3}{|c|}{ 还置 } \\
\hline \multicolumn{3}{|c|}{ 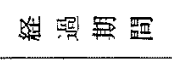 } & & & $\begin{array}{c}4 \\
-4 \\
\end{array}$ & & & 艺 \\
\hline \multicolumn{2}{|c|}{$\#$} & 롲 & \multicolumn{3}{|r|}{ 吠 } & \multicolumn{3}{|r|}{ 旷 } \\
\hline \multicolumn{2}{|c|}{4} & $\langle F$ & \multicolumn{3}{|r|}{$\ddot{ల}$} & \multicolumn{3}{|r|}{$\stackrel{\infty}{+}$} \\
\hline \multicolumn{3}{|c|}{ 蛋 } & \multicolumn{3}{|r|}{$\begin{array}{l}H \\
\dot{H}\end{array}$} & \multicolumn{3}{|r|}{$\ddot{H}$} \\
\hline \multicolumn{3}{|c|}{ 愣亚卟 } & \multicolumn{3}{|c|}{$\infty$} & \multicolumn{3}{|r|}{$\infty$} \\
\hline
\end{tabular}




\section{主要文献}

1) Langenbeck, B.: Hören in Lärm, Zschr. f. Hals-, Ohrenheilk., $30 ; 1,1932$.

2) Palva, T., Goodman, A., and Hirsh, I.J. : critical evaluation of noise audiometry. Laryngoscope, $63 ; 842,1953$.

3) Huizing, H.C.: Die Bestimmung der Regression bei der Gehörprüfung der physikalische, physiologische und psychologische Zusammenhang bei der Gehörprothese. Acta Otolaryng., $30 ; 487,1942$. 4) Langenbeck, B.: Geräuschaudiometrische Diagnostik. Arch für Ohren. heilk., 157 ; 121, 1950. 5) Langenbeck. B.: Geräuschaudiometrische Diagnostik. Arch für Ohrenheilk., $158 ; 458,1950$. 6) Kietz, H.: Erweiterte Audiometrie. Arch. für Ohren-, Nasen, und Kehlkopfheilk., $159 ; 371,1951 . \quad 7)$ Zangemeister, H. E. : Erweiterte Audiometrie. Arch. für Ohren-, Nasen-, und Kehlkopfheilk., $159 ; 380,1951 . \quad$ 8) Fletcher, H., and Munson, W.A.: Relation Between Loudness and Masking, J. A.S. A., $9.1 ; 1937$.

9) Hawkins, J. E. aud Stevens, S.S.; The masking of Pure tones and of speech by white noise, J.A.S.A $22 ; 6,1950$. 立木：雑音に上る純音聴力遮蔽に関する基整的研究，日 耳鼻59；1121，1956.(昭31) 11) 立木：杂音下に於 ける純音聴力について、耳喉，26；201，1954(昭29)

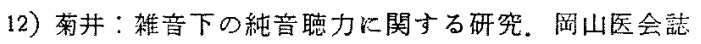
71，8227，1959.(昭34) 13) Wegel, R.E. and Lane, C.E.: The auditory masking of one pure tone by another and its probable relations to the Dynamics of the inner ear. Physical Rew., $24 ; 266,1924$.

Demes, P., and Naunton, R. F.: Masking in PureTone audiometry, Proc, Roy. Soc. Me d., 45 ; 790, 1952. 15) Langenbeck, B. : Die Geräuschaudiometrie als diagnostische Methode, Zschr. f. Laryngol. usw., 29 ; 103, 1950. 16) Riesz R. R. : Differential Intensity Sensitivity of the Ear for Pure Tones, Phy. Rev., 31;867, 1928. 17) Lüscher. E. and Ermanni, A.: Die topisch diagnostische Bedeutung der Unterschiedsschwelle für Ton intensitätsänderungen. Archiv Ohrenusw., 157 ; 158, 1950. 18) Lüscher, E.: The Difference Limen of Intensity Variations of Pure tones and its Diagnostic Significance. J. of Laryng. \& otal., $65 ; 486,1951$. 19) 立木：Recruitment 測定法の㭘 討(2) DL Test について, 耳嘋, 28；163，1956.(昭31)
20) 津川:DL Difference Test k関寸る臨床的研笑, 日耳舆，63；99，1960.(昭35) 21) 小川, 椿：正常者 の正弦波及び矩形波によるDLの閶值、日耳率，59;671， 1956. (昭31) 22) Liden, G. and Nilsson, G. : Differential audiometry, Acta Otol., $38 ; 521,1950$.

23) Hirsh, Palva, Goodman: Differnce Limen and Recruitment, Arch, of Otolaryng., 60; 525, 1954.

24) Jerger, $J$.: A Difference Limen Recruitment and its Diagnostic Significance. Laryngoscope, 62;1316, 1952. 25) Denes, P., and Naunton, R.F.: The clinical Detection of Auditory Recruitment. J. Laryng. \& Otol. $64 ; 375,1950 . \quad 26)$ Jerger, $J .:$ DL Difference Test, Arch. of Otolaryng, 57;490, 1953.27 ) 恩 地：伝音感音障害の鑑別診断法，耳㘈，24；601，1952. (昭27） 28）Leisti, T. J.: Audiometric Studies of Presbyacusis, Acta Otolaryng., 37; 555, 1949.

29) Schuknecht, H. F. : Presbyacusis. Laryngoscope, 65 ; 402, 1955. 30) Döderlein, W.: Über Presbyakusis, Archiv fur Ohrenheilk., $144 ; 295,1938$.

31) Bunch, C. C.: Further observations on age variations in Auditory acuity, Archiv. of otolaryng, 13; 120, 1931. 32) Matzker, J., u. Springborn, E.: Richtungshören u. Lebensalter, Zschr, furLaryng usw., 37 ; 739, 1958. 33) de la Rosee, Untersuchungenüber das normale Hörvemögen inden verschiedenen Lebensaltern unter besonderer Brücksichtigung der Prüfung mit dem Audiometer, Zschr, f. Laryng., 32; 414, 1953. 34) Saxen, A.: inner Ear in Presbyacusis, Acta Otolaryng., $41 ; 213,1952.35)$ Fleischer, $K$. : Histologische u. Audiometrsche Studie Über den alternsbedingten Struktur u. Funktionswandel des Innenohres. Archiv, fur Ohren-, usw., 170; 142, 1956.

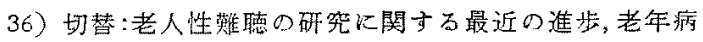
$5 ； 84,1961$.(昭36) 37) 後藤：高年者と聴力, 老年病 2; 46,1958.(昭33) 38) Saltzman, M.:Presbyacusis. Arch. of Otolaryng., 66;67, 1957. 39) Fleischer. $K$, u. Knobloch, $U$.: Die Altersschwerhörigkeit u. Möglichkeiten ihrer medikamentosen Beeinflussung. Zschr.fue Laryng. usw. $36 ; 407,1957$. 40) Pestalozza, G., and Shore, I. : clinical Evaluation of Presbyacusis on the Basis of Different Tests of Auditory function, Laryngoscope $65 ; 136,1955$. 41) Liden, $G$, Nilsson, G., and Anderson, H. : narrow-band mas- 
king with white noise, Acta Otol., $50 ; 116,1958$. 42) Jatho, $K$., $u . K$. Heing, $H$. : Schwellenaudiometrische Untersuchungen über die Progredienz u. Charakteristik der Altersschwerhörigkeit in der verschiedenen Lebensabschnitten, zschr. für Laryng. usw., 38; 72, 1959. 43) Reger, S., u. Kos, C. : Clinical Measurements and implications of recruitment. Ann. Otol., $61 ; 810,1952.44)$ Fowler, E.P.: The recruitment of Loudness. phenomenon, Laryngoscope, $60 ; 680,1950 . \quad 45)$ Palva, T.:Self-Recording Theshold Audiometry and Recruitment, A. M. A. Arch. Otolaryng. 65;591, 1957. 46) Lightfoot, C., Carhart, R., and Gaeth, J. H.: Masking of Impaired Ears by Noise, J. of Speech Dis., 21 ; 56, 1956.

47) Portmann, M., and Portmann, C. : Clinical Audiometry, C. C. Thomas, Springfiled, English ed., 1961. 48) Yantis, P. A.: Locus of the Lesion in Recruiting Ear, A.M.A. Arch. Otolaryng. 62;625. 1955. 49) Langenbeck, B.: Die Geräuschaudiometrie als diagnostische Methode,"Zschr. für Laryng. usw., 29;
470, 1950. 50) Palva, T.: Recruitment and Perstimulatory Fatigue in Diagnosis, J. Otolaryng., 75 ; $216,1961$.

稿を終るに臨み，終始御䈍篤なる御指導及び御校 阅を睗つた恩師後藤修二教援に心から感謝すると共 に，終始衔助言を頂いた三宅助教嗳，滝本講師恶び に梅垣昭一博士に謝意を表します。

本論文の要旨は日本耳率咽喉科学会東海地方会, 第167回（33.9.28)，168回 (33.11.23)，169回 (34. 1.25), 171 回 (34.5.31), 172 回 (34.7.26), 185回 (36.9.10), 186回 (36.11.19) 例会, 中部地方会, 第9回例会 (36.9.23) 飞括いて発表;

本論文の要旨は第5 回日本オージオロジー学会 (昭和35年11月3日). 第6回日本オージオロジー学 会（昭和37年 1 月26日）に拈いて発表. 日本耳卑㸶 喉科学会会報第70巻12号（昭和42年12月）に揭捕予 它.

（原稿受付 昭和42.8.3日） 